\title{
ADVANCEMENTS OF OPERATIONAL OCEANOGRAPHY IN THE BALTIC SEA
}

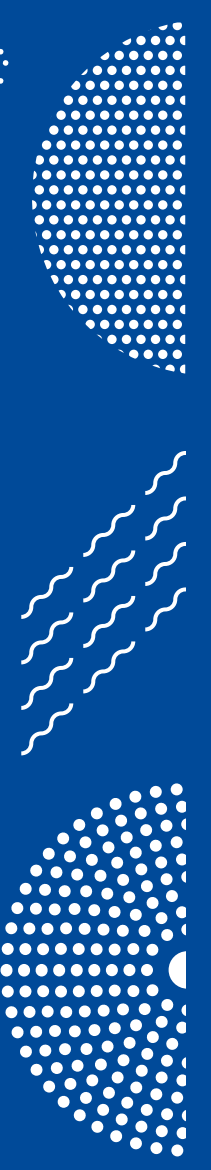

PETRA ROIHA 



\title{
Advancements of operational oceanography in the Baltic Sea
}

\author{
Petra Roiha
}

A doctoral dissertation completed for the degree of Doctor of Science (Technology) to be defended, with the permission of the Aalto University School of Engineering, at a public examination held at the lecture hall A2 of the school on 20 December 2019 at 12. 
Prof. Harri Koivusalo, Aalto University, Finland

Thesis advisor

Dr Laura Tuomi, Finnish Meteorological Institute, Finland

\section{Preliminary examiners}

Prof. Dr Markus Meier, Leibniz-Institute for Baltic Sea Research (IOW), Germany

Prof. Petteri Uotila, University of Helsinki, Finland

\section{Opponent}

Prof. Dr Markus Meier, Leibniz-Institute for Baltic Sea Research (IOW), Germany

(C) 2019 Petra Roiha

ISBN 978-952-60-8848-8 (printed)

ISBN 978-952-60-8849-5 (pdf)

ISSN 1799-4934 (printed)

ISSN 1799-4942 (pdf)

http://urn.fi/URN:ISBN:978-952-60-8849-5
ISBN (paperback): 978-952-336-088-4

ISBN (pdf): 978-952-336-089-1

ISSN: 0782-6117

https://doi.org./10.35614/isbn.9789523360891

Images: [Cover] Observing the Sea of Numerics (2019)

Unigrafia Oy

Helsinki 2019

Finland 
Author

Petra Roiha

Name of the doctoral dissertation

Advancements of operational oceanography in the Baltic Sea

\begin{tabular}{|c|c|}
\hline \multicolumn{2}{|l|}{ Unit Department of Built Environment } \\
\hline Series Aalto University publication series DOCTORAL DISSERTATI & $21 / 2019$ \\
\hline \multicolumn{2}{|l|}{ Field of research Water and environmental engineering } \\
\hline Manuscript submitted 13 May 2019 & e 20 December 2019 \\
\hline \multicolumn{2}{|l|}{ Permission for public defence granted (date) 28 October 2019} \\
\hline$\bigotimes$ Article dissertation & Essay dissertation \\
\hline
\end{tabular}

Abstract

Managing the sea environment is a complicated interdisciplinary task. To understand changes in the sea, knowledge of the present state is essential. Many variables are monitored constantly, and long historical data sets exist. However, the spatial and temporal data coverage varies widely over the Baltic Sea. The preparation for the emerging circumstances demands the ability to forecast the future marine conditions. Thus, improved modelling and forecasting systems are needed.

In this thesis, methods were developed to 1) understand the present state of the sea and 2) predict future conditions. The study areas were the Bothnian Sea and the Eastern Gotland Basin.

Argo floats are a common tool in the oceans, but so far they have not been used in shallow marginal seas, such as the Baltic Sea. The autonomous measurement device brings possibilities to fill the gaps in the existing observation network (e.g. research vessels, moorings) as well as to enable new scientific experiments.

To better understand the present state of the Northern Baltic Sea, methods were developed using the Argo floats. The salinity, temperature and GPS data collected with these floats from the area is analysed in this thesis for the first time and its applicability for studying the different physical phenomena, such as currents at the float diving depth and wind induced mixing, are evaluated.

The usability of Argo data was compared with the ship-borne CTD data. Due to the higher frequency of the Argo data, the seasonal variations can be studied in detail with this method. However, the spatial coverage of the Argo data is not as good as the CTD data collected with a research vessel due to the fact that the floats only operate near the deep areas of the Baltic Sea.

To be able to predict the future conditions of the Baltic Sea, monthly ensemble forecasting system was developed. A 3D biogeochemical model was forced with monthly ensembles of the atmospheric forcing and the results were applied to forecast upwelling events and harmful algal blooms.

The monthly ensemble forecasts for upwelling events were evaluated. The result was that the upwelling events could be forecasted on a weekly scale. This enables, for example, better planning of the scientific study of upwelling events or the improvement of local-scale weather forecasts. The same probability-based ensemble prediction system was used to produce harmful algal bloom forecasts. The forecasts showed the effects of the weather scenarios on marine biogeochemistry.

In the future, it will be possible to interconnect the observations and forecasts better than before. The more dense observations can be used to improve the computational methods, for example, by assimilation. The probability-based forecasts can help, for example, to mitigate the environmental risks.

Keywords operational oceanography, Baltic Sea, Argo, ensemble forecasting, observation, hydrography, harmful algal bloom, upwelling

\begin{tabular}{lc}
\hline ISBN (printed) $978-952-60-8848-8$ & ISBN (pdf) $978-952-60-8849-5$ \\
\hline ISSN (printed) $1799-4934$ & ISSN (pdf) $1799-4942$ \\
\hline Location of publisher Helsinki & Location of printing Helsinki Year 2019 \\
\hline Pages 165 & urn http://urn.fi/URN:ISBN:978-952-60-8849-5 \\
\hline
\end{tabular}



Tekijä

Petra Roiha

Väitöskirjan nimi

Operatiivisen oseanografian edistysaskeleita Itämerellä

\begin{tabular}{lr}
\hline Julkaisija Insinööritieteiden korkeakoulu \\
\hline \multicolumn{2}{l}{ Yksikkö Rakennetun ympäristön laitos } \\
\hline Sarja Aalto University publication series DOCTORAL DISSERTATIONS 221/2019 \\
\hline \multicolumn{2}{l}{ Tutkimusala Vesi- ja ympäristötekniikka } \\
\hline Käsikirjoituksen pvm 13.05 .2019 & Väitöspäivä 20.12.2019 \\
\hline Väittelyluvan myöntämispäivä 28.10 .2019 & Kieli Englanti \\
\hline$\square$ Monografia $\quad \square$ Artikkeliväitöskirja & $\square$ Esseeväitöskirja \\
\hline
\end{tabular}

\section{Tiivistelmä}

Meren ilmiöiden tuntemus ja sitä kautta niiden tutkimus, hoito ja kestävä käyttö perustuvat saatavilla olevaan tietoon meren tilasta. Monia meren ympäristömuuttujia mitataan säännöllisesti ja joistain on olemassa jopa pitkiä historiallisia aikasarjoja, mutta aineiston alueellinen ja ajallinen kattavuus vaihtelee suuresti. Myös monet meressä tapahtuvat fysikaaliset, kemialliset ja biologiset prosessit vaikuttavat toisiinsa ja niiden mittakaavat vaihtelevat. Meren nykytilan tuntemuksen lisäksi on kyettävä ennakoimaan tulevia olosuhteita, jotta niihin voidaan varautua.Tässä työssä kehitettiin menetelmiä, joilla voidaan 1) tutkia Itämeren nykytilaa ja 2) ennustaa sen tulevaa tilaa.

Pohjoisen Itämeren nykytilan analyysiä varten havaintoaineistoa on kerätty vapaasti ajelehtivilla Argo-poijuilla. Niiden keräämää suolaisuus-, lämpötila- ja sijaintiaineistoja analysoitiin tässä työssä ensimmäistä kertaa ja niiden soveltuvuutta arvioitiin erilaisten ilmiöiden, kuten ajelehtimissyvyyden virtausten ja tuulen aiheuttaman sekoittumisen tutkimukseen.

Itämeren tulevan tilan ennustamiseen kehitettiin kuukausiparviennustemenetelmä, jossa kolmiulotteista biogeokemiallista merimallia ajettiin ilmakehäennusteparven avulla ja tuotettujen parviennusteiden soveltuvuutta arvioitiin kumpuamisten ja sinileväkukintojen ennustamiseen.

Argo-poijuja voidaan käyttää sellaisilla merialueilla ja olosuhteissa, joissa esimerkiksi laivahavaintojen tai kiinteiden ankkurointien käyttäminen on syystä tai toisesta hankalaa. Poijujen profilointitiheyttä voidaan säädellä aikavälillä muutamista tunneista viikkoihin, riippuen siitä millaisen mittaluokan ilmiöitä halutaan havainnoida. Saatua dataa verrattiin tutkimusaluksilta mitattuihin CTD-havaintoihin ja huomattiin että Argo-poijut mahdollistavat vuodenaikaisvaihteluiden tarkemman analyysin. Toisaalta niiden alueellinen kattavuus oli heikompi kuin esimerkiksi tutkimusalusten. Argo-poijujen avulla on myös mahdollista kerätä dataa poijujen liikkeistä sukellussyvyydellä.

Kuukausiparviennusteiden ennustepituutta ja ennusteiden osuvuutta arvioitiin kumpuamisten ennustamisessa Selkämerellä. Havaittiin, että kumpuamisia voidaan ennustaa tällä menetelmällä noin pari viikkoa etukäteen. Tämä mahdollistaa esimerkiksi kumpuamistutkimusten paremman suunnittelun. Samalla parviennustemenetelmää kehitettiin pidemmälle tuottamalla myös sinileväennusteita ja havaittiin, että nämä soveltuvat ennustamaan sinileväkukintojen todennäköisyyttä.

Tulevaisuudessa näitä havaintoja ja ennusteita voidaan soveltaa entistä paremmin. Havaintoja voidaan käyttää laskennallisten työkalujen parantamiseen, esimerkiksi assimiloimalla mittausaineistoa malleihin. Ennusteita voidaan käyttää havaintoverkoston ja in-situ tutkimusten optimointiin ja ympäristöriskien hallintaan.

Avainsanat operatiivinen oseanografia, Itämeri, Argo, parviennusteet, hydrografia, sinileväkukinta, kumpuaminen

\begin{tabular}{|c|c|c|}
\hline ISBN (painettu) 978-952-60 & ISBN (pc & $0-8849-5$ \\
\hline ISSN (painettu) 1799-4934 & ISSN (p) & \\
\hline Julkaisupaikka Helsinki & Painopaikka Helsinki & Vuosi 2019 \\
\hline
\end{tabular}





\section{Acknowledgements}

I would like to express my great appreciation to my former and present supervisors and advisors: Prof. Tuomo Karvonen, Prof. Pertti Vakkilainen, Prof. Harri Koivusalo, Teemu Kokkonen and Laura Tuomi for their constructive suggestions and advice during this project.

My superiors at the Finnish Meteorological Institute (FMI) have always been supportive on my scientific pursuits. I am grateful to Tapani Stipa, Jari Haapala and Laura Tuomi for many interesting research projects I have been able to take part. I want to also thank Maa- ja Vesitekniikan tuki ry. and Sven Hallin Research Foundation sr. for financial support in the beginning of my $\mathrm{PhD}$ studies.

This work could not have been completed without insightful pre-examiners: Prof. Markus Meier and Prof. Petteri Uotila, whose comments were helpful and their enthusiasm for the topic was inspirational. I also want to thank Prof. Meier for accepting the invitation to act as my opponent at the public examination. I would like to extend my thanks to all peer reviewers for their time and insights for improving the articles included in this thesis.

The articles in this thesis have been done in co-operation and interaction with many skillful coauthors and scientists. Special thanks should be given to Pekka Alenius, Noora Haavisto, Aleksi Nummelin,Tero Purokoski, Simo Siiriä and Antti Westerlund for their valuable contribution. I also want to thank all the field personnel in FMI, Finnish Environment Institute, $R / V$ Aranda and Finnish Border Guard for making the magic happen in-situ.

I want to thank teachers and lecturers for sharing their time and knowledge. I am particularly grateful to Terhi Renko whose undergraduate courses on computational fluid dynamics were exciting and inevitably steered my scientific interests towards numerical modelling. 
The colleagues, friends and fellow PhD students have made the work more enjoyable during these years. I very much appreciate all of my colleagues in marine research for creating inspiring working atmosphere. Even though I have been working over a decade as a marine scientist in Kumpula, I always felt warmly welcome every time I visited Water and Environmental Engineering unit in Otaniemi. I wish to give special thanks to Ulrike, Lassi, Outi, Tero, Laura, Jaana and Maiju for memorable moments and adventures, whether in work or leisure.

I would like to express my very great appreciation to my family and friends, who have helped me since the beginning. Anna \& the Tupeli family, thank you for the tea and sympathy. I would like to thank my parents as well as my parents-in-law, whose love and care have been with me. Most importantly, I wish to thank my loving and endlessly (peer) supportive spouse, Antti, and my wonderful son, Otso. With you every day has a share of joy, curiosity and love. You are my $A$ ja $O$.

Petra Roiha

Helsinki, November 2019 


\section{Contents}

List of Publications $\quad$ v

Author's Contribution vii

1. Introduction $\quad 1$

1.1 Background . . . . . . . . . . . . . . 1

1.1.1 The Bothnian Sea and Eastern Gotland Basin . 1

1.1.2 Operational oceanography and marine management . . . . . . . . . . . 11

1.1.3 Argo floats . . . . . . . . . . . 15

1.1.4 Hydrodynamic modelling and forecasting . . . 17

1.2 The Research Gap . . . . . . . . . . . . . . . . . . . 19

1.3 Objectives ................... 20

2. Materials and Methods 23

2.1 Argo floats in the Baltic Sea . . . . . . . . . . . 23

2.1.1 Measured variables and units . . . . . . . . 24

2.1.2 The persistency of the currents . . . . . . . 27

2.1.3 The monthly mean values . . . . . . . . . 28

2.2 The forecasting system . . . . . . . . . . . 28

2.2.1 The BALECO model . . . . . . . . . . 28

2.2.2 Generation of the ensemble forecasts . . . . . 29

2.2.3 System verification methods . . . . . . . . . . 31

2.2.4 Illustration of the probabilities . . . . . . . 33

2.3 Validation data . . . . . . . . . . . . . . 34

2.3.1 Observations . . . . . . . . . . . . 34

2.3.2 3D hydrodynamic model data . . . . . . . 36 
$\begin{array}{ll}\text { 3. Results } & \mathbf{3 7}\end{array}$

3.1 Hydrographical measurements . . . . . . . . . 37

3.1.1 A general description of the hydrography

in the Bothnian Sea . . . . . . . . . . . . 37

3.1 .2 Small-scale events . . . . . . . . . . . 39

3.1.3 Estimation of currents . . . . . . . . . 40

3.2 Monthly ensemble forecasts . . . . . . . . . . . . . . 43

3.2.1 Forecasting upwellings . . . . . . . . . . 43

3.2.2 Forecasting harmful algal blooms . . . . . . . 43

3.2.3 Verification of the forecasting system . . . . . . 44

4. Discussion 49

4.1 The developments of the operational system . . . . . . . 49

4.1.1 Observational methods . . . . . . . . . . . . 51

4.1.2 The ensemble forecasting system . . . . . . . 52

4.2 Future work . . . . . . . . . . . . . . 54

$\begin{array}{lll}\text { 5. Conclusions } & 57\end{array}$

$\begin{array}{ll}\text { References } & 59\end{array}$

Licences \& Permissions $\quad 75$

$\begin{array}{ll}\text { Publications } & \mathbf{7 7}\end{array}$ 


\section{List of Publications}

This thesis consists of an overview and of the following publications which are referred to in the text by their Roman numerals.

I Simo Siiriä, Petra Roiha, Laura Tuomi, Tero Purokoski, Noora Haavisto and Pekka Alenius. Applying area-locked, shallow water Argo floats in Baltic Sea monitoring. Journal of Operational Oceanography, 1-15, doi:10.1080/1755876X.2018.15447832018.

II Noora Haavisto, Laura Tuomi, Petra Roiha, Simo-Matti Siiriä, Pekka Alenius and Tero Purokoski. Argo floats as a novel part of the monitoring the hydrography of the Bothnian Sea. Frontiers in Marine Science, 5:324, doi:10.3389/fmars.2018.00324, 2018.

III Petra Roiha, Simo-Matti Siiriä, Noora Haavisto, Pekka Alenius, Antti Westerlund and Tero Purokoski. Estimating currents from Argo trajectories in the Bothnian Sea, Baltic Sea. Frontiers in Marine Science , 5:308, doi:10.3389/fmars.2018.00308, 2018.

IV Petra Roiha, Antti Westerlund and Noora Haavisto. Forecasting upwelling events with monthly ensembles for the eastern coast of the Gulf of Bothnia in the Baltic Sea. Journal of Operational Oceanography, 9, 2, 115-125, 112016.

V Petra Roiha, Antti Westerlund, Aleksi Nummelin and Tapani Stipa. Ensemble forecasting of harmful algal blooms in the Baltic Sea. Journal of Marine Systems, 83, 3, 210-220, 112010. 
List of Publications 


\section{Author's Contribution}

\section{Publication I: "Applying area-locked, shallow water Argo floats in Baltic Sea monitoring"}

PR participated in designing the article, along with SS. SS wrote the first draft of the manuscript. PR analysed the case studies. TP was mainly responsible for operating the floats, and $\mathrm{NH}$ analysed the general float data. PA did most of the literature study with PR. LT instruct this work. Conclusions were reached through a common understanding and the final manuscript was accepted by all the authors.

\section{Publication II: "Argo floats as a novel part of the monitoring the hydrography of the Bothnian Sea"}

NH wrote the first draft with significant help from LT and held the main responsibility for the analysis of the observation data and production of the illustrations. PR, S-MS, LT, and PA contributed to the illustrations. Background research was mainly done by $\mathrm{NH}, \mathrm{PR}$, and PA. TP was responsible for the technical support and acquisition of data. All the authors contributed to the evaluation of the data, wrote sections for this manuscript, and revised and approved the sent version.

\section{Publication III: "Estimating currents from Argo trajectories in the} Bothnian Sea, Baltic Sea"

All the authors contributed to the design of this study. PR wrote the first draft and largely did the analyses for the observations and model results. S-MS and NH contributed to analyses and illustrations. PR, 
$\mathrm{NH}$ and PA did literature and background research. AW did the 3D modelling for this study and contributed to analysing the model results. TP participated significantly in the acquisition of the data and evaluation of the measurements with $\mathrm{PR}$ and $\mathrm{NH}$. All the authors wrote sections for this manuscript, and revised and approved the sent version.

\section{Publication IV: "Forecasting upwelling events with monthly ensembles for the eastern coast of the Gulf of Bothnia in the Baltic Sea"}

PR had the main responsibility for outlining the article, conducting the analysis and reaching the conclusions with the other authors. PR also was responsible for writing the paper and managing the publication process. AW implemented the forecasting system, analysed the model and participated in the writing and in making conclusions. $\mathrm{NH}$ went through the tide gauge data and analysed the upwelling cases.

\section{Publication V: "Ensemble forecasting of harmful algal blooms in the Baltic Sea"}

PR had the main responsibility for outlining the article and conducting the analyses. PR was also responsible for the writing and handling the publication process. AW implemented the forecasting system and validated the model. AN analysed a case study and drew the figures. TS instructed this work. All the authors wrote parts of the manuscript, and the conclusions were made in common understanding with all the authors. 


\section{Introduction}

\subsection{Background}

\subsubsection{The Bothnian Sea and Eastern Gotland Basin}

The dynamics in the Baltic Sea are driven by topographical, meteorological and hydrological factors. The Baltic Sea is permanently stratified due to the facts that there is saline water entering the basin from the North Sea through the Danish straits and large amount of fresh water coming from the rivers. The Baltic Sea and its sub-basins, surrounding countries and drainage area are shown in Figure 1.1.

The layered structure of the water column restricts the wind's effect upon the upper layer, typically above the depth of 40-80 metres. The upper layer and the lower layer are separated by the halocline. During the summer there is typically a well-mixed surface layer formed by heating and wind-induced mixing, that is typically between 15-20 metres deep. In the autumn this thermocline disappears due to thermal convection and turbulent mixing. Further information of the hydrography of the Baltic Sea can be found in the work of Leppäranta and Myrberg (2009)

In this study the focus is on two sub-basins: the Bothnian Sea and the Eastern Gotland Basin (Figure 1.1). The Gulf of Bothnia is the northernmost basin of the Baltic Sea and the Bothnian Sea is the southern part of the gulf. It is separated from the Åland Sea by a shallow sill so that the more saline bottom water from the Baltic Proper cannot enter the basin. 


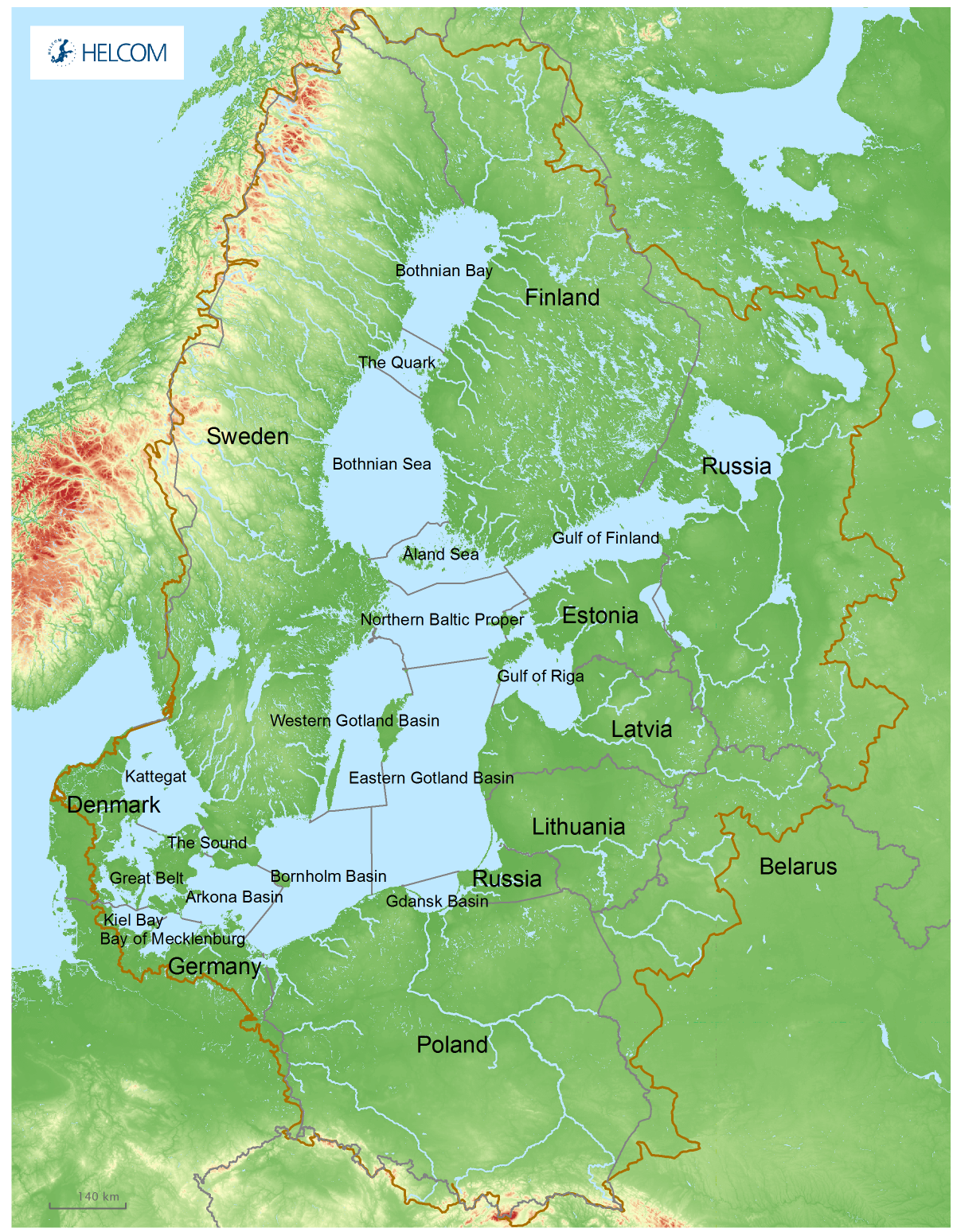

Figure 1.1 A map of the Baltic Sea sub-basins, surrounding countries and drainage area (HELCOM 2018b). 
In the north the Bothnian Sea and the Bothnian Bay are separated by the Quark. The maximum depth in the Bothnian Sea is 293 metres found in Ulvö Deep, near the Swedish Höga Kusten ("High Coast"). The mean depth is 66 metres.

The Eastern Gotland Basin is a part of the Baltic Proper. The southern mouth of the area is the Stolpe Channel. The northern line between the Eastern Gotland Basin and the Northern Gotland Basin is located along the line from Fårö to Gotska Sandö and Ristna. It is large bowl-shaped basin with a mean depth of 77 metres and a maximum depth of 249 metres in the Gotland Deep.

Coastal upwelling is a fairly common phenomenon in both basins (Lehmann et al. 2012). Harmful algal blooms (HAB) are more severe in the Baltic Proper (Rönnberg and Bonsdorff 2004) and the marine traffic is heavy (HELCOM 2018a). The Bothnian Sea, on the other hand, is less saline with shallower mean depth, and parts of it freezes over the course of an average winter (Leppäranta and Myrberg 2009).

In general, the deep-water oxygen conditions in the Bothnian Sea are fair or better and the hydrographical conditions support this state. However, with profound changes in the hydrographic regime or an increase in anthropogenic loads, hypoxic conditions may occur (Raateoja 2013). In the Baltic Sea in general, the ecological food web is affected by environmental factors and human influence (Österblom et al. 2007). The long-term changes in the Bothnian Sea food web were studied closely by Kuosa et al. (2017). They found out that the recent changes in deep-water intrusion from the Baltic Proper affect salinity and the stratification. This in turn has an effect on the structure of the phyto- and zooplankton communities.

In the Baltic Proper algal blooms have been a fairly common phenomenon due to the anoxic conditions in the bottom of the sea, where phosphate is released first into the deep water and from there to the surface water. A high phosphate concentration is a prerequisite for the nitrogen-fixing cyanobacteria that cause the summer blooms, but the local weather conditions also play a crucial role (Bianchi et al. 2000, Raateoja et al. 2011).

In contrast to the Baltic Proper, HABs have been fairly rare in the Gulf of Bothnia, partly because the oxygen situation in the bottom is fair. Apparently, in recent years the nutrient situation has been changing in favour of harmful algae (Jaanus et al. 2011). The hypothesis is that phosphorus 


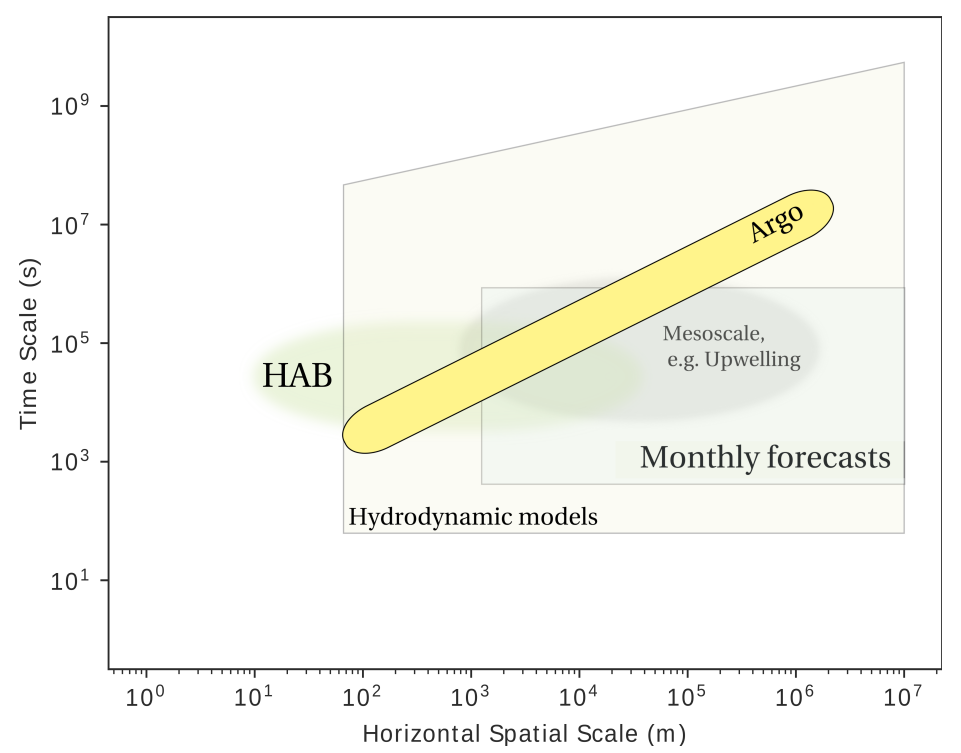

Figure 1.2 Spatial and temporal scales in the sea. Figure after Stommel (1963) and Dickey (2003).

rich water is entering the Bothnian Bay from the Baltic Proper, making nutrients available for algae. (Rolff and Elfwing 2015).

The changes in the climate will affect the Baltic Sea as well. The warming trend can be already seen and it will continue in the future (BACC II and Author Team 2015). The effects of the climate change can be modelled and projected and on-going observations are essential to be able to make well-informed decisions (Andersson et al. 2015).

In the following section the studied phenomena are described more closely.

Spatial and temporal scales in the sea

In this study the focus was on physical and biochemical phenomena, which are closely related and have an effect on the marine environment and regional climate. Measurements focused on temperature, salinity, oxygen concentration and currents. The forecasting methods focused on upwellings and HABs. With the current methods we are not fully able to understand and measure the crucial phenomena that take place on the mesoscale and submesoscale. 
The mesoscale embeds the range of marine features that span from tens to hundreds of kilometres and has time scales ranging from days to weeks (See Figure 1.2). In the Baltic Sea the range of the mesoscale is typically from $5 \mathrm{~km}$ to $20 \mathrm{~km}$ and it depends on wind forcing as well as buoyancy forcing. Many of the currents, fronts and eddies take place on this spatial and temporal scale. In particular, many chemical and biological processes take place on the mesoscale (McGillicuddy 2016) and submesoscale (Lévy et al. 2012). In the climatological scale, homogenous area for the Baltic Sea water masses was defined by Haapala and Alenius (1994) to be $30^{\prime} \times 1^{\circ}$ or $55 \mathrm{~km} \times 55 \mathrm{~km}$ (latitude $\times$ longitude).

The mesoscale can be numerically defined by the internal Rossby radius. The Rossby radius is basically the horizontal scale at which the earth's rotation effects become as important as buoyancy effects (Gill 1982, Ch. 7.7.5 The Rossby Radius of Deformation). It varies with latitude, basin depth and regional and seasonal variations in stratification. The Baltic Sea is located in latitudes where the wind forcing is strong. The changes in the stratification and the wind conditions cause the mesoscale to have a large variance within the Baltic Sea. The smallest Rossby radius values are found in the Belt Sea and the Gulf of Finland in autumn (1.3-2 km) (Fennel et al. 1991, Alenius et al. 2003) and the largest values are found in the Gotland Deep (11.9 km) (Alenius et al. 2003). The Bothnian Sea was not considered in the aforementioned studies. An estimate of the internal Rossby radius scale in the Bothnian Sea was presented by Westerlund and Tuomi (2016); they provided an expert estimation of the radius to be $2-5 \mathrm{~km}$. In this work the focus is in mesoscale and it is defined as presented above. There are other definitions for mesoscale and atmospheric scientists regognise also sub-categories. Sub-mesoscale and large scale are mentioned in the meaning of smaller and larger scales than the mesoscale, respectively.

As seen in Figure 1.2, it is possible to measure and forecast the aforementioned scales to some extent, but further studies are still needed. The spatial resolution with the monthly forecasts in this study is $6 \mathrm{NM}$ and the forecasted area is the Baltic Sea (see Section 2.2.1). The temporal resolution for the monthly forecasts is in an order of days. This resolution covers most of the mesoscale phenomena. More advanced hydrodynamic modelling systems can theoretically reach as high spatial resolution as that of an order of metres and range up to a global scale. In general, global 
models have lower resolution than the local models due to the limited computational and storage capasity of modern computers. In practice, the model run is a compromise between time span, size of modelled area and spatio-temporal resolution.

In this work the Baltic Sea Argo floats were used. The measurements can reach a spatial resolution ranging from hundreds of metres to kilometres and the range of the mission can extend up to hundreds of kilometres. The temporal resolution of Argo floats is at best in the order of hours and the range of the mission can be on a yearly scale (see Section 2.1). Argo floats fill spatial and temporal gaps in observational network (Table 1.1).

The interconnection between physics and biology is tight knit: the currents, temperature and salinity have a crucial effect on life in the sea, providing and changing the availability of energy and nutrients for the living organisms (Stigebrandt 2001). The nutrient and carbon cycles depend heavily on temperature. The oxygen conditions can change drastically in time scales ranging from hours to weeks (Viktorsson et al. 2012) and nutrient concentrations have large spatial and temporal differences between sub-basins and between stations within the sub-basins (Sandén and Danielsson 1995). The optimisation of the monitoring station locations for temperature, salinity and nutrient concentrations was analysed in the Baltic Proper by Toompuu and Wulff (1996).

\section{The temperature and salinity structure}

Leppäranta and Myrberg (2009) defined that hydrography characterises the physical and chemical properties of the water column and circulation using empirical methods. Commonly this includes temperature, salinity, pressure and density, alongside some chemical properties such as oxygen concentration, nutrients and turbidity. The temperature and salinity, among other variables, have a great effect on the life of the sea and understanding the air-sea interaction.

The water column structure in the Bothnian Sea is two layered in vertical direction with a weak halocline at the depth of 50-60 metres. The saline water in the bottom originates from the surface water of the Baltic Proper, entering the Bothnian Sea through the Archipelago Sea and Åland Sea (Marmefelt and Omstedt 1993). The maximum salinity in the bottom is 6-7. In the summertime the thermocline forms at the depth of 15 metres 


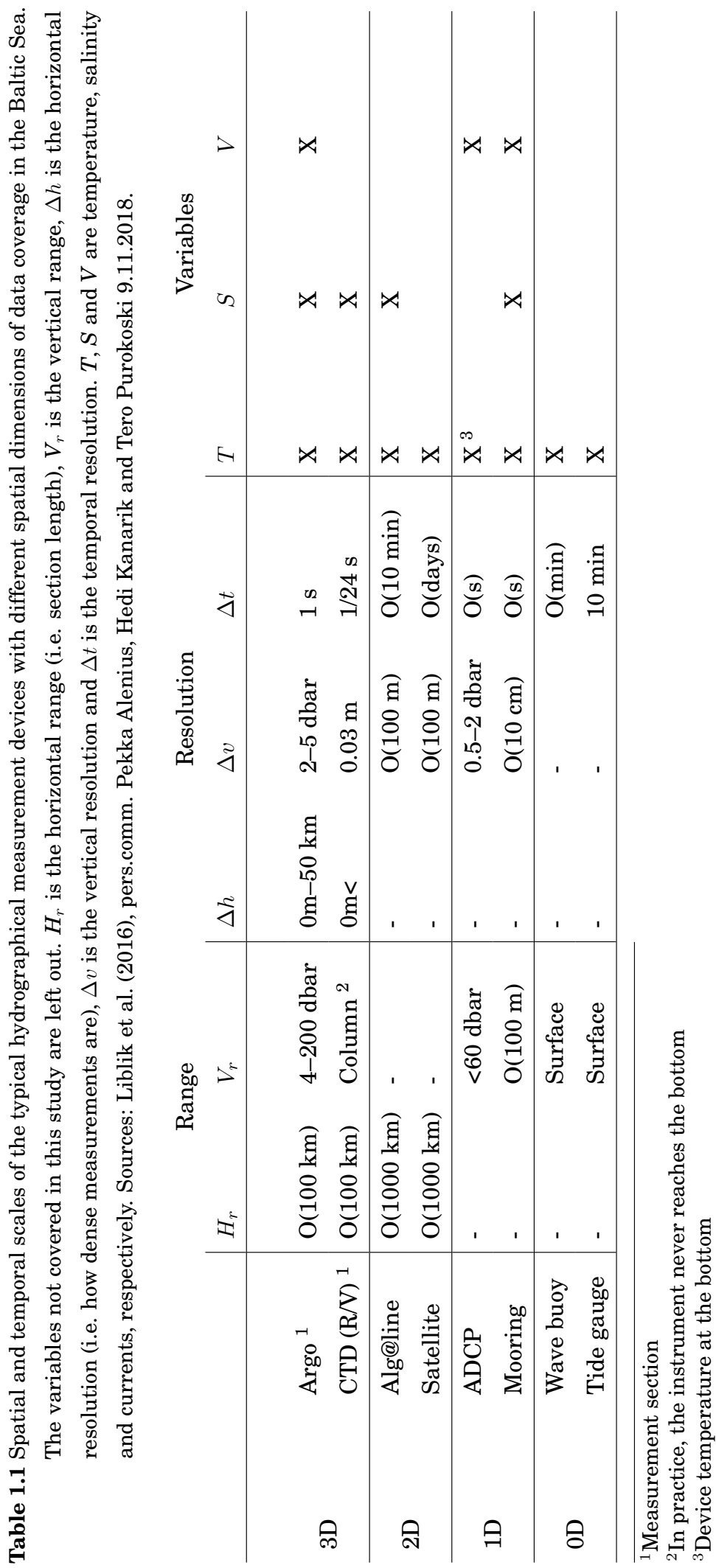


on average. The mean horizontal circulation in the north-south direction takes place in the surface layer in cyclonic motion. The wind forcing has a strong effect on the currents, especially at the surface, which causes the strong variation in the current field (Håkansson et al. 1996).

The water column in the Baltic Proper is strongly stratified and the maximum salinity at the depth of 200 meters can be up to 13 . The bottom water is only ventilated by incoming water pulses from the North Sea. The biggest pulses are called major Baltic Inflows (MBIs), which have been registered since 1887 (Mohrholz 2018); the latest incoming large MBI was detected in 2014 (Mohrholz et al. 2015).

\section{Currents}

Surface currents have been an important factor in the seafaring in the Baltic Sea. The first continuous current measurements in the northern Baltic Sea were made from lightships at the end of the19th century (Mälkki 2001). Witting (1912) was the first to study the surface currents in the Bothnian Sea. Palmén (1930) formulated the first concept of the cyclonic surface current field in the Finnish sea areas based on the lightship observations. Later, Hela (1958) studied the currents in the upper layers and hydrography in the Bothnian Sea. The year 1991 was the Bothnian Sea Year and an extensive measurement campaign on currents was launched, both on surface currents (Uotila et al. 1995) and on currents in water column (Alenius 1993). Only in recent years, after the era of lightships, have the long-term measurements with acoustic Doppler current profilers (ADCPs) and moorings been started. In the deep sea areas, the availability of the data is still heavily dependent on the occurrence of measurement campaigns.

The currents are induced in the Baltic Sea with different mechanisms. The most important are surface wind stress, sea surface tilt (due to the wind or air pressure gradient), thermohaline horizontal density gradient and potential tidal forces. The currents are further affected by friction, local topography and Coriolis force. More information on currents can be found, for example, in Leppäranta and Myrberg (2009).

Currents are an important factor for transporting momentum, energy and matter and affecting turbulence in marine environment. The bottom currents cause friction and affect suspension and resuspension of sediments. Locally, for example, the river run-off can change the sea level and thus 
have an effect on the currents. Also, the weather phenomena, such as strong winds and low pressure cells, can tilt the sea surface and cause seiches. In the Bothnian Sea basin the seiche period is in the order of hours, estimated by using the Merian formula (Lisitzin 1974).

\section{Upwelling}

The upwelling phenomenon is a fairly common event in the Baltic Sea (Myrberg and Andrejev 2003, Lehmann et al. 2012, Lehmann and Myrberg 2008). Strong enough winds frequently cause an upwelling somewhere in the Baltic Sea. The wind event must last at least 60 hours, and the wind direction and water column stratification play important roles: when the stratification is strong (in summer time) the wind impulse needed to cause upwelling is much smaller than when the water column is homogenous (Haapala 1994). The atmospheric conditions leading to an up- or downwelling in the Baltic Sea were studied on a large scale by Lehmann et al. (2001), who analysed the effects of the North Atlantic Oscillation on upand downwelling events.

The Bothnian Sea has favourable conditions for the occurrences of upwelling phenomena (Myrberg and Andrejev 2003). When the northerly wind's direction runs along the coast on the right-hand side of the basin, the sea level rises and on the other side it falls due to Ekman transport. Consequently, coastal jets on the both sides of the basin emerge and the coastal water is then replaced slowly with water from the central basin (Krauss and Brügge 1990).

In the Baltic Proper the surroundings of the Gotland Island have a pronounced up- and downwelling system. The south-westerly winds cause upwellings on the east coast of the island and downwellings on the western coast. The width of the upwelling zone is $10-20 \mathrm{~km}$ and the length is around $150 \mathrm{~km}$ (Myrberg and Andrejev 2003).

The upwelling characteristics in the Baltic Sea have been studied with different methods. Ferryboxes crossing the Gulf of Finland have been used to analyse the upwelling features (see, e.g. Kikas and Lips 2016). Satellite sea surface temperature (SST) analysis of upwelling events was made by Kahru et al. (1995) with the Advanced Very High Resolution Radiometer (AVHRR) instrument and by Uiboupin et al. (2012) using Moderate Resolution Imaging Spectroradiometer (MODIS) data and Chl- $a$ with MEdium Resolution Imaging Spectrometer (MERIS) data. Myrberg 
and Andrejev (2003) modelled and analysed statistically the upwellings with the Oleg Andrejev-Alexander Sokolov (OAAS) model (Andrejev et al. 2004), and Kowalewski and Ostrowski (2005) studied up- and downwelling events on the southern coast of the Baltic Sea with the Princeton Ocean Model (POM).

The importance of the upwelling phenomenon is that it lifts cold and nutrient-rich water to the near surface (euphotic) layer, where it can be used by biological processes. This has an effect on physical and chemical patterns (Lips et al. 2009) and eventually on the ecosystems and therefore, for example, on algal blooms (Vahtera et al. 2005, Zhurbas et al. 2008, Lips and Lips 2008).

In the Baltic Sea, the upwelling phenomenon may play a key role in replenishing the nutrients necessary for the biological activity later in the summer when the amount of nutrients is diminished in the euphotic zone. In the areas where upwelling lifts phosphorus-rich water, the nitrogenphosphorus (N/P) ratio becomes small, favouring potentially harmful, nitrogen-fixing blue-green algae (Lehmann and Myrberg 2008, Vahtera et al. 2010, Wasmund et al. 2012). The upwellings may also have an effect on the reproductivity of fish by changing temperature and salinity conditions (Nissling et al. 2006). The upwellings affect the lower boundary layer of the atmosphere (Sproson and Sahlée 2014). The cold water can cause fog formation in very local coastal areas (Leppäranta and Myrberg 2009). The rapid fog formation is difficult to forecasts without understanding the dynamics of the sea. The upwelling phenomenon has an impact on the $\mathrm{CO}_{2}$ balance between air and sea (Krapivin and Varotsos 2016). The frequent upwellings in the Baltic Sea are expected to have a major impact on the Baltic Sea carbon budget (Norman et al. 2013). Globally, the upwelled, $\mathrm{CO}_{2}$-enriched waters, can have an impact on shallow water ecosystems (Melzner et al. 2013).

\section{Harmful algal blooms}

The history of algal bloom studies in the Baltic Sea begins at the end of the 19th century (Finni et al. 2001). In early studies, the algal bloom observations were from coastal areas, and systematic recordings from the open ocean started after the World War II. Since the 1960s cyanobacterial blooms have been frequent in the Gulf of Finland and Baltic Proper, which indicates abundant nutrient availability. Groetsch et al. (2016) concluded 
that the spring blooms in the Baltic Sea have weakened but lengthened from the year 2000 to 2014 .

Eutrophication is one important factor that increases the number of algal blooms. In the Baltic Sea the trend for eutrophication has been growing in the 112-year period and a large part of the Baltic Sea is classified as "affected by eutrophication" (Andersen et al. 2017). Eutrophication is the main culprit for many environmental issues in the Baltic Sea, including the blooming of harmful algae (Heisler et al. 2008). Basically, the more nutrients that are available, the more algal blooms. In the Baltic Sea, the intensity of spring blooms seems to have reduced from 2000 to 2014 due to the reductions in nutrient loading (HELCOM 2018b). However, in the Bothnian Sea the amount of harmful algal blooms has increased, which is in connection with an increase in phosphate concentrations (Korpinen et al. 2018).

The relation between the phosphorus concentration and cyanobacterial blooms was recognised four decades ago (Niemi 1979). This known relationship has been utilized in practical and operational uses. However, the weather additionally controls how the algae situation develops in the end. The effect of atmospheric forcing on the nutrient availability was studied in the Baltic Sea by, for example, Lehtoranta et al. (2017) who concluded that the nutrient inputs to the Gulf of Finland cannot explain the inter-annual variation of the nutrient pools and that they are related to the atmospheric conditions and stratification of the water column.

The difficulty in forecasting the algal situation and blooms can be demonstrated by a contemporary examplefrom the sea areas surrounding Finland: in the beginning of June 2018, the assessment of the number of algae blooms predicted a lower risk of blooms than earlier years (SYKE 2018a). However, the exceptionally warm weather increased the algal growth so that the algal blooms were the strongest of the 2010's and at the largest the blooms covered almost the whole of the Gulf of Finland, as well as the southern parts of the Archipelago Sea and Åland Sea (SYKE 2018b).

\subsubsection{Operational oceanography and marine management}

The first interesting marine phenomena for the seafaring were waves, tides and currents as they were crucial elements for people living by the shore and getting their livelihood from the sea. 


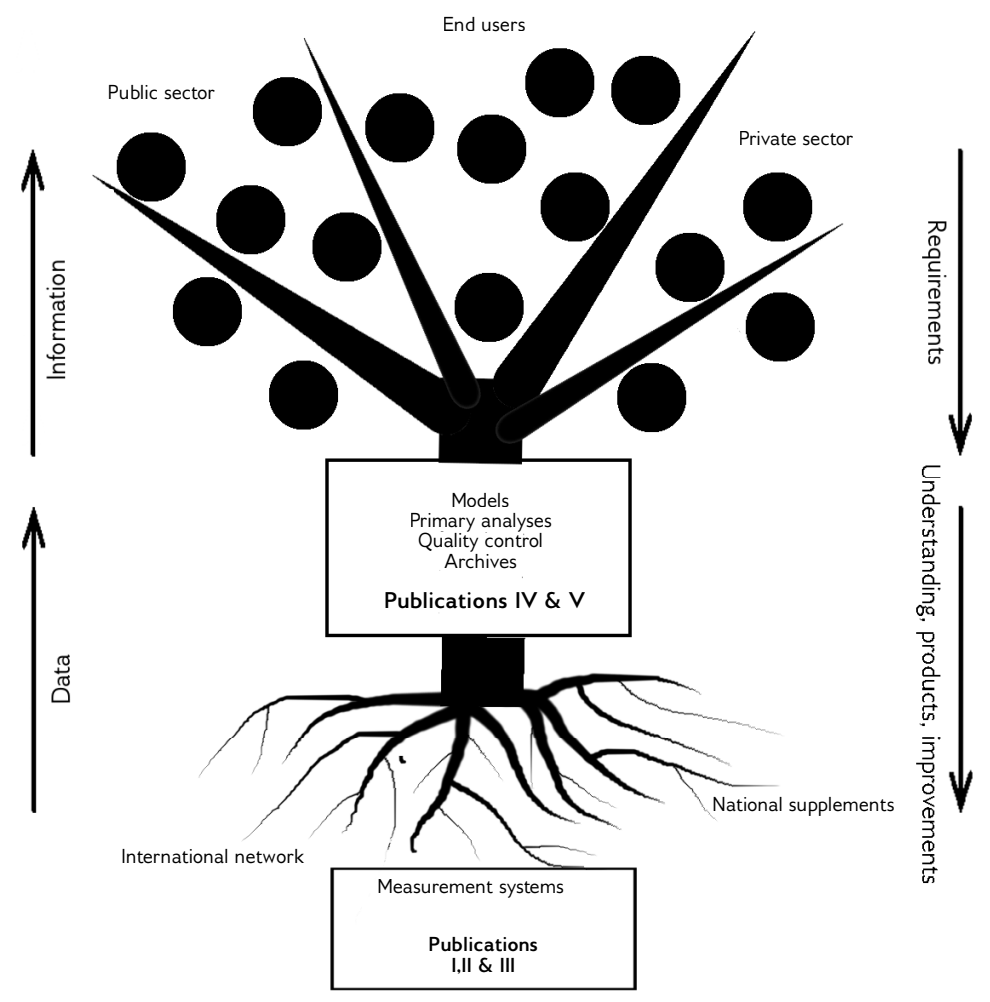

Figure 1.3 An outline of the operational oceanographic system (simplified and modified from Bell et al. (2013)). The publications included in this thesis and the main areas of studies are marked on the picture. 
During the Age of Discovery (1400-1700) the ocean explorations were mainly cartographic and surface observations. The first scientific voyages were made in the late $1700 \mathrm{~s}$. At the same time, the first hydrographic measurements in the Baltic Sea were carried out (Fonselius and Valderrama 2003). World War II had a major effect on the development of the first wave forecasts and thus it gave the first push to the development of the operational oceanography (Schiller and Brassington 2011).

Operational oceanography is a multi-disciplinary branch of science that aims to benefit many aspects of society (Figure 1.3). However, there is no single definition of operational oceanography. One description is given by Flemming (2002) as follows:

Operational oceanography is the provision of scientifically based information and forecasts about the state of the sea (including its chemical and biological components) on a routine basis, and with sufficient speed, such that users can act on the information and make decisions before the relevant conditions have changed significantly, or become unpredictable. (Flemming 2002).

To be operational, the service needs to be real time, and routinely and robustly delivered. The services can include ocean observations, along with nowcasts and forecasts of different lengths. Usually the main difference from the scientific state of the art is the demand of robustness, limitation of computational capacity and real-timeliness. Robustness of the operational models commonly means that model versions are older than the state-ofthe-art, but more tested and reliable in operational environment.

The need to understand and forecast the conditions in the ocean has a long history, but one important breaking point in modern times was the Rio Conference Earth Summit in 1992 and the publication of Agenda 21 (Sitarz 1993), which emphasises the meaning of the oceans and predicting the ocean state (Pinardi and Woods 2002).

The operational marine systems helped to mitigate the effects of several disasters globally in the 2010s: Deepwater horizon oil spill in the Gulf of Mexico in 2010 (Liu et al. 2011), the Fukushima Dai-ichi nuclear power plant accident in Japan in 2011 (Tsumune et al. 2012) and the grounding of Costa Concordia on the shore of Italy in 2012 (Dominicis et al. 2014), to name but a few. 
The state of the Baltic Sea is monitored and managed both internationally and nationally. International politics have also greatly shaped the environmental protection of the Baltic Sea and the establishment of the Helsinki Commission (HELCOM) (Räsänen and Laakkonen 2007). During the 40 years of HELCOM, the loads from many pollution sources have decreased but many problems still exist (Elmgren et al. 2015).

At the international level, the EU Marine Strategy Framework Directive (MSFD; Directive 2008/56/EC; European Parliament and Council (2008)) has had a guiding effect on the national marine strategy. The ecological indicators are constantly developed to describe the environmental status and the goal is to eventually reach a Good Environmental Status (GES) in 2020 (see, e.g. Fleming-Lehtinen et al. 2015). The Finnish Marine Strategy Plan is composed of three parts, namely: "The State of the Baltic Sea" (Korpinen et al. 2018), "The Baltic Sea Monitoring Programme" (Korpinen et al. 2015) and "The Marine Management Action Plan" (Laamanen 2016). The national report of the state of the Baltic Sea is closely related to the international HELCOM report (HELCOM 2018b).

The other legislation affecting operational oceanography in Finland is the law "Laki Ilmatieteen laitoksesta" (212/2018), which defines that the Finnish Meteorological Institute (FMI) should advance physical oceanography. More precisely, it is obliged to warn citizens of hazardous situations in the sea; FMI is responsible for maintaining and delivering marine forecasts and develops new observational and modelling methods for marine services and for scientific purposes. The aims of these services could be, for example, predicting events that may threaten life, safety or security, or events that affect the marine health (Schiller and Brassington 2011). These services could also be used as a tool in marine spatial planning (MSP; Ehler and Douvere 2009).

The Finnish Marine Research Infrastructure (FINMARI) combines the national marine research infrastructure together. This covers, for example, research vessels and institutes, and also the Argo floats and other offshore observational platforms. Finland is also a founding member of the Euro-Argo European Research Infrastructure Consortium (ERIC), which is responsible for the overall coordination of Euro-Argo (Finnish Research Infrastructure Committee 2013). 
In Finland oceanographic research began with sea-level studies, ice studies and studies of water masses and hydrography (Mälkki 2001). Today, there are operational water-level measurements from 14 tide gauges along the Finnish coast, and there are wave data available from wave buoys during the ice-free season from the Gulf of Finland, the Baltic Proper and the Gulf of Bothnia. The Alg@line project measures the surface data from commercial ships in the Gulf of Finland and the Gulf of Bothnia. Several Argo floats send hydrographical data from the Baltic Proper, the Bothnian Sea and the Bothnian Bay.

In Finnish sea areas, the currently used operational models are hydrodynamic 3D model, the wave forecast model, the ice model and the water-level forecasts. Also, the Copernicus marine environment monitoring service (CMEMS) is making operational products for the Baltic Sea. There are other operational systems studies on the Northern Baltic Sea's water level and currents. For example, Lagemaa (2012) and Lips et al. (2016) studied sub-mesoscale fetures with models and multiple sensors, and Nowicki et al. (2019) studied upwellings in the southern Batic Sea.

Tonani et al. (2015) and She et al. (2016) analysed the future needs of the operational systems. Important developments that are needed are a higher model grid resolution, the development of a biogeochemical model coupled with a physical system, a coupled ocean-ice-wave-atmosphere forecasting system and improved data-assimilation systems. They also pointed out that ensemble approach in the operational forecasts should be studied further.

\subsubsection{Argo floats}

Argo floats are free-floating, autonomous ocean measurement devices, which can carry a variety of sensors and operate in distant sea areas for extended periods of time. There is a satellite connection to the float; some floats have a two-way Iridium satellite connection and they can send measured data in real time to the data centre. Argo missions can also be altered via satellite and floats can be recovered at the end of their mission if they are somewhat near the coast. 
Thompson et al. (2017) concluded that in the future, the ocean observing systems need to be heavily autonomous in order to be able to achieve temporally and spatially dense measurement coverage of a high quality. The mission planning should be developed so that it can autonomously determine the sampling directives based on the observations from the water column, models and remote sensing. The interplay between physical circulation and biogeochemical cycles is of great interest. With the currently existing methods they are captured occasionally.

\section{The Argo project}

The Argo project (Roemmich et al. 2001) was the first project to collect a vast global data set from the upper layer of the ocean $(<2000 \mathrm{~m})$. Initially, the Argo floats collected salinity and temperature data to assess the signals of the climate change. Since then the Argo technology has matured and the variety of the sensors has also increased (Riser et al. 2016). Currently there are three models of Argos in use: PROVOR built by KANNAD (France), Autonomous Profiling Explorer (APEX) built by Teledyne-Webb Research Corporation (USA) and the SOLO float built by the Scripps Institution of Oceanography (USA) (Thomson and Emery 2014). In this study only the APEX floats were used.

Nowadays all Argo floats are equipped with salinity, temperature and pressure sensors (Gould et al. 2004) but the amount of additional sensors for Argo floats has grown (Johnson et al. 2009), including sensors for oxygen (Körtzinger et al. 2004), for $\mathrm{pH}$ (for analysing $\mathrm{pCO}_{2}$ ) (Williams et al. 2017), for fluorescence and turbidity (Boss et al. 2008) and for chlorophyll-a (Xing et al. 2011) to name but a few.

In the northern latitudes, and thus, also in the Baltic Sea, ice is an important environmental factor affecting Argo missions. The risk of colliding while surfacing or being stuck in the middle of ice is real. However, methods for measuring under ice have been developed and data has become available from ice-covered areas (Klatt et al. 2007, Wong and Riser 2011).

Nowadays the Argo data is used in climate studies and it has revealed the ongoing heating in the deep oceans (Roemmich et al. 2015, von Schuckmann et al. 2016) and marginal seas (Schroeder et al. 2017) along with potential changes in chemistry and biology (Howes et al. 2015). Argo floats have brought more information, especially about the world ocean's heat 
storage, and thus helped to understand the energy balance and the climate change, as well as variability of the temperature and salinity in the world's oceans (Ninove et al. 2016).

The Argo project has also had a great impact on ocean forecasting and it has become a crucial part of developing links from seasonal to decadal predictions (Le Traon 2013).

\subsubsection{Hydrodynamic modelling and forecasting}

The 3D models used in operational oceanography solve the Navier-Stokes equations for a thin layer on a rotating planet. The equations may be simplified in several ways and certain assumptions may be introduced (incompressibility, hydrostatics). Models that solve these equations are called ocean general circulation models (OGCMs) (Schiller and Brassington 2011). The Baltic Sea has been extensively modelled by different models in the 2000s. To name some examples, Myrberg and Andrejev (2003) studied main upwelling regions in the Baltic Sea with the OAAS model, Meier (2001) studied mixing in the Baltic Sea and Meier et al. (2006) deep water ventilation with the Rossby Centre Ocean model (RCO). Tuomi et al. (2012) studied mixing in the Baltic Sea with COHERENS model (Luyten et al. 1999). Burchard et al. (2009) studied bottom currents in the western Baltic Sea and Holtermann et al. (2014) studied deep water dynamics and mixing in a stratified basin in the Baltic Sea with the General Estuarine Transport Model (GETM) (Burchard et al. 2004). The Nucleus for European Modelling of the Ocean (NEMO) model (Madec and the NEMO team 2008) has been used in the Baltic Sea (Hordoir et al. 2013, 2018). Westerlund and Tuomi (2016) used NEMO to analyse mixing in the northern Baltic Sea.

In the Baltic Sea there are some specific challenges in modelling. In general, the weather forcing has large impact on the results from ocean models (Treguier et al. 2017). In the Baltic Sea, the issue was discussed by, for example, Tuomi (2014) and Westerlund (2018). The weather forcing has to be selected carefully and with sufficient resolution, but oftentimes a forcing with sufficient resolution is not available. The river input is also a dominant feature in the hydrography and its modelling appears to be difficult (Placke et al. 2018). Also, to be able to describe mesoscale phenomena correctly, there is need for a sufficiently high horizontal resolution. 


\section{Ensemble forecasts}

Forecasting is always coping with uncertainties. The errors are everywhere, ranging from being in observations to being in model setup and code, parameters and interpretation of the data. Moreover, the effect of small errors tends to grow in time when the forecast length increases (Lorenz 1965). To be able to estimate the range of possibilities the estimation of the errors in the system is needed (Leutbecher and Palmer 2008). Treguier et al. (2017) concluded that "the next frontier" regarding the mesoscale forecasts is the systematic use of ensemble approaches, as already used in the weather forecasting and climate scenarios because of the chaotic nature of the mesoscale phenomena.

The ensemble forecasting methods are developed from the Monte Carlo techniques (Metropolis and Ulam 1949). One possibility is to produce several forecasts instead of one deterministic forecast so that it is possible to see the range in which the true result lies. This requires more computational power and different analysis methods.

Ensemble forecasts can be formed with different methods: by running a model with different forcings (e.g. Molteni et al. 1996), by combining multiple ensembles for multi-model multi-analysis ensembles (e.g. Mylne et al. 2002) or by combining the ensemble from different deterministic forecasts (e.g. Ebert 2001). Operational multi-model ensembles for nowcasting exist for the Baltic Sea (Golbeck et al. 2015). The multi-model ensembles for management needs in the Baltic Sea in particular have been under development during this decade (see, e.g. Meier et al. 2014).

The interpretation of the ensemble forecasts is not as straightforward as with deterministic forecasts and specialised methods for interpreting uncertainties have been developed.

The uses for ensemble forecasts are numerous, ranging from marine resources management (Hobday et al. 2016) and operational forecasting (Golbeck et al. 2015) to planning autonomous glider paths during mission (Wang et al. 2013) and weather-scale ice forecasting (Mohammadi-Aragh et al. 2018).

For decision-making, forecasts of different length are of great importance. For example, Hobday et al. (2016) analysed the different lengths of forecasts that are important for decision-making concerning fisheries. Middlerange forecasts (7-10 days) are needed for reactive management, such as 
farm maintenance and feeding cycles. Seasonal-scale forecasting (weeks to months) provides an early window for implementing strategies to minimize impacts, for example, for labor needs and harvest time. Monthly forecasts are also used for navigation and route planning in ice (Choi et al. 2015). Climate projections (covering decades to centuries) are used as part of long-term planning tools, for example, for MSP and marine infrastructure.

Climatological multi-model ensembles can be used in the Baltic Sea for estimating the water level (Johansson et al. 2014) and flood risks (Särkkä et al. 2017, Pellikka et al. 2018) over the scale of decennials. Climatological ensembles have been used also in the estimation of sea ice cover (Karpechko et al. 2015)

\subsection{The Research Gap}

Operational oceanography is a fast-developing multi-discipline branch of science that aims to offer tools for better marine management.

The need to understand marine system ecology is rooted in the Rio Climate Conference 1992 (see Section 1.1.2). Other tasks for operational oceanography are to fulfill the management needs to ensure economical, security and safety issues in the marine environment. Siedlecki et al. (2016) recognised the need for developing scientific methods to improve regional predictability in time scales ranging up to the seasonal scale.

To understand the state of the sea the observations are needed. Until the present, the amount of ocean observation has been very small and it has not been possible to study and observe the state of the sea as often and widely as necessary for mesoscale studies.

In general, it is possible to take measurements near the shore fairly often, but for example, in the Bothnian Sea, the hydrographical monitoring is conducted on average four times a year on COMBINE cruises (see Section 2.3.1). With this measurement frequency it is possible that the extremes in the hydrography remain unseen. Knowing the extreme values and changes in physical conditions is important. With understanding of the physics it is possible to analyse, for example, the effects on changes in ecology or gas exchange between the sea and air. The methods for capturing those values should be studied further. 
The need for understanding processes in the ocean and reacting against unwanted changes in advance is important in marine management. The marine management decisions need different information and forecast scales depending of the nature of the task at hand. For example, Operational ensemble HAB forecasts on monthly scale have not been available before for the northern Baltic Sea. In this study, the monthly scale ensemble forecasts are developed to better understand the upwelling phenomena and analyse the feasibility of forecasts of different lengths. The HAB forecasts on a monthly scale are developed to add information on the timing and location of potential algae blooming.

\subsection{Objectives}

Operational oceanography has the broad aim of bringing the best interdisciplinary knowledge achievable to people who need tools for well-informed decision-making.

In this thesis, two important areas of operational oceanography are studied and their methods are improved: measurement systems and forecasts produced with $3 \mathrm{D}$ models. New observational methods are developed further, as are the methods for analysing the data (Figure 1.3). The monthly ensemble forecasting methods are also developed and the results and performance are analysed.

The appended publications are organised so that the first three publications are more in the field of descriptive oceanography and the development of observational methods and data analysis. The latter two are from the field of computational oceanography and forecasting.

The solid basis of marine science is formed of the observations, so this work begins with measurements and their analyses (Publications I-III). The forecasting methods are analysed in Publications IV and V.

The publications with Argo observations bring us new knowledge about the present state of the sea on a spatio-temporal scale that have been missing so far in certain areas. In Publication I, the usability and piloting of the floats in the shallow seas is discussed. In Publication II the comparison with traditional methods is shown and methods for extracting more data from measurements are studied. In Publication III the methods for extracting and analysing the data from GPS information are developed 
further.

Ensemble predictions brings us more understanding of the future state of the sea; the future needs for these kind of forecasts were described by Hobday et al. (2016) and Tonani et al. (2015). In Publication IV the ability to forecast upwelling phenomena over an extended period of time is discussed.

With Publication V, the subject of how to make the forecasts and their uncertainties understandable for a layperson or decision maker is touched upon. The approach discussed in this publication was also covered in the work of Flynn and McGillicuddy (2018).

This thesis addresses the key questions concerning the research problem of improving the operational system for describing and predicting ecologically and environmentally substantial phenomena:

- How can observational data can be collected and analysed with new methods in order to improve temporal and spatial coverage? (Publications I-III)

- What kind of phenomena can be forecasted well in advance, even within a time scale of weeks? (Publications IV and V)

More specifically, we can divide these questions into smaller subareas with the following objectives:

1. utilise the new autonomous measuring devices and analysis methods in the Baltic Sea - on temporal and spatial scales - filling the gap in the existing observational network.

2. develop new methods to extract additional current information from Argo measurements

3. explore the limits of the predictability of the upwelling phenomenon in the Bothnian Sea

4. evaluate the feasibility of ocean ensemble forecasts predicting HABs and upwellings in the Baltic Sea 
Introduction 


\section{Materials and Methods}

\subsection{Argo floats in the Baltic Sea}

In Publications I, II and III, the piloting of the floats, hydrography and currents was analysed for the first time from the Argo float data from the Bothnian Sea and the Eastern Gotland Basin. In oceans the floats measure profiles from 1000-2000 metres depth and their diving cycle is 10 days. For the Baltic Sea the diving depth is around 100-200 metres and the diving cycle is 1-7 days. A schematic description of the floats' measuring cycle is presented in Figure 2.1.

The special characteristics of the Baltic Sea make the float measurements different to their operation in the oceans. The sea is shallow and the diving settings and the balancing of the float must be adjusted to selected sub-basins because of the brackish water and differences in the salinity. This affects water density and therefore floats' buoyancy. Many areas of the sea are heavily trafficked and therefore the risk of collision while surfacing exists. The northern parts are ice covered during the cold season so ice avoidance is essential for the measurement campaigns lasting over winter.

The Argo floats in the Baltic Sea have temperature, salinity and pressure sensors. Some of them also measure fluorescence and oxygen concentrations. The routes of the missions are shown in Figure 2.2 and the technical details of the floats are described in Table 2.1.

Argo data is first processed and real-time quality controlled by national Data Assembly Centers (DACs) before being sent to the Global Data Assembly Center (GDAC). In general, Argo data is quality controlled in two 


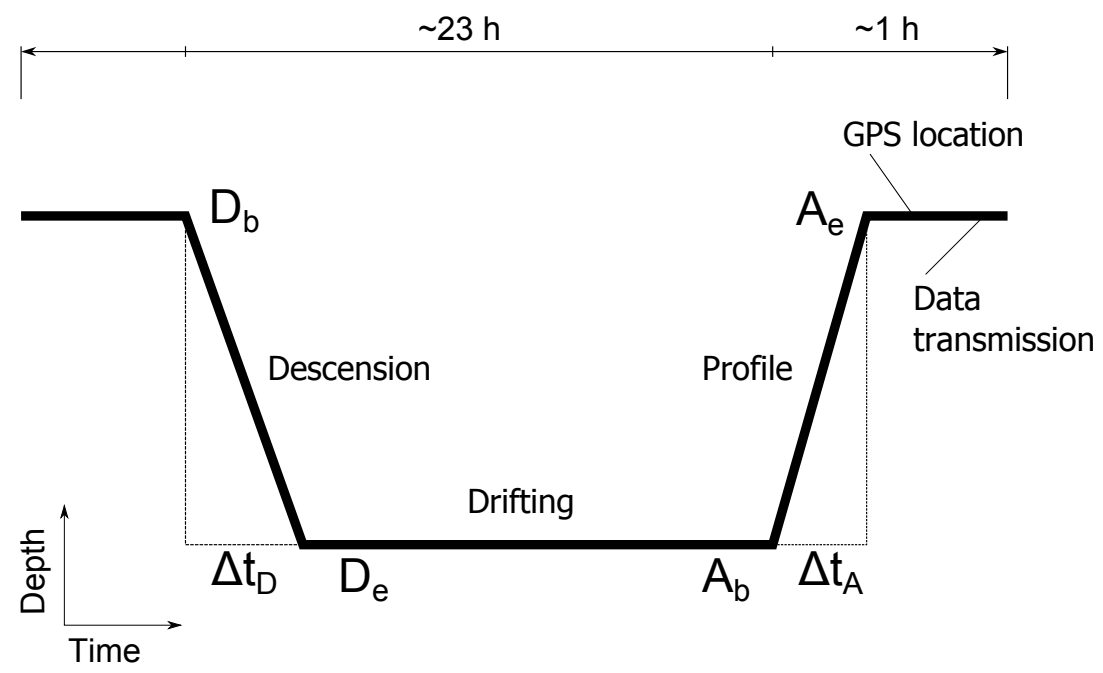

Figure 2.1 Schematic illustration of APEX cycle in the Baltic Sea (from Publication III) The profile starts from the parking depth. $D_{b}$ marks the beginning of the descent to the parking depth and $D_{e}$ marks the beginning of the drifting phase. $A_{b}$ and $A_{e}$ mark the beginning and the end of profile sampling respectively, and $\Delta t_{D}$ and $\Delta t_{A}$ are the descension and ascension times, respectively.

stages: in real time (within 24 hours from recording) and in delayed mode (within 1-2 years) (Barker et al. 2011). For the Baltic Sea measurements, only the real-time quality control is performed. However, the delayed mode quality control is under development.

\subsubsection{Measured variables and units}

For the temperature (T) and salinity (S) measurements in Publications I and II, density and absolute salinity for the Argo and CTD (Conductivity, Temperature, Depth) profiles were calculated using the Python implementation of the Thermodynamic Equation Of Seawater - 2010 (TEOS-10) (IOC et al. 2010). Although the salinity data presented in Publications I and II are in absolute salinity, the values from literature are presented as they were in the original work, which was usually in practical salinity. The difference between absolute salinity and practical salinity is approximately 0.1 in the Baltic Sea, with absolute salinity being higher, and this is taken into account in the comparisons. Temperature shown is the in-situ temperature, except for T-S diagrams, for which potential temperature was 


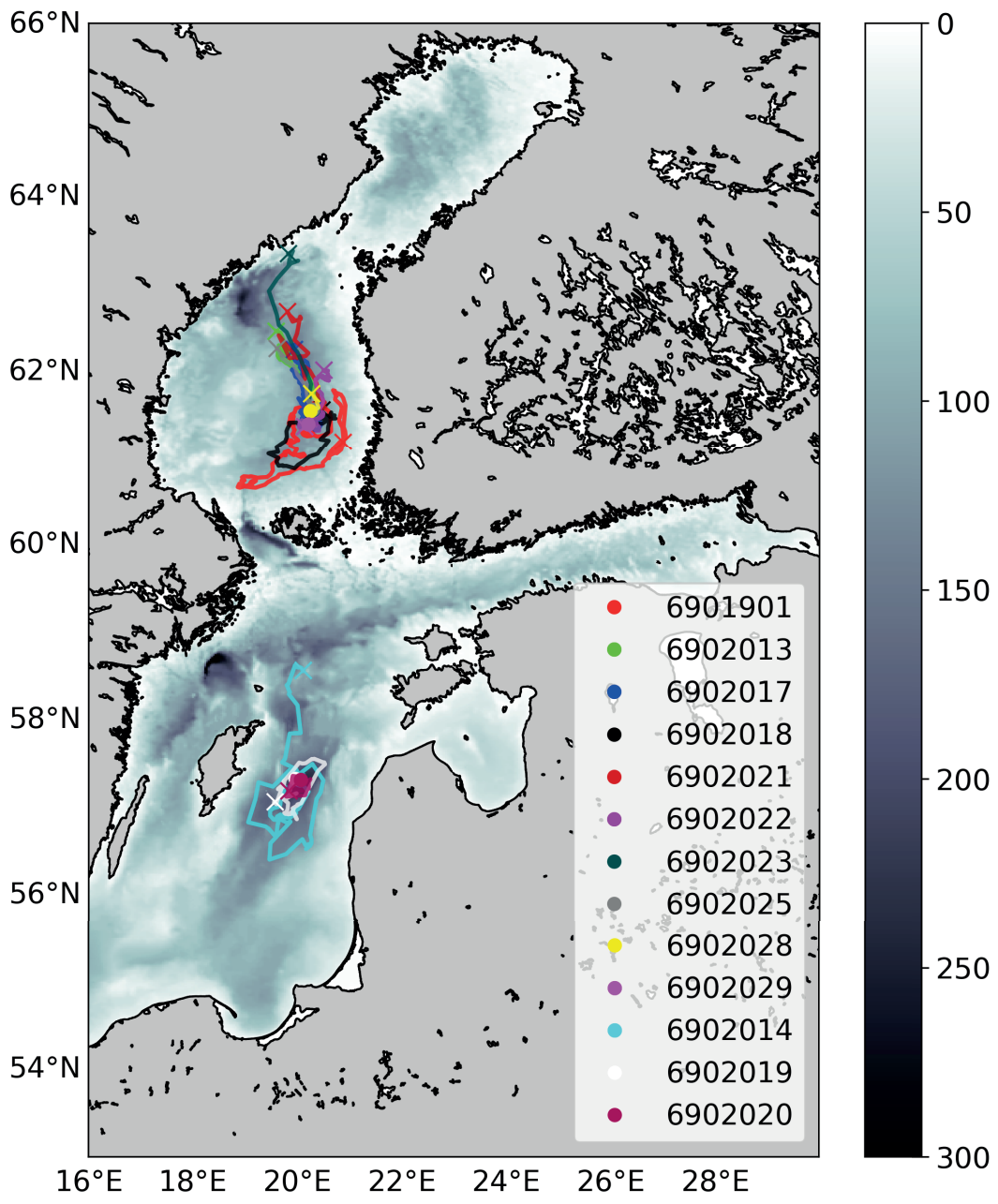

Figure 2.2 APEX measurements in the Baltic Sea (Publications I, II and III). The location of the deployment is marked with a circle and the mission end point with a cross. The details of the missions are presented in Table 2.1. Figure: Simo Siiriä. 


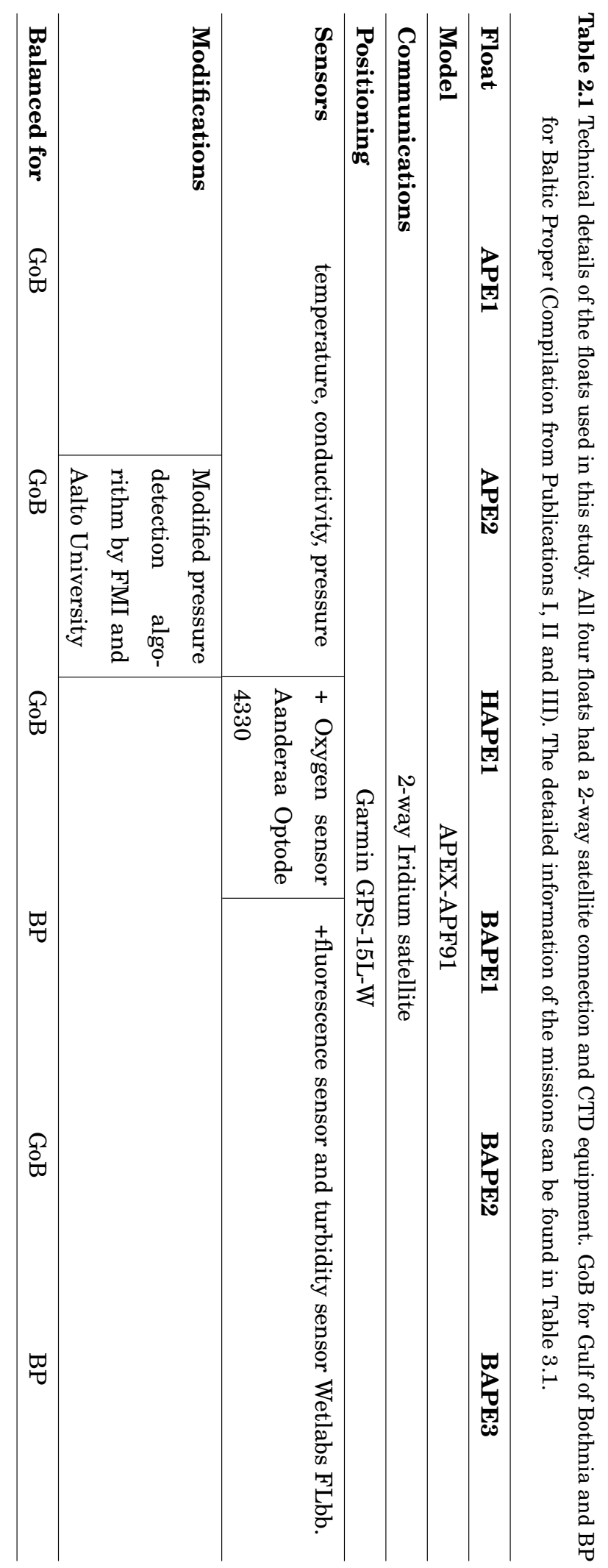


applied. The Argo floats measure the pressure and not directly the depth. In this study the relation between the pressure and depth is considered to be $1 \mathrm{dbar} \sim 1 \mathrm{~m}$.

The location, and thus the movement, of the float is determined by GPS. The GPS error in location is less than 15 metres (95\%). The location is defined once in every measuring cycle, after surfacing. The travelled speed is then calculated from the changed location and the length of the cycle (Publication III).

The currents below 90 dbars are considered to represent the deep currents as this is below the halocline and, according to the results in Publication II, the seasonal variation can reach the depth of almost 100 dbars.

\section{Description of the measurements}

In general, the Argo floats sampled the water column from diving depth to near the surface every 2 dbars until the CTD shut down 4 dbars before the surface due to technical reasons. The exceptions are the profiles that were less than 50 dbars deep, for which, due to a software bug, the sampling interval was 5 dbars. The deepest measured pressure used in this study was 130 dbars.

The average distance from the bottom was estimated from the topography: for the first two missions, A and B (Table 3.1), it was 30 metres and for the rest it was 10 metres. All floats in the Bothnian Sea were deployed within an area of $615 \mathrm{~km}^{2}$, with a distance of $28 \mathrm{~km}$ between each other at most.

The median time between the cycles in the time period of 2012-2016 was 24 hours within the range of two hours to seven days. The longest measurement cycles occurred when the ice avoidance was tested. The shortest possible measurement cycle in the depth range of 100-150 metres is probably from two to three hours.

\subsubsection{The persistency of the currents}

The persistency is a value which indicates the permanence of the currents. In Publication III the deep currents are studied and their persistency is estimated. 
The studied area in the Bothnian Deep (Figure 3.1) was divided to a $3^{\prime} \times 6^{\prime}$ (latitude $\times$ longitude) grid and current observations were averaged for each grid box.

The persistency $(R)$ of the current was calculated by dividing the mean vector speed by the average scalar speed as presented by Palmén (1930):

$$
R=\frac{\sqrt{\bar{u}^{2}+\bar{v}^{2}}}{\frac{1}{N} \sum \sqrt{u_{n}^{2}+v_{n}^{2}}},
$$

where $\bar{u}$ and $\bar{v}$ are the average eastward and northward components of velocity, respectively, $u_{n}$ and $v_{n}$ are the respective components of the velocity in a single cycle, and $N$ is the number of cycles.

\subsubsection{The monthly mean values of temperature and salinity}

In Publication II the monthly mean values of the temperature and salinity were analysed. The amount of Argo and CTD profiles greatly vary between seasons and the same month of different years. The monthly mean values were calculated by first averaging over each month with data and then taking the mean over the years for each month. The amount of measurements is very low below the pressure of 100 dbars, therefore monthly means were considered valid up to a 100 dbars. Winter means were calculated for 2014-2017 due to the lack of winter profiles before 2014 while other seasons also included the years 2012 and 2013.

Halocline and thermocline depths were calculated as the depth of maximum gradient of salinity and temperature. The seasonal halocline was excluded from the analysis by only using measurements under the thermocline when it existed.

\subsection{The forecasting system}

\subsubsection{The BALECO model}

In this study, the FMI's operational three-dimensional, coupled hydrodynamic and biogeochemical model, BALECO, was used (operational until 2011). In Publication IV the focus is on SST and in Publication V on HABs. The model consists of two components: the general circulation model, MIT- 
gcm (Marshall et al. 1997a,b) and an ecological module (Publication V, Appendix A). The computational model was discretised on a spherical polar grid. The grid size was $0.2^{\circ} \times 0.1^{\circ}$ (latitude $\times$ longitude), which is approximately $6 \times 6$ nautical miles $(11.1 \times 11.1 \mathrm{~km})$. The model domain was 120 $\times 108 \times 21$ grid cells (latitude $\times$ longitude $\times$ vertical). The model domain's most south-western corner was located at $53.85^{\circ} \mathrm{N}, 8.7^{\circ} \mathrm{E}$. The biological activity is greatest in the euphotic zone so the vertical resolution of the top most layer was $3 \mathrm{~m}$, reduced to $2 \mathrm{~m}$ in the cells near the coast (Kiiltomäki 2008). The bottom topography was taken from the work of Seifert and Kayser (1995). The spatial discretisation was made with minimum filter at $6 \mathrm{NM}$ intervals. The biogeochemical model appeared to have a tendency to have a slight warm bias of around $0.5^{\circ} \mathrm{C}$ (Kiiltomäki 2008).

The ecological model used in Publication V is based on ecosystem dynamics formalised by Aksnes et al. (1995) and Tyrrell (1999). The model has three phytoplankton groups: diatoms, flagellates and cyanobacteria. These groups have constant mortality rates and they use phosphate, silicate and dissolved inorganic nitrogen (DIN). Diatoms are potentially limited by the availability of silicate. Cyanobacteria can fix molecular nitrogen and therefore they are not limited by the availability of DIN. The flagellates group represents autotrophic flagellates. Altogether, the ecosystem model describes the essence of new production in the presence of three functional groups. Their growth rates depend on nutrient concentrations, irradiation and temperature (Stipa et al. 2003).

The ensemble forecast initial state was taken from the FMI's deterministic Baltic Sea forecast for the forecast's start date of the run. The initial conditions for the deterministic forecast, both physical and chemical conditions, were obtained from the winter monitoring data of the HELCOM COMBINE programme for the winter 2007-2008. The observations were interpolated in three dimensions with a robust nearest-neighbour interpolation and then supplemented by climatological values for the North Sea from the World Ocean Atlas (Boyer et al. 2006).

\subsubsection{Generation of the ensemble forecasts}

In Publications IV and V the ensemble forecasts were created from an unperturbed initial ocean state by running the model several times with perturbed sets of weather forcings. The unperturbed ocean state was taken from the routinely produced deterministic short-term Baltic Sea model 
forecast. The weather ensembles were from the monthly forecasting system of ECMWF (European Centre for Medium-Range Weather Forecasts), which is based on the Integrated Forecasting System atmospheric model (from cycle CY32R3V in 2008 to CY35R3 in 2009). They were created with the singular vector method (Molteni et al. 1996). The weather parameters used as external forcing for the BALECO model were six-hourly winds at $10 \mathrm{~m}$, temperature and dew point temperature at $2 \mathrm{~m}$ and 12-hourly surface solar radiation and surface thermal radiation. The wind stress was calculated by the model of ECMWF for $10 \mathrm{~m}$ wind forcings.

In some cases with stormy winds, the wind stress grew large in certain areas of the model domain, destabilising the system. As model stability and forecast availability are paramount for an operational forecasting system, this is compensated for by restricting the stress value growth over a threshold value. These weather ensembles consist of 50 perturbed ensemble members and an additional deterministic unperturbed control run. Forecasts were made at one-week intervals.

\section{Upwelling forecasts}

Haapala (1994) used the wind impulse per unit area to quantify the effect of wind. He found that the wind impulse needed to cause an upwelling during thermal stratification was $4000-5000 \mathrm{~kg} \mathrm{~m}^{-1} \mathrm{~s}^{-1}$ and in a thermally homogenous situation it was $10500-14000 \mathrm{~kg} \mathrm{~m}^{-1} \mathrm{~s}^{-1}$. Impulses calculated from the input fields used in this work are in agreement with these findings. The upwelling forecast was showcased in the Publication IV, where an upwelling phenomena was detected from satellite images and from in-situ measurements, when possible.

During an upwelling event, the typical change in surface temperature is from 1 to $5^{\circ} \mathrm{C} /$ day (Lehmann and Myrberg 2008). Accordingly, $1^{\circ} \mathrm{C} /$ day was used as a threshold lower limit for an upwelling event. In forecasting the upwelling events, the interest is mainly on the timing in order to be able to, for example, estimate the possibility of fogginess in a coastal area. The monthly scale prediction could then be refined by shorter-term forecasts. In Publication IV the forecast was evaluated as being successful if the cooling period started during the upwelling period in the tide gauge and satellite observations. 
The model calculates the amount of cyanobacteria as a molar amount of nitrogen (N). Therefore, to be able to calculate the chlorophyll-a concentration in $\mathrm{mg} \mathrm{m}^{-3}$, the results were compared with observations and a threshold value for the forecasts was set. At the moment there is no concentration limit or standard for visible HABs. In Publication V the limit was set to be $2 \mathrm{mg} \mathrm{m}^{-3}$ based on the relevant literature (Kutser 2006, Mazur-Marzec 2006) and uncertainties in nitrogen-chlorophyll conversion. To calculate the amount of cyanobacteria in chlorophyll-a, the special C:N and C:Chla ratios were used.

\subsubsection{System verification methods}

The representability of the SST ensemble distributions, as well as the quality of the ensemble forecasts were verified by the three methods: the rank histogram, the continuous rank probability score (CRPS) and residual-quartile-quartile (R-Q-Q) method. The quality of the upwelling forecasts are then verified by probability of detection (POD) value and false alarm rate (FAR) value.

\section{Rank histogram}

In Publication IV, a rank histogram was used to compare the ensemble SST distribution with observation distribution. The observation data was from Northern Baltic Proper wave buoy (Section 2.3.1). A rank histogram (Anderson 1996, Hamill and Colucci 1997, Talagrand 1999) is probably the tool most used for analysing ensemble forecasts (Jolliffe and Stephenson 2003). The histogram is useful in determining the reliability of an ensemble forecast and as a diagnostic tool for analysing the mean and spread. The method has been proven applicable for forecast verification. However, it should be used carefully with other verification methods to ensure the forecast quality. In general, a flat histogram means that the spread of the ensemble covers the spread of the observations and the distributions are indistinguishable and thus have an ideal rank uniformity (Wilks 2011). The differences from the ideal rank uniformity can be used to analyse the inefficiencies of the ensembles. However, there are caveats which are presented in depth by Hamill (2001). 


\section{CRPS}

In Publication IV, CRPS method was used to evaluate the SST ensemble forecasting system. The observation data for comparison was from a Northern Baltic Proper wave buoy (see Section 2.3.1). CRPS can be interpreted as an integral over all possible Brier scores (Jolliffe and Stephenson 2003). For deterministic forecast CRPS is equal to the mean absolute error (MAE) and thus allows clear interpretation (Hersbach 2000, Wilks 2011).

CRPS is defined as follows, where $x$ is the parameter of interest (e.g. SST) and $x_{a}$ is the value that actually occurred:

$$
C R P S=\int_{-\infty}^{\infty}\left(F(x)-F_{a}(x)\right)^{2} d x
$$

where

$$
F_{a}(x)= \begin{cases}0, & \text { if } x<\text { observed value } \\ 1, & \text { if } x \geq \text { observed value }\end{cases}
$$

and $F(x)$ is the forecasted probability that $x_{a}$ will be smaller than $x$.

\section{The $R-Q-Q$ method}

The R-Q-Q method is a graphical tool for analysing if two datasets have a common distribution. This method was used in Publication IV to compare SST ensemble distribution with wave buoy observations (see Subsection 2.3.1). The $\mathrm{R}-\mathrm{Q}-\mathrm{Q}$ method is similar to Quartile-Quartile plot, but instead of plotting the forecast quartiles versus observation quartiles, it plots the difference or "residual" of the two quartiles on the $y$-axis. The R-Q-Q plot graphically compares data with the reference distribution and is sensitive to differences in mean and variance between the forecast and observations (Marzban et al. 2011, Wilks 2011).

\section{$P O D$ and FAR}

In Publication IV the performance of the upwelling forecasts is estimated with numerical values called POD and FAR (Donaldson et al. 1975) using contingency table (Table 2.2).

The probability of the event depends on the selected threshold value for the studied phenomenon. The observation is "true" when the threshold limit is exceeded, and the same is valid for the forecast. 
Table 2.2 Contingency table for defining POD and FAR

\begin{tabular}{|c|c|c|c|}
\hline & \multicolumn{2}{|c|}{ Observation } \\
\hline & & True & False \\
\hline \multirow{2}{*}{ 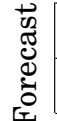 } & True & $\mathrm{a}$ & $\mathrm{b}$ \\
\hline & False & c & $d$ \\
\hline
\end{tabular}

The POD and FAR values can then be defined as follows:

$$
P O D=\frac{a}{a+c},
$$

and

$$
F A R=\frac{b}{a+b}
$$

respectively.

In Publication IV the upwelling forecasts are evaluated with this method by setting the threshold value of SST change to be at minimum $1^{\circ} \mathrm{C} /$ day. The observations used for the evaluation are from satellite tide gauges (see Section 2.3.1).

\subsubsection{Illustration of the probabilities}

Ensemble forecasts contain a large amount of information. Compared to deterministic forecasts, the interpretation and communication of the uncertainties are more challenging. In Publications IV and V these issues were approached with different types of figures, which show, for example, the spread of the ensemble members and the probability of different events.

In Publication IV the results were illustrated with plumes (Figure 7) and with quartile plots for a single point (Figure 5). In addition to Ensemble Prediction System (EPS) plumes of temperature, the upwelling phenomenon was studied with violin plots of the time derivatives of the variable. Violin plots combine a box plot and kernel density (Hintze and Nelson 1998). White dots inside the plots indicate the median value. In general, violin plots give more information than box plots, especially when working with skewed distributions. Since forward differentiation was used to calculate the temperature derivative the violin plots are one day shorter 
than the EPS plumes. This method allows examination of the temperature change distribution more closely and identification of the possible upwelling events.

In Publication V the HAB probability maps were presented and compared with Alg@line data and a map based on visual observations (see Section 2.3.1).

\subsection{Validation data}

\subsubsection{Observations}

\section{CTD data}

CTD data was used in this study (in Publications I and II) to compare the Argo results in the Bothnian Sea with existing and established hydrographical results. The CTD data is typically measured from the research vessel during monitoring cruises (COMBINE). Finland is responsible for monitoring the hydrography of the Bothnian Sea together with Sweden. The implementation of the CTD measurements is described more closely by HELCOM (2017).

CTD data was measured on the Finnish research vessel $R / V$ Aranda in the Bothnian Sea during 1998-2017. A Seabird CTD has been on board Aranda since 1997, and thus this 20-year measuring period is considered to be consistent in terms of measurement set up and errors. The average number of CTD profiles per month was three for 1998-2017 and two for 2012-2017, although it greatly varied, depending on monitoring and research campaign timing, with about four months in a year having no measurements.

\section{Tide gauges}

Tide gauges measure the water level as well as water temperature around the Finnish coast. The data used in Publication IV was 10-minute data which was averaged over 24 hours. The tide gauge data was used to analyse the water movements in the Bothnian Sea basin (see Publication III) and the sudden decrease of temperature during the upwelling events (see Publication IV). Further details of the tide gauge data and methods 
were given by Johansson et al. (2001).

SST from a wave buoy

For general analysis of the performance of the ensemble forecast system (see Publication IV), the wave buoy measurements of SST from the Northern Baltic Proper (59 $15^{\prime}$ N $21^{\circ} 00^{\prime}$ E) were used. Further information on the data from the buoy can be found in the work of Kahma et al. (2003). The buoy measurements were taken every half an hour and averaged over 24 hours.

\section{Satellite data}

Satellite SST observations were used to identify the upwelling events in Publication IV. This dataset was based on data from the National Oceanic and Atmospheric Administration (NOAA) AVHRR satellite. Each image was processed using a split window method and cloud detection algorithm at SYKE (Finnish Environment Institute) (SYKE 2015).

\section{Alg@line data}

The biomass data from the Alg@line project (Ruokanen et al. 2003) was used to compare forecasted HABs with observations in Publication V. The data was collected by ferries operated by shipping companies. The ferries have a flow-through system called Ferrybox, which is equipped with GPS, thermosalinograph, chlorophyll, phycocyanin and coloured dissolved organic matter (CDOM) fluorometers, a turbidity meter and a refrigerated sampling unit.

\section{Wind observations}

Wind observations from weather stations around the Bothnian Sea and the Baltic Sea Proper were used in Publications I, II and III to analyse the effects of the wind on the sea. The stations are administered by the Danish Meteorological Institute (DMI), the Swedish Meteorological and Hydrological Institute (SMHI) and FMI and the average wind is calculated by the governing institute. 


\subsubsection{D hydrodynamic model data}

For comparing estimated velocities from floats in the Bothnian Sea (see Publication III) and analysing surface drift errors, the two nautical mile (NM) set-up of the NEMO 3D ocean model (V3.6), covering the Baltic Sea and North Sea area, was used. The model wasrun from June to December 2014 (Hordoir et al. 2013, 2015, 2018).

The vertical resolution of the NEMO set-up was $3 \mathrm{~m}$ on the surface, and layer thickness increased with depth. There were altogether 56 layers in this configuration. The time step of the model was 15 minutes and the results were saved as one day averages. The bathymetry of the set-up was updated to the latest version of the NEMO Nordic bathymetry . The more detailed description of the bathymetry in this model setup can be found in Hordoir et al. (2018). River run-offs and precipitation fields were climatological. The atmospheric forcing for the model was achieved from the FMI numerical weather prediction system HIRLAM (HIRLAM-B 2015). Forcing was read into NEMO with the CORE bulk formulae (Large and Yeager 2004). 


\section{Results}

\subsection{Hydrographical measurements}

\subsubsection{A general description of the hydrography in the Bothnian Sea}

In Publication II the Argo measurements were used for the years 20122017 in the Bothnian Sea (Table 3.1 and Figure 3.1). During this period the ice avoidance algorithm was tested but not used in real ice conditions.

The near surface ( $4 \mathrm{dbars}$ ) temperatures varied from $0.1^{\circ} \mathrm{C}$ to $22.7^{\circ} \mathrm{C}$ and salinities from $4.18 \frac{g}{\mathrm{~kg}}$ to $5.74 \frac{\mathrm{g}}{\mathrm{kg}}$. The deep measurement depth studied was 100 metres, since it is the deepest HELCOM standard depth and it is always below the estimated halocline depth. The monthly mean temperature in this depth varied from 3.6 to $4.5^{\circ} \mathrm{C}$ and the monthly mean salinity varied from 6.24 to $6.47 \frac{g}{k g}$ (see Publication II, Figure 3).

The mean temperatures measured with Argo floats closely followed the mean temperatures presented in earlier studies (Lentz 1971). There were some differences, for instance, the summer mean temperature was a couple of degrees warmer and bottom temperature variation was smaller.

On average, the salinity was also close to values found in the related literature both near the surface and below the halocline. However, the variation appeared to be smaller than in the literature and the measured values in general were at the lower end of the range found in the literature. 


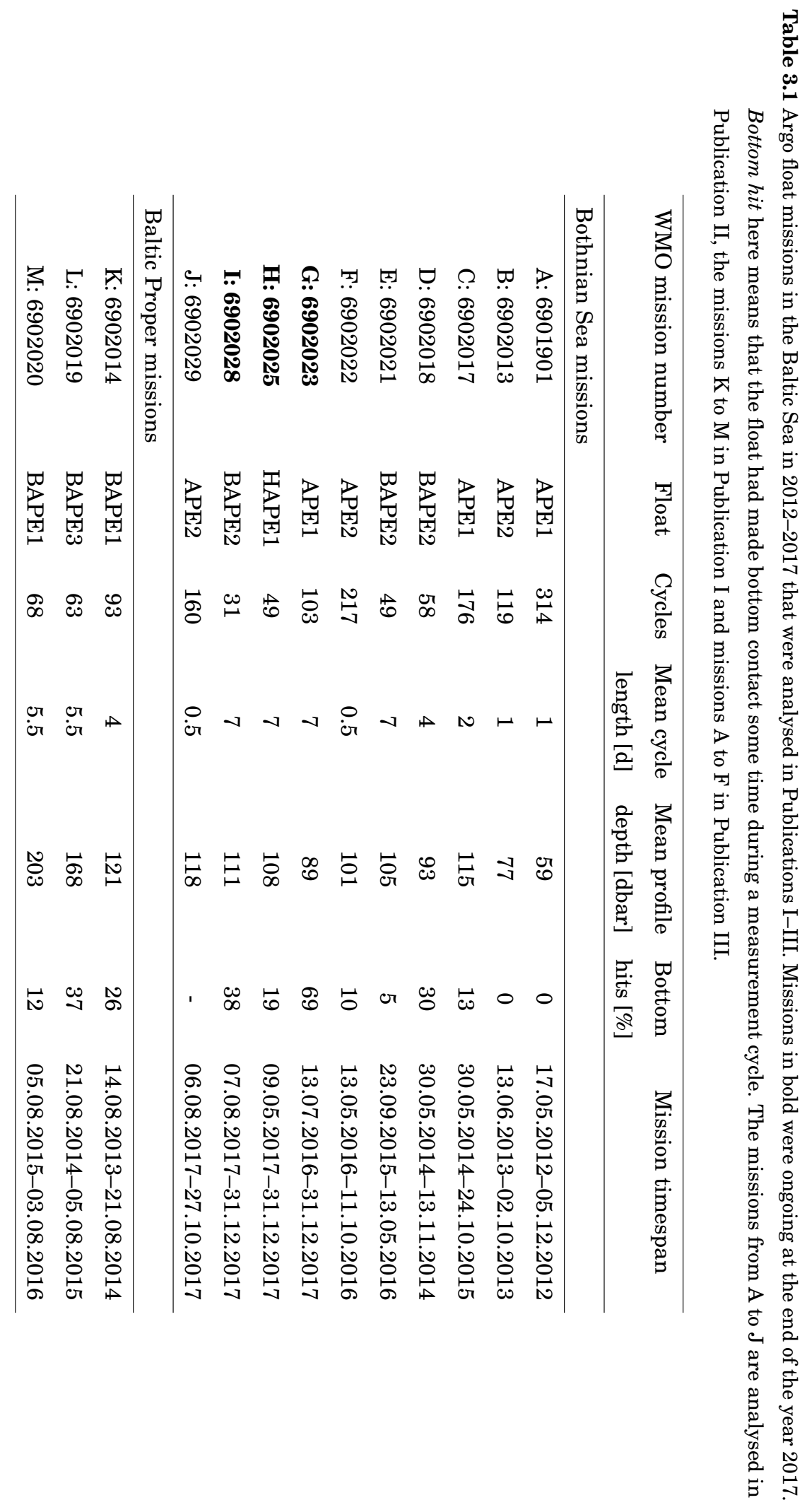




\subsubsection{Small-scale events}

In Publications I and II an Argo floats' ability to measure three small-scale hydrographical events was showcased. The timescale in all three events was in order of days and the spatial scale of an order of kilometers. The first two cases were rapid wind-mixing events on the surface layer that took place in the Eastern Gotland Basin and the Bothnian Sea. The third event was the detection of warm water lenses in the Bothnian Sea, which were potentially caused by a wind-induced downwelling event.

\section{Warm water lenses}

Two lenses of relatively warm water were measured under the halocline at a pressure between 60 and 100 dbars after 15 October 2017 (see Publication II, Figure 8). The temperature in these lenses was $1.3^{\circ} \mathrm{C}$ warmer than the surrounding water mass. The event could be seen in the measurements for ten days. During the event the float drifted approximately nine kilometres. This event was probably caused by hard NW-NE winds between 5-10 October, which had triggered a downwelling event on the western side of the Bothnian Sea.

Two missions, Missions I and J (Table 3.1), were measuring during this period, the latter having a high measurement frequency ranging from two hours to 24 hours and the former having a low measurement frequency set to seven days. The aforementioned lenses could be detected by Mission J with the higher measurement frequency, but were either missed completely or their durations and magnitudes were not fully captured by Mission I with a measurement cycle of a week.

\section{Wind-induced mixing in the surface layer}

In the Eastern Gotland Basin the formation and the decay of the thermocline were detected from the temperature and salinity measurements made in Mission K (Table 3.1). Publication I presents an event that occurred in the autumn of 2013 when the hurricane-class storm "Christian" crossed the Baltic Sea Proper in October 28. The maximum 10-minute average wind speed measured during the storm was $39.5 \mathrm{~m} / \mathrm{s}$ in Denmark. From 28 to 29 October the wind speed varied from 17.4 to $22.1 \mathrm{~m} / \mathrm{s}$ at the Östergarnsholm weather station, on the Gotland Island. This weather station was the closest station to the Argo measurement area. Also, the maximum significant wave height measured by the Northern Baltic Proper 
wave buoy was 5.2 metres. The float's measurement cycle lasted five days at that point. Figures 10 and 11 in Publication I show how the strong thermocline eroded during the storm between the measurements on the 24 and 29 October.

Mission J (Table 3.1), at the end of October 2017 in the Bothnian Sea was set to measure a profile every two hours to capture a storm event (see Publication II, Section 3.2). During the storm the thermocline deepened 10 dbars, changing from 30 dbars to 40 dbars, and the uppermost surface layer Argo measurement cooled by $0.9^{\circ} \mathrm{C}$ during the 24 -hour period. The storm event was seen from the weather forecasts well in advance and the profiling mode was changed before the storm reached the studied area.

\subsubsection{Estimation of currents}

In Publication III the currents in the Bothnian Sea with Argo floats were analysed. There were altogether six Argo float missions during the years 2012-2016, which used three different floats (see Table 3.1). Five missions were launched at the beginning of summer (between mid-May and midJune), and one mission was launched in September. The deployment of the floats took place near the same location in the middle of the Bothnian Sea deep (Figure 3.1). This was to avoid bottom contact and collisions with other vessels. During the winter time, the ice avoidance was also tested.

In Publication III the currents in the Bothnian Sea, measured with Argo floats, were analysed and methods for surface drift estimation were presented with both drifting measurements and hydrodynamic model estimates.

\section{A general description of the currents in the Bothnian Sea}

The mean distance the float moved during a one measurement cycle was two to three kilometres. The average current speed was $2 \mathrm{~cm} / \mathrm{s}$, which is considered to be an average residual speed in the deep waters (Alenius 1993). High speeds over $10 \mathrm{~cm} / \mathrm{s}$ were very rare, and only estimated to occur in $3 \%$ of the cases, in fairly shallow depths. The majority of the floats' trajectories followed the expected resultant current towards the north (Publication III, Figure 7). 
The speed estimates were compared with the current velocities calculated by the NEMO model (see Section 2.3.2). At each profile point the corresponding grid point from the model domain was chosen. The model run took place from June to December 2014 (altogether for seven months). The results from the float and the model were not directly comparable because the time scale of the events suitable for investigation by the NEMO model was limited by the structure of the model configuration and available inputs for the model. To be able to assess the magnitude of the velocities the velocity distributions from the model and observations were compared (see Publication III, Figure 4).

In the modelled period from June to December 2014 there were three occasions when there were strong winds and the float's drift speed exceeded $7 \mathrm{~cm} / \mathrm{s}$ during the measurement cycle (see Publication III, Section 3.1). On the two first occasions presented in Publication III, the current speeds modelled by NEMO and estimated from Argo trajectories represented the highest $5 \%$ of the current speeds in that time period. Because of this, both Argo and model current speed estimates were considered to be exceptionally high during these events. On the last occasion the wind direction was southward and there were no clear signals of higher current speeds in the model results, even though the observations suggested strong currents.

The possible sources of differences between the model results and observation could be, for example, related to weather forcing. It was possible that the routes of the low pressure systems were not described exactly by the weather models. It was also possible that the float had drifted on the surface longer than expected. The bathymetry was poorly known in the area and that could cause differences between the model and observation.

\section{Currents in the Bothnian Sea Deep}

In Publication III the currents in the Bothnian Sea Deep were analysed (see Figure 3.1). On average, the floats drifted in the deep in 106 dbar pressure, which is 13 dbars more than the average of all Bothnian Sea measurements. The maximum pressure was 126 dbars. The speed estimated from float movement was on average $2 \mathrm{~cm} / \mathrm{s}$, which is in accordance with the whole of the Bothnian Sea results (Alenius 1993), and the temporary maximum was $13 \mathrm{~cm} / \mathrm{s}$ (see Figure 3.2b). The main directions of the currents ran along the north-south axis, with the major part of observations showing a northward 


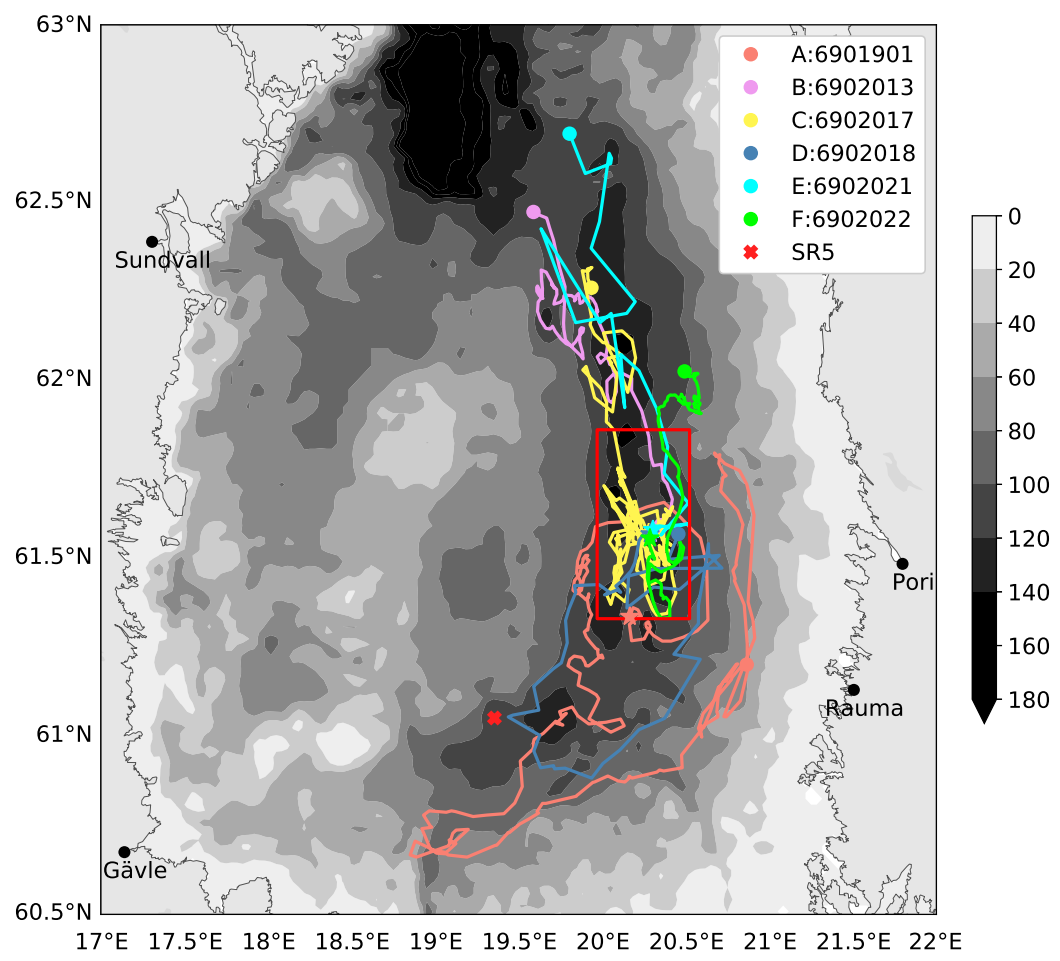

Figure 3.1 Argo missions in Bothnian Sea deep area. There were altogether 257 measurement cycles analysed for this study. The bathymetry is shown in greyscale and the studied area is marked with red box. The routes of the missions are marked with other colours.

movement. The $\mathrm{N}-\mathrm{W}$ to $\mathrm{N}$ sector covered $37 \%$ of all the observed directions, while the sector from S-S-W to S-S-E covered around $22 \%$ of all directions (Figure 3.2a).

The Bothnian Sea deep was gridded and the persistence for the different grid boxes was analysed as described in Section 2.1.2. The persistence varied from $17 \%$ to $96 \%$ in the grid boxes that had over eight measurements. It was common that the measurements in the same grid box were more or less consecutive, therefore synoptic-scale weather phenomena could explain the high persistency value. 


\subsection{Monthly ensemble forecasts}

\subsubsection{Forecasting upwellings}

In this study the interest in upwelling forecasts was in regard to timing. If the timing of the event is known, it is possible, for example, to forecast fogginess in a coastal area. The monthly scale forecast can then be refined to shorter-term forecasts in order to have a closer look at the event. In Publication IV SST forecasts were produced for the Baltic Sea. These forecasts were then analysed and a threshold value for the upwelling event was defined (see Section 2.2.2). The forecasts were then verified by using the methods described in Section 2.2.3. The forecast was evaluated to be successfull if the cooling period in the forecast started during the upwelling event in observations (see Section 2.3.1).

Altogether there were 13 measured upwelling events, which could be detected on one or more of the eight tide gauges during the study periods between 2008 and 2009. The forecasts were divided into three categories: forecasts of up to seven days, forecasts ranging from seven to 14 days and forecasts for over 14 days. The shortest forecast period predicted 11 upwelling events, the second six and the longest two.

The POD value (see Equation 2.4) was $84.6 \%$ for the shortest forecast, $46.2 \%$ for the two-week forecast and $15.4 \%$ for the more-than-two-week forecast. The FAR value (see Equation 2.5) from all forecasted events was $15.4 \%$ for the up-to-a-week forecast, $68.4 \%$ for the two-week forecast and $84.6 \%$ for the longest forecast. For the shortest forecast period, the ratio of detected upwelling events was high and there were very few false alarms. As the forecast period extended POD decreased and FAR increased. According to these results the longer-than-two-week upwelling forecasts had only little skill.

\subsubsection{Forecasting harmful algal blooms}

In Publication $\mathrm{V}$ one case study was made to show whether it is possible to produce quantitative $\mathrm{HAB}$ forecasts with the aforementioned ensemble prediction system. Figure 3.3 shows an example of a monthly ensemble forecast of the amount of cyanobacteria and SST on the east coast of the Gotland Island. The algae situation was measured 10 days earlier by 
Alg@line, showing a blue-green algal biomass on enroute from Helsinki to Travemünde (see Publication V, Figure 5). The amount of algae biomass was significantly lower on the east coast of Gotland, which implies that there was a possible ongoing upwelling event. The lower cyanobacteria biomass concentrations observed near the coast were captured by a large number of ensemble forecast members (see Figure 3.3b). Also, the forecasted SST results implied an upwelling event in the area (see Figure 3.3a).

The two-week harmful algal probability forecast made on 10 July 2008 (see Publication V, Figure 7) was also compared with blue-green algae visual observations collected by Finnish Institute of Marine Research from 22-24 July 2008 (see Publication V, Figure 6). It could be seen that in many areas in the Gulf of Finland, where a high probability of HABs were forecasted, there were also several observations of HABs. On the other hand, in the Baltic Proper the HABs were observed on the western side of the Gotland island when the forecasted higher probability of the blooms was on the eastern side. Also, there were HAB observations in the Archipelago Sea, but the forecast gave low probabilities of HABs.

\subsubsection{Verification of the forecasting system}

Verification deals with the functionality of the forecasting system to assess, for example, if the system produces forecasts that accurately represent the distribution of real-world events. Usually, the information about the error and its change as a function of the forecast length is wanted. These questions were studied with two methods used widely in meteorological applications (see Section 2.2.3).

A SST rank histogram that combined monthly ensemble forecasts from 2008 and 2009 showed that the temperature observations from the Northern Baltic Proper wave buoy tended to fall in the lower bins than was statistically expected (see Publication IV, Figure 2). The histogram indicated that the system was slightly biased. The rank histogram also showed that the spread of the ensemble did not cover enough of the future possibilities and many observations tended to fall outside of the forecast plume.

CRPS showed that the error between the SST observation and the ensemble grew as the span of the forecast grew (see Publication IV, Figure 3). On 
average, the error between the forecast and the observation tended to grow by around $0.01^{\circ} \mathrm{C}$ per forecast day. The initial error between the model and the observation was $0.66^{\circ} \mathrm{C}$, which is in line with the other verifications made for this model before. The variation in temperature between months was quite large, as was also detected from the in-situ measurements (see Publication IV, Figure 4). In general, it was possible to see the growth rate for error during the monthly forecast from CRPS. Despite this, CRPS is a single quantity from which is difficult to see the detailed behaviour of the forecasting system (Hersbach 2000).

The R-Q-Q plot for the SST data (see Publication IV, Figure 5) showed quartile distribution to be somewhat S-shaped, which indicated similar issues to those of the rank histogram: the spread of the ensemble was probably too narrow, and minimum and maximum values were not well produced by the system. The positive slope suggested that the SST variations within the ensembles were larger than within the observations. 


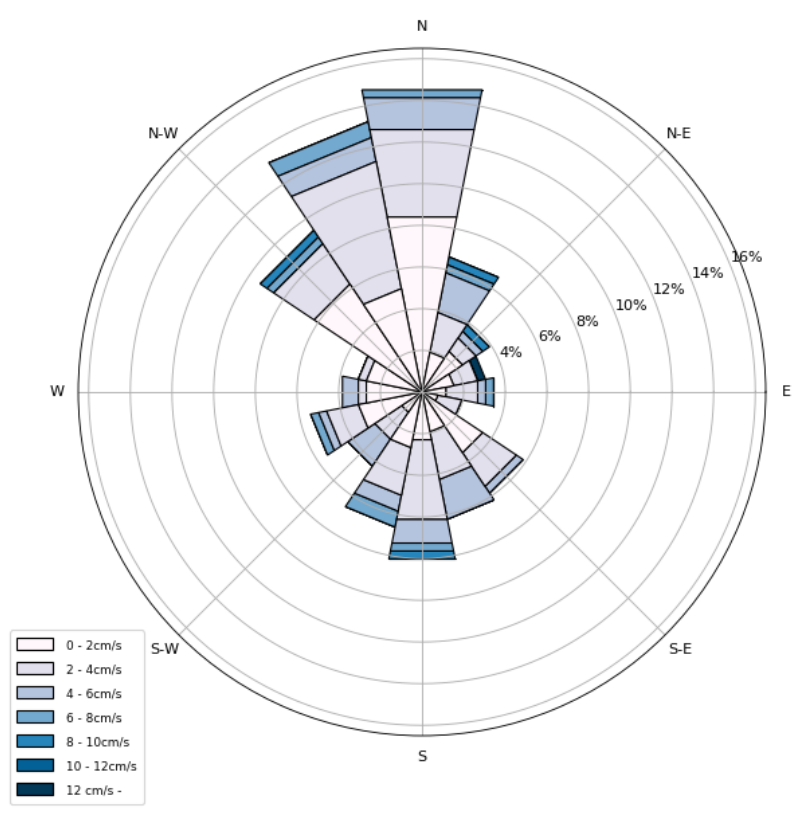

(a)

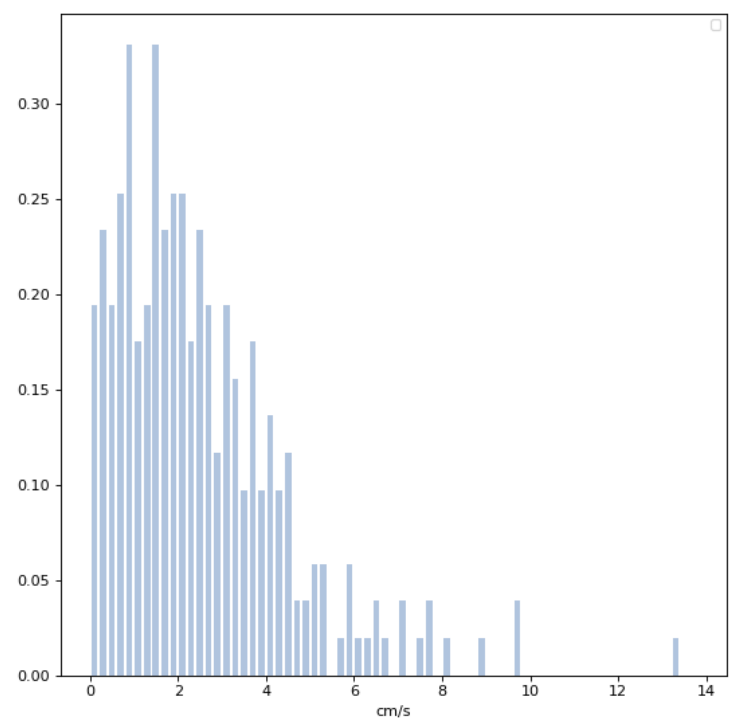

(b)

Figure 3.2 The current rose (a) and probability density histogram (b) showing the directions and distributions of the current speed in the Gulf of Bothnia Deep for Apex Missions A-F (Table 2.1). The figures are drawn from the data in Publication III. 


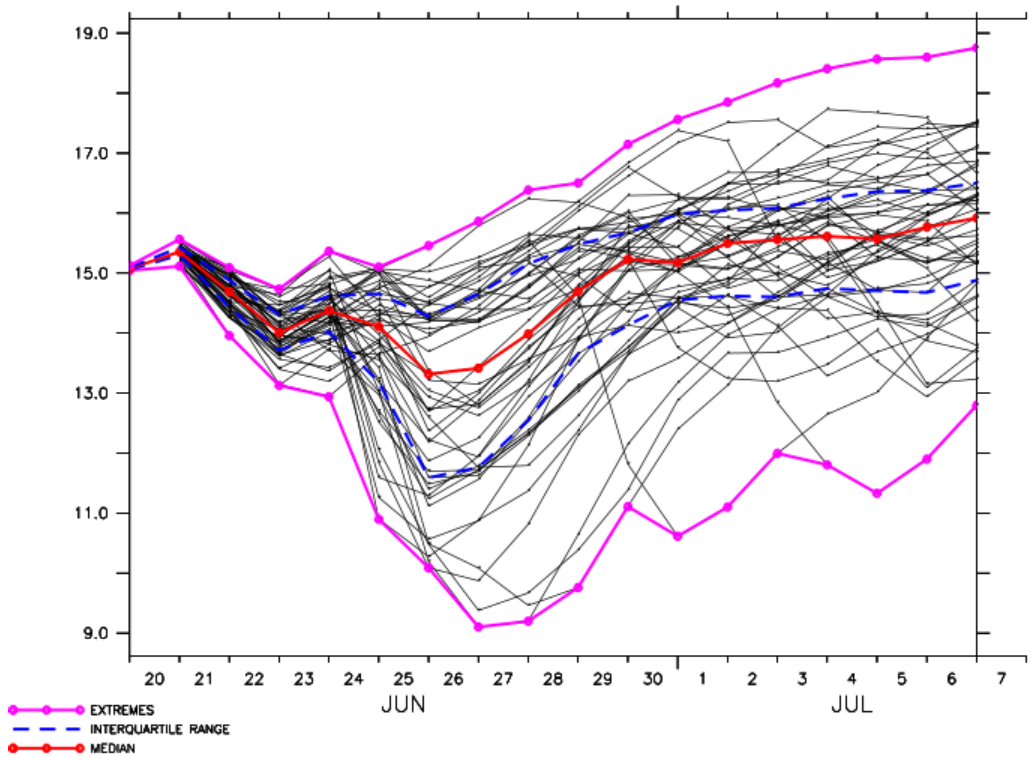

(a) Sea surface temperature $\left({ }^{\circ} \mathrm{C}\right)$

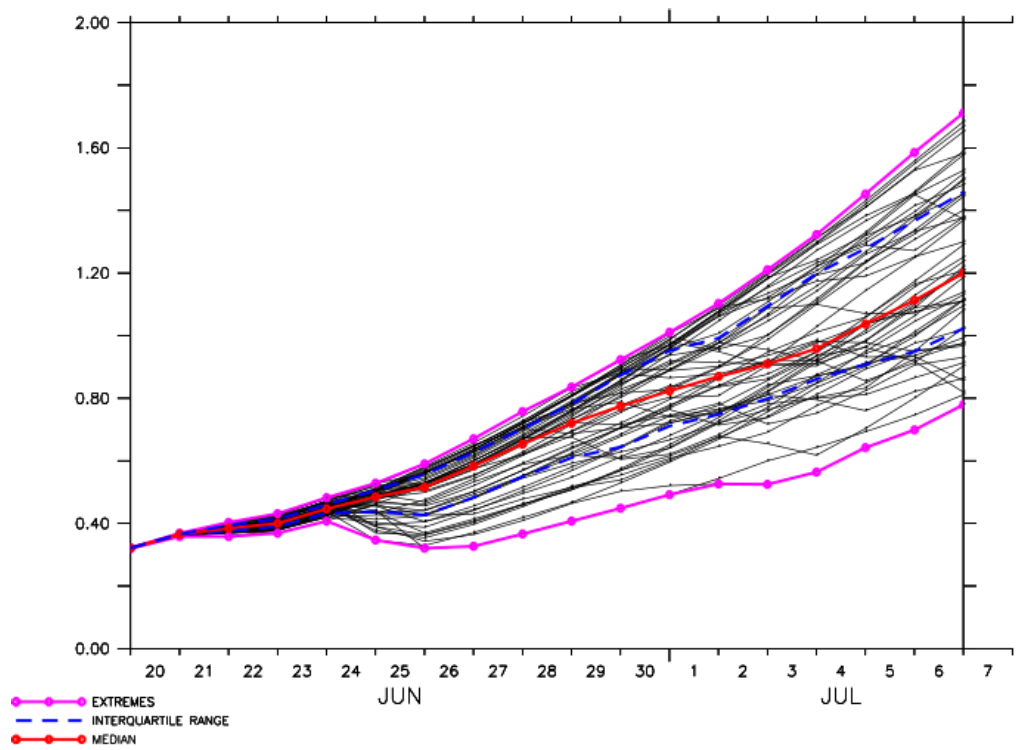

(b) Amount of cyanobacteria $\left(\mathrm{mg} \mathrm{m}^{-} 3\right)$

Figure 3.3 An example of the monthly forecast predicting SST (a) and the amount of cyanobacteria (b). The forecast is made for the east coast of Gotland island $\left(18.10^{\circ} \mathrm{E} 57.25^{\circ} \mathrm{N}\right)$ beginning from 20 June 2008 and ending 7 July. In the SST forecast upwelling event can be seen on 24 June. Figures (a) and (b) are from Publication V 
Results 


\section{Discussion}

\subsection{The developments of the operational system}

In this work methods were developed for extending the possibilities of the operational systems of the northern Baltic Sea. These improvements are focused on the new methods for observing the Baltic Sea with autonomous Argo floats, as well as on the new monthly ensemble forecasting methods, described in the previous sections. The observational and computational methods provide a more complete understanding of the state of the sea in the present moment and also in the short- and long-term future. The connections between observations and models in the operational oceanographic system are shown in Figure 1.3. The methods presented in this work could contribute together to further improve operational oceanographic system in the Baltic Sea.

The measurements and the prediction methods can be used side by side so that the observations work as the basis of the hydrodynamic models that provide information on marine conditions for the initialisation and assimilation, as well as the validation and verification of the system's functionality (see, e.g. Le Traon 2013). Vice versa, the modelled results can be used for planning the observational network (Grayek et al. 2015).

Argo floats are widely used in the oceans. In this study the focus was on three aspects of the measurements taken by autonomous floats in the northern parts of the Baltic Sea: 1) piloting the floats in the Baltic Sea, 2) measuring and monitoring with the Argo floats and 3) analysing and using the GPS data further. 
Argo floats' strength compared to the ship-borne observations is that they are able to catch the seasonal variations of the temperature in the nearsurface layer, as well as the thermocline strength, due to the fact that they frequently measure during the summer when the peak temperatures appear. With the new automatic and real-time observations, it is possible to fill in some of the gaps in our understanding of the state of the sea, especially in regard to the temporal and spatial scales that are important to the biogeochemistry of the sea (McGillicuddy 2016). Combined with other methods, it is possible to make a closer study, for example, about climate change and its effects on a local scale. Sufficiently large amount of data from Argo floats could be combined with satellite data to create 3D observation field from the sea and use that as an initial field for models, in data assimilation or validation of the models. With the floats it is also possible to observe temperature and salinity changes in the deep layers and study the changes in stratification. This type of studies could be then combined with biogeochemical analysis of nutrient availability, upwellings and gas exchange, to name but a few examples.

The salinity range in both horizontal and vertical directions are, so far, better captured with the traditional CTD than the Argo measurements. There exists a horizontal salinity gradient in the Bothnian Sea which can be better observed with shipborne measurements than with Argo floats. The range of research ship operations is not limited by bathymetry and currents in the same manner as the trajectories of the Argo floats are. However, we can utilise the free-floating feature of the Argo floats to estimate water movements.

With ensembles the uncertainties of the forecasts can be shown and discussed in more detail. The upwellings have a great local impact on the marine environment as they change the physical conditions rapidly and bring nutrients to the euphotic zone (see, e.g. Lehtoranta et al. 2017). Upwelling events cool the surface water and affect the local weather (Sproson and Sahlée 2014). Prediction of these phenomena well in advance can help to serve society by increasing safety (see, e.g. Tonani et al. 2015, Hobday et al. 2016).

Society benefits from these aforementioned improvements. Hobday et al. (2016) showed that in the marine businesses there is a need for different forecast time spans ranging from nowcasts to climate-scale forecasts. The observations are an essential part of the operational systems as the data 
has numerous uses, as discussed in this work. The real-time observations tell the current status of the sea, and historical data sets reveal the changes in the marine environment. By knowing and understanding the hydrographical conditions in the sea, the alleviation of the negative human impact on the environment is possible.

\subsubsection{Observational methods}

Argo floats can measure the salinity and temperature profiles and currents at the diving depth on a temporal scale of hours. In the Bothnian Sea the time scales for current estimates need to be evaluated carefully, because the surface drift becomes dominant in very short cycle lengths. The surface currents affect floats' movement and the exact amount of the surface drift remains unknown. The order of magnitude can be estimated already, but in the future, the methods for removing the surface currents from the results can be developed. The methods for removing the surface drift could be, for example, to record the location more often while on the surface. The methods for evaluating the effect of mesoscale events on temperature and salinity observations, as well as on trajectories, are developed for the North Atlantic by simulating the Argo array with a numerical model (Kamenkovich et al. 2011). This implies that there is a growing need for careful planning of missions. The best and densest measurement interval for scalar measurement in the water column, such as temperature and salinity, is probably not the best for the vector measurements, such as velocity, as the portion of the surface drift increases.

With Argo floats it is possible to measure the water column in the deep areas of the Baltic Sea. In the Bothnian Sea's and Gotland Sea's deeps, the currents keep the floats in the same area and away from the coast, which extends the mission length. However, this also limits the use of the Argo floats, as they do not move actively so they cannot be directed anywhere else than where the winds and currents move them, and thus in practice, they cannot measure the whole basin. On the temporal scale the measurements cover a whole year cycle. So far the winter measurements have been sparse and the ice-avoidance technology has been tested. However, in the oceans the Argos are routinely measuring under ice (Wong and Riser 2013) and the test results from the Bothnian Sea and Bothnian Bay floats are promising. 
The Argo drifting depth is decided by the pilot. This decision is typically based on marine charts and the available bathymetry. Unfortunately the existing data for remote areas is sparse and sometimes inaccurate. This leads to collisions with the bottom and some unknown distance between the bottom and the drifting depth is not included in the profile measurements. Also, the surface data is not available due to the present sensor technology, which shuts the CTD pump down at approximate 4 dbar pressure.

The Argo data sent is real-time quality controlled (RTQC) by Coriolis Argo data centre (http://www.coriolis.eu.org). This procedure is similar with deep ocean Argo data. The delayed mode quality control (DMQC) methods for the deep ocean Argo data matured during the Argo project and their purpose was to ensure that the data was free from all detectable errors and biases (Gaillard et al. 2009). However, the DMQC methodology for Argo data from shallow, marginal seas is still under development.

With Argo floats it is possible to collect spatially and temporally dense observation series, which could contribute to climate modelling. Balmaseda and Anderson (2009) concluded that all the available data from ocean observing systems contribute to the skill of the seasonal forecast when used for initialising the forecast.

\subsubsection{The ensemble forecasting system}

Ensemble forecasts are a computationally time- and storage space-consuming way of forecasting. Compared to deterministic forecasting it is possible to gain more information about the uncertainties, but the price in this case is that the computational time and storage space needs are 50 times larger than those required for a deterministic forecast. This is also something to consider when planning to have more dense computational grids and more computationally intensive methods.

The ensemble forecasting system was analysed in Publication IV. From those results we may assume that there are some limitations to the forecasting system. The produced ensembles are somewhat too narrow so they do not detect all the events. There are some possible explanations for this: the initial conditions of the sea do not include information about the errors in the initial values. Therefore the forecast cannot take into account this uncertainty about the initial state of the sea. Also, too large vertical mixing together with a coarse resolution, can potentially cause, for example, 
incorrect forecasting of the formation of the sub-thermoclines during the summer and therefore only the large-scale features of the upwelling events can be detected. According to the results of the Leutbecher (2018) the number of ensemble member in this study can be regarded to be sufficient for operational purposes.

The wind forcing has a great impact on the quality of the ocean forecasts globally and the quality of the atmospheric forcings should be also improved (Treguier et al. 2017).

\section{Resolution}

Since the upwelling as a meso-scale phenomenon is also scaled by the baroclinic Rossby radius, the grid size should be of such an order (or even finer) (Lehmann and Myrberg 2008). Andrejev et al. (2011) and Lindow (1997) showed that the resolution for hydrodynamic models should be in order of half or even one-third of local baroclinic Rossby radius. In this study the spatial resolution of the BALECO model was $6 \mathrm{NM}$ (around $11.1 \mathrm{~km}$ ), which is in the upper limit of the baroclinic Rossby radius in the Baltic Sea (Alenius et al. 2003), and therefore the phenomena were not described to their full extent. However, as the purpose of this work was not to study the upwelling as such but to study the ensemble prediction system, the resolution was considered to be suitable as it was able to predict upwelling events, although the extent and magnitude were not fully described. To be able to produce mesoscale phenomena in detail in the Bothnian Sea the horizontal resolution should be in order of $1 \mathrm{~km} \times 1 \mathrm{~km}$.

\section{The threshold limits for probability forecasts}

In Publication IV the threshold limit for an upwelling was set to be $1^{\circ} \mathrm{C} /$ day (Lehmann and Myrberg 2008). On the one hand, it is unlikely that such a change in temperature would be produced by other phenomena, such as cold air advection, especially during the summer. On the other hand, this limit is still low enough to assure that important upwelling events are not missed.

In Publication $\mathrm{V}$ the chlorophyll-a concentration threshold value was set to $2 \mathrm{mg} \mathrm{m}^{-3}$ as a limit for a potentially visible cyanobacterial occurrence. In practice there is no such limit or standard, especially because the HAB observations are based on visual approximation. However, some studies have measured the chlorophyll-a concentration during a cyanobacterial bloom. 
Kutser (2006) suggested that blooming can be defined as a chlorophyll-a concentration exceeding $4 \mathrm{mg} \mathrm{m}^{-3}$. Mazur-Marzec (2006) found that the chlorophyll-a concentration was about $10 \mathrm{mg} \mathrm{m}^{-3}$ or more during blooming in the Gulf of Gdańsk in the summer of 2004. However, Karlson et al. (2008) did not find any correlation between satellite based observation and microscope analysis of the cyanobacteria accumulations. In this work the evaluation was based on the best available operational HAB data of the area, which was composite of satellite and visual data, therefore including uncertainties from the both datasets. Taking into account the uncertainties in the nitrogen-chlorophyll conversion, $2 \mathrm{mg} \mathrm{m}^{-3}$ is a conservative limit for a level of biomass that could be perceived as a harmful or nuisance bloom.

\subsection{Future work}

In changing climate, the need for theoretical framework and models which can cope with large amount of data is complementary to dense and highquality observations. Ruhl et al. (2011) concluded that physical parameters can be forecasted fairly well, but even more specific tools are needed, for example, in food web modelling and forecasts for marine ecosystem variables. The ecosystem modelling of the Baltic Sea has not yet reached a state in which it could answer the majority of the requirements for the EU MSFD (Tedesco et al. 2016). Ensemble forecasting systems are an essential tool in operational oceanography, serving numerous purposes such as sustainable blue growth and future planning. In the future extreme weather events will potentially be more common, and therefore, ensemble forecasts can also help mitigate the effects of these events (She et al. 2016).

The observational and computational methods are developing fast. Argo data has already been used to evaluate models in the Bothnian Sea (Westerlund and Tuomi 2016). In the future the computational capacity will increase and that will enable several new improvements, not only in spatial and temporal resolution but also in the computational methods themselves, such as those used in self-organizing maps and machine learning. In the future it is possible to use models with more complex topology and ecological models. This complexity requires better understanding of the processes, as well as better methods for assimilation, improvements of the initial 
fields and also methods for data analysis and management (see, e.g. Dickey 2003, Axell and Liu 2016).

Globally, high quality observations of salinity and temperature are combined statistically with frequent and lower-accuracy satellite measurements to produce 3D temperature and salinity fields at high temporal and spatial resolutions (Guinehut et al. 2012). Furthermore, the combined systems' ability to reconstruct mesoscale phenomena has been evaluated (Barceló-Llull et al. 2018). The ability of the Argo fleet to work as a part of observational systems has also been analysed by statistical methods and models (Grayek et al. 2015). The 3D fields have been tested lately for forecast data assimilation in the Baltic Sea (Axell and Liu 2016).

The measurement and battery technology is developing fast. With the more powerful batteries the floats can carry more sensors, including altimeter to prevent the bottom hits and adjust the diving depth in relation to the bottom. The more frequent GPS connections from the surface help to assess the surface drift. The CTD technology is developing, and it enables achieving temperature and salinity data from the whole water column, from the bottom to the surface. The interconnection with other observational platforms need to be considered. For example, the role of gliders was analysed by Liblik et al. (2016). 
Discussion 


\section{Conclusions}

The measurements are a basis for understanding the sea environment. With models it is possible to take a leap forward and try to understand the sea as a whole. Models can be used for forecasting forthcoming events and states. In real life, there has to be a tight connection between the theoretical framework (the model data) and reality (the observations), and the models help us to see further while the observations root our knowledge in reality as far as it is possible.

Even though the observations create the ground truth for all marine analyses, it must be pointed out that observations also have limitations. Measurements do not cover the whole sea and the data has systematic and random errors. The magnitude varies from method to method. This work presents the sources of the uncertainties in Argo observations as well as in forecasts.

The new floats fill the gaps in the observational network of the Baltic Sea in the remote areas. It is possible to achieve observations of small-scale phenomena including high speed currents, and salinity and temperature anomalies in the water columns. With these measurements it is possible to study extreme and/or short-term events that could not have been detected with traditional measurement devices and/or measurement frequencies or with relatively low costs. The floats can be used also for monitoring conditions in the sea and for detecting changes in yearly and, in the future, in decadal scale. The extreme events can be observed during the bad weather that commonly prevents traditional ship-borne observations.

In this thesis new data for analysing the deep currents in a fairly shallow and stratified sea with a non-stationary deep water drifter was used and analysis methods were developed. The results showed that the current estimates from the Argo data produce values on the same magnitude as 
the values with traditional measurement devices. Furthermore, from the Argo data it is possible to detect and analyse the circumstances in which the current speeds were exceptionally high as well as analyse the current field in the deep areas with some limitations.

In this thesis, probability-based forecasting for upwelling phenomena was presented and the length of reliable forecasts were analysed. The analysis showed that up-to-a-week forecasts were accurate and detected large upwellings almost every time. In the longer forecast range the predictability of the forecast deteriorated and the over two-week forecasting system presented in this study was very weak for detecting upwellings.

However, the forecast span of the length of week or more is enough to, for example, prepare for emerging, scientifically interesting events. From the point of view of forecasting, the development of upwelling events and their effect on local weather can be followed more closely.

The hydrodynamics and thermodynamics are important factors of the ecosystem in the sea. As seen in this work, there are a lot of uncertainties in the dynamics alone. The uncertainties in modelling of marine biogeochemistry were studied and an ecological model was used to predict the HABs in the Baltic Sea. The ecosystem model itself had uncertainties added to those in the hydrodynamic model, and therefore many simplifications were made. However, the study showed that it was possible to produce $\mathrm{HAB}$ predictions based on the computational model and present the uncertainties in an understandable manner.

In modern marine science, the observations and computational models are tightly interconnected so that observations work as the initial and boundary condition for the models and forecasts. In the optimal situation they are assimilated in the forecasts and used for validation and verification. In an opposite way, measurement networks and campaigns can be designed with models and it is possible to gain a better understanding of the essential processes when they can be observed at the time they occur and not when the measurements are scheduled. 


\section{References}

Aksnes, D.L., Ulvestad, K.B., Baliño, B.M., Berntsen, J., Egge, J.K., Svendsen, E., 1995. Ecological modelling in coastal waters: towards predictive physicalchemical-biological simulation models. Ophelia 41, 5-36.

Alenius, P., 1993. Finnish Eulerian current measurements, in: Murthy, R., Håkansson, B., Alenius, P. (Eds.), The Gulf of Bothnia Year 1991. Physical transport experiments. Swedish Meteorological and Hydrological Institute, Norrköping. number 15 in SMHI Reports Oceanography. chapter 3, pp. 30-40.

Alenius, P., Nekrasov, A., Myrberg, K., 2003. Variability of the baroclinic Rossby radius in the Gulf of Finland. Continental Shelf Research 23, 563-573.

Andersen, J.H., Carstensen, J., Conley, D.J., Dromph, K., Fleming-Lehtinen, V., Gustafsson, B.G., Josefson, A.B., Norkko, A., Villnäs, A., Murray, C., 2017. Long-term temporal and spatial trends in eutrophication status of the Baltic Sea. Biological Reviews 92, 135-149. URL: https://onlinelibrary.wiley.com/doi/abs/10.1111/brv.12221, doi:10.1111/brv.12221, arXiv:https://onlinelibrary.wiley.com/doi/pdf/10.1111/brv. 12221.

Anderson, J.L., 1996. A method for producing and evaluating probabilistic forecasts from ensemble model integrations. Journal of Climate 9, 1518-1530.

Andersson, A., Meier, H.E.M., Ripszam, M., Rowe, O., Wikner, J., Haglund, P., Eilola, K., Legrand, C., Figueroa, D., Paczkowska, J., Lindehoff, E., Tysklind, M., Elmgren, R., 2015. Projected future climate change and Baltic Sea ecosystem management. AMBIO 44, 345-356. URL: https://doi.org/10.1007/ s13280-015-0654-8, doi:10.1007/s13280-015- 0654- 8 .

Andrejev, O., Myrberg, K., Alenius, P., Lundberg, P.A., 2004. Mean circulation and water exchange in the Gulf of Finland-a study based on three-dimensional modelling. Boreal Environment Research 9, 1-16.

Andrejev, O., Soomere, T., Sokolov, A., Myrberg, K., 2011. The role of the spatial resolution of a three-dimensional hydrodynamic model for marine transport risk assessment. Oceanologia 53, 309 - 334. URL: http://www.sciencedirect.com/ science/article/pii/S0078323411500442, doi:https://doi.org/10.5697/oc.53-1-TI. 309.

Axell, L., Liu, Y., 2016. Application of 3-D ensemble variational data assimilation to a Baltic Sea reanalysis 1989-2013. Tellus A: Dynamic Meteorology and Oceanography 68, 24220. URL: https://doi.org/10.3402/tellusa.v68.24220, doi:10. 3402/tellusa.v68.24220, arXiv: https://doi.org/10.3402/tellusa.v68. 24220. 
BACC II, Author Team (Eds.), 2015. Second assessment of climate change for the Baltic Sea Basin. SpringerOpen. doi:https ://doi.org/10.1007/978-3-319-16006- 1.

Balmaseda, M., Anderson, D., 2009. Impact of initialization strategies and observations on seasonal forecast skill. Geophysical Research Letters 36. URL: https://agupubs.onlinelibrary. wiley.com/doi/abs/10.1029/2008GL035561, doi:10.1029/2008GL035561, arXiv: https://agupubs . onlinelibrary.wiley. com/doi/pdf/10.1029/2008GL035561.

Barceló-Llull, B., Pascual, A., Mason, E., Mulet, S., 2018. Comparing a multivariate global ocean state estimate with high-resolution in situ data: An anticyclonic intrathermocline eddy near the Canary Islands. Frontiers in Marine Science 5, 66. URL: https://www.frontiersin.org/article/10.3389/fmars.2018.00066, doi:10.3389/fmars.2018.00066.

Barker, P.M., Dunn, J.R., Domingues, C.M., Wijffels, S.E., 2011. Pressure sensor drifts in Argo and their impacts. Journal of Atmospheric and Oceanic Technology 28, 1036-1049.

Bell, M.J., Guymer, T.H., Turton, J.D., MacKenzie, B.A., Rogers, R., Hall, S.P., 2013. Setting the course for UK operational oceanography. Journal of Operational Oceanography 6, 1-15. URL: https:// doi.org/10.1080/1755876X.2013.11020146, doi:10.1080/1755876X.2013.11020146, arXiv: https://doi.org/10.1080/1755876X.2013.11020146.

Bianchi, T.S., Engelhaupt, E., Westman, P., Andrén, T., Rolff, C., Elmgren, R., 2000. Cyanobacterial blooms in the Baltic Sea: Natural or human-induced? Limnology and Oceanography 45, 716-726. URL: https://aslopubs.onlinelibrary. wiley.com/doi/abs/10.4319/lo.2000.45.3.0716, doi:10.4319/lo.2000.45.3.0716.

Boss, E., Swift, D., Taylor, L., Brickley, P., Zaneveld, R., Riser, S., Perry, M.J., Strutton, P.G., 2008. Observations of pigment and particle distributions in the western North Atlantic from an autonomous float and ocean color satellite. Limnology and Oceanography 53, 2112-2122. URL: https://aslopubs.onlinelibrary. wiley.com/doi/abs/10.4319/1o.2008.53.5_part_2.2112, doi:10.4319/lo.2008.53.5। _part\_2.2112.

Boyer, T., Antonov, J., Garcia, H., Johnson, D., Locarnini, R., Mishonov, A., Pitcher, M., Baranova, O., Smolyar, I., 2006. World Ocean Database 2005. NOAA Atlas NESDIS 60, U.S Government Printing Office, Washington D.C. Version WOD 2001.

Burchard, H., Bolding, K., Villarreal, M.R., 2004. Three-dimensional modelling of estuarine turbidity maxima in a tidal estuary. Ocean Dynamics 54, 250-265. URL: https://doi.org/10.1007/s10236-003-0073-4, doi:10.1007/s10236- 003- 0073- - .

Burchard, H., Janssen, F., Bolding, K., Umlauf, L., Rennau, H., 2009. Model simulations of dense bottom currents in the Western Baltic Sea. Continental Shelf Research 29, 205 - 220. URL: http://www.sciencedirect.com/science/article/ pii/S0278434307002920, doi:https://doi.org/10.1016/j .csr.2007.09.010. physics of Estuaries and Coastal Seas: Papers from the PECS 2006 Conference.

Choi, M., Chung, H., Yamaguchi, H., Nagakawa, K., 2015. Arctic sea route path planning based on an uncertain ice prediction model. Cold Regions Science and Technology 109, 61 - 69. URL: http://www.sciencedirect.com/science/article/pii/ S0165232X14001748, doi:https://doi.org/10.1016/j . coldregions.2014.10.001. 
Dickey, T.D., 2003. Emerging ocean observations for interdisciplinary data assimilation systems. Journal of Marine Systems 40-41, 5 - 48. URL: http://www.sciencedirect.com/science/article/pii/S0924796303000113, doi:https : //doi.org/10.1016/S0924-7963(03)00011-3. the Use of Data Assimilation in Coupled Hydrodynamic, Ecological and Bio-geo-chemical Models of the Ocean. Selected papers from the 33rd International Liege Colloquium on Ocean Dynamics, held in Liege, Belgium on May 7-11th, 2001.

Dominicis, M.D., Falchetti, S., Trotta, F., Pinardi, N., Giacomelli, L., Napolitano, E., Fazioli, L., Sorgente, R., Haley Jr., P.J., J. Lermusiaux, P.F., Martins, F., Cocco, M., 2014. A relocatable ocean model in support of environmental emergencies. Ocean Dynamics 64, 667-688. URL: https://doi.org/10.1007/ s10236-014-0705-x, doi:10.1007/s10236-014- 0705-x.

Donaldson, R., Dyer, R.M., Kraus, M.J., 1975. Objective evaluator of techniques for predicting severe weather events, in: Bulletin of the American Meteorological Society, AMER METEOROLOGICAL SOC 45 BEACON ST, BOSTON, MA 02108-3693. pp. 755-755.

Ebert, E.E., 2001. Ability of a poor man's ensemble to predict the probability and distribution of precipitation. Monthly Weather Review 129, 2461-2480.

Ehler, C., Douvere, F., 2009. Marine Spatial Planning: a step-by-step approach toward ecosystem-based management. IOC Manuals and Guides 53; ICAM Dossier 6, Unesco, Paris.

Elmgren, R., Blenckner, T., Andersson, A., 2015. Baltic Sea management: Successes and failures. AMBIO 44, 335-344. URL: https://doi.org/10.1007/ s13280-015-0653-9, doi:10.1007/s13280- 015-0653- 9.

European Parliament and Council, 2008. Directive 2008/56/EC of the European Parliament and of the Council of 17 june 2008 establishing a framework for community action in the field of marine environmental policy (Marine Strategy Framework Directive). Http://data.europa.eu/eli/dir/2008/56/oj.

Fennel, W., Seifert, T., Kayser, B., 1991. Rossby radii and phase speeds in the Baltic Sea. Continental Shelf Research 11, 23-36.

Finni, T., Kononen, K., Olsonen, R., Wallström, K., 2001. The history of cyanobacterial blooms in the Baltic Sea. AMBIO: A Journal of the Human Environment $30,172-178$.

Finnish Research Infrastructure Committee, 2013. Finland's strategy and roadmap for research infrastructures 2014-2020. http://www.aka.fi/ globalassets/awanhat/documents/firi/tutkimusinfrastruktuurien_strategia_ ja_tiekartta_2014_en.pdf. Accessed 13.12.2018.

Fleming-Lehtinen, V., Andersen, J.H., Carstensen, J., Łysiak-Pastuszak, E., Murray, C., Pyhälä, M., Laamanen, M., 2015. Recent developments in assessment methodology reveal that the Baltic Sea eutrophication problem is expanding. Ecological Indicators 48, 380 - 388. URL: http://www.sciencedirect.com/science/ article/pii/S1470160X1400377X, doi:https://doi.org/10.1016/j.ecolind.2014.08. 022.

Flemming, N.C., 2002. Strategic planning for operational oceanography, in: Pinardi, N., Woods, J. (Eds.), Ocean forecasting: conceptual basis and applications. Springer Science \& Business Media, Berlin, pp. 1-15. 
Flynn, K.J., McGillicuddy, D.J., 2018. Modeling marine harmful algal blooms: Current status and future prospects, in: Shumway, S.E., Burkholder, J.M., Morton, S.L. (Eds.), Harmful Algal Blooms. Wiley-Blackwell. chapter 3, pp. 115-134. URL: https://onlinelibrary. wiley.com/doi/abs/10.1002/9781118994672.ch3, doi:10.1002/9781118994672.ch3, arXiv: https://onlinelibrary.wiley.com/doi/pdf/10.1002/9781118994672.ch3.

Fonselius, S., Valderrama, J., 2003. One hundred years of hydrographic measurements in the Baltic Sea. Journal of Sea Research 49, 229-241.

Gaillard, F., Autret, E., Thierry, V., Galaup, P., Coatanoan, C., Loubrieu, T., 2009. Quality control of large Argo datasets. Journal of Atmospheric and Oceanic Technology 26, 337-351. URL: https://doi.org/10.1175/2008JTECHO552.1, doi:10.1175/2008JTECH0552.1, arXiv: https://doi.org/10.1175/2008JTECH0552.1.

Gill, A.E., 1982. Atmosphere-Ocean Dynamics. volume 30 of International Geophysics. Academic Press, San Diego, USA.

Golbeck, I., Li, X., Janssen, F., Brüning, T., Nielsen, J.W., Huess, V., Söderkvist, J., Büchmann, B., Siiriä, S.M., Vähä-Piikkiö, O., Hackett, B., Kristense, N.M., Engedahl, H., Blockley, E., Sellar, A., Lagemaa, P., Ozer, J., Legrand, S., Ljungemyr, P., Axell, L., 2015. Uncertainty estimation for operational ocean forecast products - a multi-model ensemble for the North Sea and the Baltic Sea. Ocean Dynamics 65, 1603-1631.

Gould, J., Roemmich, D., Wijffels, S., Freeland, H., Ignaszewsky, M., Jianping, X., Pouliquen, S., Desaubies, Y., Send, U., Radhakrishnan, K., Takeuchi, K., Kim, K., Danchenkov, M., Sutton, P., King, B., Owens, B., Riser, S., 2004. Argo profiling floats bring new era of in situ ocean observations. Eos, Transactions American Geophysical Union 85, 185-191. URL: https://agupubs.onlinelibrary. wiley.com/doi/abs/10.1029/2004EO190002, doi:10.1029/2004E0190002, arXiv: https: //agupubs .onlinelibrary.wiley.com/doi/pdf/10. 1029/2004E0190002.

Grayek, S., Stanev, E.V., Schulz-Stellenfleth, J., 2015. Assessment of the Black Sea observing system. A focus on 2005-2012 Argo campaigns. Ocean Dynamics 65, 1665-1684. URL: https://doi.org/10.1007/s10236-015-0889-8, doi:10.1007/ s10236- 015 - 0889 - 8 .

Groetsch, P.M.M., Simis, S.G.H., Eleveld, M.A., Peters, S.W.M., 2016. Spring blooms in the Baltic Sea have weakened but lengthened from 2000 to 2014 . Biogeosciences 13, 4959-4973. URL: https:/www.biogeosciences.net/13/4959/ 2016/, doi:10.5194/bg - 13-4959- 2016.

Guinehut, S., Dhomps, A.L., Larnicol, G., Le Traon, P.Y., 2012. High resolution 3D temperature and salinity fields derived from in situ and satellite observations. Ocean Science 8, 845-857. URL: https://www.ocean-sci.net/8/845/2012/, doi:10. 5194/os - 8- 845- 2012.

Haapala, J., 1994. Upwelling and its influence on nutrient concentration in the coastal area of the Hanko Peninsula, entrance of the Gulf of Finland. Estuarine, Coastal and Shelf Science 38, 507-521.

Haapala, J., Alenius, P., 1994. Temperature and salinity statistics for the northern Baltic Sea 1961-1990. Finnish Marine Research , 51-121. 
Håkansson, B., Alenius, P., Brydsten, L., 1996. Physical environment in the Gulf of Bothnia. Ambio , 5-12.

Hamill, T.M., 2001. Interpretation of rank histograms for verifying ensemble forecasts. Monthly Weather Review 129, 550-560.

Hamill, T.M., Colucci, S.J., 1997. Verification of Eta-RSM shortrange ensemble forecasts. Monthly Weather Review 125, 13121327. URL: https://doi.org/10.1175/1520-0493(1997)125<1312: VOERSR>2.0.CO;2, doi:10.1175/1520-0493 (1997) 125<1312:VOERSR>2 . 0. C 0 ; 2, arXiv: https : //doi. org/10.1175/1520-0493 (1997) 125<1312: VOERSR>2 . . .C0;2.

Heisler, J., Glibert, P., Burkholder, J., Anderson, D., Cochlan, W., Dennison, W., Dortch, Q., Gobler, C., Heil, C., Humphries, E., Lewitus, A., Magnien, R., Marshall, H., Sellner, K., Stockwell, D., Stoecker, D., Suddleson, M., 2008. Eutrophication and harmful algal blooms: A scientific consensus. Harmful Algae 8, 3 13. URL: http://www.sciencedirect.com/science/article/pii/S1568988308001066, doi:https://doi.org/10.1016/j. hal.2008.08.006. hABs and Eutrophication.

Hela, I., 1958. A hydrographical survey of the waters in the Åland Sea. Geophysica $6,219-242$.

HELCOM, 2017. Manual for marine monitoring in the COMBINE programme of HELCOM. Part C, Programme for monitoring of eutrophication and its effects, Annex C-2, Technical Annex I, HELCOM .

HELCOM, 2018a. Helcom maritime assessment 2018, Helsinki Comission (HELCOM) - Baltic Marine Environment Protection Commission.

HELCOM, 2018b. State of the Baltic Sea - second HELCOM holistic assessment 2011-2016, Helsinki Comission (HELCOM) - Baltic Marine Environment Protection Commission.

Hersbach, H., 2000. Decomposition of the continuous ranked probability score for ensemble prediction system. Weather and Forecasting 15, 559-570.

Hintze, J.L., Nelson, R.D., 1998. Violin plots: A box plot-density trace synergism. The American Statistician 52, 181-184.

HIRLAM-B, 2015. System documentation. Technical Report. HIRLAM consortium. URL: http://www.hirlam.org/.

Hobday, A.J., Spillman, C.M., Paige Eveson, J., Hartog, J.R., 2016. Seasonal forecasting for decision support in marine fisheries and aquaculture. Fisheries Oceanography 25, 45-56. URL: https: //onlinelibrary.wiley.com/doi/abs/10.1111/fog.12083, doi:10.1111/fog.12083, arXiv: https://onlinelibrary.wiley.com/doi/pdf/10.1111/fog. 12083.

Holtermann, P.L., Burchard, H., Gräwe, U., Klingbeil, K., Umlauf, L., 2014. Deep-water dynamics and boundary mixing in a nontidal stratified basin: A modeling study of the Baltic Sea. Journal of Geophysical Research: Oceans 119, 1465-1487. URL: https://agupubs.onlinelibrary. wiley.com/doi/abs/10.1002/2013JC009483, doi:10.1002/2013Jc009483, arXiv: https://agupubs. onlinelibrary.wiley.com/doi/pdf/10.1002/2013JC009483. 
Hordoir, R., Axell, L., Höglund, A., Dieterich, C., Fransner, F., Gröger, M., Liu, Y., Pemberton, P., Schimanke, S., Andersson, H., Ljungemyr, P., Nygren, P., Falahat, S., Nord, A., Jönsson, A., Lake, I., Döös, K., Hieronymus, M., Dietze, H., Löptien, U., Kuznetsov, I., Westerlund, A., Tuomi, L., Haapala, J., 2018. NemoNordic: A NEMO based ocean model for Baltic \& North Seas, research and operational applications. Geoscientific Model Development Discussions 2018, 1-29. URL: https://www.geosci-model-dev-discuss.net/gmd-2018-2/, doi:10.5194/ gmd-2018- 2 .

Hordoir, R., Axell, L., Löptien, U., Dietze, H., Kuznetsov, I., 2015. Influence of sea level rise on the dynamics of salt inflows in the Baltic Sea. Journal of Geophysical Research: Oceans 120, 6653-6668. URL: https://agupubs.onlinelibrary. wiley.com/doi/abs/10.1002/2014JC010642, doi:10.1002/2014Jc010642, arXiv: https://agupubs . onlinelibrary.wiley.com/doi/pdf/10.1002/2014JC010642.

Hordoir, R., Dieterich, C., Basu, C., Dietze, H., Meier, H., 2013. Freshwater outflow of the Baltic Sea and transport in the Norwegian current: A statistical correlation analysis based on a numerical experiment. Continental Shelf Research 64, 1-9. doi:http://dx.doi.org/10.1016/j.csr.2013.05.006.

Howes, E., Joos, F., Eakin, M., Gattuso, J.P., 2015. An updated synthesis of the observed and projected impacts of climate change on the chemical, physical and biological processes in the oceans. Frontiers in Marine Science 2, 36. URL: https://www.frontiersin.org/article/10.3389/fmars.2015.00036, doi:10.3389/fmars. 2015.00036.

IOC, SCOR, IAPSO, 2010. The international thermodynamic equation of seawater - 2010: Calculation and use of thermodynamic properties. Number 56 in Intergovernmental Oceanographic Commission, Manuals and Guides, UNESCO.

Jaanus, A., Andersson, A., Olenina, I., Toming, K., Kaljurand, K., 2011. Changes in phytoplankton communities along a north-south gradient in the Baltic Sea between 1990 and 2008. Boreal Environment Research 16 (suppl. A), 191-208.

Johansson, M., Boman, H., Kahma, K.K., Launiainen, J., 2001. Trends in sea level variability in the Baltic Sea. Boreal Environment Research 6, 159-180.

Johansson, M.M., Pellikka, H., Kahma, K.K., Ruosteenoja, K., 2014. Global sea level rise scenarios adapted to the Finnish coast. Journal of Marine Systems 129, 35 - 46. URL: http://www.sciencedirect.com/science/article/pii/ S0924796312001686, doi:https://doi.org/10.1016/j .jmarsys.2012.08.007.

Johnson, K.S., Berelson, W.M., Boss, E.S., Chase, Z., Claustre, H., Emerson, S.R., Gruber, N., Körtzinger, A., Perry, M.J., Riser, S.C., 2009. Observing biogeochemical cycles at global scales with profiling floats and gliders: prospects for a global array. Oceanography 22, 216-225.

Jolliffe, I.T., Stephenson, D.B., 2003. Forecast Verification - A Practitioner's guide in Atmospheric Science. John Wiley and sons, The Atrium, Chichester, West Sussex PO19 8SQ, England.

Kahma, K., Pettersson, H., Tuomi, L., 2003. Scatter diagram wave statistics from the northern Baltic Sea. MERI-Report Series of the Finnish Institute of Marine Research 49, 15-32. 
Kahru, M., Håkansson, B., Rud, O., 1995. Distributions of the sea-surface temperature fronts in the Baltic Sea as derived from satellite imagery. Continental Shelf Research 15, 663 - 679. URL: http://www.sciencedirect.com/science/article/ pii/0278434394E0030P, doi:http://dx.doi.org/10. 1016/0278-4343(94) E0030 - P.

Kamenkovich, I., Cheng, W., Schmid, C., Harrison, D.E., 2011. Effects of eddies on an ocean observing system with profiling floats: Idealized simulations of the Argo array. Journal of Geophysical Research: Oceans $116 . \quad$ URL: https://agupubs.onlinelibrary. wiley.com/doi/abs/10.1029/2010JC006910, doi:10.1029/2010Jc006910, arXiv: https://agupubs . onlinelibrary.wiley. com/doi/pdf/10.1029/2010Jc006910.

Karlson, B., Eilola, K., Hansson, M., 2008. Cyanobacterial blooms in the Baltic Sea: correlating bloom observations with environmental conditions, in: Proc 13th Int Conf on Harmful Algae, pp. 247-252.

Karpechko, A.Y., Peterson, K.A., Scaife, A.A., Vainio, J., Gregow, H., 2015. Skilful seasonal predictions of Baltic Sea ice cover. Environmental Research Letters 10, 044007. URL: http://stacks.iop.org/1748-9326/10/i=4/a=044007.

Kiiltomäki, A., 2008. Development of the Baltic Sea indicator report by Alg@line measurements and BalEco model results. Master's thesis. University of Helsinki.

Kikas, V., Lips, U., 2016. Upwelling characteristics in the Gulf of Finland (Baltic Sea) as revealed by Ferrybox measurements in 2007-2013. Ocean Science 12, 843-859. URL: https://www.ocean-sci.net/12/843/2016/, doi:10.5194/ os - $12-843-2016$.

Klatt, O., Boebel, O., Fahrbach, E., 2007. A profiling float's sense of ice. Journal of Atmospheric and Oceanic Technology 24, 13011308. URL: https://doi.org/10.1175/JTECH2026.1, doi:10.1175/JTECH2026.1, arXiv: https://doi.org/10.1175/JTECH2026.1.

Korpinen, S., Laamanen, M., Heiskanen, A.S., Ahola, M., Alenius, P., Attila, J., et al. (Eds.), 2015. Suomen Merenhoidon Seurantakäsikirja. Ministry of the Environment, 160 (in Finnish). Http://www.ymparisto.fi/download/noname/\%7BECF9A983-AC50-4DABB237-D7EA3A09664B\%7D/103978.

Korpinen, S., Laamanen, M., Suomela, J., Paavilainen, P., Lahtinen, T., Ekebom, J. (Eds.), 2018. Suomen meriympäristön tila 2018, Suomen ympäristökeskus SYKE. Grano, Helsinki. ISBN 978-952-11-4968-9 (PDF).

Körtzinger, A., Schimanski, J., Send, U., Wallace, D., 2004. The ocean takes a deep breath. Science 306, 1337-1337. URL: http: //science.sciencemag.org/content/306/5700/1337, doi:10.1126/science.1102557, arXiv: http://science. sciencemag. org/content/306/5700/1337. full. pdf.

Kowalewski, M., Ostrowski, M., 2005. Coastal up-and downwelling in the southern Baltic. Oceanologia 47, 453-475.

Krapivin, V.F., Varotsos, C.A., 2016. Modelling the $\mathrm{CO}_{2}$ atmosphere-ocean flux in the upwelling zones using radiative transfer tools. Journal of Atmospheric and Solar-Terrestrial Physics 150-151, 47 - 54. URL: http://www.sciencedirect. com/science/article/pii/S1364682616302425, doi:https ://doi . org/10.1016/j . jastp. 2016.10.015. 
Krauss, W., Brügge, B., 1990. Wind-produced water exchange between the deep basins of the Baltic Sea. Journal of Physical Oceanography 21, 373-384.

Kuosa, H., Fleming-Lehtinen, V., Lehtinen, S., Lehtiniemi, M., Nygård, H., Raateoja, M., Raitaniemi, J., Tuimala, J., Uusitalo, L., Suikkanen, S., 2017. A retrospective view of the development of the Gulf of Bothnia ecosystem. Journal of Marine Systems 167, 78 - 92. URL: http://www. sciencedirect.com/science/article/pii/S0924796316304006, doi:https://doi.org/ 10.1016/j . jmarsys. 2016.11.020.

Kutser, T., 2006. Monitoring cyanobacterial blooms by satellite remote sensing. Estuarine, Coastal and Shelf Science 67, 303-312.

Laamanen, M. (Ed.), 2016. Suomen Merenhoitosuunnitelman Toimenpideohjelma 2016 - 2021 (Programme of Measures for the Development and Implementation of the Marine Strategy in Finland 2016 - 2021), Reports of the Ministry of the Environment 5/2016, Helsinki.

Lagemaa, P., 2012. Operational forecasting in Estonian marine waters. Ph.D. thesis. TALLINN UNIVERSITY OF TECHNOLOGY.

Large, W.G., Yeager, S.G., 2004. Diurnal to decadal global forcing for ocean and sea-ice models: the data sets and flux climatologies. NCAR Technical Note, NCAR/TN-460+STR, CGD Division of the National Center for Atmospheric Research. URL: http://dx.doi.org/10.5065/D6KK98Q6.

Le Traon, P.Y., 2013. From satellite altimetry to Argo and operational oceanography: three revolutions in oceanography. Ocean Science , 901-915.

Lehmann, A., Krauß, W., Hinrichsen, H.H., 2001. Effects of remote and local atmospheric forcing on circulation and upwelling in the Baltic Sea. Tellus A: Dynamic Meteorology and Oceanography 54, 299-316.

Lehmann, A., Myrberg, K., 2008. Upwelling in the Baltic Sea - a review. Journal of Marine Systems 74, S3 - S12. URL: http://www.sciencedirect.com/ science/article/pii/S0924796308002492, doi:https://doi.org/10.1016/j.jmarsys. 2008. 02 . 010. baltic Sea Science Congress 2007.

Lehmann, A., Myrberg, K., Höflich, K., 2012. A statistical approach to coastal upwelling in the baltic sea based on the analysis of satellite data for 1990-2009. Oceanologia 54, 369-393.

Lehtoranta, J., Savchuk, O.P., Elken, J., Dahlbo, K., Kuosa, H., Raateoja, M., Kauppila, P., Räike, A., Pitkänen, H., 2017. Atmospheric forcing controlling inter-annual nutrient dynamics in the open Gulf of Finland. Journal of Marine Systems 171, 4 - 20. URL: http://www.sciencedirect.com/science/article/pii/ S0924796317300659, doi:https://doi.org/10.1016/j . jmarsys.2017.02.001. towards a healthier Gulf of Finland - " results of the International Gulf of Finland Year 2014.

Lentz, W., 1971. Monatskarte der Temperatur der Ostsee dargestellt für verschiedene Tiefenhorisonte [Monthly maps of the temperature of the Baltic Sea for different depths]. Deutsche Hydrographische Zeitschrift, Ergänzungshäft Reihe B , 1-148.

Leppäranta, M., Myrberg, K., 2009. Physical Oceanography of the Baltic Sea. 1 ed., Praxis Publishing Ltd, Chichester, UK. 
Leutbecher, M., 2018. Ensemble size: How suboptimal is less than infinity? Quarterly Journal of the Royal Meteorological Society URL: https://rmets.onlinelibrary.wiley.com/doi/abs/10.1002/qj.3387, doi:10.1002/qj . 3387, arXiv: https://rmets.onlinelibrary.wiley.com/doi/pdf/10.1002/qj .3387.

Leutbecher, M., Palmer, T., 2008. Ensemble forecasting. Journal of Computational Physics 227, 3515-3539.

Lévy, M., Ferrari, R., Franks, P.J.S., Martin, A.P., Riviére, P., 2012. Bringing physics to life at the submesoscale. Geophysical Research Letters 39. URL: https://agupubs.onlinelibrary. wiley.com/doi/abs/10.1029/2012GL052756, doi:10.1029/2012GL052756, arXiv: https://agupubs. onlinelibrary.wiley.com/doi/pdf/10.1029/2012GL052756.

Liblik, T., Karstensen, J., Testor, P., Alenius, P., Hayes, D., Ruiz, S., Heywood, K., Pouliquen, S., Mortier, L., Mauri, E., 2016. Potential for an underwater glider component as part of the Global Ocean Observing System. Methods in Oceanography 17, 50 - 82. URL: http://www.sciencedirect.com/science/article/ pii/S2211122016300056, doi:https://doi.org/10.1016/j .mio.2016.05.001. special section on Novel instrumentation in Oceanography: a dedication to Rob Pinkel.

Lindow, H., 1997. Experimentelle Simulationen windangeregter dynamischer Muster in hochauflösenden numerischen Modellen. Institut für Ostseeforschung Warnemünde.

Lips, I., Lips, U., 2008. Abiotic factors influencing cyanobacterial bloom development in the Gulf of Finland (Baltic Sea). Hydrobiologia 614, 133-140. URL: https://doi.org/10.1007/s10750-008-9449-2, doi:10.1007/s10750- 008- 9449- 2.

Lips, I., Lips, U., Liblik, T., 2009. Consequences of coastal upwelling events on physical and chemical patterns in the central Gulf of Finland (Baltic Sea). Continental Shelf Research 29, 1836 - 1847. URL: http://www.sciencedirect. com/science/article/pii/S0278434309002064, doi:https ://doi.org/10.1016/j .csr. 2009.06.010.

Lips, U., Kikas, V., Liblik, T., Lips, I., 2016. Multi-sensor in situ observations to resolve the sub-mesoscale features in the stratified Gulf of Finland, Baltic Sea. Ocean Science 12, 715-732. URL: https://www.ocean-sci.net/12/715/2016/, doi:10.5194/os-12-715-2016.

Lisitzin, E., 1974. Sea-level changes. volume 8. Elsevier Scientific Publishing Company, Amsterdam.

Liu, Y., Weisberg, R.H., Hu, C., Zheng, L., 2011. Tracking the Deepwater Horizon oil spill: A modeling perspective. Eos, Transactions American Geophysical Union 92, 45-46. URL: https://agupubs.onlinelibrary. wiley.com/doi/abs/10.1029/2011EO060001, doi:10.1029/2011E0060001, arXiv: https://agupubs. onlinelibrary.wiley.com/doi/pdf/10.1029/2011E0060001.

Lorenz, E.N., 1965. A study of the predictability of a 28-variable atmospheric model. Tellus 17, 321-333. URL: https://onlinelibrary.wiley.com/doi/abs/ 10.1111/j.2153-3490.1965.tb01424.x, doi:10.1111/j.2153-3490.1965.tb01424.x, arXiv:https://onlinelibrary.wiley.com/doi/pdf/10.1111/j.2153-3490.1965. tb01424.x.

Luyten, P., Jones, J., Proctor, R., Tabor, A., Tett, P., Wild-Allen, K., 1999. COHERENS - A coupled hydrodynamical-ecological model for regional and shelf 
seas: User Documentation. Management Unit of the Mathematical Models of the north Sea, Belgium.

Madec, G., the NEMO team, 2008. NEMO ocean engine. Institut PierreSimon Laplace (IPSL). France. URL: https://www.nemo-ocean.eu/bibliography/ documentation/. note du Pôle de modélisation, No 27.

Marmefelt, E., Omstedt, A., 1993. Deep water properties in the Gulf of Bothnia. Continental Shelf Research , 169-187.

Marshall, J., Adcroft, A., Hill, C., Perelman, L., Heisey, C., 1997a. A finitevolume incompressible Navier Stokes model for studies of the ocean on parallel computers. Journal of Geophysical Research 102, 5753-5766.

Marshall, J., Hill, C., Perelman, L., Adcroft, A., 1997b. Hydrostatic, quasihydrostatic, and non-hydrostatic ocean modeling. Journal of Geophysical Research 102, 5733-5752.

Marzban, C., Wang, R., Kong, F., Leyton, S., 2011. On the effect of correlations on rank histograms: Reliability of temperature and wind speed forecasts from finescale ensemble reforecasts. Monthly Weather Review 139, 295-310.

Mazur-Marzec, H., 2006. Toxic Nodularia spumigena blooms in the coastal waters of the Gulf of Gdansk: a ten-year survey. OCEANOLOGIA 48, 255-273.

McGillicuddy, D.J., 2016. Mechanisms of physical-biologicalbiogeochemical interaction at the oceanic mesoscale. Annual Review of Marine Science 8, 125-159. URL: https://doi.org/10.1146/ annurev-marine-010814-015606, doi:10.1146/annurev-marine-010814-015606, arXiv: https://doi .org/10.1146/annurev-marine-010814-015606. pMID: 26359818.

Meier, H.E.M., 2001. On the parameterization of mixing in threedimensional Baltic Sea models. Journal of Geophysical Research: Oceans 106, 30997-31016. URL: https://agupubs.onlinelibrary. wiley.com/doi/abs/10.1029/2000JC000631, doi:10.1029/2000Jc000631, arXiv: https://agupubs. onlinelibrary.wiley. com/doi/pdf/10.1029/2000Jc000631.

Meier, H.E.M., Andersson, H.C., Arheimer, B., Donnelly, C., Eilola, K., Gustafsson, B.G., Kotwicki, L., Neset, T.S., Niiranen, S., Piwowarczyk, J., Savchuk, O.P., Schenk, F., Wessławski, J.M., Zorita, E., 2014. Ensemble modeling of the Baltic Sea ecosystem to provide scenarios for management. AMBIO 43, 37-48. URL: https://doi.org/10.1007/s13280-013-0475-6, doi:10.1007/s13280- 013- 0475- 6 .

Meier, H.E.M., Feistel, R., Piechura, J., Arneborg, L., Burchard, H., Fiekas, V., Golenko, N., Kuzmina, N., Mohrholz, V., Nohr, C., et al., 2006. Ventilation of the Baltic Sea deep water: A brief review of present knowledge from observations and models. Oceanologia 48.

Melzner, F., Thomsen, J., Koeve, W., Oschlies, A., Gutowska, M.A., Bange, H.W., Hansen, H.P., Körtzinger, A., 2013. Future ocean acidification will be amplified by hypoxia in coastal habitats. Marine Biology 160, 1875-1888.

Metropolis, N., Ulam, S., 1949. The Monte Carlo Method. Journal of the American Statistical Association 44, 335-341. URL: https://www.tandfonline.com/ doi/abs/10.1080/01621459.1949.10483310, doi:10.1080/01621459.1949.10483310, arXiv: https://www. tandfonline.com/doi/pdf/10. 1080/01621459. 1949. 10483310. pMID: 18139350. 
Mohammadi-Aragh, M., Goessling, H., Losch, M., Hutter, N., Jung, T., 2018. Predictability of Arctic sea ice on weather time scales. Scientific reports 8, 1-7. URL: http://www.nature.com/articles/s41598-018-24660-0, doi:10.1038/ s41598- $018-24660-0$.

Mohrholz, V., 2018. Major Baltic inflow statistics - revised. Frontiers in Marine Science 5, 384. URL: https://www.frontiersin.org/article/10.3389/fmars.2018. 00384, doi:10.3389/fmars.2018.00384.

Mohrholz, V., Naumann, M., Nausch, G., Krüger, S., Gräwe, U., 2015. Fresh oxygen for the Baltic Sea - an exceptional saline inflow after a decade of stagnation. Journal of Marine Systems 148, 152 - 166. URL: http://www. sciencedirect.com/science/article/pii/S0924796315000457, doi:https://doi.org/ $10.1016 / j$. jmarsys. 2015.03.005.

Molteni, F., Buizza, R., Palmer, T., Petroliagis, T., 1996. The ECMWF ensemble prediction system: Methodology and validation. Quarterly Journal of the Royal Meteorological Society 122, 73-119.

Mylne, K.R., Evans, R.E., Clark, R.T., 2002. Multi-model multi-analysis ensembles in quasi-operational medium-range forecasting. Quarterly Journal of the Royal Meteorological Society 128, 361-384.

Myrberg, K., Andrejev, O., 2003. Main upwelling regions in the Baltic Sea - a statistical analysis based on three-dimensional modelling. Boreal Environmental Research 8, 97-112.

Mälkki, P., 2001. Oceanography in Finland 1918-2000. Geophysica 37, 225-259.

Niemi, A., 1979. Blue-green algal blooms and N:P ratio in the Baltic Sea. Acta Botanica Fennica 110, 57-61.

Ninove, F., Traon, P.Y.L., Remy, E., Guinehut, S., 2016. Spatial scales of temperature and salinity variability estimated from Argo observations. Ocean Science $12,1-7$.

Nissling, A., Johansson, U., Jacobsson, M., 2006. Effects of salinity and temperature conditions on the reproductive success of turbot (Scophthalmus maximus) in the Baltic Sea. Fisheries Research 80, 230 - 238. URL: http://www.sciencedirect.com/science/article/pii/S0165783606001469, doi:https: //doi.org/10.1016/j. fishres.2006.04.005.

Norman, M., Parampil, S.R., Rutgersson, A., Sahlée, E., $2013 . \quad$ Influence of coastal upwelling on the air-sea gas exchange of $\mathrm{CO}_{2}$ in a Baltic Sea basin. Tellus B: Chemical and Physical Meteorology 65, 21831. URL: https://doi.org/10.3402/tellusb.v65i0.21831, doi:10.3402/tellusb. v65i0.21831, arXiv:https://doi.org/10.3402/tellusb.v65i0.21831.

Nowicki, A., Janecki, M., Dzierzbicka-Głowacka, L., 2019. Operational system for automatic coastal upwelling detection in the Baltic Sea based on the 3D CEMBS model. Journal of Operational Oceanography , 112URL: https://doi.org/10.1080/1755876X.2019.1569748, doi:10.1080/1755876X. 2019. 1569748, arXiv: https://doi.org/10.1080/1755876X.2019. 1569748.

Palmén, E., 1930. Untersuchungen über die Strömungen in den Finnland umgebenden Meeren. Soc. Scient. Fenn., Comm. Phys.-Math. V. In German. 
Pellikka, H., Leijala, U., Johansson, M.M., Leinonen, K., Kahma, K.K., 2018. Future probabilities of coastal floods in Finland. Continental Shelf Research 157, 32 - 42. URL: http://www.sciencedirect.com/science/article/pii/ S0278434316302060, doi:https ://doi.org/10.1016/j.csr.2018.02.006.

Pinardi, N., Woods, J. (Eds.), 2002. Ocean forecasting: conceptual basis and applications. Springer Science \& Business Media, Berlin.

Placke, M., Meier, H.E.M., Gräwe, U., Neumann, T., Frauen, C., Liu, Y., 2018. Long-term mean circulation of the Baltic Sea as represented by various ocean circulation models. Frontiers in Marine Science 5, 287. URL: https://www. frontiersin.org/article/10.3389/fmars.2018.00287, doi:10.3389/fmars.2018.00287.

Raateoja, M., 2013. Deep-water oxygen conditions in the Bothnian Sea. Boreal Environment Research 18, 235-250.

Raateoja, M., Kuosa, H., Hällfors, S., 2011. Fate of excess phosphorus in the Baltic Sea: A real driving force for cyanobacterial blooms? Journal of Sea Research 65, 315 - 321. URL: http://www.sciencedirect.com/science/article/pii/ S1385110111000050, doi:https://doi.org/10.1016/j . seares.2011.01.004.

Riser, S.C., Freeland, H.J., Roemmich, D., Wijffels, S., Troisi, A., Belbéoch, M., Gilbert, D., Xu, J., Pouliquen, S., Thresher, A., Le Traon, P.Y., Maze, G., Klein, B., Ravichandran, M., Grant, F., Poulain, P.M., Suga, T., Lim, B., Sterl, A., Sutton, P., Mork, K.A., Vélez-Belchí, P.J., Ansorge, I., King, B., Turton, J., Baringer, M., Jayne, S.R., 2016. Fifteen years of ocean observations with the global Argo array. Nature Climate Change 6, 145.

Roemmich, D., Boebel, O., Desaubies, Y., Freeland, H., Kim, K., King, B., Le Traon, P.Y., Molinari, R., Owens, B.W., Riser, S., Send, U., Takeuchi, K., Wijffels, S., 2001. Observing the Oceans in the 21st Century. chapter Argo: The Global Array of Profiling Floats. URL: https://archimer.ifremer.fr/doc/00090/20097/.

Roemmich, D., Church, J., Gilson, J., Monselesan, D., Sutton, P., Wijffels, S., 2015. Unabated planetary warming and its ocean structure since 2006. Nature climate change 5,240 .

Rolff, C., Elfwing, T., 2015. Increasing nitrogen limitation in the Bothnian Sea, potentially caused by inflow of phosphate-rich water from the Baltic Proper. Ambio 44, 601-611.

Rönnberg, C., Bonsdorff, E., 2004. Baltic sea eutrophication: area-specific ecological consequences. Hydrobiologia 514, 227-241. URL: https://doi.org/10.1023/B: HYDR.0000019238.84989.7f, doi:10.1023/B:HYDR.0000019238.84989.7f.

Ruhl, H.A., André, M., Beranzoli, L., Çağatay, M.N., Colaço, A., Cannat, M., Dañobeitia, J.J., Favali, P., Géli, L., Gillooly, M., Greinert, J., Hall, P.O., Huber, R., Karstensen, J., Lampitt, R.S., Larkin, K.E., Lykousis, V., Mienert, J., Miranda, J.M., Person, R., Priede, I.G., Puillat, I., Thomsen, L., Waldmann, C., 2011. Societal need for improved understanding of climate change, anthropogenic impacts, and geo-hazard warning drive development of ocean observatories in European seas. Progress in Oceanography 91, 1-33. URL: http://www.sciencedirect.com/science/article/pii/S0079661111000383, doi:https: //doi.org/10.1016/j. pocean.2011.05.001. 
Ruokanen, L., Kaitala, S., Fleming, V., Maunula, P., 2003. Alg@line-joint operational unattended phytoplankton monitoring in the Baltic Sea, in: H. Dahlin, N.C. Flemming, K.N., Petersson, S. (Eds.), Building the European Capacity in Operational Oceanography, Proceedings of the Third International Conference on EuroGOOS. Elsevier. volume 69 of Elsevier Oceanography Series, pp. 519 522 .

Räsänen, T., Laakkonen, S., 2007. Cold war and the environment: The role of Finland in international environmental politics in the Baltic Sea region. Ambio $36,229-36$.

Sandén, P., Danielsson, Å., 1995. Spatial properties of nutrient concentrations in the Baltic Sea. Environmental Monitoring and Assessment 34, 289-307. URL: https://doi.org/10.1007/BF00554799, doi:10.1007/BF00554799.

Särkkä, J., Kahma, K.K., Kämäräinen, M., Johansson, M.M., Saku, S., 2017. Simulated extreme sea levels at Helsinki. Boreal Environment Research 22, 299-315.

Schiller, A., Brassington, G.B., 2011. Operational oceanography in the 21st century. Springer Science \& Business Media.

Schroeder, K., Chiggiato, J., Josey, S., Borghini, M., Aracri, S., Sparnocchia, S., 2017. Rapid response to climate change in a marginal sea. Scientific reports 7 , 4065 .

von Schuckmann, K., Palmer, M., Trenberth, K., Cazenave, A., Chambers, D., Champollion, N., Hansen, J., Josey, S., Loeb, N., Mathieu, P.P., Meyssignac, B., Wild, M., 2016. An imperative to monitor Earth's energy imbalance. Nature Climate Change 6, 138.

Seifert, T., Kayser, B., 1995. A high resolution spherical grid topography of the Baltic Sea. Meereswissenschaftliche Berichte 9, 72-88.

She, J., Allen, I., Buch, E., Crise, A., Johannessen, J.A., Le Traon, P.Y., Lips, U., Nolan, G., Pinardi, N., Reißmann, J.H., Siddorn, J., Stanev, E., Wehde, H., 2016. Developing European operational oceanography for Blue Growth, climate change adaptation and mitigation, and ecosystem-based management. Ocean Science 12, 953-976. URL: https://www.ocean-sci.net/12/953/2016/, doi:10.5194/ os - 12- 953 - 2016.

Siedlecki, S.A., Kaplan, I.C., Hermann, A.J., Nguyen, T.T., Bond, N.A., Newton, J.A., Williams, G.D., Peterson, W.T., Alin, S.R., Feely, R.A., 2016. Experiments with seasonal forecasts of ocean conditions for the northern region of the California Current upwelling system. Scientific Reports 6, 27203.

Sitarz, D., 1993. Agenda 21: The earth summit strategy to save our planet .

Sproson, D., Sahlée, E., 2014. Modelling the impact of Baltic Sea upwelling on the atmospheric boundary layer. Tellus A: Dynamic Meteorology and Oceanography 66, 24041. URL: https://doi.org/10.3402/tellusa.v66.24041, doi:10.3402/tellusa. v66.24041, arXiv:https://doi.org/10.3402/tellusa.v66.24041.

Stigebrandt, A., 2001. Physical oceanography of the Baltic Sea, in: Wulff, F.V., Rahm, L.A., Larsson, P. (Eds.), A systems analysis of the Baltic Sea. SpringerVerlag, Berlin Heidelberg. volume 148. chapter 2, pp. 19-74. 
Stipa, T., Skogen, M., Sehested Hansen, I., Eriksen, A., Hense, I., Kiiltomäki, A., Søiland, H., Westerlund, A., 2003. Short-term effects of nutrient reductions in the North Sea and the Baltic Sea as seen by an ensemble of numerical models. Meri - Report Series of the Finnish Institute of Marine Research 49, 43-70.

Stommel, H., 1963. Varieties of oceanographic experience. Science 139, 572-576.

SYKE, 2015. Marcoast service for water and sea surface temperatures (SST). accessed 15 january 2015. http://www.environment.fi/seasurfacetemperature. NOAA AVHRR satellite data, processing by SYKE in the GMES Downstream framework in ESA MarCoast 2 project.

SYKE, 2018a. The risk of significant blue-green algae blooms in summer 2018 is lower than earlier years in Finnish marine areas. URL: http://www.syke. fi/en-US/Current/The_risk_of_significant_bluegreen_algae_(47031). press Release 2018-06-07. Downloaded 2018-10-12.

SYKE, 2018b. Summary of algal bloom monitoring 2018: Sweltering summer brought exceptional cyanobacterial surface blooms to sea areas, in lakes abundant cyanobacterial blooms took place earlier. URL: http://www.syke.fi/en-US/Current/Algal_reviews/Summary_reviews/ Summary_of_algal_bloom_monitoring_2018_S(47752). summary Review 201808-30. Downloaded 2018-10-12.

Talagrand, O., 1999. Evaluation of probabilistic prediction systems, in: Workshop proceedings" Workshop on predictability", 20-22 October 1997, ECMWF, Reading, UK.

Tedesco, L., Piroddi, C., Kämäri, M., Lynam, C., 2016. Capabilities of Baltic Sea models to assess environmental status for marine biodiversity. Marine Policy 70, 1 - 12. URL: http://www.sciencedirect.com/science/article/pii/ S0308597X16301932, doi:https://doi.org/10.1016/j .marpol.2016.04.021.

Thompson, A.F., Chao, Y., Chien, S., Kinsey, J., Flexas, M.M., Erickson, Z.K., Farrara, J., Fratantoni, D., Branch, A., Chu, S., Troesch, M., Claus, B., Kepper, J., 2017. Satellites to seafloor: Toward fully autonomous ocean sampling. Oceanography 30, 160-168.

Thomson, R.E., Emery, W.J., 2014. Data analysis methods in physical oceanography. 3 ed., Elsevier, 225, Wyman Street, Waltham, MA 02451, USA.

Tonani, M., Balmaseda, M., Bertino, L., Blockley, E., Brassington, G., Davidson, F., Drillet, Y., Hogan, P., Kuragano, T., Lee, T., Mehra, A., Paranathara, F., Tanajura, C.A., Wang, H., 2015. Status and future of global and regional ocean prediction systems. Journal of Operational Oceanography 8, s201-s220. URL: https://doi.org/10.1080/1755876X.2015.1049892, doi:10. 1080/1755876X. 2015. 1049892, arXiv: https://doi .org/10. 1080/1755876X. 2015. 1049892.

Toompuu, A., Wulff, F., 1996. Optimum spatial analysis of monitoring data on temperature, salinity and nutrient concentrations in the Baltic Proper. Environmental Monitoring and Assessment 43, 283-308. URL: https://doi.org/ 10.1007/BF00394455, doi:10.1007/BF00394455.

Treguier, A.M., Chassignet, E.P., Boyer, A.L., Pinardi, N., 2017. Modeling and forecasting the "weather of the ocean" at the mesoscale. Journal of Marine Research 75 . 
Tsumune, D., Tsubono, T., Aoyama, M., Hirose, K., 2012. Distribution of oceanic ${ }^{137}$ Cs from the Fukushima Dai-ichi Nuclear Power Plant simulated numerically by a regional ocean model. Journal of Environmental Radioactivity 111, 100 108. URL: http://www.sciencedirect.com/science/article/pii/S0265931X11002463, doi:https://doi.org/10.1016/j . jenvrad.2011.10.007. environmental Impacts of the Fukushima Accident (Part I).

Tuomi, L., 2014. On modelling surface waves and vertical mixing in the Baltic Sea. Ph.D. thesis. URL: http://urn.fi/URN:ISBN:978-951-697-810-2.

Tuomi, L., Myrberg, K., Lehmann, A., 2012. The performance of the parameterisations of vertical turbulence in the 3D modelling of hydrodynamics in the Baltic Sea. Continental Shelf Research 50-51, $64-79$. URL: http://www.sciencedirect.com/science/article/pii/S027843431200221X, doi:https: //doi.org/10.1016/j.csr.2012.08.007.

Tyrrell, T., 1999. The relative influences of nitrogen and phosphorus on ocean primary production. Nature 400, 525-531.

Uiboupin, R., Laanemets, J., Sipelgas, L., Raag, L., Lips, I., Buhhalko, N., 2012. Monitoring the effect of upwelling on the chlorophyll a distribution in the Gulf of Finland (Baltic Sea) using remote sensing and in situ data. Oceanologia 54, 395 - 419. URL: http://www.sciencedirect.com/science/article/ pii/S0078323412500205, doi:https ://doi.org/10.5697/oc. 54-3.395.

Uotila, J., Launiainen, J., Vihma, T., 1995. Analysis of the surface drift currents in the Bothnian Sea. Geophysica 31, 37-49.

Vahtera, E., Autio, R., Kaartokallio, H., Laamanen, M., 2010. Phosphate addition to phosphorus-deficient Baltic Sea plankton communities benefits nitrogenfixing cyanobacteria. Aquatic Microbial Ecology 60, 43-57.

Vahtera, E., Laanemets, J., Pavelson, J., Huttunen, M., Kononen, K., 2005. Effect of upwelling in the pelagic environment and bloom-forming cyanobacteria in the western Gulf of Finland, Baltic Sea. Journal of Marine Systems 58, 67-82.

Viktorsson, L., Almroth-Rosell, E., Tengberg, A., Vankevich, R., Neelov, I., Isaev, A., Kravtsov, V., Hall, P.O.J., 2012. Benthic phosphorus dynamics in the Gulf of Finland, Baltic Sea. Aquatic Geochemistry 18, 543-564. URL: https://doi.org/ 10.1007/s10498-011-9155-y, doi:10.1007/s10498-011- 9155 - y.

Wang, X., Chao, Y., Thompson, D.R., Chien, S.A., Farrara, J., Li, P., Vu, Q., Zhang, H., Levin, J.C., Gangopadhyay, A., 2013. Multi-model ensemble forecasting and glider path planning in the Mid-Atlantic Bight. Continental Shelf Research 63, S223 - S234. URL: http://www.sciencedirect.com/science/article/ pii/S0278434312001896, doi:https ://doi.org/10.1016/j.csr.2012.07. 006. coastal Ocean Observing System: Retrospective Reanalysis and Real-Time Forecasting.

Wasmund, N., Nausch, G., Voss, M., 2012. Upwelling events may cause cyanobacteria blooms in the Baltic Sea. Journal of Marine Systems 90, 67 - 76. URL: http://www.sciencedirect.com/science/article/pii/S0924796311002016, doi:https://doi.org/10.1016/j.jmarsys.2011.09.001.

Westerlund, A., 2018. Modelling circulation dynamics in the northern Baltic Sea. Ph.D. thesis. URL: http://urn.fi/URN:ISBN:978-952-336-055-6. 
Westerlund, A., Tuomi, L., 2016. Vertical temperature dynamics in the Northern Baltic Sea based on 3D modelling and data from shallow-water Argo floats. Journal of Marine Systems 158, 34 - 44. URL: http://www. sciencedirect.com/science/article/pii/S0924796316000191, doi:https://doi.org/ 10.1016/j . jmarsys . 2016.01.006.

Wilks, D., 2011. Chapter 8 - forecast verification, in: Wilks, D.S. (Ed.), Statistical Methods in the Atmospheric Sciences. Academic Press. volume 100 of International Geophysics, pp. 301 - 394. URL: http://www. sciencedirect.com/science/article/pii/B9780123850225000087, doi:https://doi. org/10.1016/B978- 0-12-385022-5.00008- - .

Williams, N.L., Juranek, L.W., Feely, R.A., Johnson, K.S., Sarmiento, J.L., Talley, L.D., Dickson, A.G., Gray, A.R., Wanninkhof, R., Russell, J.L., Riser, S.C., Takeshita, Y., 2017. Calculating surface ocean $\mathrm{pCO}_{2}$ from biogeochemical Argo floats equipped with $\mathrm{pH}$ : An uncertainty analysis. Global Biogeochemical Cycles 31, 591-604. URL: https://agupubs.onlinelibrary. wiley.com/doi/abs/10.1002/2016GB005541, doi:10.1002/2016GB005541, arXiv: https://agupubs. onlinelibrary.wiley.com/doi/pdf/10.1002/2016GB005541.

Witting, R., 1912. Zusammenfassende übersicht der Hydrographie des Bottnischen und Finnischen Meerbusens und der Nördlichen Ostsee. Finnländische hydrographisch-biologische Untersuchungen 7.

Wong, A.P.S., Riser, S.C., 2011. Profiling float observations of the upper ocean under sea ice off the Wilkes Land coast of Antarctica. Journal of Physical Oceanography 41, 1102-1115. URL: https://doi.org/10.1175/2011JPO4516.1, doi:10.1175/2011JP04516.1, arXiv:https://doi.org/10.1175/2011JP04516.1.

Wong, A.P.S., Riser, S.C., 2013. Modified shelf water on the continental slope north of Mac Robertson Land, East Antarctica. Geophysical Research Letters 40, 6186-6190. URL: https://agupubs.onlinelibrary. wiley.com/doi/abs/10.1002/2013GL058125, doi:10.1002/2013GL058125, arXiv: https://agupubs . onlinelibrary.wiley. com/doi/pdf/10. 1002/2013GL058125.

Xing, X., Morel, A., Claustre, H., Antoine, D., D’Ortenzio, F., Poteau, A., Mignot, A., 2011. Combined processing and mutual interpretation of radiometry and fluorimetry from autonomous profiling Bio-Argo floats: Chlorophyll a retrieval. Journal of Geophysical Research: Oceans $116 . \quad$ URL: https://agupubs.onlinelibrary. wiley.com/doi/abs/10.1029/2010JC006899, doi:10.1029/2010Jc006899, arXiv: https://agupubs . onlinelibrary.wiley. com/doi/pdf/10.1029/2010Jc006899.

Zhurbas, V., Laanemets, J., Vahtera, E., 2008. Modeling of the mesoscale structure of coupled upwelling/downwelling events and the related input of nutrients to the upper mixed layer in the Gulf of Finland, Baltic Sea. Journal of Geophysical Research: Oceans 113. URL: https://agupubs.onlinelibrary. wiley.com/doi/abs/10.1029/2007JC004280, doi:10.1029/2007Jc004280, arXiv: https://agupubs. onlinelibrary.wiley. com/doi/pdf/10.1029/2007Jc004280.

Österblom, H., Hansson, S., Larsson, U., Hjerne, O., Wulff, F., Elmgren, R., Folke, C., 2007. Human-induced trophic cascades and ecological regime shifts in the Baltic Sea. Ecosystems 10, 877-889. URL: https://doi.org/10.1007/ s10021-007-9069-0, doi:10.1007/s10021- 007-9069- 0. 


\section{Licences \& Permissions}

\section{Publications}

Publication I (c)2018 The Authors. Published by Informa UK Limited, trading as Taylor \& Francis Group. This is an Open Access article distributed under the terms of the Creative Commons Attribution License (http://creativecommons.org/licenses/by/4.0/), which permits unrestricted use, distribution, and reproduction in any medium, provided the original work is properly cited.

Publication II and III (c)2018 The Authors. Both are open-access articles distributed under the terms of the Creative Commons Attribution License (CC BY). The use, distribution or reproduction in other forums is permitted, provided the original author(s) and the copyright owner(s) are credited and that the original publication in this journal is cited, in accordance with accepted academic practice. No use, distribution or reproduction is permitted which does not comply with these terms.

Publication IV is reproduced with the permission of the Taylor \& Francis Group.

Publication V is reproduced with the permission of Elsevier, B.V.

\section{Data}

The Argo data were collected and made freely available by the International Argo Project and the national programmes that contribute to it (http://www.argo.ucsd.edu, http://argo.jcommops.org). Argo is a pilot programme of the Global Ocean Observing System.

The satellite SST data is available under Creative Commons By 4.0 International license and is processed by Finnish Environment Institute. 
Licences \& Permissions 


\section{Publication I}

Simo Siiriä, Petra Roiha, Laura Tuomi, Tero Purokoski, Noora Haavisto and Pekka Alenius. Applying area-locked, shallow water Argo floats in Baltic Sea monitoring. Journal of Operational Oceanography, 1-15, doi:10.1080/1755876X.2018.15447832018. 



\title{
Applying area-locked, shallow water Argo floats in Baltic Sea monitoring
}

\author{
Simo Siiriä (D), Petra Roiha (D), Laura Tuomi (D), Tero Purokoski, Noora Haavisto and Pekka Alenius (D) \\ Finnish Meteorological Institute, Helsinki, Finland
}

\begin{abstract}
Argo floats have been successfully used for more than 10 years in the world's ocean. The Finnish Meteorological Institute began to develop practices to use Argo floats in the shallow brackish water Baltic Sea in 2011. Since 2012, Argo floats have been in continuous use in the Baltic Sea and are now a part of the Euro-Argo European Research Infrastructure Consortium (ERIC). The floats are kept in the different basins of the Baltic Sea, usually for a year and then recovered and replaced with a new float. The observation cycle is usually a week in monitoring mode, but we have also used shorter intervals up to one day. With proper piloting practices, Argo floats are of great value in monitoring and for research of shallow marginal seas, as they give regular and frequent data around the year, regardless of weather conditions. Operating the floats has matured to a level where we can state that Argo monitoring of the Baltic Sea is an operative reality.
\end{abstract}

\section{ARTICLE HISTORY}

Received 6 June 2018

Accepted 30 October 2018

\section{KEYWORDS}

Argo; stratification; oxygen; monitoring; baltic sea; water masses

\section{Introduction}

Argo floats are an essential component of the global ocean observing system, as they provide a large amount of data with high temporal and spatial resolution at relatively low cost (Riser et al. 2016). Until recent years, their use on marginal seas have been scarce, as the typical mode of operation expects a depth of $2 \mathrm{~km}$ and a large area.

The semi-enclosed, shallow, brackish water Baltic Sea is a European marginal sea that suffers from serious environmental problems, mainly eutrophication. The population in the catchment area is around 85 million inhabitants, and the sea is important for the coastal countries. Therefore the environmental conditions of the Baltic Sea have been monitored in international cooperation under the Baltic Sea Environment Protection Commissions - Helsinki Commission (HELCOM) monitoring programs since 1979 (HELCOM 2017). All the coastal countries of the Baltic Sea are members of HELCOM. Today the HELCOM hydrography and chemistry monitoring dataset also includes all earlier observations from the monitoring stations, so there is data since 1898. The data is available at International Council for the Exploration of the Sea - ICES (www. ices.dk).

The Baltic Sea consists of a series of basins that are mostly separated by underwater sills. The limited connection to the North Sea through the narrow and shallow Danish straits have a great effect on the hydrography and consequently on the ecosystem health of the Baltic Sea. The halocline, usually located between 40-80 $\mathrm{m}$ depth, typically isolates the deep water from the upper layer that overturns seasonally. The deep water masses in the southern and central Baltic and in the western Gulf of Finland renew only when large amounts of more saline- and oxygen-rich waters flow to the Baltic Sea from outside as Major Baltic Inflows (MBIs). The frequency of MBIs has been variable, but after the mid 1970s there have been few episodes (Matthäus 2006).

Seasonal thermocline develops in spring and reaches 15-30 $\mathrm{m}$ depth in late summer. It erodes in the autumn due to cooling and wind-induced mixing. The dynamics of the forming and eroding of the mixed surface layer has a great influence on various biological processes and the carbon interactions on the Baltic Sea. Modelling the mixed layer is also still a challenge (Tuomi et al. 2012; Dietze and Löptien 2016). Argo observations complement monitoring of these processes and can give valuable information on the stratification of the Baltic Sea (e.g. Westerlund and Tuomi 2016).

The Gotland Deep is a relatively small deep area surrounded by shallower areas. The over $150 \mathrm{~m}$ deep part of the basin is roughly $80 \mathrm{~km}$ long and $40 \mathrm{~km}$ wide and includes the second deepest part of the Baltic proper (c. $250 \mathrm{~m}$ ). This makes it an ideal place to test whether an Argo float can be confined in a closed area.

CONTACT Simo Siiriä 8 simo.siiria@fmi.fi $=$ Finnish Meteorological Institute, Erik Palménin aukio 1, P.0 Box 503, Fl-00101 Helsinki, Finland () 2018 The Author(s). Published by Informa UK Limited, trading as Taylor \& Francis Group This is an Open Access article distributed under the terms of the Creative Commons Attribution License (http://creativecommons.org/licenses/by/4.0/), which permits unrestricted use, distribution, and reproduction in any medium, provided the original work is properly cited. 
There is a permanent halocline at $60-80 \mathrm{~m}$ depth, which is also a pycnocline where the density difference across it is around $2.5 \mathrm{~kg} / \mathrm{m}^{3}$. This pycnocline restricts the penetration of wind-induced mixing and seasonal overturning of the upper layers to the deeper layers. Therefore the deep layers of the Gotland Deep and some other sub-basins suffer from hypoxia in stagnation periods when MBIs do not happen. During the stagnation periods, the water below the halocline renews mainly by diffusion, which is a slow process. For example, in the Gotland Deep the water age in the bottom layer during stagnation periods is about 5 years (Meier et al. 2006).

Observation station BY15 in the Gotland Deep (57.32 $\mathrm{N} 20.05 \mathrm{E}$ ) is one of the most visited monitoring stations in the Baltic Sea Proper, and it is a benchmark of the state of the Baltic Sea. A profiling mooring station has also been used in the area (Prien and Schulz-Bull 2016). HELCOM member countries are committed to visit it at least once a month. The number of visits reported to HELCOM has been on average 20 per year since 1963 and almost 30 per year in the 2000s. Thus the evolution of hydrochemical conditions from the surface down to the bottom are considered to be well-known there. The importance of the processes affecting the deep water oxygen conditions justifies even more frequent monitoring of that important area to catch the details of those processes.

FMI has been operating Argo floats in the Baltic Sea since 2012 (Purokoski et al. 2013). In this paper, we will present Argo float data around the Gotland Deep and demonstrate how the floats can be kept in a confined area for a year or more to collect time-series data. While not completely stationary in position, a float operated this way collects data that can be used for monitoring temporal and spatial changes of the ocean properties.

We evaluate the quality of the Argo measurements compared to traditional monitoring. We also demonstrate the benefits of measuring with high temporal resolution with the results from the data collected after the Major Baltic Inflows and data on mixed layer formation and oxygen interactions. The extra benefit of using Argo floats is that we can react to changes in environmental conditions for example by shortening the time step between profiles during intensive storms.

\section{Operating Argo floats in the Baltic Sea}

Typical Argo floats are constructed to be deployed in oceans, where they spend most of their time drifting in the depth of $1000 \mathrm{~m}$. Usually they do profile measurements from $2000 \mathrm{~m}$ to the surface once every 10 days
(Le Traon 2013). The alkaline battery used in the floats offers approximately 150 such cycles. They complete the measurements with little or no user interference after deployment. At the end of its mission, the float runs out of battery power and sinks to the ocean bottom. Typical oceanic deployment areas are free of ice and deep enough that the float has no risk of hitting the bottom during normal operations.

We have used Teledyne Webb research APEX floats in our operations. The Gotland Deep floats have been Bio-Argo floats with the following sensors:

\section{- SBE 41CP CTD}

- Aanderaa optode 4330 oxygen sensor

- Wetlabs FLBB-AP2 turbidity and fluorescence sensor

The manufacturer states that the alkaline batteries of the float will provide up to 4 years or 150 profile lifetimes in ocean conditions (Table 1).

The floats can change their density up to $9 \mathrm{~kg} / \mathrm{m}^{3}$. The Baltic Sea has strong vertical density gradients, and the densities also differ horizontally from basin to basin, with surface densities roughly from 1005 to $1010 \mathrm{~kg} / \mathrm{m}^{3}$ (Leppäranta and Myrberg 2009). The density changes within one profile due to salinity and temperature differences are on the same scale as the float's ability to change density. For this reason, it is important to balance the float to match the expected densities of the target area. The floats we used were ordered as balanced for the target area by the manufacturer.

When defining the deployment site, a suggested method is to choose a place where the depth is among the deepest points of the intended operating area. At the start of the mission, the float first checks its depth every two hours to see if it should activate itself. Therefore the original buoyancy must be set large enough for it to evade the bottom before it activates, and low enough to ensure that it descends down to at least $25 \mathrm{dbar}$ pressure level to make it wake up.

The profiling cycle in our measurements consists of:

(1) descending to the parking depth

(2) drifting at the parking depth measuring pressure, salinity and temperature

(3) ascending to the surface, measuring the profile with all available instruments

Table 1. Argo missions in the Gotland Deep.

\begin{tabular}{lccccc}
\hline $\begin{array}{l}\text { WMO } \\
\text { number }\end{array}$ & Deployed & Recovered & $\begin{array}{c}\text { Active } \\
(\mathrm{d})\end{array}$ & $\begin{array}{c}\text { Avg.depth } \\
(\mathrm{m})\end{array}$ & Profiles \\
\hline 6902014 & $2013-08-14$ & $2014-08-21$ & 372 & 121 & 93 \\
6902019 & $2014-08-21$ & $2015-08-05$ & 348 & 168 & 62 \\
6902020 & $2015-08-05$ & $2016-08-03$ & 363 & 203 & 68 \\
\hline
\end{tabular}


(4) sending the data and receiving new instructions with IRIDIUM satellites

In oceans, before the ascent, the float dives first from the parking depth down to usually a $2 \mathrm{~km}$ depth before making the profile. In shallow seas, this step is not practical because the drifting depth is already close to the bottom. The Baltic Sea is on average only $54 \mathrm{~m}$ deep with a maximum depth of $459 \mathrm{~m}$.

The main concern for further diving depths is twofold:

(1) Bottom contacts should be avoided, as muddy bottom can get the float stuck.

(2) The float should dive close enough to the bottom, as it will then stay better in the designated area and measure the whole profile to as great a depth as possible.

During this work, we determined the two most common cases when the bottom contacts occur: First, if the initial deployment density of the float is considerably larger than the density at the bottom of the location. Similar risk occurs if the target diving pressure is set higher than the water density at the bottom of the measurement area. In that case, the float will increase its density to the maximum as it tries to descend beyond the bottom. In addition to the risk of losing the float, this unnecessarily consumes the batteries.

The most often-used cycle length in the Gotland Deep missions was one week. The ascent from parking depth to the surface and measuring the profile took roughly $2.5 \mathrm{~h}$. The communication took typically something between 15 and $45 \mathrm{~min}$, depending on how quickly the float could establish the contact. For most of the cycle time, the float drifts in the parking depth. Diving cycles are planned to have surfacing times at nights. This minimises the chances of collisions with small boats or someone picking it up.

We found out during this work that the float can be kept within the deep area around the deployment point by adjusting the parking depth deep enough to follow lower layer currents but at the same time avoiding bottom contacts. The pilot of the float must anticipate the conditions in the target area till the next surfacing, as the float receives instructions only at the surface. We determined the parking depths using the floats lastknown position, the bathymetry from marine charts at that location and weather forecasts for the time of surfacing.

If there arises a need to change the parking depth before the next scheduled measurement, the pilot can shorten the observation cycle. Our experiences showed that strong surface currents could make the float drift on the surface farther than intended. Such conditions need to be recognised from the weather forecasts beforehand in order to shorten or lengthen the surfacing time to either avoid the surface drift or to use it in letting the float drift to the desired direction at the surface.

Our experience from the beginning of the operation up to now has shown that if the float is kept deep enough, the deep currents following the bathymetry tend to keep it in the closed area. In the Baltic Sea, the bottom boundary layer is often interesting, and there is a scientific risk when the float is kept too safe leaving the interesting near-bottom layer unobserved.

Seasonal ice cover is an extra challenge for the yearround operations, especially in the northern areas of the Baltic Sea, as the float cannot communicate when under ice, and a collision with the ice cover can harm the sensors. For these reasons, a float designed to operate in such an area must be able to detect the ice before collisions and may need to stay months without the possibility to change instructions.

As of the writing of this paper, we have completed four different Argo missions in the Gotland Deep with two Argo floats. Here we look in detail at the data from the three first missions during 2013-2015, which show the evolution of the operational process and some interesting cases. All float missions in the Argo program are identified by their individual WMO numbers. Coriolis service (Coriolis 2001) offers the data publicly available from a single source according to the WMO numbers. Our missions which we analyse here had the WMO numbers 6902014, 6902019 and 6902020. Of these, 6902014 and 6902020 are performed with the same float. The relatively compact size of the Baltic Sea makes retrieval of the floats possible during regular monitoring cruises or with the help of the coast guard.

\section{Data acquired from the Gotland Basin}

\subsection{Overview}

Here we use data from three Argo float missions in the Gotland Deep area. The deployment times and average profile depths are presented in Table 1. Originally, floats measured salinity as PSU and oxygen concentration as $\mu \mathrm{mol} / \mathrm{kg}$. Absolute salinity and oxygen concentration in $\mathrm{ml} / \mathrm{l}$ for the Argo and CTD profiles were calculated using the Python implementation (https:// anaconda.org/pypi/gsw) of the Thermodynamic Equation of Seawater - 2010, TEOS-10 (IOC, SCOR, IAPSO 2010). 


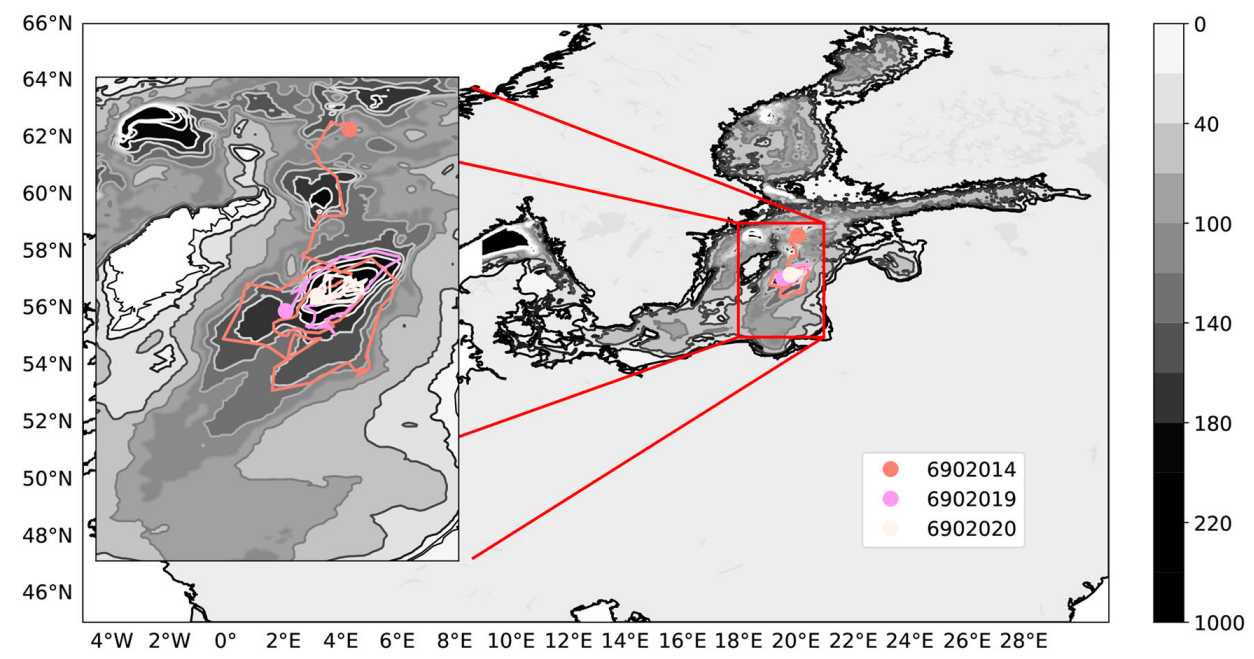

Figure 1. Routes of the Argo floats near the Gotland Deep (left) and the location of the Gotland Basin on the Baltic Sea (right). The routes are identified by their WMO number. Topography data iowtopo2 (Seifert et al. 2001).

The floats have stayed relatively well in the deep areas of the Gotland Deep (Figure 1). The first float escaped from the area around May 2014. It escaped partly due to diving depth that was too low and partly due to the strong winds during the time.

Usually the floats measured one profile per week. After deployments and in some high wind events, we changed to daily profiling to get better time resolution of the data and to keep control of the floats. On average, the diving depth within the study period was $160 \mathrm{~m}$ with a minimum of $100 \mathrm{~m}$ and a maximum of $210 \mathrm{~m}$. The average diving depth was increased with each mission from 121 to $168 \mathrm{~m}$, then to $203 \mathrm{~m}$ as we grew more experienced in operating the Argo floats.

Data from the three missions was combined into one time series (Figure 2). From this series, we can see the seasonal stratification patterns, oxygen behaviour (Section 5.2) and inflow events (Section 5.1).

\subsection{Diving depth and bottom contacts}

The mission profile depths, approximated bathymetry (Seifert et al. 2001), and float cycles with bottom contacts are shown in Figure 3. The average profile depth was increased from first to last mission by approximately $75 \mathrm{~m}$, as can be seen in Figure 3. The grey areas show cycles with bottom contacts, and thus the profile depth at those times gives accurate bathymetry information. The bottom contacts were determined from the float's drifting data by assuming that if the float parking depth varies less than $0.05 \mathrm{~m}$ during $10 \mathrm{~h}$, the float was at the bottom. The resolution of the reference bathymetry data used is about $1 \mathrm{nmi}$. On average, the distance between the float coordinates and the closest bathymetry grid point was $730 \mathrm{~m}$. The float depth during the bottom contact mostly corresponds well with the closest bathymetric data.

The number of bottom contacts changed considerably from one float to another. The First one managed to avoid them until it drifted to north to a shallower area. Of the 93 profiles, 24 had a bottom contact. The second mission had slightly more bottom contacts ( 23 of the 63 profiles). The float managed to rise from the bottom without problems after each contact, even if the general type of bottom in the area were muddy (Winterhalter et al. 1981, Figure 140a). With the experience gained from the first bottom contacts, the risk of getting stuck to the bottom was deemed minor in the float's operating area. Based on this, we decided to keep the float close to the bottom to prevent it from escaping from the desired area.

With the third mission, the diving depth was successfully chosen, preventing the float from drifting into areas that were too shallow. As such, it had bottom contact in only 8 of the 68 profiles.

During these missions, the practice of operating shallow Argo floats was developed and improved. With the increased knowledge of the float behaviour, we were able to keep the float deeper with every mission. The initial mission had an average diving depth of $121 \mathrm{~m}$, the second $169 \mathrm{~m}$ and the third $204 \mathrm{~m}$. Initially, we limited the diving depth as we were over-cautiously avoiding the bottom contacts. This led on the first mission to the escaping from the designated deep area, and thus a further need for shallower dives. With the second float, we increased 

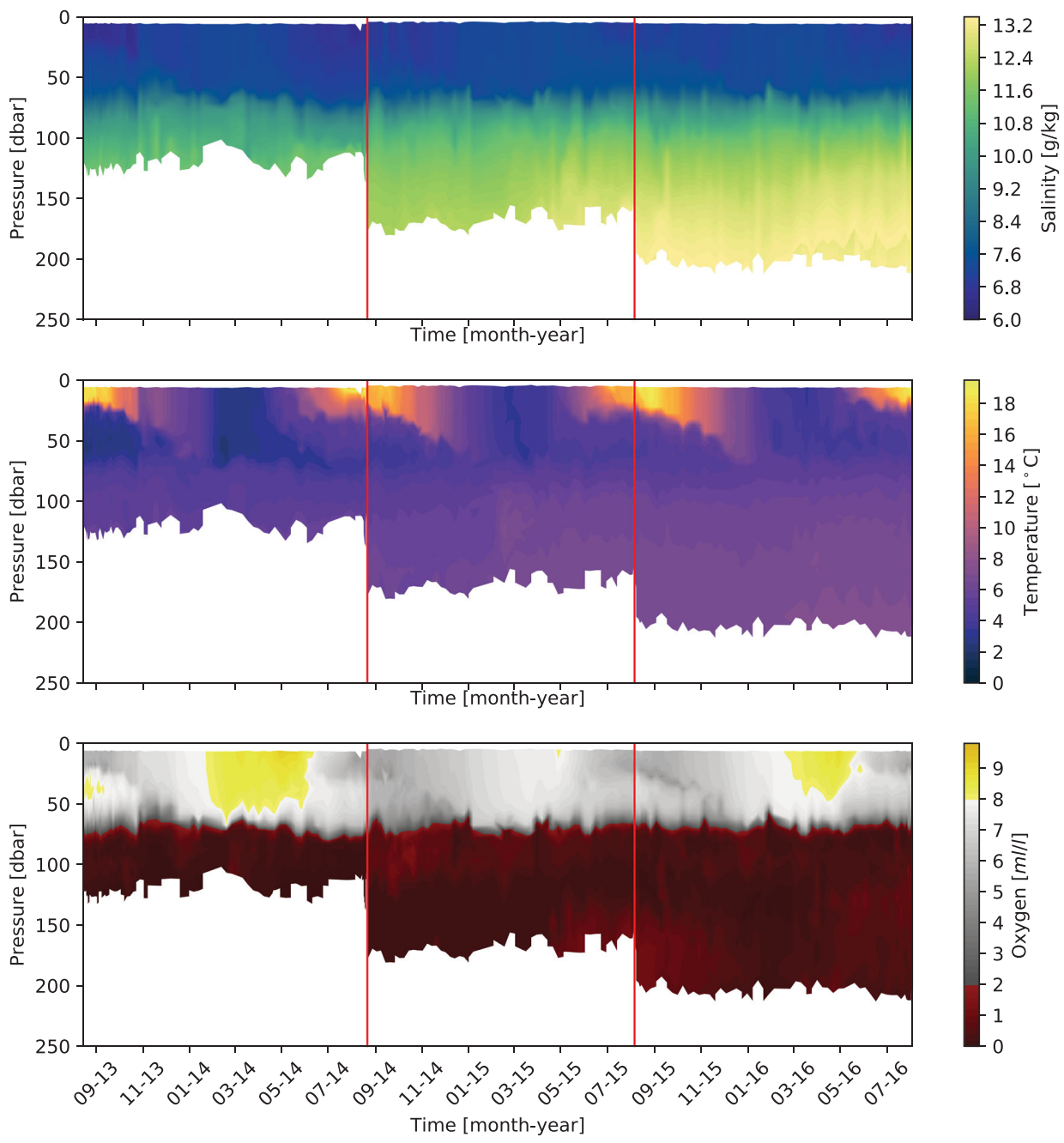

Figure 2. Measurements of the three Argo missions studied. Salinity (up), temperature (middle) and oxygen (bottom). Red lines indicate float changes.

the diving depth, which kept it in the deeper area, but it ended up having a considerable number of bottom contacts. In the third one, we increased the diving depth further, and thus managed to keep the float deep enough to stay in its designated area and thus having less bottom contacts, as it remained mostly in the deepest area.

\subsection{Deployment and operating area}

The floats were deployed and recovered during R/V Aranda's annual COMBINE monitoring cruises. The active float was recovered, and another float was put instead. All three floats were deployed at $5 \mathrm{~km}$ from the first deployment point $\left(20^{\circ} 2^{\prime} \mathrm{E} 57^{\circ} 19^{\prime} \mathrm{N}\right)$.
The distance of the floats from their original point of deployment can be seen in Figure 4. After staying in the area over half a year, the first float escaped the deployment area in May 2014, ending up over $100 \mathrm{~km}$ north from the point of deployment (see Figure 4). The other two floats stayed mostly within $40 \mathrm{~km}$ of the deployment point during their entire mission.

\subsection{Faulty measurements and quality control}

The Coriolis data centre has quality-controlled the data on their system for consistency in for example timestamps and locations, and marked them with quality flags. For ocean profiles, Coriolis also performs 


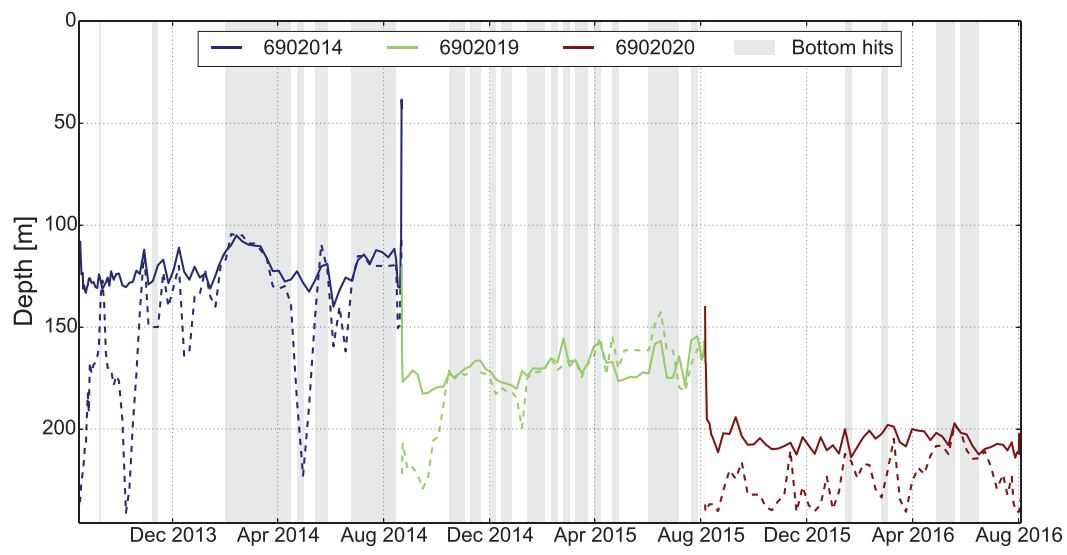

Figure 3. Profile depth (solid lines) and approximated bathymetry along the float drift route (dashed lines) during different missions (colours). The shaded grey areas show float cycles with bottom contact at some point during the cycle. Bathymetry approximated from the Leibniz Institute for Baltic Sea Research (IOW) bathymetry dataset (Seifert et al. 2001).

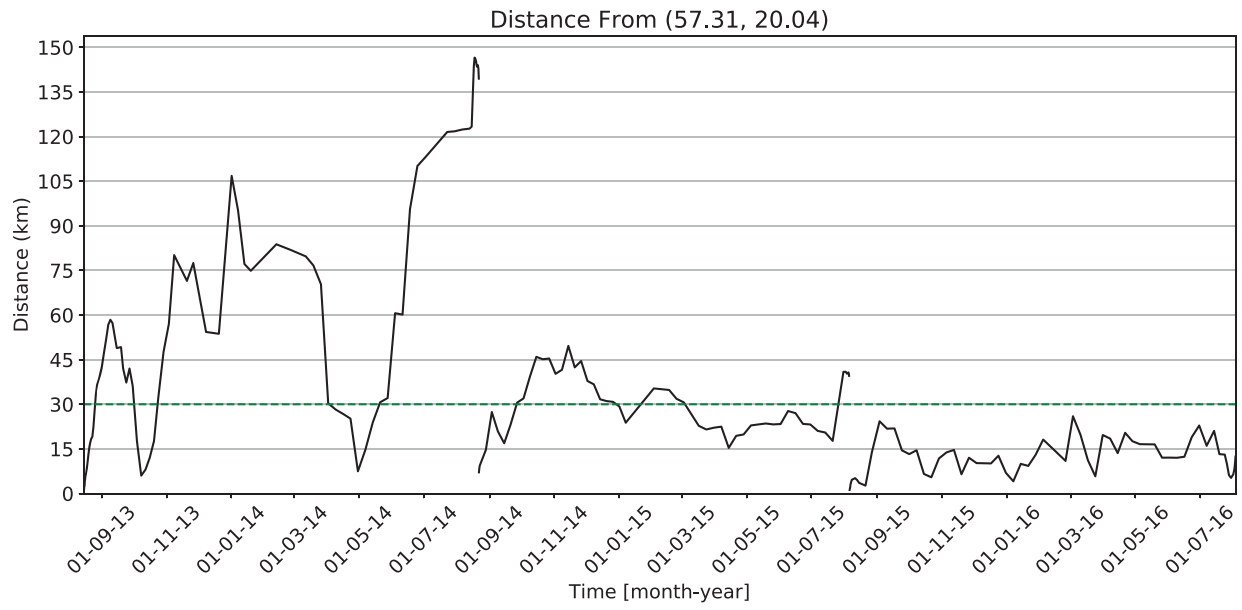

Figure 4. The distance of the float from the original deployment point as a function of time. The green line marks the $30 \mathrm{~km}$ distance.

numerous quality control steps (Carval et al. 2017), incompatible for the Baltic Sea, as the profiles differ considerably from the ocean profiles. As such, we removed faulty profiles with the quality control described below:

Most of the profiles were measured successfully. However, in some cases the CTD sensor had probably been clogged. These can be identified if either surface salinity exceeded 7.5 or if the salinity dropped quickly between two measurements. Here the limit of a quick sudden drop was set to $0.3 \mathrm{~g} / \mathrm{kg}$ between two measurements if the following and previous measurement changes were less than $0.03 \mathrm{~g} / \mathrm{kg}$. This was set to not reject a profile with a strong halocline, as a real one would be visible in more than one consecutive measurement. In total,
12 out of 446 profiles $(\approx 3 \%)$ were marked as flawed. This method detects clearly faulty profiles, but does not ensure all clogged measurements are detected, especially if the fault has been just temporal.

The recovered floats were sent back to the manufacturer where they were inspected, their sensors calibrated, maintenance-serviced, batteries replaced, and sent back to us so that we could deploy them again.

\section{Argo data compared to other monitoring data}

As Baltic Sea Argo floats are part of the global Argo program for monitoring the World Ocean, it is natural to 
reflect their data against the data from regular monitoring cruises of the Baltic Sea, which is done within the HELCOM cooperation. HELCOM has many monitoring programs, and from those we refer to the Cooperative Monitoring in the Baltic Marine Environment (COMBINE) and to the data that is publicly available from the ICES data centre as a dataset by the HELCOM area.

The COMBINE program has two types of observing stations: mapping stations and high-frequency stations (HELCOM 2017). The data consists of water sample data and CTD measurements collected by various countries and institutions. The HELCOM dataset is now maintained at the ICES data centre, and it includes data since 1898 from HELCOM monitoring stations listed in the ICES station dictionary (http://ices.dk/ marine-data/tools/pages/station-dictionary.aspx). The mapping stations are visited only a couple of times per year, and the high-frequency stations are aimed at giving information on the annual course of the processes.

The HELCOM dataset is a subset of ICES CTD and bottle data, which also contains data from stations other than the HELCOM monitoring stations. That data is also publicly available from ICES. Because we wanted to compare our Argo data to data from ship observations as near to the Argo profiles as possible, we downloaded the relevant ICES data for our comparisons. Figure 6 shows the locations of CTD measurements in the ICES data and the locations of our Argo profiles studied here.

The most consistent fixed location time series from the Gotland Deep HELCOM monitoring station BY15 consists of on average two profiles per month during the Argo operational period (Figure 5). From the 1960s

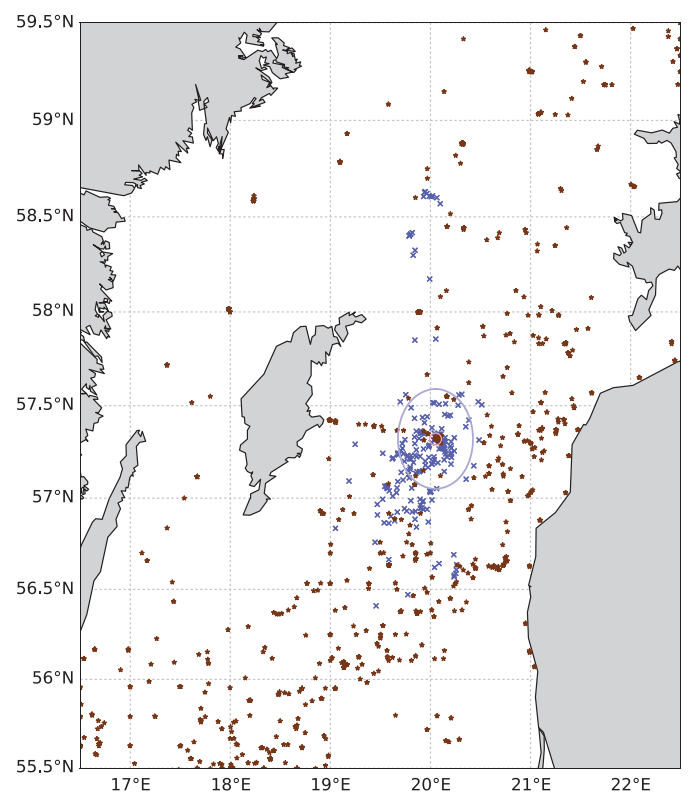

Figure 6. Locations of CTD profiles from ICES data (red stars) and Argo profiles (blue crosses) studied in this paper. The Most frequent measuring point, BY15 (57.32 N 20.05 E), which is also the starting point of all three Argo missions, is marked with a light red circle. The light blue circle marks the $30 \mathrm{~km}$ radius from the By15.

to the early 2000s the profiling frequency at BY15 increased from one to four profiles per month, after which it decreased to the present two per month. The Argo float profiles nearby the monitoring station therefore more than doubles the temporal data coverage

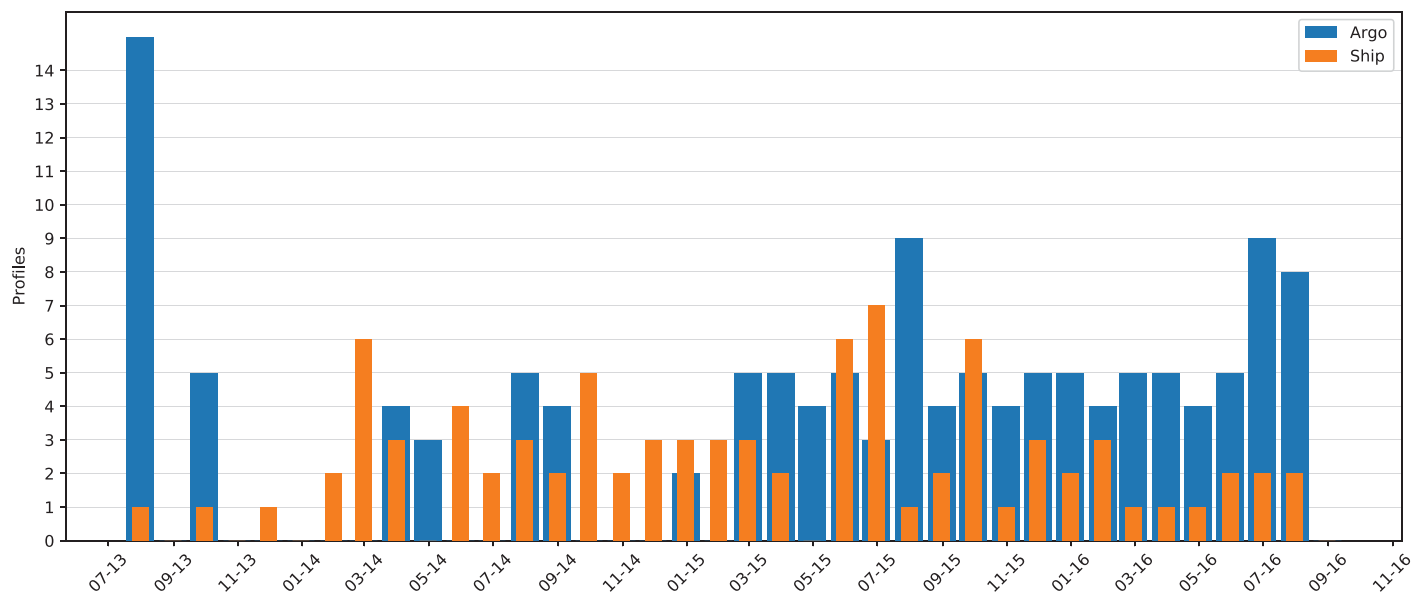

Figure 5. Number of Argo and shipborne CTD profiles per month $30 \mathrm{~km}$ from HELCOM monitoring station BY15 (57.32 N 20.05 E) for the study period. 

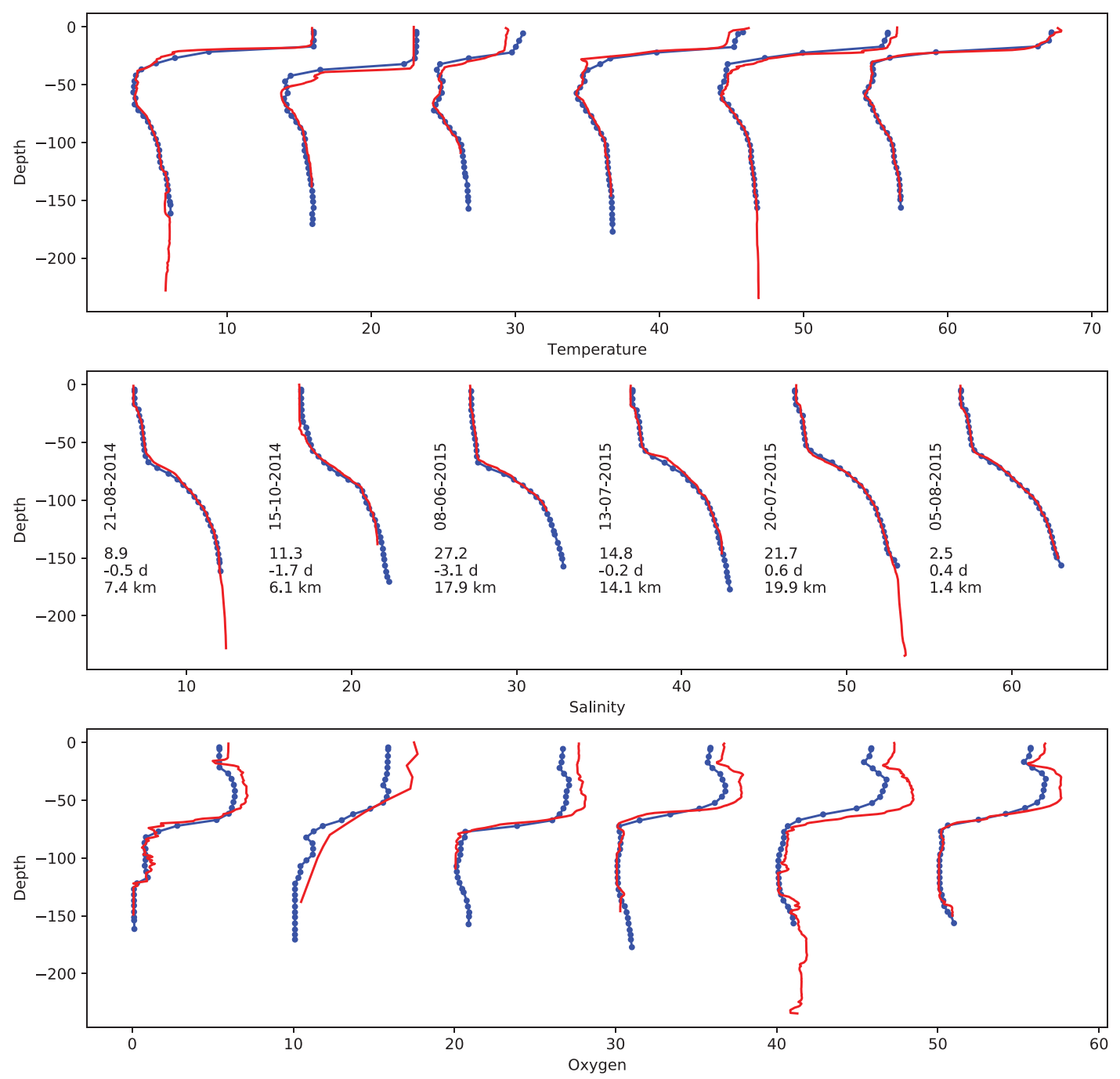

Figure 7. Best CTD matches for Argo 6902019. Temperature (a), salinity (b) and oxygen(c) are represented. Red indicates CTD measurements, Blue Argo. Each profile is shifted 10 units on their respective x-axis from the next one. The date of the Argo measurement is next to each salinity profile. Numbers under the date indicate the relative distance from the ship CTD, distance in days and distance in km. Negative day difference indicates an Argo float measurement earlier than the ship CTD.

there. This added frequency helps studying events taking days or weeks, like stratification, and increase the chances of getting measurements of shorter incidents like storm-induced mixing. In Section 5, we consider some of the phenomena detected.

The advantage of the monitoring points, compared to the Argo measurement, is their consistency in place. With the Argo floats, we need to consider more of the drift in both time and location.
To validate Argo measurements against CTD, we searched the closest matches from both datasets both in time and location, and we checked how different the given results were on average. To determine the closest pair, we used the relative distance $\left(D_{r}\right)$, which was determined as:

$$
D_{r}=D_{k m}+3 \frac{k m}{d} \cdot D_{d}
$$


Where $D_{k m}$ is the distance of measuring points in kilometres, and $D_{d}$ is their distance in days. The constant 3 was chosen for the equation after testing, as $3 \mathrm{~km} / \mathrm{d}$ is in the range of drifting speeds of the floats in the area, and it gave a reasonable compromise between distances in days and kilometres. Figure 7 shows examples of the best matches for the float 6902019 .

We got closer matches between the Argo float and ship profiles in later missions as we gained more experience in operating the floats. We managed to increase the average diving depth with each mission and thus keep the floats more confined, which increased the amount of concurrent ship CTDs, as the float stayed closer to the BY15.

Each Argo profile was paired with the closest (smallest $D_{r}$ ) ship CTD. This often means that the same ship CTD will be the best match for several Argo profiles, especially on occasions when the Argo float measured once a day, during deployment and pick-up. This would cause most of the best matches to describe the same situation, which is undesired. For this reason, for the pairs with the same ship CTD, we only picked for further analysis the one with smallest $D_{r}$. This left us with 18,14 and 25 unique pairs for each mission. Of these, we picked for analysis the ones with $D_{r}<35.0$, leaving 6,7 and 20 profiles, respectively (Table 2). The importance of the measuring point BY15 in the comparisons shows for the first mission 3 out of 6 selected missions is within $10 \mathrm{~km}$ of it, and for the second and third missions the same rates are 2 out of 7 and 19 out of 20 , respectively.

The remaining pairs were used to get an idea of possible systematic bias in the measurements. The best matches for each float were less than two kilometres away and within a day; and for the last accepted, the higher distance was either under 10 days or $20 \mathrm{~km}$. With these distances, single profiles can have considerable differences, but the average differences are interesting to look at.

The biases are listed in Table 2. The depth studied were divided into surface layer $(0-30 \mathrm{~m})$ and bottom layer $(80-150 \mathrm{~m})$. The in-between area $(30-80 \mathrm{~m})$ was omitted, as it is less homogeneous and as such would

Table 2. Comparison of the bias between ship CTD measurements and Argo floats. Profile pairs with $D_{r}<35$ were used for analysis. Lower values of the first float have been omitted, as none of its profiles reached the full $150 \mathrm{~m}$ depth.

\begin{tabular}{|c|c|c|c|c|c|c|c|}
\hline \multicolumn{8}{|c|}{ Bias between CTD and Argo measurements } \\
\hline \multirow[b]{2}{*}{$\begin{array}{l}\text { Float } \\
\text { WMO }\end{array}$} & \multicolumn{3}{|c|}{ Surface layer (0-30 m) } & \multicolumn{4}{|c|}{ Bottom layer (80-150 m) } \\
\hline & $\begin{array}{c}\mathrm{O}_{2} \\
(\mathrm{ml} / \mathrm{l})\end{array}$ & $\begin{array}{c}\text { Salinity } \\
(\mathrm{g} / \mathrm{kg})\end{array}$ & $\mathrm{T}^{\circ} \mathrm{C}$ & $\mathrm{O}_{2}(\mathrm{ml} / \mathrm{l})$ & $\begin{array}{c}\text { Salinity } \\
(\mathrm{g} / \mathrm{kg})\end{array}$ & $\mathrm{T}^{\circ} \mathrm{C}$ & $\begin{array}{l}\text { Pair } \\
\text { No } \\
\end{array}$ \\
\hline 6902014 & 0.3 & -0.08 & -0.66 & - & - & - & 6 \\
\hline 6902019 & 1.1 & -0.05 & -0.10 & 0.17 & 0.05 & 0.03 & 7 \\
\hline 6902020 & 0.6 & -0.01 & -0.06 & 0.19 & -0.05 & -0.01 & 20 \\
\hline
\end{tabular}

require taking into account the properties of the sensors in much more detail. In addition the changes in location and time are more dominant in this layer. The bottom layer data was discarded from the first float, as its average diving depth was $121 \mathrm{~m}$, with no profiles covering the whole $80-150 \mathrm{~m}$ range.

Temperature and salinity differences between the Argo float and ship data are small, considering that the matches are not in exactly the same places or times. The biases are small, generally under $0.1^{\circ} \mathrm{C}$. The first float has the highest bias of $0.7^{\circ} \mathrm{C}$ on the surface layer, with also the highest average differences in the measurements. This is partly due to it escaping the Gotland Deep to the north, where there were fewer profiles to match, partly for the number of comparable profile pairs being only 6 .

The oxygen values in the upper layer in the first and last mission were $0.3-0.6 \mathrm{ml} / \mathrm{l}$, and on the middle float about $1 \mathrm{ml} / \mathrm{l}$ lower than the corresponding CTD measurements. The manufacturer gives an accuracy of $5 \%$ for the sensor (Aanderaa Data Instruments AS 2001). In the surface layer, with $\mathrm{O}_{2}$ of $8-10 \mathrm{ml} / \mathrm{l}$ these differences are within expectations, taking into account the differences in place and time for the first and third mission; but for the second mission, the oxygen values are lower than expected. This can also be seen from Figure 2, as oxygen in summer 2015 is lower than others in the Argo float measurements. Such a difference cannot be seen in ship CTD measurements. It seems that based on this, there are differences in the oxygen calibrations on the floats, which should be taken into account.

\section{Case studies in the Gotland Basin}

To show the potential of the Argo data in the Baltic Sea monitoring and research, we briefly deal with two case studies. The first case in the major Baltic inflow that occurred in December 2014. The other case is related to process studies and deals with upper-layer mixing.

\subsection{Detected Baltic inflow effects on oxygen and salinity}

A Major Baltic Inflow occurred in 2014 December (Mohrholz et al. 2015; Holtermann et al. 2017). More saline, oxygen rich, inflowing waters flowed slowly north along the bottom or along certain density layers. The MBI became visible in the Gotland Deep after Feb 2015 (Schmale et al. 2016). The first half of 2015 was still in the middle of the learning curve of our Argo operations, and therefore our profiles did not reach the near bottom waters of the Gotland Deep. Holtermann et al. (2017) measured the oxic situation in the Gotland Sea at the Gotland Deep Environmental Sampling Station 

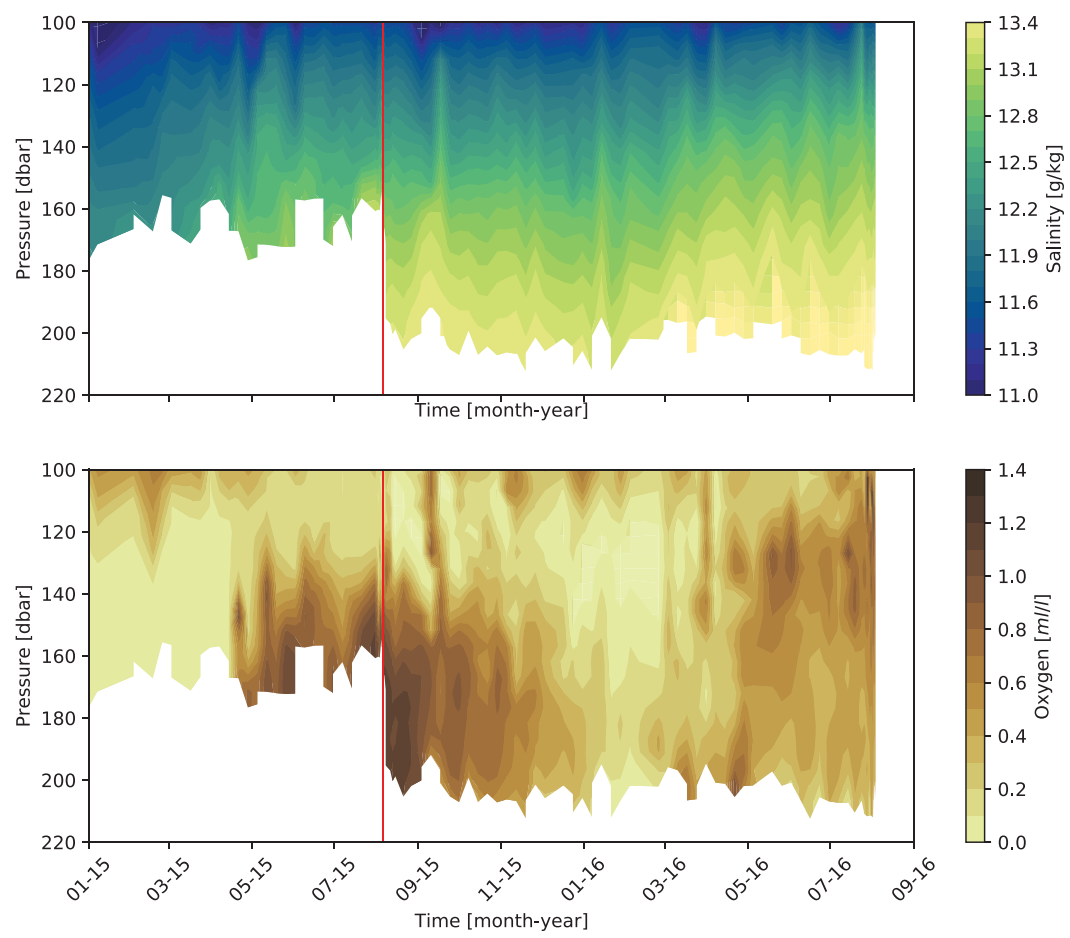

Figure 8. Salinity and oxygen measurements at the time when the $2014 \mathrm{MBI}$ reached the Gotland Deep. Red lines indicate float change.

(GODESS) in 2015 and noticed the intrusion of the MBIinduced water masses at the bottom-most layer (around $200 \mathrm{~m}$ ) in February 2015, with salinity and oxygen peaking at the end of April 2015.

In our Argo measurements, the changes in the deep water salinity and oxygen content became visible in mid-April 2015, as our profile depth at the time was around $170 \mathrm{~m}$ (Figure 8). The decay of the oxygen content in the intermediate deep waters is seen from September 2015 to March 2016. Another small rise in oxygen can be interpreted at the lowest depths from the data during March-May 2016.

The zero level of the Argo oxygen sensors differed by roughly $0.1 \mathrm{ml} / \mathrm{l}$. This is seen as a discontinuity in the time series at time points where the missions changed (Figure 9). The different calibration of the Argo floats was also visible in our analysis of the differences between the Argo float data and the ship data, with the differences between the missions the largest at the surface, roughly $0.5 \mathrm{ml} / \mathrm{l}$ (Table 2).

Figure 9 shows the change in salinity and oxygen at 120,150 and $180 \mathrm{~m}$ depths during the MBI. The salinity at $120 \mathrm{~m}$ depth increased roughly by $0.5 \mathrm{~g} / \mathrm{kg}$ from May 2014 to Feb 2015. Between February and March 2015 the salinity increased by approximately another $0.5 \mathrm{~g} / \mathrm{kg}$ and then stabilised to $12.3 \mathrm{~g} / \mathrm{kg}$. At the same time, oxygen conditions changed from near zero to $0.8 \mathrm{ml} / \mathrm{l}$ by April 2015 at $120 \mathrm{~m}$ depth.

At $150 \mathrm{~m}$ depth, the Argo measurements started in July 2014. Salinity has been rather constant there until March 2015. Between March and May 2015, the salinity at $150 \mathrm{~m}$ depth increased rapidly by 0.6 to 12.6 . The change in oxygen content was stronger at this depth, approximately $1 \mathrm{ml} / \mathrm{l}$ starting from April 2015. The peak oxygenation here was reached in July 2015 at nearly $1.1 \mathrm{ml} / \mathrm{l}$. In the beginning of 2016, the oxygen vanished from this depth. At $180 \mathrm{~m}$ depth, we mainly got measurements from the last float. Both the salinity and oxygen there followed the same trends as at $150 \mathrm{~m}$. These results are consistent with the results of Holtermann et al. (2017), considering that the float moves and that the lower-most layer is missing due to the diving depths, especially in earlier missions.

The Argo data from the Gotland Deep gives additional information on the MBIs and will give even more in the future when the routine operations have matured to catch a more complete column. The advantage is that if an MBI is identified by other means, we can increase the frequency of observations during the phase when the MBI reaches the Gotland Deep. 

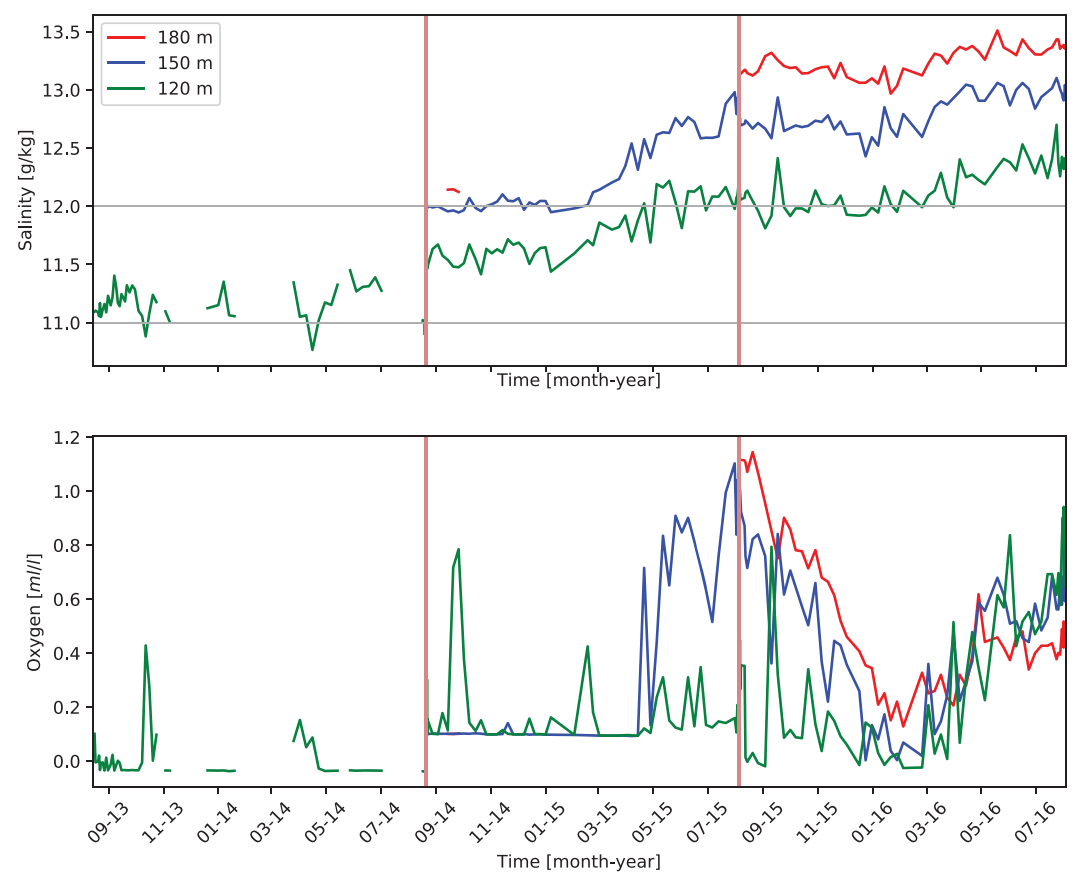

Figure 9. The salinity (above) and oxygen (below) as a function of time, from the Argo profiles, from 120, 150 and $180 \mathrm{~m}$ depths, where the float went deep enough. The change in salinity was slightly under $1 \mathrm{~g} / \mathrm{kg}$ from both 120 and $150 \mathrm{~m}$. The change was sharper at $150 \mathrm{~m}$. Oxygen in $120 \mathrm{~m}$ rose at highest to $1 \mathrm{ml} / \mathrm{l}$

\subsection{Wind-induced mixing in the surface layer}

The Argo dataset that we analyse here covers three springs and three autumns. As the floats measure approximately one profile a week, the time scale fits well for monitoring the general spring and autumn stratification cycle. We can see both the formation and the decay of the thermocline during three years from the dataset (Figure 2).

For example in 2013, the thermocline eroded faster than in 2014 and 2015 (Figure 10), which
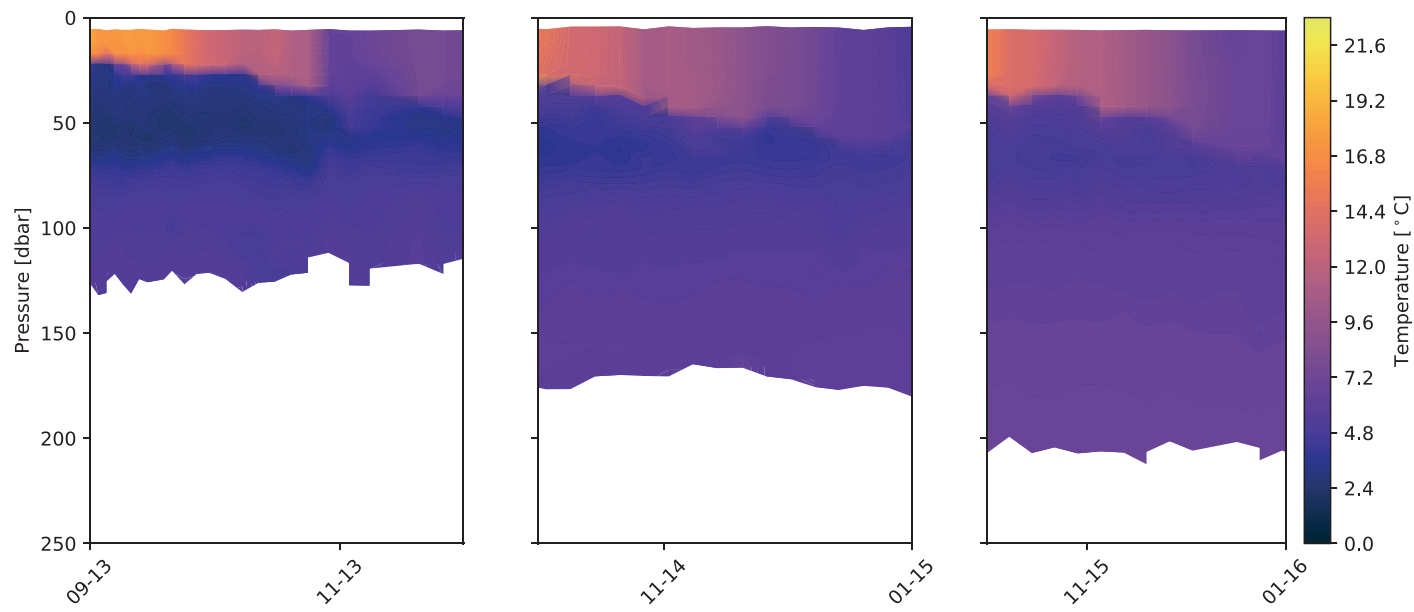

Figure 10. Autumn stratifications (2013, 2014 and 1015). At the far left (2013), the stratification dissolved quicker, due to hurricane 'Christian'. White colour indicates no data. 

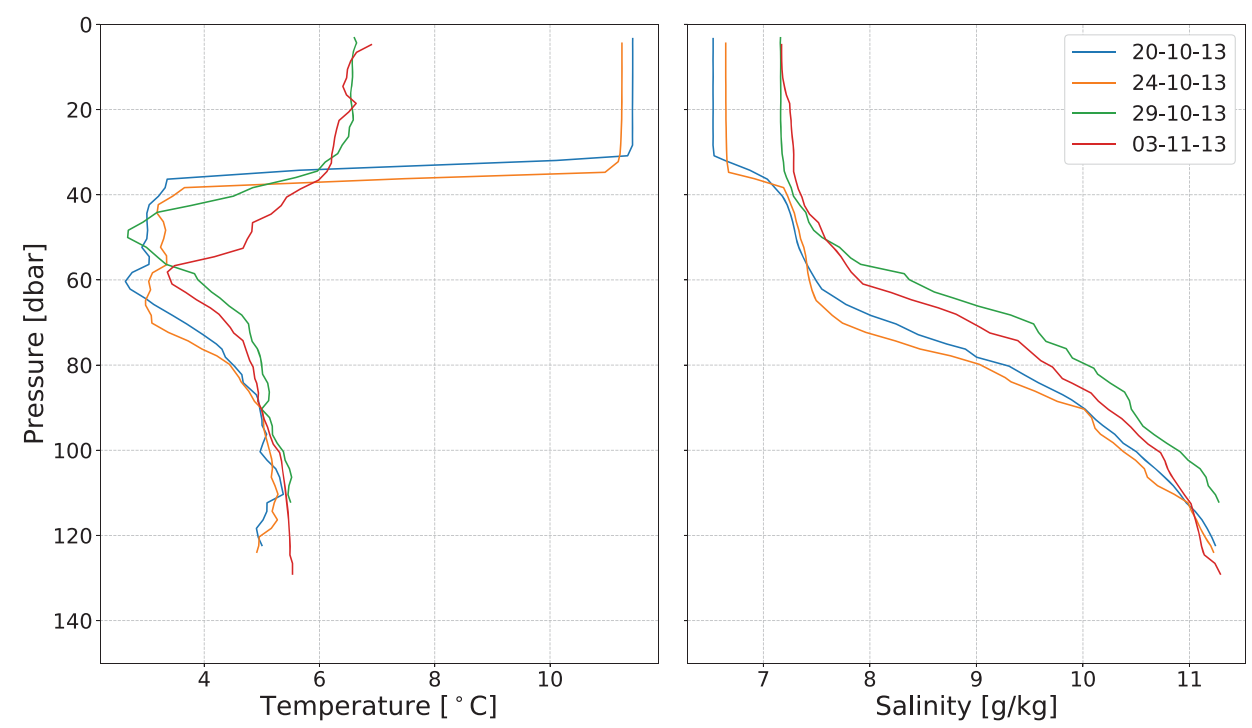

Figure 11. Argo profiles of temperature (left) and salinity (right) before and after the hurricane class storm 'Christian'.

was caused by the hurricane class storm 'Christian'. The storm crossed the Baltic Proper along its pathway from southern Scandinavia to southern Finland on October 28, 2013. In Denmark, the wind speeds reached the classification of violent storm and the maximum $10 \mathrm{~min}$ average speed measured was 39.5 $\mathrm{m} / \mathrm{s}$ at the Danish Meteorological Institute station number 615900, Røsnæs Fyr. From the 28th to the 29th of October, the wind speed was from 17.4 to $22.1 \mathrm{~m} / \mathrm{s}$ at the Östergarnsholm weather station, on the Gotland island in Sweden. This is the closest weather station to the Argo Baltic Proper locations. The maximum significant wave height in the northern Baltic Proper wave buoy during that event was $5.2 \mathrm{~m}$.

The strong thermocline eroded between two Argo profiles measured on the 24th and 29th of October (Figures 10 and 11), and denser water seems to have entered the area. The total salinity increase from the profiles before the storm to after the storm is explained by the float drifting nearly $40 \mathrm{~km}$ south, where the salinity is higher.

After the storm event, the thermocline started to reestablish until 20 November, after which it continued to deteriorate like in other autumns.

In 2014 and 2015, the thermocline erosion was not as dramatic as in 2013. These autumns were more calm, and the strong winds appeared later in the year when the stratification had already eroded due to the cooling of the water and milder weather events.

\section{Discussion}

Before the FMI's Argo missions in the Baltic Sea, the overall expectations of the possibility to operate them in marginal seas was rather pessimistic. The assumptions were that they most likely either get stuck on the bottom or drift to the shores pretty soon, before having time to do a proper measurement series. Luckily these expectations turned out to be too pessimistic, and now we are able to operate the Argo floats operationally in the Baltic Sea. Our operational Argo activity in the Gotland Deep has continued since the missions studied here with two floats (WMO numbers 6902024 and 6902027).

Operating an Argo float is relatively cheap in comparison to ship days: one Argo costs roughly as much as one ship day with a medium-sized, well-equipped research ship (National Research Council 2009; Argo project 2018, p. 68). The manpower needed during the Argo operations is small, and the work is done remotely. Ship-borne measurements and Argo operations are, however, very different in nature and will complement each other in the Baltic Sea: Research vessels can choose the exact time and location of the measurements and have a high depth resolution. A research vessel can also easily carry out a wide range of measurements on the same spot. The drawbacks are the limitations of hard weather and the cost of measuring. The ship's mission must also be planned far ahead, and changing weather can force the plans to change or be completely cancelled at worst. Argo floats are practically weather- 
independent and can measure frequently for long time periods. Their observation time step can be changed when needed, and the data is almost real-time. As Argo float profiles are usually recorded with constant intervals, it is likely to get profiles near before and after sudden events, occasionally even during them also in routine missions.

One drawback in our Argo data is the loss of the topmost metres of the surface layer. The algorithm that protects the SBE CTD sensor of our APEX floats shuts down the measurements well before the sensors reach the surface (Haavisto et al. 2018).

Argo floats are freely drifting platforms. In the Gotland Deep, the floats stayed most of the time within 30 $\mathrm{km}$ of the deployment point, occasionally drifting over $60 \mathrm{~km}$ away (Figure 4). As such, the whole dataset has profiles from a rather large area. The separation of temporal and spatial variations from the data needs to be considered carefully. To solve this problem, it is possible to select profiles according to the distance from a defined point for further time series analysis. This way, fewer profiles can be used in the analysis, but they are the ones which describe a similar area. This can be desired when comparing data with another, stationary system, or when the float circulates in an area with inhomogeneous properties to monitor the differences between these areas. It should also be kept in mind that Argo floats move with currents and can follow the movements of water masses. In contrast, shipborne CTD can be taken in the same spot regardless of the movements of water. With the float series, where new float replaces another, the jump in location and possibly also in calibration from one float to the another must be handled carefully (Figure 4).

The frequency of the Argo profiles makes it possible to monitor the evolution of the oxygen content for a longer period. The choice of the diving depth, however, is a compromise between the completeness of the profile down to the bottom and with the risk of losing the float in a bottom hit. Even with the cautious approach on the first missions described in this paper, the diving depths were enough to detect the major inflow event. With the improved understanding of how to operate Argo floats in the area, we will have even more complete data from the coming inflow events. As the oxygen measurements did have a higher bias than the CTD measurements, one should be careful when interpreting them.

Quality control of the Argo data needs further research when applied to marginal seas like the Baltic Sea. Consequent profiles can have large differences in salinities caused by a drifting of relatively small distances or strong salinity gradients. The well-established methods used in the large oceans can falsely flag these changes as measurement errors. In this work, we have presented a rudimentary method for detecting the faulty profiles, but further work is needed. Oxygen-sensor calibration needs further improvement. With the aid of close-by ship CTD measurements, it is possible to detect and account for the oxygen measurement bias. The procedures for doing this need to be further studied.

The tests in the Black Sea have found that the greater number of the Argo floats in the area had a larger impact on data assimilation quality than increasing the profiling frequency by the same amount (Grayek et al. 2015). The possibilities for increasing the number of Argo floats in the Gotland Deep are therefore studied. They are a very cost-efficient means of monitoring, and their use is agreed on within the IOC at least in the ocean. In the optimal case, several floats could be used after an MBI to more accurately measure the spread of the water masses.

The Argo floats applied in the Gotland Deep and the Baltic Sea in general can be used to study various cases other than the ones presented in this paper. In case of MBIs, the spreading of the incoming water is of interest, and then spatial variability is important. With enough Argo floats for longer time periods, the deep currents of the areas can also be researched (Roiha et al. 2018). Especially in the northern parts of the Baltic Sea, with proper ice avoidance, the possibility to measure under ice can provide valuable information that is hard to obtain in other ways. With a large enough fleet of Argo floats, modelling work on the Baltic Sea would also benefit through verification and assimilation of the Argo data. Occasional events, like Major Baltic inflows or storms, can be studied in more detail even with a regular weekly cycle of Argo floats. MBIs can be detected months before their effects arrive in the Gotland Deep. Because of this we can increase the Argo float measurement frequency in due time for the study of the coming MBIs at virtually no extra cost.

For further advancing the Argo measurements in the Baltic Sea, the controlling methods should be further developed and automated as the number of floats in operation increases. This requires developing algorithmic or artificial intelligence based control schemes and further study of the behaviour of the floats at given depths, areas and weather conditions. For northern parts, the application of ice-avoidance systems should be further advanced and studied with both algorithmic systems and physical solutions.

The topography plays an important role when planning further deployments of the Argo floats in marginal seas. Based on these experiences, the Gotland Deep is a suitable location, as it is relatively deep, and the deeper 
drift kept the float circulating around the area rather than moving it away. The size of the area confines the float to roughly a $40 \mathrm{~km}$ radius area, which is small enough to give meaningful local time series and large enough that weather fluctuations will not easily push it out of the area. Other basins with similar characteristics should be considered for further float deployments. Another larger area is operated in the Gulf of Bothnia (Haavisto et al. 2018; Roiha et al. 2018). Other interesting areas for deployment in the Baltic Sea include Bay of Bothnia, Gulf of Gdansk, Bornholm Basin (IOPAN 2018) and Western Gotland Basin. Poland is an observer at Euro-Argo, and the Institute of Oceanology of the Polish Academy of Sciences (IOPAS) in Sopot has begun to use Argo floats since November 2016 in the southern Baltic Sea including the Bornholm Basin. That data is also available at the Coriolis Argo data centre.

We study the options to keep the floats even closer to the bottom on certain occasions. Up to now the missions have followed a safety strategy with minimised risks of instrument losses and sensor faults. We have tried to guarantee the recovery of the floats by limiting the measurements in a way that the energy consumption is on the level where the float remains active until the next suitable research cruise for recovery. Webb Research specifications give 4 years and 150 ascents nominal operation capacity for the Apex float in the ocean with $2000 \mathrm{~m}$ profiling depth. With such specifications, about a one year mission time in the Gotland Deep is very feasible with one profile per week sampling.

Because the Argo floats are freely drifting devices, there is a concern about misinterpreting the data in respect to time and horizontal variations. There may be ways to decrease the danger of misinterpretations due to horizontal variations by using satellite data, though that data is surface data and Argo data is not, but mesoscale features may be identified from satellite images. The other way is to benefit from Alg@Line data, from where horizontal correlation scales can be estimated along the ship routes.

\section{Conclusions}

FMI has experimented with Argo floats in the Baltic Sea since 2011, first in the Bothnian Sea and then extended to the Gotland Deep. Operating the floats has matured to a level where we can state that Argo monitoring of the Baltic Sea is now an operative reality. The data goes in near real-time to the global Argo data centre and is available on the Internet. Finland is a member of Euro-Argo and has Argo floats in the North Atlantic, too. This membership should guarantee continuity of this operative monitoring and gives possibilities to develop the Baltic Sea monitoring. However, when operating in the area, the various national jurisdictions should be considered, especially as the Intergovernmental Oceanographic Commission's Executive Council adopted in June 2018 (IOC 2018) a decision that expands the standard bioArgo float sensors to include oxygen, $\mathrm{pH}$, nitrate, chlorophyll, backscatter and irradiance.

Operating Argo floats, which were originally planned for deep ocean use, in a shallow marginal sea is demonstrated to be feasible, cost-efficient and useful in the varying conditions in the Baltic Sea. It complements measurements done by other means like research ships, moored stations and gliders. The latter ones are coming to the Baltic Sea after Argo floats, as both Estonia and Finland are now using shallow water gliders there, too.

The Argo floats supplement well the data gathered from other instruments. The investment is relatively low cost. The floats are recoverable during regular monitoring cruises; they are reusable after maintenance; they are practically weather-independent; and the data comes in near real-time within an international data exchange system and is freely available. The telemetry costs are feasible and 'piloting' costs are rather low, too. Argo floats are meant to be autonomous without the need for piloting. However, in the Baltic Sea some 'piloting' guarantees they keep running in the desired areas. This means that their location must be monitored on a weekly basis, and there needs to be established practices to give them new instructions if needed. Since the floats studied here, we have constantly maintained at least one active Argo float in the Gotland Deep and various numbers of active Argo floats in the Bothnian Sea.

We have shown that the resolution of the measurements is capable of systematically detecting changes in the dynamics of the sea on the scale of days, for example the thermocline erosion in autumn 2013 during the hurricane class storm.

The effects of the late $2014 \mathrm{MBI}$ was also detected in the Argo data. The first signs were seen in the deepest observations.

Argo floats detected the first signs of the late 2014 MBI around April, 2015, with increasing salinity and oxygen levels at the depths of $150 \mathrm{~m}$. Around the same time, it was visible on CTD measurements that reached the bottom (235 m) (Neumann et al. 2017).

\section{Acknowledgments}

ICES Dataset on Ocean Hydrography. The International Council for the Exploration of the Sea, Copenhagen. 2014 Argo data was collected and made freely available by the International Argo Program and the national programs that contribute to it. (http://www.argo.ucsd.edu, http://argo. 
jcommops.org). The Argo Program is part of the Global Ocean Observing System.

\section{Disclosure statement}

No potential conflict of interest was reported by the authors.

\section{ORCID}

Simo Siiriä (i) http://orcid.org/0000-0001-8261-8370

Petra Roiha (1) http://orcid.org/0000-0001-9585-206X

Laura Tuomi (1D) http://orcid.org/0000-0003-2471-6815

Pekka Alenius (D) http://orcid.org/0000-0002-8033-4830

\section{References}

Aanderaa Data Instruments AS. 2001. Oxygen optode. [accessed 2018-03-20]. https://www.aanderaa.com/media/ pdfs/oxygen-optode-4330-4330f.pdf.

Argo project. 2018. Argo, part of the integrated ocean observation strategy. [accessed 2018-06-06]. http://www.argo. ucsd.edu/FAQ.html\#cost.

IOPAN. 2018. Baltic Argo floats deployed by IO PAN. https:// www.iopan.pl/hydrodynamics/po/Argo/argo.html.

Carval T, Keeley R, Takatsuki Y, Yoshida T, Loch S, Schmid C, Goldsmith R, Wong A, McCreadie R, Thresher A, et al. 2017. Argo user's manual v3.2.

Coriolis. 2001. Coriolis data portal. [accessed 2017 Sep 7]. http://www.coriolis.eu.org/.

Dietze H, Löptien U. 2016. Effects of surface current/wind interaction in an eddy-rich general ocean circulation simulation of the Baltic Sea. Ocean Sci. 12:977-986. http:// oceanrep.geomar.de/31634/.

Grayek S, Stanev EV, Schulz-Stellenfleth J. 2015. Assessment of the Black Sea observing system. A focus on 2005-2012 Argo campaigns. Ocean Dyn. 65(12):1665-1684. https://doi.org/ 10.1007/s10236-015-0889-8.

Haavisto N, Tuomi L, Roiha P, Siiriä SM, Alenius P, Purokoski T. 2018. Argo floats as a novel part of the monitoring the hydrography of the Bothnian Sea. Front Mar Sci. 5:324. https://www. frontiersin.org/article/10.3389/fmars.2018.00324.

Holtermann PL, Prien R, Naumann M, Mohrholz V, Umlauf L. 2017. Deepwater dynamics and mixing processes during a major inflow event in the central Baltic Sea. J Geophys Res Oceans. 122(8):6648-6667. http://dx.doi.org/10.1002/ 2017JC013050.

National Research Council. 2009. Science at sea: meeting future oceanographic goals with a robust academic research fleet. Washington (DC): The National Academies Press. https://www.nap.edu/catalog/12775/science-at-seameeting-future-oceanographic-goals-with-a-robust.

IOC. 2018. Intergovernmental oceanographic commission: fifty-first session of the executive council, draft summary report, Part 2. http://ioc-unesco.org.

IOC, SCOR, IAPSO. 2010. The international thermodynamic equation of seawater - 2010: calculation and use of thermodynamic properties. UNESCO. (Intergovernmental Oceanographic Commission, Manuals and Guides; 56).

Leppäranta M, Myrberg K. 2009. Physical oceanography of the Baltic Sea. Berlin, Heidelberg: Springer-Verlag.
Le Traon PY. 2013. From satellite altimetry to Argo and operational oceanography: three revolutions in oceanography. Ocean Sci. 9:901-915.

HELCOM. 2017. Manual for marine monitoring in the COMBINE Programme of HELCOM. http://www.helcom. fi/action-areas/monitoring-and-assessment/manuals-andguidelines/combine-manual/.

Matthäus W. 2006. The history of investigation of salt water inflows into the Baltic Sea-from the early beginning to recent results. Rostock-Warnemünde: Inst. für Ostseeforschung.

Meier HEM, Feistel R, Piechura J, Arneborg L, Burchard H, Kuzmina N, Mohrholz V, Nohr C, Paka VT, Sellschopp J, et al. 2006. Ventilation of the Baltic Sea deep water: a brief review of present knowledge from observations and models. Oceanologia. 48(S):133-164.

Mohrholz V, Naumann M, Nausch G, Krüger S, Gräwe U. 2015. Fresh oxygen for the Baltic Sea - an exceptional saline inflow after a decade of stagnation. J Mar Syst. 148:152-166. http://dx.doi.org/10.1016/j.jmarsys.2015.03.005.

Neumann T, Radtke H, Seifert T. 2017. On the importance of major Baltic inflows for oxygenation of the central Baltic Sea. J Geophys Res Oceans. 122(2):1090-1101. http://dx. doi.org/10.1002/2016JC012525.

Prien RD, Schulz-Bull DE. 2016. Technical note: godess - a profiling mooring in the Gotland Basin. Ocean Sci. 12 (4):899-907. https://www.ocean-sci.net/12/899/2016/.

Purokoski T, Aro E, Nummelin A. 2013. First long-term deployment of Argo float in Baltic Sea. Sea Technol. 54:41-44.

Riser SC, Freeland HJ, Roemmich D, Wijffels S, Troisi A, Belbéoch M, Gilbert D, Xu J, Pouliquen S, Thresher A, et al. 2016. Fifteen years of ocean observations with the global Argo array. Nat Clim Chang. 6(2):145.

Roiha P, Siiriä SM, Haavisto N, Alenius P, Westerlund A, Purokoski T. 2018. Estimating currents from Argo trajectories in the Bothnian Sea, Baltic Sea. Front Mar Sci. 5:308. https://www.frontiersin.org/article/10.3389/fmars. 2018.00308.

Schmale O, Krause S, Holtermann P, Guerra NCP, Umlauf L. 2016. Dense bottom gravity currents and their impact on pelagic methanotrophy at oxic/anoxic transition zones. Geophys Res Lett. 43(10):5225-5232. https://agupubs. onlinelibrary.wiley.com/doi/abs/10.1002/2016GL069032.

Seifert T, Tauber F, Kayser B. 2001. A high resolution spherical grid topography of the Baltic Sea - 2nd ed. Baltic Sea Science Congress, Stockholm Nov 25-29, Poster \#147. www.io-warnemuende.de/iowtopo.

Tuomi L, Myrberg K, Lehmann A. 2012. The performance of the parameterisations of vertical turbulence in the $3 \mathrm{D}$ modelling of hydrodynamics in the Baltic Sea. Cont Shelf Res. 50:64-79.

Westerlund A, Tuomi L. 2016. Vertical temperature dynamics in the northern Baltic Sea based on 3D modelling and data from shallow-water Argo floats. J Mar Syst. 158:34-44. http://www.sciencedirect.com/science/article/pii/ S0924796316000191.

Winterhalter B, Flodén T, Ignatius H, Axberg S, Niemistö L. 1981. Chapter 1. Geology of the Baltic Sea. In: Voipio A, editor. The Baltic Sea. Elsevier; p. 1-121. (Elsevier oceanography series; vol. 30). http://www.sciencedirect.com/science/ article/pii/S0422989408701387. 



\section{Publication II}

Noora Haavisto, Laura Tuomi, Petra Roiha, Simo-Matti Siiriä, Pekka Alenius and Tero Purokoski. Argo floats as a novel part of the monitoring the hydrography of the Bothnian Sea. Frontiers in Marine Science, 5:324, doi:10.3389/fmars.2018.00324, 2018. 



\title{
Argo Floats as a Novel Part of the Monitoring the Hydrography of the Bothnian Sea
}

\author{
Noora Haavisto ${ }^{1 \dagger}$, Laura Tuomi ${ }^{1 *}$, Petra Roiha ${ }^{1}$, Simo-Matti Siiriä ${ }^{1}$, Pekka Alenius $^{1}$ and \\ Tero Purokoski
}

${ }^{1}$ Department of Marine Research, Finnish Meteorological Institute, Helsinki, Finland, ${ }^{2}$ Department of Observation Services, Finnish Meteorological Institute, Helsinki, Finland

OPEN ACCESS

Edited by:

Pengfei Xue,

Michigan Technological University,

United States

Reviewed by:

Begoña Pérez-Gómez,

Puertos del Estado, Madrid, Spain

*Correspondence:

Laura Tuom

laura.tuomi@fmi.fi

tPresent Address:

Noora Haavisto,

Tvärminne Zoological Station, Faculty of Biological and Environmental Sciences, University of Helsinki, Helsinki, Finland

Specialty section This article was submitted to Coastal Ocean Processes, a section of the journa

Frontiers in Marine Science

Received: 29 March 2018 Accepted: 23 August 2018 Published: 18 September 2018

Citation:

Haavisto N, Tuomi L, Roiha $P$, Siiriä S-M, Alenius $P$ and Purokoski T (2018) Argo Floats as a Novel Part of the Monitoring the Hydrography of the Bothnian Sea. Front. Mar. Sci. 5:324. doi: 10.3389/fmars.2018.00324
We made an assessment of the hydrography in the Bothnian Sea based on data collected by the Argo floats during the first 6 years of operation in the Bothnian Sea (2012-2017). We evaluated the added value of Argo data related to the pre-existing monitoring data. The optimal usage and profiling frequency of Argo floats was also evaluated and the horizontal and vertical coverage of the profiles were assessed. For now we lose $4 \mathrm{~m}$ of data from the surface due to sensor design and some meters from the bottom because of the low resolution of available bathymetry data that is used to avoid bottom collisions. Mean monthly temperature and salinity close to surface and below halocline from the float data were within the boundaries given in literature, although some variation was lost due to scarcity of winter profiles. The temporal coverage of the Argo data is much better than that of ship monitoring, but some spatial variability is lost since the floats are confined in the over $100 \mathrm{~m}$ deep area of the Bothnian Sea. The possibility to adjust the float profiling frequency according to weather forecasts was successfully demonstrated and found a feasible way to get measurements from storms and other short term phenomena unreachable with research vessels. First 6 years of operation have shown that Argo floats can be successfully operated in the challenging conditions of the Bothnian Sea and they are shown to be an excellent addition to the monitoring network there. With multiple floats spread in the basin we can increase our general knowledge of the hydrographic conditions and occasionally get interesting data related to intrusions and mixing during high wind events and other synoptic scale events.

\section{Keywords: Bothnian Sea, hydrography, Argo floats, Baltic Sea, monitoring, instrument}

\section{INTRODUCTION}

The physical properties of the water masses and the changes in them have been monitored in the Bothnian Sea since the late 19th century (Pettersson and Ekman, 1897). Ocean observation techniques have evolved during the past century from manual shipborne water sampling to ever more precise and autonomous measurements with modern electronic devices. In the last 40 years CTD (Conductivity-Temperature-Depth) profiling from research vessels has been the most common practice of standard monitoring. Moored instruments at surface, at certain depths and profiling moorings are also used along with remote sensing. Various remotely operable platforms for measuring hydrography, for example Argo floats, gliders and wave gliders, have become widely used. The most commonly used is the Argo float. There are close to 4,000 floats spread in the 
oceans worldwide as a part of the International Argo Program, but they have seen little use in shallow coastal seas. For example Grayek et al. (2015) and Kassis et al. (2015) have deployed floats in relatively small basins in the Cretan Sea and the Black Sea, but these areas are much deeper than the Bothnian Sea.

Monitoring of the sea is essential for gaining knowledge of the past and present state and changes of the water column, and the effect of climate change on our sea areas. At present the Finnish monitoring of the Bothnian Sea hydrography in the open sea areas is the responsibility of the Finnish Meteorological Institute and the monitoring is done in co-operation with the Finnish Environment Institute three times a year as a part of the Helsinki Comission (HELCOM) monitoring programme COMBINE (HELCOM, 2014).

Although monitoring aims at providing long time series from fixed locations to evaluate the long-term changes in the state of the Bothnian Sea, for many applications measurements with higher temporal resolution that reflect the course of seasonal cycles of temperature and salinity are needed. Even higher temporal resolution, with observation interval being a day or in some cases even less allows us to record phenomena happening in short time scales, and helps to put the sparse ship monitoring data into context in relation to the seasonal cycles. Improving modeled forecasts by data assimilation and validation also require frequent in-situ data. Argo floats provide a relatively cost efficient method for measuring with high temporal resolution in the open sea.

The Finnish Meteorological Institute (FMI) first tested an Argo float in the Baltic Sea in 2011 and has operated them in the Bothnian Sea and the Gotland deep since 2012 as a part of Euro-Argo ERIC. We now have an operational float in the Bothnian Bay as well. The characteristics of the Baltic Sea present challenges to float operations, but the floats have been found to function adequately there. Their data has already been used for model validation (Westerlund and Tuomi, 2016) and the deep water circulation in the Bothnian Sea was assessed from their drift speed by Roiha et al. (2018).

In this study we assess the hydrography of the Bothnian Sea based on the first 6 years of Argo data. The added value of Argo floats to the existing monitoring network, that in the open sea consists only of ship observations from regular monitoring cruises, is evaluated and different options for Argo float use in the Bothnian Sea are compared. Finally we make suggestions for further development of the monitoring network in the Bothnian Sea.

\subsection{The Bothnian Sea}

The Bothnian Sea is a shallow semi-enclosed sub-basin of the Baltic Sea. It is connected to the Baltic Sea Proper only through narrow straits through the Åland Sea (the Southern Quark) and the shallow Archipelago Sea connecting it to the northern Baltic Sea Proper (Figure 1). The water in the basin, as in the entire Baltic Sea, is brackish due to large river runoff and limited inflow of saline water from the Baltic Proper. The surface area of the Bothnian Sea is $64,886 \mathrm{~km}^{2}$ and the mean depth is $66 \mathrm{~m}$ (Fonselius, 1996), with an over $100 \mathrm{~m}$ deep area reaching from the sill to Alland Sea along the Finnish coast to NorthNortheast (referred to as the Bothnian Sea deep in this work), and shallower banks with numerous shoals on the Swedish side called Finngrunden banks. The deepest point in the Bothnian Sea is the Ulvö deep next to the northern Swedish coast.

A weak halocline on average at $50-60 \mathrm{~m}$ separates the deep water from the mixed layer in the Bothnian Sea. The mixed layer overturns in the spring and autumn, and in the summer a thermocline of $15 \mathrm{~m}$ depth on average forms. The Bothnian Sea is at least partially covered by sea ice every winter. Fresh water runoff from land dominates the mixed layer, while the deep water is replenished by inflow of saline water from above the halocline in the northern Baltic Sea Proper (Håkansson et al., 1996; Hietala et al., 2007). There is a N-S gradient in salinity in the Bothnian Sea, with more saline water in the South and along the Finnish coast, than in the North and down the Swedish coast. The surface salinity ranges from 4.8 to $6.0 \mathrm{~g} \mathrm{~kg}^{-1}$ and the bottom salinity is between 6.4 and $7.2 \mathrm{~g} \mathrm{~kg}^{-1}$ (Bock, 1971). The average temperature at the surface reaches $16^{\circ} \mathrm{C}$ in the summer, and the bottom temperature varies between 1.5 and $4.5^{\circ} \mathrm{C}$ (Haapala and Alenius, 1994).

\subsection{Argo Floats in the Bothnian Sea}

Argo floats are designed for open ocean, where proximity to shoreline or bottom depth do not have to be considered. The specific features of the Bothnian Sea, such as seasonal ice cover, relatively small size of the basin and low salinity, present challenges for the operation of floats. There are risks of the float touching the bottom and getting stuck, drifting to even shallower waters and on shore, and hitting seasonal ice cover.

Seasonal differences in the Bothnian Sea stratification present a challenge for the float diving. A large change in the float density may be needed to penetrate the seasonal thermocline and the halocline, but in spring and autumn only a small float density change may result in sinking straight to the bottom in the overturned water column. To address this problem Purokoski et al. (2013) modified APEX float's diving algorithm to respond faster to pressure change. This method worked, but it increased the energy consumption of the float and therefore was not applied in further missions to increase the mission duration.

To prevent collision with seasonal ice cover, the float can be commanded to cut the ascent at a certain threshold of temperature. So far $0-1{ }^{\circ} \mathrm{C}$ has been used depending on the conditions, but more ice winters are needed to find an optimal value. If the float does not reach the surface it saves the data and sends it when the GPS connection has been established next time. The ice avoidance limits data coverage of the upper water column during ice season.

When operating in small basins, it is beneficial to have some control on the drifting of the floats, so that they do not drift to shallow coastal waters. It was found that driving the floats to the vicinity of the bottom between the measurement cycles worked well, and also in some cases lead to nearly stationary floats. An advantage with operating so close to shore is that the floats can be retrieved for maintenance after each mission and redeployed. On the other hand the floats in the Bothnian Sea require in general much more operator time than the usual open ocean floats. 


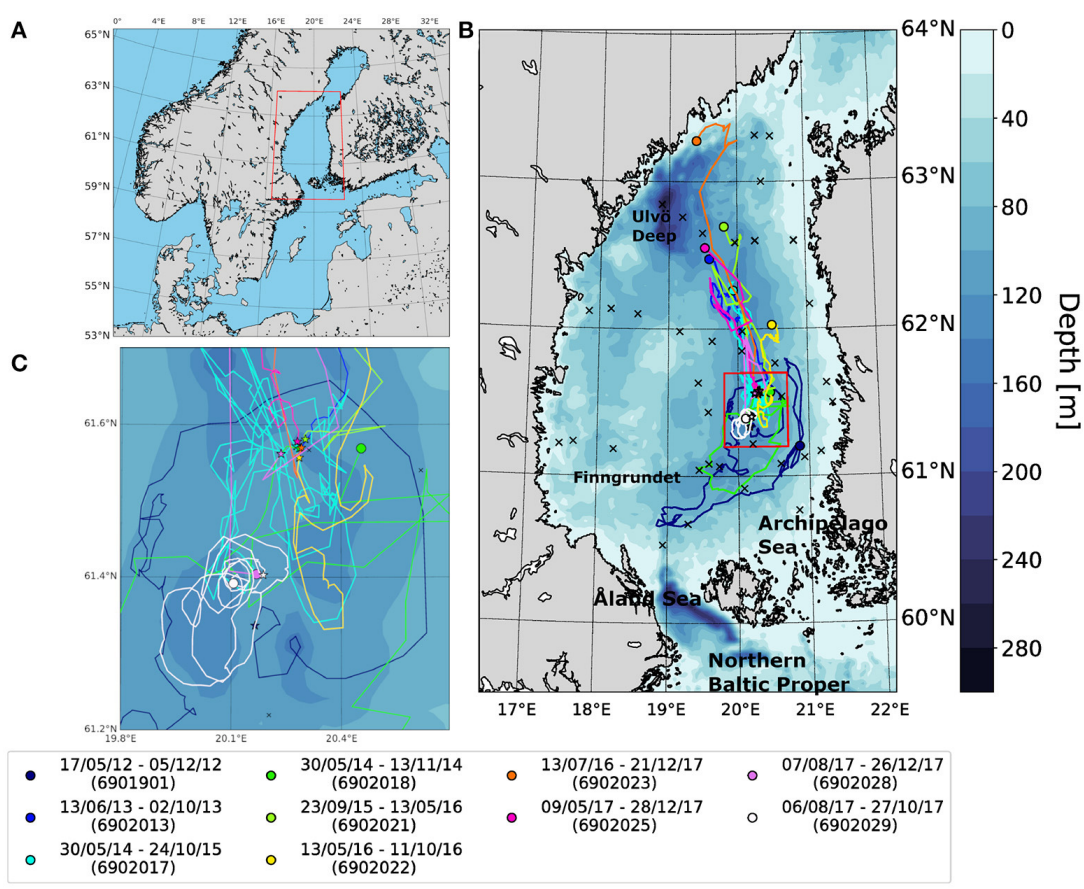

FIGURE 1 | (A) Bothnian Sea location in the Baltic Sea (B), Argo float drift routes in the Bothnian Sea, and (C) a zoomed in map of the deployment area. The colors indicate separate deployments, and the stars and circles represent the deployment point ant the point of float retrieval or of latest profile, respectively. The black x:S show locations of CTD-profiles measured in the Bothnian Sea deep during 2012-2017. The bathymetry data is from Seifert et al. (2001).

\section{OBSERVATIONS AND METHODS}

\subsection{Argo Data}

The Argo profiles used in the analysis of this paper were collected in the Bothnian Sea in 2012 -2017. The data is from 10 different deployments, six of which were done with reused floats. In Argo system the floats are identified with unique WMO numbers that are related to the deployments rather than the physical float themselves. The floats used were 2,000 m APEX floats by Teledyne Webb Research. The details of the used floats and their measured parameters are listed in Table 1. For detailed information of the sensors and Argo float structure and operation see Teledyne Webb Research, Inc. (2013). The data is freely available at Argo (2000) ${ }^{1}$.

Altogether 1,280 float cycles were recorded over the 6 years period, of which 1,083 resulted in a profile of the water column. Here unsuccessful cycles were defined as profiles with only up to four measurement points in the entire water column. The percentage of failed profiles varies between deployments (Table 2). Most of these failed profiles were due to float being temporarily stuck in the bottom or the float not diving properly

\footnotetext{
${ }^{1}$ http://www.coriolis.eu.org/Data-Products/Data-Delivery/Argo-floats-byWMO-number
}

TABLE 1 | Details of the Argo floats used in the Bothnian Sea 2012-2017.

\begin{tabular}{|c|c|c|c|c|}
\hline & APE1 & APE2 & HAPE1 & BAPE2 \\
\hline Model & \multicolumn{4}{|c|}{ APEX-APF9I } \\
\hline $\begin{array}{l}\text { Communications } \\
\text { and positioning }\end{array}$ & \multicolumn{4}{|c|}{ Two-way Iridium Short Burst Data (SBD), GPS } \\
\hline $\begin{array}{l}\text { Measured } \\
\text { parameters }\end{array}$ & \multicolumn{2}{|c|}{$\begin{array}{c}\text { Pressure, temperature, } \\
\text { salinity }\end{array}$} & + oxygen & $\begin{array}{l}\text { + fluorecence, } \\
\text { turbidity }\end{array}$ \\
\hline Sensors & \multicolumn{2}{|c|}{ Sea-Bird SBE-41CP } & $\begin{array}{l}+ \text { Aanderaa } \\
\text { Optode } 4330\end{array}$ & $\begin{array}{l}+ \text { WET Labs } \\
\text { FLbb }\end{array}$ \\
\hline \multirow{2}{*}{$\begin{array}{ll}\text { Additional lce avoidance } & \text { algorithm } \\
\text { spesifications } & \end{array}$} & $x$ & & $x$ & $x$ \\
\hline & \multicolumn{2}{|c|}{$\begin{array}{l}\text { Modified pressure } \\
\text { detection algorithm } \\
\text { by FMl and Aalto } \\
\text { University }\end{array}$} & & \\
\hline
\end{tabular}

Extended from Roiha et al. (2018).

from the surface in the first place. The sampling resolution was $2 \mathrm{dbar}$ except for profiles less than $50 \mathrm{~m}$ deep, for which the sampling resolution is $5 \mathrm{dbar}$ due to a software bug in the floats. In this paper "delayed mode" data was used whenever available, and only data with a quality flag 1 or 2 were used (see Argo Data Management Team, 2017 for details). Missing 
TABLE 2 | Argo float deployments in the Bothnian Sea in 2012-2017.

\begin{tabular}{|c|c|c|c|c|c|c|c|}
\hline WMO & Float & Cycles & $\begin{array}{l}\text { Recorded } \\
\text { profiles }\end{array}$ & $\begin{array}{c}\text { Mean cycle } \\
\text { length [d] }\end{array}$ & $\begin{array}{l}\text { Mean profile } \\
\text { depth [dbar] }\end{array}$ & $\begin{array}{l}\text { Bottom } \\
\text { hits [\%] }\end{array}$ & Mission timespan \\
\hline 6901901 & APE1 & 314 & 247 & 1 & 59 & 0 & $17.05 .2012-05.12 .2012$ \\
\hline 6902013 & APE2 & 119 & 119 & 1 & 77 & 0 & 13.06.2013-02.10.2013 \\
\hline 6902017 & APE1 & 176 & 173 & 2 & 115 & 13 & $30.05 .2014-24.10 .2015$ \\
\hline 6902018 & BAPE2 & 58 & 50 & 4 & 93 & 30 & $30.05 .2014-13.11 .2014$ \\
\hline 6902022 & APE2 & 217 & 215 & 0.5 & 101 & 10 & 13.05.2016-11.10.2016 \\
\hline 6902023 & APE1 & 103 & 40 & 7 & 89 & 69 & 13.07.2016-31.12.2017 \\
\hline 6902025 & HAPE1 & 49 & 47 & 7 & 108 & 19 & $09.05 .2017-31.12 .2017$ \\
\hline 6902028 & BAPE2 & 31 & 20 & 7 & 111 & 38 & $07.08 .2017-31.12 .2017$ \\
\hline 6902029 & APE2 & 160 & 159 & 0.5 & 118 & - & $06.08 .2017-27.10 .2017$ \\
\hline
\end{tabular}

Bolded missions were ongoing at the end of the year 2017. Bottom hit here means that the float had a bottom contact some time during a measurement cycle. The table is modified and extended from Roiha et al. (2018).
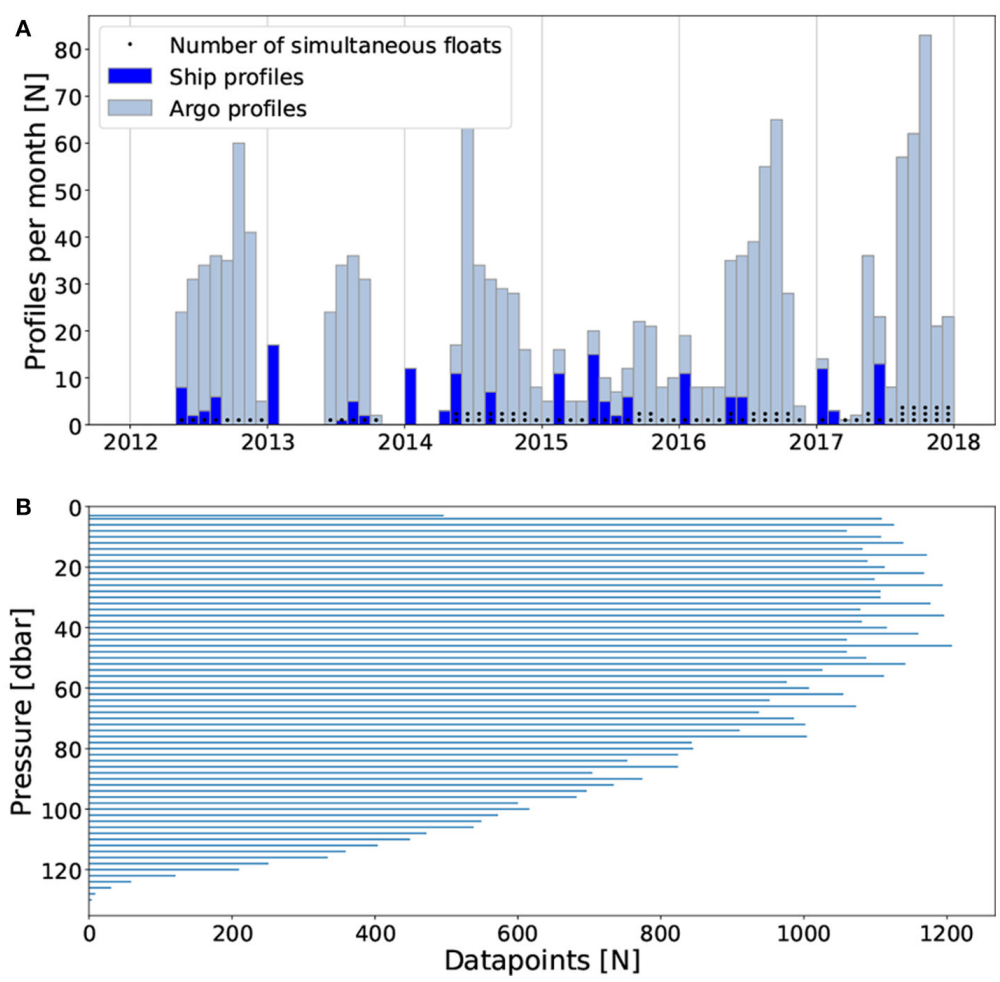

FIGURE 2 | (A) Number of measured Argo profiles (gray) and CTD profiles (blue) per month in the Bothnian Sea for 2012-2017. The black dots represent the amount of simultaneous floats each month. (B) Number of measurements per depth with a 2 dbar resolution with the Argo floats during $2012-2017$.

latitude and longitude information for cycles that didn't reach the surface were interpolated for the purpose of density and salinity calculations.

Most of the Argo profiles were measured during the ice free season, and since 2014 continuous measurements have been made with at least one float over wintertime, although there are some short gaps in 2016-2017 where the mission 6902023 didn't provide profiles due to it being temporarily stuck in the bottom (Figure 2A). The mean deepest measurement point per profile for all missions was at $94 \mathrm{dbar}$, and the mean deepest 
measurement point per profile of each mission varied from 59 (6901901) to $118 \mathrm{dbar}$ (6902029) (Table 2) depending on the drifting area and target pressure relative to bathymetry. The deepest pressure measured at was $130 \mathrm{dbar}$ (26.10.2017, 6902029).

All the floats were deployed inside an area of $615 \mathrm{~km}^{2}$ with maximum $28 \mathrm{~km}$ between the deployment points (Figure 1). The floats mostly stayed confined in the Bothnian Sea deep basin. Two floats had a cyclonic drift path along isobaths in the southern Bothnian Sea (missions 6901901 and 6902018), one was almost stationary with maximum distance between profiles being $24 \mathrm{~km}$ (6902029), and the rest followed the deep toward NorthNortheast. There were three simultaneous deployments in the autumn of 2017 (6902025, 6902028, and 6902029) with 6902028 and 6902029 close to each other and 6902025 more to the North (locations of the floats shown in Figure 1). A fourth float, mission 6902023, was also active during the same period, but it was stuck in the bottom from May to December 2017.

During the first two missions (6901901 and 6902013) the park pressure of the floats was kept at around $80 \mathrm{dbar}$ to avoid bottom contacts. Due to this, approximately a $30 \mathrm{~m}$ deep layer above the bottom was not observed. For the rest of the missions the floats were kept closer to bottom, on average $10 \mathrm{~m}$ away, for better steering. This also resulted in more frequent bottom contacts (Table 2). Due to the high profiling frequency for mission 6902029 it was difficult to estimate the amount of bottom contacts since it spent such a short time at the park pressure between profiles. On average $4 \mathrm{~m}$ from surface was not measured due to CTD sensor design. In this work "near surface" refers to the shallowest available data point in the Argo profiles. Gridded bathymetry data from Seifert et al. $(2001)^{2}$ was used to estimate the depth at profile locations.

The ice avoidance algorithm preventing the floats from colliding with sea ice got it's first operational test during winter 2016-2017, when float 6902023 drifted under sea ice from February to April. The partial profiles it measured during that time show that the algorithm did detect the cold water mass and cut the float ascent as planned.

\subsection{CTD Data}

CTD data used here for comparison was measured on the Finnish research vessel RV Aranda in the Bothnian Sea 1998-2017. A Seabird CTD probe was installed on Aranda in 1997 so this 20 year period gives us a consistent data set to compare with. Since Finland is responsible for monitoring of the Bothnian Sea together with Sweden, and the deep area of the basin is mostly located in Finnish waters, most of the deep CTD profiles from the Bothnian Sea are included in the data set and give a comprehensive picture of the availability of CTD profiles in the area. The average number of CTD profiles per month was 3 for 1998-2017 and 2 for 2012-2017, although it greatly varies depending on monitoring and research campaign timing with usually around 4 months in a year having any measurements (Figure 2A). The locations of the profiles in 2012-2017 are shown in Figure 1.

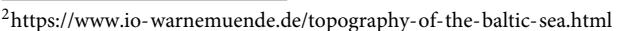

\subsection{Variables and Units}

Density and absolute salinity for the Argo and CTD profiles were calculated using the Python implementation ${ }^{3}$ of the Thermodynamic Equation Of Seawater- 2010 (TEOS-10) (IOC et al., 2010). All salinity data presented in this work are in absolute salinity, but the values from literature are presented as they were in the original work, which was usually practical salinity. The difference of absolute salinity and practical salinity is approximately 0.1 with absolute salinity being higher, and this is taken into account in the comparisons. Temperature shown is the in situ temperature, except for T-S diagrams, for which potential temperature calculated according to TEOS-10 was applied.

Since the amount of Argo and CTD profiles greatly varies between seasons and the same month of different years, the monthly mean values shown were calculated by first averaging over each month with data (or using the profile as is for months with only one profile) and then taking the mean over the years for each month. The monthly means were considered valid up to 100 dbar depth, below which there were only scattered datapoints (Figure 2B). Winter means were calculated for 2014-2017 due to lack of winter profiles before 2014, while other seasons also include years 2012 and 2013. Halocline and thermocline depths were calculated as the depth of maximum gradient of salinity and temperature. Seasonal halocline was excluded from the analysis by using measurements only under thermocline when it existed.

\section{RESULTS}

\subsection{Hydrography Based on Argo Data}

Six summers and 3 year-round (2014-2017) cycles of temperature and salinity in the water column were measured during 2012-2017. Near surface temperature varied from $0.1^{\circ} \mathrm{C}$ (10.3.2017, float 6902023) to $22.7^{\circ} \mathrm{C}$ (28.7.2014, float 6902017), and the seasonal variation reached to almost $100 \mathrm{dbar}$ depth during winter 2014-2015 (Figure 3). In 2014, the near surface temperature was overall much higher than in the other years, up to $3^{\circ} \mathrm{C}$ higher than in the second warmest summer 2016, and up to $6^{\circ} \mathrm{C}$ warmer than the average of the warmest month, August (Figure 4A). Monthly mean temperature (2012-2017 average for ice-free season and 2014-2017 average for winter months) close to surface varied between 1.7 and $16.8^{\circ} \mathrm{C}$ with highest temperatures in August and lowest in March before the spring overturning, and the mean temperature at $100 \mathrm{dbar}$ was between 3.6 and $4.5^{\circ} \mathrm{C}$. The depth of $100 \mathrm{dbar}$ was chosen to represent deep water, since it was the deepest HELCOM standard depth with measurements for every month of the year, and it was always below the calculated halocline depth. Thermocline development varied between years, starting in May with strongest stratification $\left(-2.0^{\circ} \mathrm{C} / \mathrm{m}\right)$ in August, after which the thermocline started to decay. The mean depth of the thermocline in August varied between $13 \mathrm{dbar}$ (2014) and $22 \mathrm{dbar}$ (2013 and 2016). The mean thermocline depth in August over the whole Argo dataset was $18 \mathrm{dbar}$ (Figure 5).

\footnotetext{
${ }^{3}$ https://anaconda.org/pypi/gsw
} 


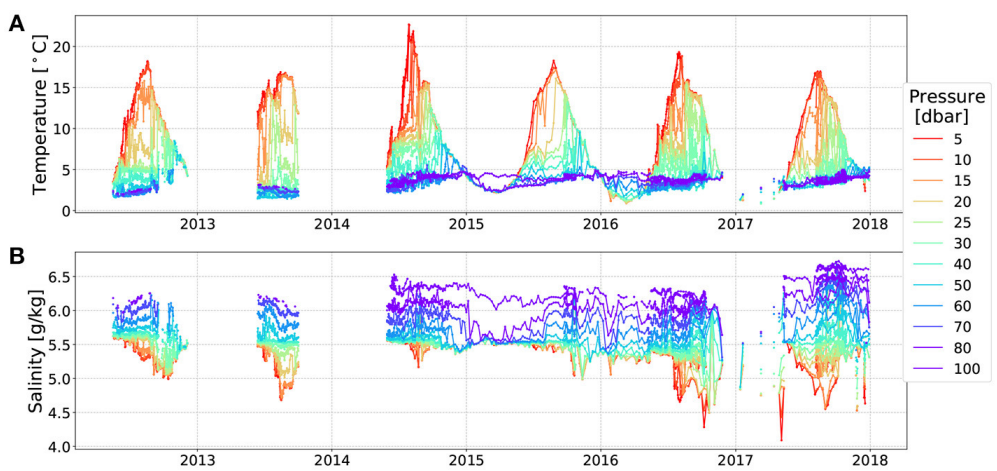

FIGURE 3 | Time series of (A) temperature and (B) salinity at HELCOM standard depths from the Argo floats.
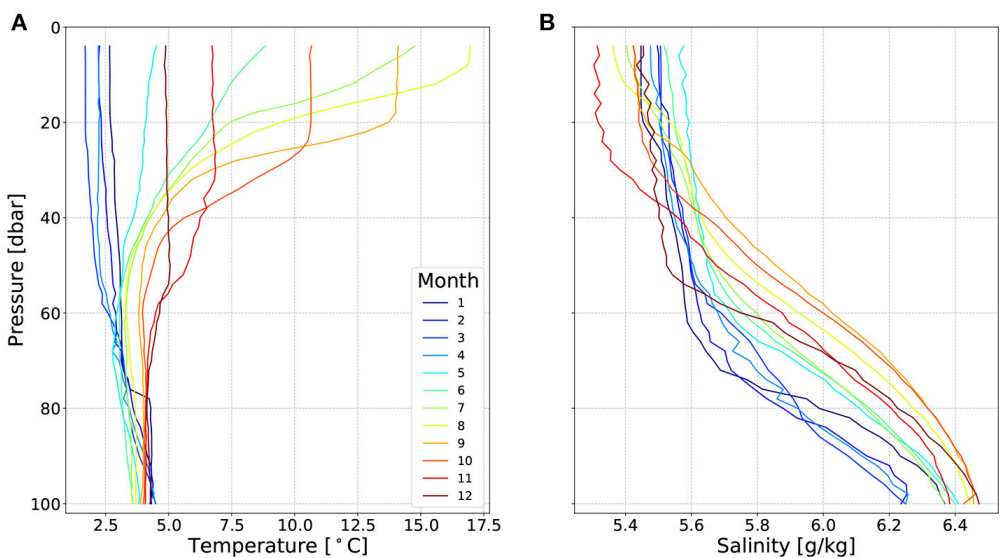

FIGURE 4 | Monthly mean profiles of (A) temperature and (B) salinity from Argo data. Profiles for months 1-4 include only 2015-2017 data due to lack of profiles and the other months include the entire dataset period of 2012-2017. Data above 4 dbar and below 100 dbar were cut off due to sparse measurements.

Measured salinity range close to surface was from $4.18 \mathrm{~g} \mathrm{~kg}^{-1}$ (5.5.2017, float 6902023) to $5.74 \mathrm{~g} \mathrm{~kg}^{-1}(2.6 .2012$, float 6901901$)$ (Figure 3B). For $100 \mathrm{dbar}$ depth the minimum and maximum values were $5.99 \mathrm{~g} \mathrm{~kg}^{-1}(18.11 .2016$, float 6902023) and $6.83 \mathrm{~g} \mathrm{~kg}^{-1}$ (7.10.2017, float 6902028), respectively. The variation of the monthly mean of salinity close to surface was 5.31$5.60 \mathrm{~g} \mathrm{~kg}^{-1}$ with highest values in May before the thermocline has developed and lowest in August when the thermocline restricts the mixing of freshwater runoff with the underlaying watermass. At $100 \mathrm{dbar}$ the range of monthly mean salinity was $6.24-6.47 \mathrm{~g} \mathrm{~kg}^{-1}$ with highest values in the autumn and lowest in the spring around the time of spring overturning Figure 4B. The halocline was on average deepest, at $90 \mathrm{dbar}$, in February, and shallowest, at about $58 \mathrm{dbar}$, in August, when the thermocline was the strongest (Figure 5). The average halocline depth for the entire period 2012-2017 was at 67 dbar. Salinity below the halocline along the Bothnian Sea deep area was $0.33 \mathrm{~g} \mathrm{~kg}^{-1}$ higher in 2017 than in in 2012-2016, whereas the halocline depth has shallowed since 2015, when the mean below halocline salinity was lowest (Figure 3B).

The mean temperatures measured with the floats fit to those commonly presented in literature for the Bothnian Sea (Lentz, 1971), although the summer mean temperature is a couple of degrees warmer and bottom temperature variation is smaller. The record warm year 2014 showed as high near surface and mixed layer temperature, and this is reflected in the results. The smaller bottom variation compared to previously presented is most likely explained by sparse winter profiles and the lack of profiles from the shallow edge of the Archipelago Sea, where seasonal mixing can reach the bottom easier. Salinity both close to surface and below halocline was also on average in the limits of what is presented in Bock (1971) but the values were mostly at the lower end of the range and variation smaller. This is probably also caused by scarcity of profiles close to the sill to the Åland Sea. The 
A

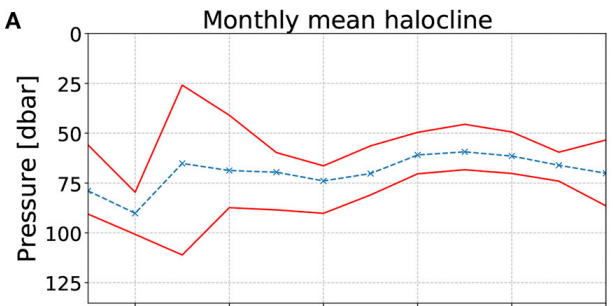

C

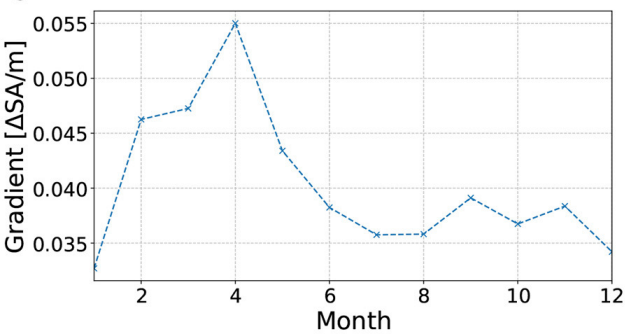

B

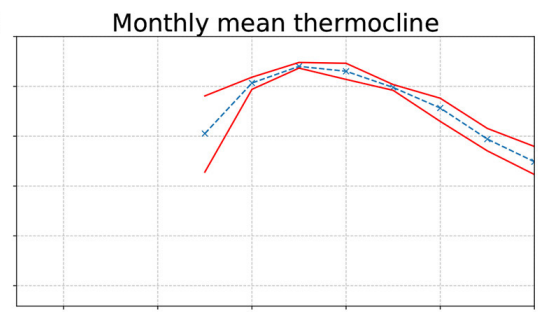

D

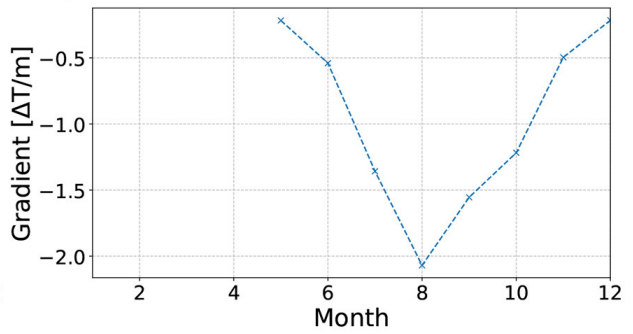

FIGURE 5 | Monthly means of (A) halocline and (B) thermocline depth and the strength of (C) salinity and (D) temperature gradients at the pycnocline depths calculated from Argo data. Means for months 1-4 include only 2015-2017 data due to lack of profiles and the other months include the entire dataset period of 2012-2017. The red lines in (A,B) show the maximum and minimum depths of halocline and thermocline for each month.

monthly halocline depth here was similar to those presented by Haapala and Alenius (1994), although here the maximum depth of the halocline occurred earlier in the Spring (Figure 5). This is most likely also due to the small amount of winter profiles, which amplifies the impact of the available years.

The mean salinity below the halocline in 2017 was $0.3 \mathrm{~g} \mathrm{~kg}^{-1}$ higher than between 1998 and 2016, both compared to the CTD data and the Argo profile data. Compared to the long time series of salinity from the Bothnian Sea from 1900's onwards the salinity in 2017 is well inside the observed variability, but still highest in the Bothnian Sea during the 21'st century. The drivers for this salinity change could be many and certainly require further research. One reason might be the major Baltic inflows (MBI) in 2014-2016, which pushed saline water from the Northern Baltic Proper to the Gulf of Finland, where record high bottom salinities were measured in the end of 2016. The MBI's could have had an impact on the Bothnian Sea bottom salinity as well, although the water has to pass multiple sills to reach the basin. However, a change in the halocline depth or it's salinity could influence the Bothnian Sea, since the deep water of the Bothnian Sea originates from the water above the Southern Quark sill depth of $60-70 \mathrm{~m}$ in the Northern Baltic Proper (Hietala et al., 2007). Also, change in wind conditions or runoff from land may also have affected the change in stratification in the Bothnian Sea. In a modeling study by Väli et al. (2013) a strong negative correlation between accumulated river runoff and below halocline salinity, as well as westerly winds and below halocline salinity were found. Compared to the climatological period 1981-2010 during 2017 there were $2-3 \%$ more westerly winds and less easterly winds, but the accumulated precipitation along the Finnish coast of the Gulf of Bothnia was smaller than the rest of 2010's and the 1981-2010 average. Especially in Oulu and Vaasa, the yearly precipitation was on average $118 \%$ of the normal period average, while in 2017 it was $95 \%{ }^{4}$.

\subsection{Spatial and Temporal Scale Variability From Argo Profiles}

We analyzed areal similarity and the significance of the profiling frequency in the Bothnian Sea by comparing three simultaneous missions from autumn 2017 between 06.08.27.10.2017 (6902025, 6902028 and 6902029). In the Baltic Sea the size of an area where the water mass can be regarded as homogeneous in a climatological sense was defined as $30^{\prime} \times 1^{\circ}$ (latitude $\mathrm{x}$ longitude) or $55 \mathrm{x} 55 \mathrm{~km}$ by Haapala and Alenius (1994). The same definition seems to apply for the short term Argo data as well. Floats 6902028 and 6902029 were within $50 \mathrm{~km}$ radius from each other for $75 \%$ of the duration of mission 6902029 , with the maximum distance between them being $61 \mathrm{~km}$. The hydrographic features their data showed were very similar (Figure 6). Float 6902025 drifted more to the north, with a 50$100 \mathrm{~km}$ distance to the other floats, to an area with less saline water above halocline. The north-south gradient in salinity is known to be dominant in the Bothnian Sea (for example Janssen et al., 1999). The shape of the T-S-diagram for float 6902025 is similar to those of 6902028 and 6902029 , which indicates that the temperature dynamics in the open sea along the Bothnian Sea deep are not strongly dependent of latitude.

\footnotetext{
${ }^{4}$ http://en.ilmatieteenlaitos.fi/statistics-from-1961-onwards
} 


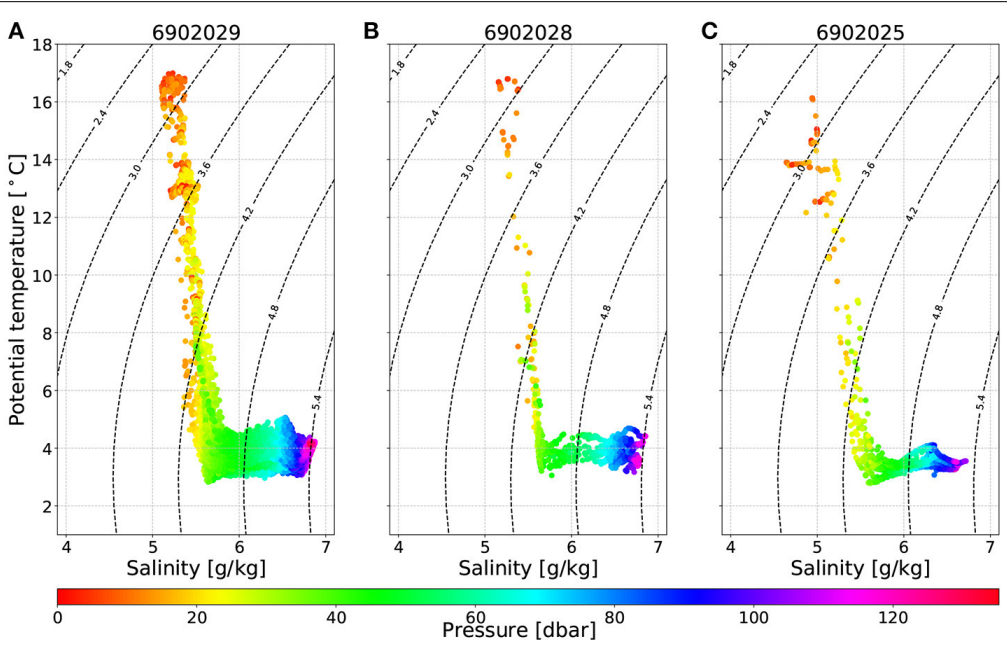

FIGURE 6 | T-S diagrams of for deployments (A) 6902029, (B) 6902028, and (C) 6902025. Colors show pressure of measurement points.

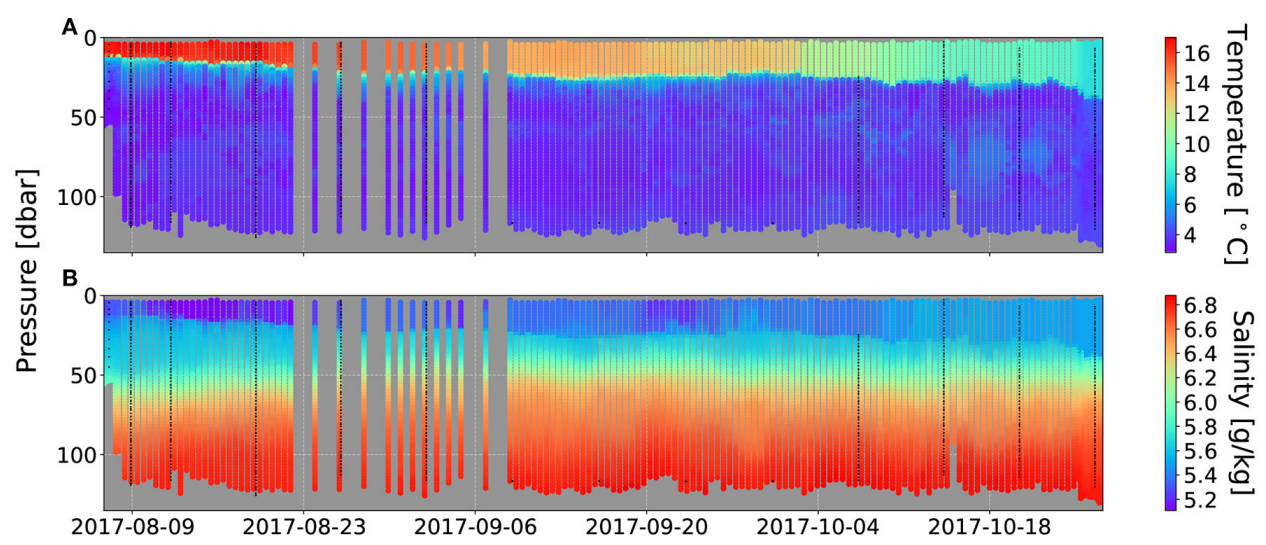

FIGURE 7 | (A) Temperature and (B) absolute salinity profiles from float 6902029 . Black dotted lines show timing of profiles of float 6902028 during the same period. The gray shade is the background color and indicates that no data is available.

The high profiling frequency, one cycle every day (Table 2), of float 6902029 revealed more fluctuation in water temperature and variation in salinity above the halocline, than what float 6902028 captured with a weekly profiling schedule (Figure 7). The cooling of the mixed layer and the decay of the thermocline were recorded in more detail than previously has been possible in this area.

In the end of October float 6902029 was set to do continuous profiling to capture a predicted storm. The resulting dataset has profiles every $2 \mathrm{~h}$ and it is the first of it's kind in the Bothnian Sea. It reveals a $10 \mathrm{dbar}$ deepening of the thermocline from 30 to $40 \mathrm{dbar}$, and a cooling of the mixed layer by $0.9^{\circ} \mathrm{C}$ in
$24 \mathrm{~h}$ between 25.-26.10.2017. This successful short term event monitoring with continuous profiling is a good example of the different observation routines possible with Argo floats with twoway communication. The storm was noticed in the forecast in time and the new settings for the float were delivered before the storm reached the Bothnian Sea. A profiling resolution of 2-3 $\mathrm{h}$, which is likely the fastest possible with the depth range of 100-150 m, was achieved.

There was a lot of variation in the surface mixed layer salinity, with values ranging from 5.11 to $5.54 \mathrm{~g} \mathrm{~kg}^{-1}$ during the 2.5 months. In August there was a 5 day period with $1.5 \mathrm{~g} \mathrm{~kg}^{-1}$ less saline water in the surface mixed layer than the surrounding 

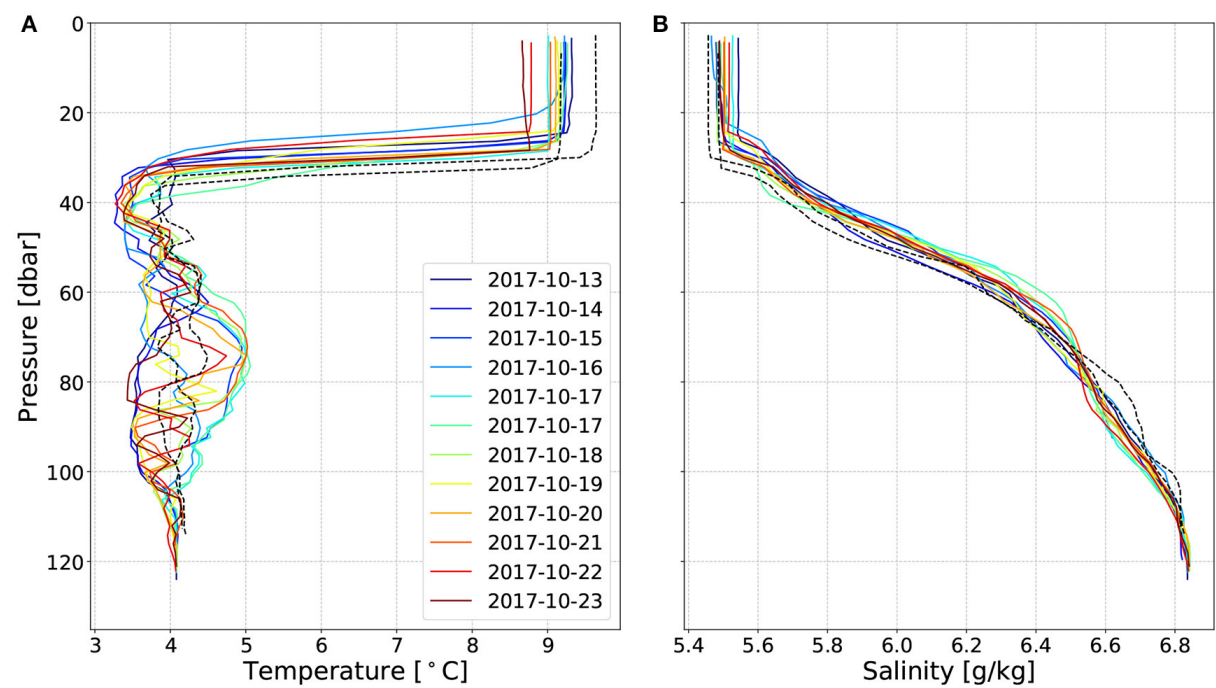

FIGURE 8 | (A) Temperature and (B) salinity profiles measured by float 6902029 between 13.-24.10.2017. The dashed black lines show the profiles from float 6902028 from the same time period.

days, which could be an advected lens of less saline water. An oscillation of the halocline depth between 40 and $60 \mathrm{dbar}$ was also observed during the mission.

After October 15, 2017 two lenses of relatively warm water were measured below the halocline between 60 and $100 \mathrm{dbar}$ (Figure 8). The temperature of these lenses was up to $5.1{ }^{\circ} \mathrm{C}$, while the mean temperature of the layer was $3.8^{\circ} \mathrm{C}$. The event lasted around 10 days, after which the ambient temperature returned close to the mean. The float drifted approximately $9 \mathrm{~km}$ during the event. Prevailing wind direction at Märket automatic weather station between 5.-10.10. was between NW-NE and on the 13.10. there were $15 \mathrm{~m} \mathrm{~s}^{-1}$ winds from the North. These northerly winds may have caused downwelling on the Swedish side of the Bothnian Sea and at the edge of Finngrunden shoals. The float drifted close to the eastern edge of Finngrunden for the entire mission (white line in Figure 1).

Most of these phenomena were either completely missed with float 6902028 because of them falling in between profiles (see the black dots in Figure 7), or their duration and magnitude was not fully captured. For example the storm was left in between profiles, as well as the warm water lenses.

\section{DISCUSSION}

\subsection{Argo Floats vs Traditional Ship Monitoring}

After the start of regular Argo observations in the Bothnian Sea in 2012, 166 ship borne CTD profiles have been measured. Only three monitoring stations coincide with the Argo float deployment area (red rectangle in Figure 1), and six out of the 166 CTD profiles were measured at these stations. The most commonly visited standard monitoring stations SR5, F26, and US5B fall outside the main Argo drifting areas. Since temporal coverage of Argo floats in the Bothnian Sea is much larger than that of shipborne CTD profiling (Figure 2), Argo floats can capture extreme values, as well as synoptic to storm scale dynamics which are not possible to obtain with seasonal ship monitoring.

Because Argo floats measure more frequently, they capture the warming of the mixed layer and the development of the thermocline in early summer, the temperature maximum and variation during summer, and the cooling and decay of the thermocline in the autumn, whereas the ship monitoring brings out at best only the interannual variability of the water column at certain monitoring stations. Usually the summer COMBINE monitoring cruises take place in June and August, so the highest surface temperature, that occurs at the edge of July-August, and thermocline strength are often missed. During 2012-2017 the Argo floats recorded up to $5^{\circ} \mathrm{C}$ warmer temperatures in the surface layer than ship monitoring (Figure 9A). On the other hand minimum temperatures captured by ship profiling were lower than those by Argo floats in the entire water column. This can be mainly explained by the temporal coverage of the Argo data, since until now, there is very little data from winter time. The wider range in temperature in the CTD profiles below $80 \mathrm{dbar}$ could be explained with spatial variation, the CTD data covers the Southern Quark better than the Argo data. Due to the larger areal coverage of the ship monitoring data, it includes data from shallower areas, where the use of Argo float is not optimal and also from deeper areas, such as the Ulvö deep, which have not yet been monitored with Argo floats. When only the area in which the Argo floats are deployed and from where there is most 

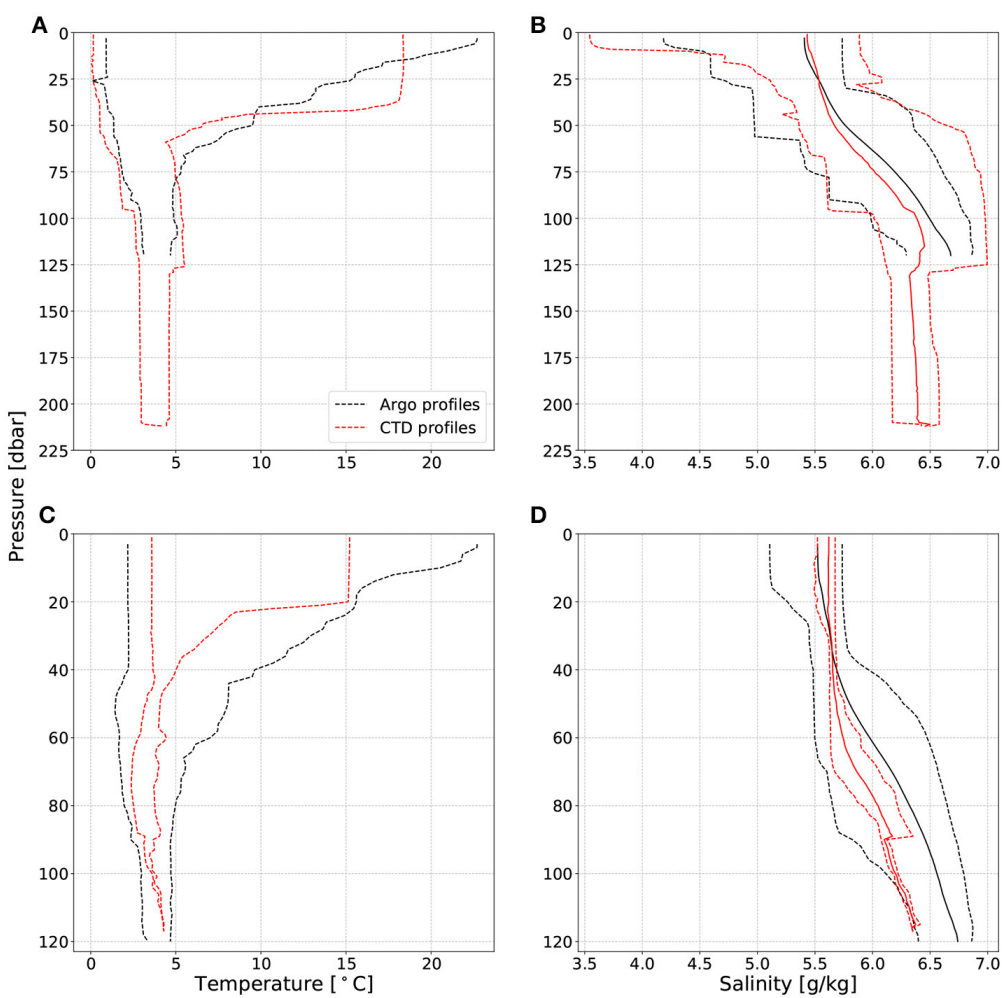

FIGURE 9 | Ranges (dashed lines) and means (solid lines in B,D) of (A,C) temperature and (B,D) salinity data from Argo data (black) and ship CTD (red) from (A,B) the entire Bothnian Sea and from (C,D) the Argo float deployment area shown as a red rectangle in Figure $\mathbf{1}$ between 2012 and 2017. The locations of the CTD profiles are also shown in Figure 1.

data available (the zoomed in area in Figure 1) is considered, then the variability captured with Argo floats is $10^{\circ} \mathrm{C}$ more than with CTD (Figure 9).

The range of salinity in the entire Bothnian Sea was larger in the CTD data than in the Argo data, especially close to surface, where CTD profiles show up to $1 \mathrm{~g} \mathrm{~kg}^{-1}$ lower values. Since a horizontal gradient in salinity exists in the Bothnian Sea, it is to be expected that with a ship, not confined in the deep area, the extreme values are better reached. Argo floats recorded less saline cases between $10-75 \mathrm{dbar}$, but their profile mean was higher than that of the shipborne CTD profiles. However, in the float deployment area it can be seen that the temporal variability in salinity is much better captured by the Argo floats.

\subsection{Monitoring Bothnian Sea Hydrography as a Whole}

We have presented in this paper a new addition to the monitoring of the Bothnian Sea hydrography, the Argo floats. However, there are also other new automated measurement systems, such as gliders, that deserve to be mentioned and discussed. And also existing in-situ moorings, satellite data and FerryBox systems that already are, in addition to the traditional research vessel monitoring, an essential part of the monitoring of the state of the Bothnian Sea.

Due to the seasonal ice cover in the Bothnian Sea, maintenance of in-situ moorings is challenging and therefore they are currently limited only to few operational surface temperature buoys, located close to the shoreline and two wave buoys, which also include a temperature sensor. These surface buoys operate only during the ice-free season and need to be recovered well before the ice season starts. Therefore, they do not cover the full seasonal cycle, but provide a good overview of the late spring, summer, and autumn SST dynamics at their locations.

FerryBox systems offer continuous data from the near-surface level from designated ship routes. Presently there is one FerryBox operating in the Gulf of Bothnia (route Gothenburg-Kemi-OuluLübeck-Gothenburg). The quality of the temperature and salinity measurements has been found good by Karlson et al. (2016) when compared to other field measurements and together with other measurements to complement the traditional monitoring data in the Baltic Sea. 
In addition to these in-situ measurements, satellites provide a good coverage of the sea surface. Sea surface temperature has been observed with satellites for a long time and daily SST maps are provided in services such as the Copernicus Marine and Environment Monitoring System (CMEMS) ${ }^{5}$. Also SSS can be obtained from satellites, but presently the resolution and quality of the products are not good enough in the Baltic Sea, but maybe new progress will improve that (Olmedo et al., 2016).

To obtain more T-S-profile measurements, FMI has recently started to operate a glider to measure the hydrography in the southeastern part of the Bothnian Sea. Presently there have been two measurement campaigns during Autumns 2016 and 2017 (Alenius et al., 2018). Compared to Argo floats that drift freely with currents, the gliders can be navigated along predetermined routes. The vertical coverage of measurements is slightly better than with Argos, since the FMI glider has an altimeter, which allows the glider to dive close, c. 3-5 $\mathrm{m}$, to the bottom. The ice season sets limits to the operation of gliders in the northern Baltic Sea. Liblik et al. (2016) state in their analysis of the potential of underwater gliders in global observing system that under ice operations have still been limited for gliders, but shown to be feasible by e.g., Beszczynska Möller et al. (2011). The gliders have not yet been used for regular monitoring in the Baltic Sea, but have shown their potential to be a good addition to the monitoring. They are, however, significantly more expensive than Argo floats and require more piloting and maintenance.

The present state-of-the-art 3D ocean models, such as the NEMO-Nordic Hordoir et al. (2018), are able to depict the Baltic Sea hydrography fairly well. For example Westerlund and Tuomi (2016) have shown that the vertical temperature and salinity structure and the seasonal development of thermocline in the Bothnian Sea were modeled with relatively good accuracy. However, they also showed, with the help of Argo float data, that there is a need for improvement in the model physics and parameterization in order to better describe the complex stratification conditions of the Baltic Sea. The accuracy of the 3D models can be improved by introducing assimilation of both surface and profile data as has been shown e.g., by Axell and Liu (2016) in the Baltic Sea.

\section{CONCLUSION}

Hydrography of the Bothnian Sea during 2012-2017 was estimated based on Argo data as a separate dataset, and then Argo data were compared to CTD profiles from the same time period and to historical CTD measurements.

For the first time we were able to observe the seasonal cycle of the water column in the open sea areas of the Bothnian Sea on a weekly scale. The timing of spring and autumn overturning and the development and decay of the thermocline can now be followed in much more detail than is possible with ship monitoring. With continuous in-situ profiling the phase of the yearly thermal cycle of the water column can be followed and

\footnotetext{
${ }^{5} \mathrm{http}: / /$ marine.copernicus.eu
}

compared to previous years to monitor changes in the cycle, much like Leppäranta et al. (1988) did with the ice season. This knowledge can be used to predict, for example, the upcoming ice winter or timing and magnitude of summer algae blooms.

The Argo floats seem to work well as an independent monitoring system for temperature dynamics in the Bothnian Sea. Since salinity is a more conservative and location dependent variable, the gradual changes in it may be better observed with long term station monitoring, but small and short scale phenomena are captured well. It was shown that the float profiling schedule is flexible and can be adjusted to fit the needs of both standard monitoring and short term event observation. The possibility to adjust the float behavior according to weather forecasts provides a great method to (a) achieve long term deployments with weekly profiles and longer battery life with still the option to get occasional fast profiling sequences and (b) get data from storms where normal research vessel operations would be difficult or not possible. There are very little measured T-Sprofiles from storm situations in the Bothnian Sea. Achieving data from upper mixed layer dynamics during a storm will give valuable data e.g., for process studies and model development.

The Argo floats and ship monitoring supplement each other. The long time series from fixed monitoring stations with high vertical resolution from ships gives reference to the magnitude of short term variability measured with Argo floats, and the spatially variable high temporal resolution profiling with Argo floats gives insight of the possible phenomena behind anomalies seen in the temporally sparse monitoring data. The floats also contribute to the long term standard monitoring time series whenever they drift past a monitoring station. The Argo floats are confined in the deep area of the Bothnian Sea, so their data mostly represents the South-North variability in the water column.

For now, we have missed the top $4 \mathrm{~m}$ of the water column because of the limitation set by the CTD sensor design. Switching to an alternative sensor would enable even better monitoring of the mixed layer, which would then make prediction of for example algal blooms easier. Gaining weekly to daily sea surface observations would also support validation of sea surface remote sensing.

Despite the challenging environment in the Bothnian Sea, the Argo floats were found to function well and they have become an important part of the monitoring network. Even though the floats often touch the bottom and occasionally get stuck in the bottom, they have so far always managed to free themselves. The ice avoidance algorithm was also determined to be functioning as expected and we have managed to retrieve all our floats so far.

For future work it would be interesting to assess the Bothnian Sea observing system in it's current state as done by Grayek et al. (2015) in the Black Sea to see what improvements could be made regarding the now existing Argo operations. Grayek et al. (2015) concluded that for the Black Sea a good amount of floats is 10 and that adding more floats instead of increasing profiling frequency gives best results at least for data assimilation. Most important questions are how many floats are enough to capture the instantaneous state of 
the Bothnian Sea sufficiently, and what is the best profiling frequency for long term monitoring and for the needs of forecasting.

\section{AUTHOR CONTRIBUTIONS}

$\mathrm{NH}$ wrote the first draft with significant help from LT and was the main responsible for the analysis of the observation data and producing the illustrations. PR, S-MS, LT, and PA contributed to the illustrations. Background research was mainly done by $\mathrm{NH}, \mathrm{PR}$, and PA. TP was responsible for the technical support and acquisition of data. All authors contributed to the evaluation of the data, wrote sections for this manuscript and revised and approved the sent version.

\section{ACKNOWLEDGMENTS}

The Argo data used in this work were collected and made freely available by the International Argo Program and the national programs that contribute to it. (http://www.argo.ucsd.edu, http:// argo.jcommops.org). The Argo Program is part of the Global Ocean Observing System. This work has been partly supported by the Strategic Research Council at the Academy of Finland, project SmartSea (grant number 292 985).

\section{REFERENCES}

Alenius, P., Tikka, K., Lips, U., Tuomi, L., Purokoski, T., Roiha, P., et al. (2018). "Euro-Argo in work and new potential of gliders in the Baltic Sea BOOS," in Operational Oceanography serving Sustainable Marine Development. Proceedings of the Eight EuroGOOS International Conference, eds E. Buch, V. Fernández, D. Eparkhina, and Gorringe, P., and G. Nolan (Bergen), 143-148.

Argo (2000). Argo Float Data and Metadata From Global Data Assembly Centre (Argo GDAC). SEANOE.

Argo Data Management Team (2017). Argo User's Manual V3.2. http://doi.org/10. $13155 / 29825$

Axell, L., and Liu, Y. (2016). Application of 3-d ensemble variational data assimilation to a baltic sea reanalysis 1989-2013. Tellus A Dynam. Meteorol. Oceanogr. 68:24220. doi: 10.3402/tellusa.v68.24220

Beszczynska Möller, A., Woodgate, R., Lee, C., Melling, H., and Karcher, M. (2011). A synthesis of exchanges through the main oceanic gateways to the Arctic Ocean. Oceanography 24, 82-99. doi: 10.5670/oceanog.2011.59

Bock, K. H. (1971). Monatskarten des salzgehalten der ostsee, dargestellt für verschiedene tiefenhorisonte [monthly salinity maps of the Baltic Sea for different depths]. Deutsch. Hydrogr. Z. Ergänzungshäft Reihe B 12, 1-147.

Fonselius, S. (1996). Västerhavets och Östersjöns Oceanografi. Norrköping: SMHI.

Grayek, S., Stanev, E. V., and Schulz-Stellenfleth, J. (2015). Assessment of the Black Sea observing system. A focus on 2005-2012 Argo campaigns. Ocean Dynam. 65, 1665-1684. doi: 10.1007/s10236-015-0889-8

Håkansson, B., Alenius, P., and Brydsten, L. (1996). Physical Environment in the Gulf of Bothnia. Ambio, 8, 5-12.

Haapala, J., and Alenius, P. (1994). Temperature and salinity statistics for the northern Baltic Sea 1961-1990. Finnish Mar. Res. 262, 51-121.

HELCOM (2014). Manual for Marine Monitoring in the COMBINE Programme of HELCOM. HELCOM.

Hietala, R., Lundberg, P., and Nilsson, J. A. (2007). A note on the deep-water inflow to the Bothnian Sea. J. Mar. Syst. 68, 255-264. doi: 10.1016/j.jmarsys.2006.12.004

Hordoir, R., Axell, L., Höglund, A., Dieterich, C., Fransner, F., Gröger, M., et al. (2018). Nemo-Nordic 1.0: a NEMO based ocean model for Baltic \& North Seas, research and operational applications. Geosci. Model Dev Discuss. 2018, 1-29. doi: 10.5194/gmd-2018-2

IOC, SCOR, and IAPSO (2010). The International Thermodynamic Equation of Seawater-2010: Calculation and Use of Thermodynamic Properties. Number 56 in Intergovernmental Oceanographic Commission, Manuals and Guides. UNESCO.

Janssen, F., Schrum, C., and Backhaus, J. O. (1999). A climatological data set of temperature and salinity for the Baltic Sea and the North Sea. Deutsch. Hydrogr. Z. 51:5.

Karlson, B., Andersson, L., Kaitala, S., Kronsell, J., Mohlin, M., Seppälä, J., et al. (2016). A comparison of FerryBox data vs. monitoring data from research vessels for near surface waters of the Baltic Sea and the Kattegat. J. Mar. Syst. 162, 98-111. doi: 10.1016/j.jmarsys.2016.05.002

Kassis, D., Korres, G., Petihakis, G., and Perivoliotis, L. (2015). Hydrodynamic variability of the Cretan Sea derived from Argo float profiles and multi-parametric buoy measurements during 2010-2012. Ocean Dynam. 65, 1585-1601. doi: 10.1007/s10236-015-0892-0

Lentz, W. (1971). Monatskarte der Temperatur der Ostsee dargestellt für verschiedene Tiefenhorisonte [Monthly maps of the temperature of the Baltic Sea for different depths]. Deutsch. Hydrogr. Z. Ergänzungshäft Reihe B 11, $1-148$.

Leppäranta, M., Palosuo, E., Grönvall, H., Kalliosaari, S., and Seinä, A. (1988). Itämeren jäätalven vaiheet (leveyspiiristä $57^{\circ} \mathrm{N}$ pohjoiseen) [Ice phases in the Baltic Sea, north of latitude $\left.57^{\circ} \mathrm{N}\right]$. Finnish Mar. Res. 254, 1-83.

Liblik, T., Karstensen, J., Testore, P., Alenius, P., Hayes, D., Ruiz, S., et al. (2016). Potential for an underwater glider component as part of the Global Ocean Observing System. Methods Oceanogr. 17, 50-82. doi: 10.1016/j.mio.2016.05.001

Olmedo, E., Martínez, J., Umbert, M., Hoareau, N., Portabella, M., BallabreraPoy, J., et al. (2016). Improving time and space resolution of SMOS salinity maps using multifractal fusion. Remote Sens. Environ. 180, 246-263. doi: $10.1016 /$ j.rse.2016.02.038

Pettersson, O. and Ekman, G. (1897). De Hydrografiska Förändringarne Inom Nordsjöns Och Östersjöns Områade Under Tiden 1893-1897, volume 29 of Kongliga Svenska Vetenskaps-Akademiens Handlingar. Kungl. boktryckeriet. P.A. Norstedt \& Söner

Purokoski, T., Aro, E., and Nummelin, A. (2013). First long-term deployment of Argo Float in Baltic Sea. Sea Technol. 54, 41-44.

Roiha, P., Siiriä, S., Alenius, P., Haavisto, N., Westerlund, A., and Purokoski, T. (2018). Estimating currents from Argo Trajectories in the Bothnian Sea, Baltic Sea. Front. Mar. Sci. 5:308. doi: 10.3389/fmars.2018.00308

Seifert, T., Tauber, F., and Kayser, B. (2001). "A high resolution spherical grid topography of the Baltic Sea - 2nd Edn.," in Baltic Sea Science Congress (Stockholm), Poster \#147. Available online at: www.io-warnemuende.de/iowtopo

Teledyne Webb Research, Inc. (2013). APF-11 APEX Profiling Float User Manual, Rev. 2 Edn. North Falmouth.

Väli, G., Meier, H. E. M., and Elken, J. (2013). Simulated halocline variability in the Baltic Sea and its impact on hypoxia during 1961-2007. J. Geophys. Res. Oceans 118, 6982-7000. doi: 10.1002/2013JC009192

Westerlund, A., and Tuomi, L. (2016). Vertical temperature dynamics in the Northern Baltic Sea based on 3d modelling and data from shallow-water Argo floats. J. Mar. Syst. 158, 34-44. doi: 10.1016/j.jmarsys.2016.01.006

Conflict of Interest Statement: The authors declare that the research was conducted in the absence of any commercial or financial relationships that could be construed as a potential conflict of interest.

Copyright ( 2018 Haavisto, Tuomi, Roiha, Siiriä, Alenius and Purokoski. This is an open-access article distributed under the terms of the Creative Commons Attribution License (CC BY). The use, distribution or reproduction in other forums is permitted, provided the original author(s) and the copyright owner(s) are credited and that the original publication in this journal is cited, in accordance with accepted academic practice. No use, distribution or reproduction is permitted which does not comply with these terms. 


\section{Publication III}

Petra Roiha, Simo-Matti Siiriä, Noora Haavisto, Pekka Alenius, Antti Westerlund and Tero Purokoski. Estimating currents from Argo trajectories in the Bothnian Sea, Baltic Sea. Frontiers in Marine Science, 5:308, doi:10.3389/fmars.2018.00308, 2018. 



\section{OPEN ACCESS}

Edited by:

Elinor Andrén,

Södertörn University, Sweden

Reviewed by:

Taavi Liblik,

Tallinn University of Technology,

Estonia

Alexander B. Rabinovich,

P.P. Shirshov Institute of Oceanology (RAS), Russia

*Correspondence: Petra Roiha petra.roiha@fmi.fi

Specialty section

This article was submitted to Coastal Ocean Processes,

a section of the journal

Frontiers in Marine Science

Received: 13 March 2018

Accepted: 10 August 2018

Published: 12 September 2018

Citation:

Roiha P, Siiriä S-M, Haavisto $N$,

Alenius $P$, Westerlund $A$ and

Purokoski T (2018) Estimating

Currents From Argo Trajectories in the

Bothnian Sea, Baltic Sea.

Front. Mar. Sci. 5:308

doi: 10.3389/fmars.2018.00308

\section{Estimating Currents From Argo Trajectories in the Bothnian Sea, Baltic Sea}

\author{
Petra Roiha ${ }^{1 *}$, Simo-Matti Siiriä ${ }^{1}$, Noora Haavisto ${ }^{1,2}$, Pekka Alenius ${ }^{1}$, Antti Westerlund ${ }^{1}$ \\ and Tero Purokoski ${ }^{1}$
}

${ }^{1}$ Marine Research Unit, Finnish Meteorological Institute, Helsinki, Finland, ${ }^{2}$ Tvärminne Zoological Station, University of Helsinki, Helsinki, Finland

Argo floats have been used in the environmental monitoring of the very shallow Bothnian Sea, a sub-basin of the Baltic Sea, for 5 years as part of the Finnish Euro-Argo programme. The Bothnian Sea is so far considered to be an environmentally healthy part of the Baltic Sea because the deep waters of the basin are well-ventilated by inflowing oxygen-rich saltier and heavier surface layer waters of the Baltic Sea proper. Thus the deep water flow is of interest in the Bothnian Sea. In this study, we used Argo float data from six different long-term missions, from 111 to 512 days, to analyze the deep-water flow in the Bothnian Sea where no continuous monitoring of currents exist. We estimated mainly the flow below the expected halocline from the paths of the floats. We analyzed the movements statistically and estimated the error caused by the surface drift of the floats during their stay at the surface by using 3D hydrodynamic model results as reference data. Our results show a northward flowing resultant current in the deep trench of the Bothnian Sea. There seemed to be very little exchange between coastal zone and open-sea waters in deeper layers. The drifting speed of the floats in the deep layers of Bothnian Sea generally was around $2 \mathrm{~cm} / \mathrm{s}$ but instantaneous speeds of up to $30 \mathrm{~cm} / \mathrm{s}$ in the middle-layer (50 dbars) were observed. In the Bothnian Sea deep, the deep trench on the Finnish side of the Bothnian Sea, the vast majority of the observations showed deep currents from south to north, with the same average speed of around 2 $\mathrm{cm} / \mathrm{s}$ but the instantaneous maximum was smaller at $13 \mathrm{~cm} / \mathrm{s}$. Our study indicates that the routine Argo float observations can be used to get information on the deep currents in the basin in addition to hydrographic observations.

Keywords: autonomous, measurement device, real-time, ocean observations, circulation, environmental monitoring, hydrography

\section{INTRODUCTION}

The Baltic Sea is a small shallow sea that consists of several basins with most of the deeper parts separated from each other by underwater sills. The water quality of the deep waters of the basins differ considerably from each other, although the whole Baltic Sea is more or less under loads from the land. For example, the marine ecosystems change because of nutrient and energy fluxes between the surface and benthos; the local climate and ice conditions depend on the energy storage of the sea and its movements. To know the deep currents and their variations is to be aware of potential changes in the environment. 
The dynamics of the deep areas of the Baltic Sea are still partly poorly known due to the limited quantity of measurements in these areas. Most of the studies that enlighten the deeper water layer dynamics concentrate on the Baltic Proper (e.g., Wieczorek, 2012), southern Baltic Sea (e.g., Bulczak et al., 2016), and Gulf of Finland (e.g., Suhhova et al., 2018) and are often related to examining the influence of major Baltic inflows on the deep water (Meier et al., 2006). Subsurface currents transport energy and substances, and they also have an effect on ecosystems by transporting the matter and the organisms.

The Bothnian Sea, a large sub-basin of the Baltic Sea, has been considered to be an environmentally healthy part of the vulnerable Baltic Sea, which suffers from environmental problems, the most severe of which is the oxygen deficit in the deep waters of the Baltic Sea Proper. Some concern on the slight worsening of the deep-water oxygen conditions in the Bothnian Sea was expressed by Raateoja (2013). The general understanding of the dynamics of the deep waters of the Bothnian Sea is that oxygen-rich saltier and heavier water from the surface layer of the Baltic Sea proper flow in to the Bothnian Sea and sinks toward the bottom and continues toward the north along the bottom, thus ventilating the deep-waters there (Hietala et al., 2007). This deep-water flow is of interest and should be monitored. However, there is no monitoring of currents in that open-sea area.

Kuosa et al. (2017) have studied the development of the Gulf of Bothnia ecosystem and concluded that variation in deepwater inflow from the Baltic Proper has an effect on phyto- and zooplankton communities in the Bothnian Sea.

The Finnish Meteorological Institute (FMI) has operated Argo floats in the Bothnian Sea already for 5 years as part of the Finnish Euro-Argo contribution. On average year the Bothnian Sea freezes almost completely (SMHI, 1982) and the floats are equipped with ice-avoidance algorithm. When ice avoidance is used the float is given a temperature value near freezing temperature (in the Bothnian Sea $0.25-0.5^{\circ} \mathrm{C}$ ). If the float detects freezing water it stops profiling and returns to the parking depth. In this study period no ice-avoidance was needed as the missions were performed in either ice-free period or in the area with no ice. However, the ice-avoidance was tested during this study with test value around $3^{\circ} \mathrm{C}$.

In this paper we study the possibility to utilize the Bothnian Sea Argo float data to estimate the deep currents below the pycnocline and thus add the value of the regular monitoring with these instruments. We analyzed the 5 years data of Argo float measurements from 2012 to 2016 to study the deep water movements in the Bothnian Sea in order to gain understanding of the processes affecting ecosystems there now and to be able in the future to predict the changes in the physical conditions. This type of data has far too coarse time resolution to reflect internal oscillations in the basin, like inertial ones and Bothnian Sea seiches. The results reflect more the net water transport in the deep layer.

\subsection{The Bothnian Sea}

The Bothnian Sea is located in the northern part of the Baltic Sea (Figure 1). It is generally shallow, with an average depth of 66 $\mathrm{m}$, but it is divided topographically different sections. There is relatively straight forward sloping bottom on the eastern side of the basin and an arch-shaped deep trench with maximum depth of $293 \mathrm{~m}$ in the north-western part of the basin. The area of the basin is $64886 \mathrm{~km}^{2}$ (Fonselius, 1996). The surface salinity in the open sea area is 5-6 and the deep-water salinity is 67 (Fonselius and Valderrama, 2003). The shoreline is near, and the area is important for marine traffic, nature conservation and fishing activities (Backer and Frias, 2013).

The northern parts and the coastal areas of the basin freeze or are near to the freezing point during the winter. The upper layer temperature is then smaller than maximum density temperature. In spring the surface temperature increases toward maximum density temperature, which causes overturning. In summer the temperature is greater than maximum density temperature and a seasonal thermocline forms. When the surface layer cools in the autumn toward maximum density temperature the surface layer overturns again. In winter the upper and deep layers are separated by a weak halocline, which also is a pycnocline, at somewhere between 70 and $90 \mathrm{~m}$ depths. The winter time convection reaches this pycnocline as interpreted from Argo data in the Bothnian Sea (Haavisto et al., 2018) and data from fixed oceanographic station at Utö (Haapala and Alenius, 1994).

The Bothnian Sea is a basin that is behind several smaller basins and sills that prevent the direct deep water flow from the Baltic Sea Proper. Thus the deep waters in the Bothnian Sea are formed during the winter from surface water from the Baltic Proper (Leppäranta and Myrberg, 2009). In last 20 years the saline water inflow to the deep layers of the Bothnian Sea has increased potentially by changes in sea-level dynamics in the Baltic Proper or the salinity content of the inflowing water (Raateoja, 2013). The deep water in the Gulf of Bothnia is mainly cooled winter water from the Gotland Sea, that has sunk over the southern Åland sill (Marmefelt and Omstedt, 1993). During the summer the deep water system resembles the deep water system in the Baltic Proper, with a strong thermocline and dicothermal layer. Then the direct wind mixing can only effect the layer that is on top of the thermocline, and deeper mixing can only happen when the thermocline disappears during spring and autumn overturning. This has a significant effect on the microbial ecosystem on the surface layer and oxygen conditions in the bottom layer (Raateoja, 2013).

The currents are induced in the sea by four different mechanisms: wind stress, sea surface tilt, horizontal thermohaline gradient of density and tidal forces (Leppäranta and Myrberg, 2009). The currents are altered by Coriolis acceleration, topography and friction. The period of the inertial oscillation is around $13.75 \mathrm{~h}$ in the southern Bothnian Sea and around $13.44 \mathrm{~h}$ in the Northern Bothnian Sea. River runoff could also change the local sea-level height and thus the currents. The passing low pressure cells often cause seiches in the Bothnian Sea. The theoretical uninodal seiche period for the Baltic Proper-Bothnian Sea system is $35.6 \mathrm{~h}$ and water-level observations suggest it might be as long as $39 \mathrm{~h}$ (Leppäranta and Myrberg, 2009). With Merian formula we may estimate that the uninodal seiche period accross the Bothnian Sea is $4.4 \mathrm{~h}$ and along the Bothnian Sea $7 \mathrm{~h}$. A northerly wind also drives the surface layer toward the south and west, causing upwelling on 


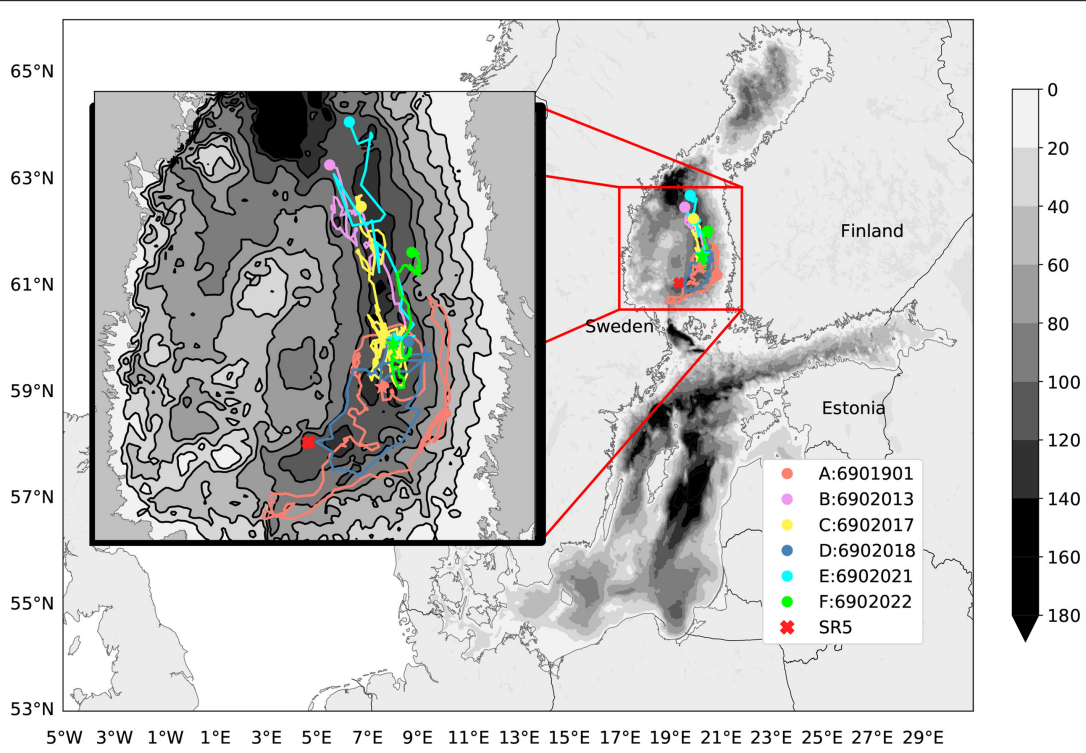

FIGURE 1 | Map of Argo missions in the Bothnian Sea 2012-2016. The deployment site of the floats is in a deep part of the Bothnian Sea. The starting and ending points are marked with stars and circles, respectively.The gray-scale shows the bathymetry. The cross marks the HELCOM continuous monitoring station, SR5.

the Finnish coast. The compensating current in the deep layer then flows toward the north.

The general concepts of the circulation in the Gulf of Bothnia were laid down in the early 20th century when Witting (1912) and Palmén (1930) studied the currents using observations from drift cards, ship borne current measurements and from light ships. They noticed that the main feature in the Bothnian Sea surface and near surface was a cyclonic circulation moving water to the north on the Finnish side of the basin and southwards on the Swedish side. Witting's works indicated two main circulation cells, one in the northern part of the Bothnian Sea and the other in the southern part. Palmén, however, concluded that there is only one basin-wide circulation cell, and that concept has been the basis of the general thinking since the 1930s.

Witting (1912) described the surface circulation separately for June, August, October and from June to October. He described the deep water movements in connection to water transports and gave figures for transports in spring and autumn. In that description the deep water transport goes down to the deep trench of the Bothnian Sea and rises upwards on the Swedish side where the depth of the sea is smaller. In both seasons the deep water transport is toward north.

The data on the deep water currents in the Bothnian Sea is sparse, and most of the measurements are concentrated in the southern part near the Understen-Märket trench, where the water exchange between the Baltic Sea Proper and the Bothnian Sea is taking place. Witting and Pettersson (1925) were the first to analyze the deep currents in that area in two short campaigns in the early 1920s. In the 1950s Hela (1958) studied the hydrography of the area. In the 1960s Palosuo (1964) studied the water exchange in the Alland Sea and the Quark and the routes of the water in the upper layers (15-40 m) of the Bothnian Sea.

In 1991 the Gulf of Bothnia Year programme aimed at a better understanding of the processes affecting on the ecosystem. This programme also included an intensive field observation of currents (e.g., Uotila et al., 1996). Coastal-open sea exchange processes as well as deep-sea mixing processes were scrutinized by using moored current meters and thermistor chains among others to gain insight into the structure and dynamics of the whole water column (Murthy et al., 1993). The current meter data from 8 and $60 \mathrm{~m}$ depth from a station with bottom depth of $112 \mathrm{~m}$, showed mainly northward going currents at both depth levels even in summer and inertial oscillations were sometimes present at both depths. Unfortunately even those datasets cannot answer to the question if there exists a two layer flow in the area under conditions when there is clear summer stratification.

Hietala et al. (2007) performed a measurement campaign with R/V Aranda to study with ship-mounted acoustic Doppler current profiler (ADCP) the currents in the Understen-Märket trench. 3D hydrodynamic modeling studies have also been executed to understand the water movements (e.g., Myrberg and Andrejev, 2006). These studies concentrate mainly on the near surface layers because there has not been good long-term observational data on the currents in the whole water column. The models today have achieved a certain maturity, but alongside the models we need observations to improve our understanding on the movement of water masses in the whole water column. 
Mesoscale phenomena on the surface have been also studied by remote sensing methods (Kahru et al., 1995), but those methods do not tell what happens in the deep layers.

\subsection{Argo Floats}

In the 1990s the time was right to start a global pursuit to automatically monitor the oceans' evolving temperature and salinity fields (Riser et al., 2016). The first global pursuit to survey the physical properties of the world oceans was the World Ocean Circulation Experiment (WOCE) (Woods, 1985). The global Argo programme was launched after WOCE and has been working since the year 2000 and it aims at real time monitoring of the world's oceans including sea areas that are difficult to reach by other means. Nowadays the main task of the floats is to measure the vertical distribution of basic hydrography fields and up to 80 additional parameters (Carval et al., 2015) at regular intervals and upload the data right after the measurements to the Internet. The floats have mostly been used in Open Ocean in areas where the depth is much more that $1,000 \mathrm{~m}$. In between the profile measurements, the floats drift freely with currents deep below the surface (Argo, 2000).

In general, floats are designed to be used in oceans where there is no danger of hitting the bottom or being hit by a ship while on the surface. Normally there is no need to change the diving parameters during the mission, and a one-way satellite transmission from float to shore is sufficient.

Usually the floats drift for about 10 days at a depth from 1 to $2 \mathrm{~km}$. While ascending, they collect profiles of at least the temperature and salinity, but other sensors might be included too. Once the float is at the surface, the measurement data as well as the float's GPS position is transmitted to the data collector via satellite. All the data from Argo floats is transmitted by satellite and made available in a public database. Thus, continuous measurement data becomes available from sea areas where insitu observations otherwise would be sparse (Le Traon, 2013). Currently, almost all deployed floats are in the deep oceans, with only a few operating in shallow, marginal seas.

The floats are successfully used to study currents in the deep oceans and shelf seas for example in the Black Sea (Korotaev et al., 2006), the Nordic Seas (Lavender et al., 2005; Voet et al., 2010), and the Mediterranean Sea (Menna and Poulain, 2010), too. The methods for analyzing the deep currents from the Argo data have been developed during the years (e.g., Park et al., 2005) In this study, we used the Argo data for the first time in analyzing currents in a shallow brackish water basin. With this data, we are able to achieve time series that cover most of the ice free seasons in the Bothnian Sea.

The Baltic Sea has a different operating environment than the oceans. With the aim of preventing the float from hitting the bottom and from drifting to shore, a much more active involvement with the float's mission is required. Therefore, to be able to change the diving parameters of the float, two-way satellite communication and short dive cycles are necessary requirements (Purokoski et al., 2013). The main cost of operating the floats is the manpower needed to keep watch on the floats. Benefit for this is the ability to react to interesting phenomena and increasing the observation frequency when needed.
The Finnish Meteorological Institute has used Argo floats in monitoring the Baltic Sea since the year 2012. At least two Argo floats have been continuously in the sea in the Gotland Deep, Baltic Sea Proper and in the Bothnian Sea. In our early Bothnian Sea Argo float missions, the floats were taken out from the sea for the ice-covered season, but later in the years 2015 and 2016 the floats have been equipped with ice avoidance system and they stay there also during the winter and a potentially icecovered period. The floats have been measuring in the areas where there are routine HELCOM monitoring stations but no dense time series. As the floats are kept away from the coast, they can be used to estimate the water movements in areas where so far only short-term deep current measurements have been done.

\section{MATERIALS AND METHODS}

\subsection{Bothnian Sea Argo Floats and Missions}

In January 2011, FMI received two floats specifically balanced for use in sea areas around Finland. These APEX (Autonomous Profiling Explorer) floats were manufactured by Teledyne Webb Research Corp. (East Falmouth, Massachusetts). Both of the floats were equipped with basic Sea-Bird Electronics Inc. (Bellevue, Washington) SBE 41CP CTD (ConductivityTemperature-Depth) sensors and a two-way Iridium satellite transmitter. Later a bio-optical float was also deployed to the Bothnian Sea (Table 1). The floats were especially balanced to function in brackish water. Since 2012, the measuring activity has been continuous.

There were altogether six missions in the years 2012-2016 done by three different floats (Table 2). FMI recovers the floats after missions and reuses them after service. Five of the missions were launched between mid-May and mid-June and one mission was launched in September. All the missions were launched near the same location in the middle of the Bothnian Sea deep to avoid bottom contact and collision with vessels. The deployment area is relatively deep and has a level bottom. During the winter time the ice avoidance was also tested in open water with ice avoidance temperature higher than exact ice avoidance temperature, but the largest number of observations are from the summer season. In later years, the number of winter measurements has also been increasing due to positive experiences with the ice-avoidance algorithm (Figure 2).

The typical measuring cycle starts when a float starts the diving procedure. When reaching the target pressure, the float stays at that depth, measuring pressure and temperature. After a pre-set diving time the float starts to measure the profile. Unlike the ocean, the profile is started from the parking depth (Figure 3). During the missions, the floats sometimes stayed on the surface during the diving cycle, hit the bottom, or did not send the complete log file. These occasions are removed from the analyzed datasets (Table 2).

From the Argo logs we can directly access the diving time, the time floated at the parking depth and the ascending time. When we know the total cycle time, we can estimate the time spent at the surface from those values. 
TABLE 1 | Technical details of the floats used in this study.

\begin{tabular}{|c|c|c|c|}
\hline & APE1 & APE2 & BAPE2 \\
\hline Modifications & & $\begin{array}{l}\text { Modified pressure detection } \\
\text { algorithm by FMl and Aalto University }\end{array}$ & \\
\hline Model & \multicolumn{3}{|c|}{ APEX-APF91 } \\
\hline Sensors & & Temperature, conductivity, pressure & $\begin{array}{c}\text { + Oxygen sensor Aanderaa Optode 4330 } \\
+ \text { fluorescence sensor and turbidity } \\
\text { sensor Wetlabs FLbb. }\end{array}$ \\
\hline Communications & \multicolumn{3}{|c|}{ 2-way Iridium satellite } \\
\hline
\end{tabular}

All three floats had a 2-way satellite connection and CTD equipment. APE2 had also modified pressure detection, and BAPE2 had additional oxygen, fluorescence and turbidity sensors.

TABLE 2 | Some statistics of Argo measurements in the Bothnian Sea 2012-2016.

\begin{tabular}{|c|c|c|c|c|c|c|c|c|}
\hline Mission & Float & Beginning & End & Total cycles & Valid cycles & $\begin{array}{l}\text { Median parking } \\
\text { pressure (dbar) }\end{array}$ & $\begin{array}{l}\text { Median speed } \\
(\mathrm{cm} / \mathrm{s})\end{array}$ & $\begin{array}{l}\text { Standard deviation } \\
\text { of speed }(\mathrm{cm} / \mathrm{s})\end{array}$ \\
\hline A : 6901901 & APE1 & 2012-05-17 & 2012-12-05 & 314 & 198 & 68 & 3.3 & 4.8 \\
\hline B : 6902013 & APE2 & 2013-06-13 & 2013-10-02 & 120 & 115 & 77 & 2.4 & 2.1 \\
\hline C : 6902017 & APE1 & 2014-05-30 & 2015-10-04 & 177 & 170 & 117 & 1.7 & 1.5 \\
\hline D : 6902018 & BAPE2 & 2014-05-30 & 2014-11-14 & 62 & 27 & 95 & 3.0 & 2.2 \\
\hline$E: 6902021$ & BAPE2 & 2015-09-23 & 2016-05-13 & 49 & 38 & 106 & 2.2 & 1.2 \\
\hline F : 6902022 & APE2 & 2016-05-13 & $2016-10-11$ & 217 & 214 & 101 & 0.9 & 1.4 \\
\hline
\end{tabular}

The WMO number of missions, float name, starting and ending dates of the missions, total number of observation cycles, number of quality controlled cycles, median parking pressure, estimated median speed per mission and its standard deviation.

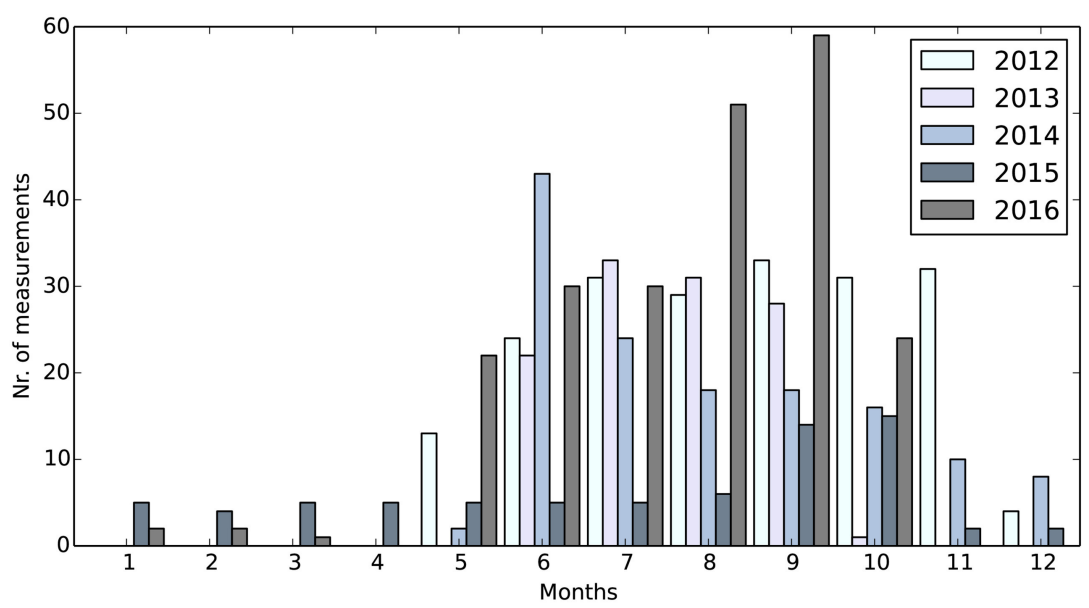

FIGURE 2 | Number of Argo cycles per month and per year in the Bothnian Sea, 2012-2016.

\subsection{Hydrodynamic Model Configuration Used for Error Analysis}

For comparing estimated velocities from floats and analyzing surface drift errors we used a 2 nautical mile set-up of the NEMO 3D ocean model (V3.6) covering the Baltic Sea and North Sea area. We ran the model for the year 2014. This set-up was documented and validated for mixing in Westerlund and Tuomi (2016) and for the currents in Westerlund et al. (2018) and is based on the NEMO Nordic configuration by Hordoir et al. (2013, 2015).

The vertical resolution of this set-up starts from $3 \mathrm{~m}$ on the surface, and increases with depth. The temporal resolution of the model is $15 \mathrm{~min}$ and the values are saved as 1 day averages. The bathymetry of the set-up was updated to the latest version of the NEMO Nordic bathymetry. River run-offs and precipitation fields were climatological. We used forecasts 


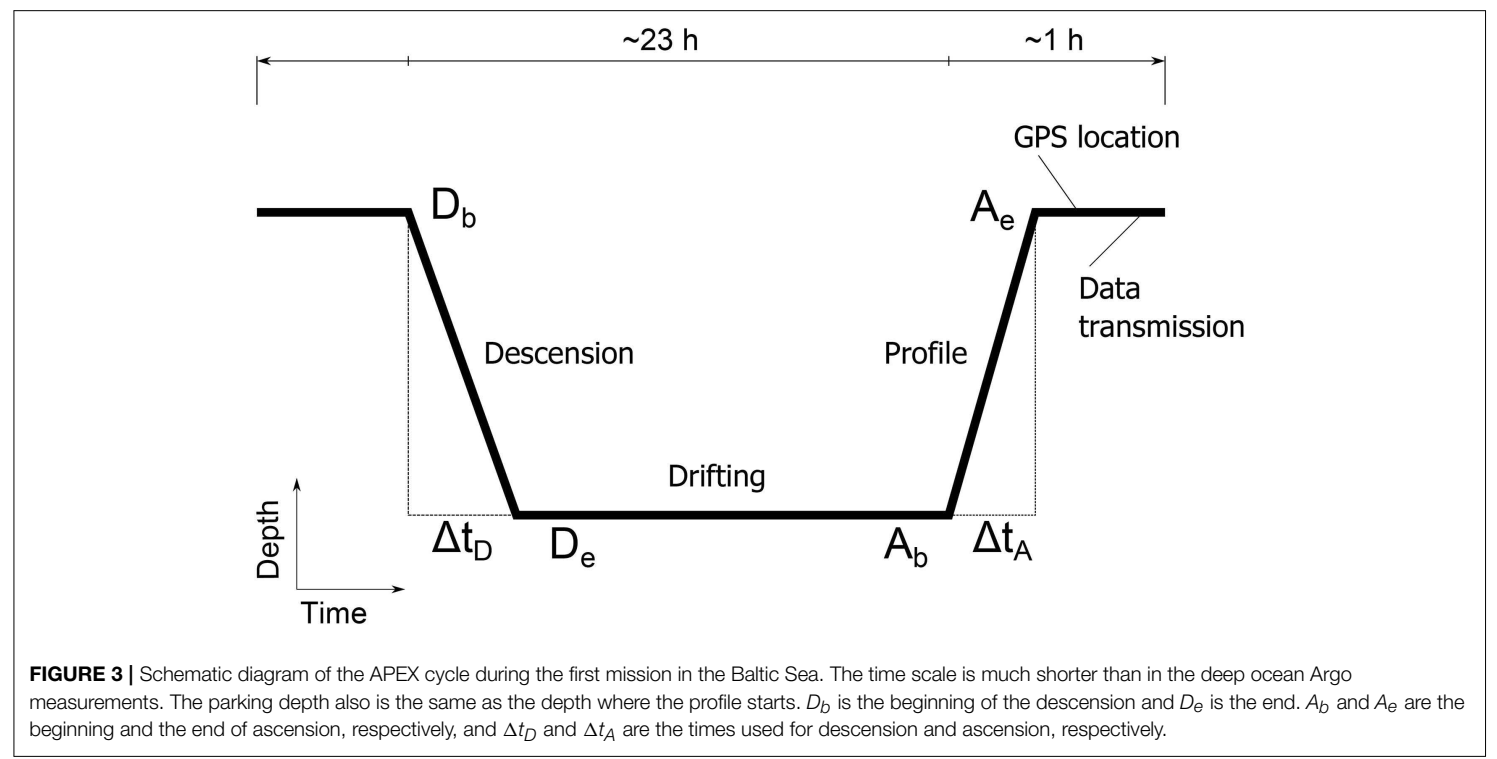

from the FMI numerical weather prediction system HIRLAM (HIRLAM-B, 2015) as forcing. Forcing was read into the NEMO run with the CORE bulk formulae (Large and Yeager, 2004).

\section{RESULTS}

We divided our analysis of deep-water currents in two sections. First we wanted to get an overall impression of the deep currents and their statistics in the Bothnian Sea in general and analyze the extreme velocities with results from a hydrodynamic model. The second topic was to analyze specifically the deep flow in the Bothnian Sea deep, which is the deepest trench along the basin, and the flow persistence there.

\subsection{Measurements and Current}

\section{Estimations in the Bothnian Sea in General}

In the Bothnian Sea the floats median diving pressure was $93 \mathrm{dbar}$ and median cycle length was $24 \mathrm{~h}$, varying from around $2 \mathrm{~h}$ to 7 days. Diving pressures were chosen so, that the estimated distance from bottom remained roughly 30 $\mathrm{m}$ in the first two missions A (6901901) and B (6902013) (Figure 1) and $10 \mathrm{~m}$ in the rest of the missions, based on known topography. For further description of the bottom distance see (Haavisto et al., 2018). The shortest cycles are used when the float has been deployed and recovered to ensure that the float can receive commands via satellite. The typical distance the float moved was 2 to $3 \mathrm{~km}$ per cycle and typical estimated speed around $2 \mathrm{~cm} / \mathrm{s}$ (Table 2), which has been considered to be typical residual speed in the deep waters. Seventy-five percent of the estimated velocities were under $3.5 \mathrm{~cm} / \mathrm{s}$. High velocities over $10 \mathrm{~cm} / \mathrm{s}$ were very rare, only $3 \%$ of the cases and were only observed during the first mission at a fairly shallow depth, median $47 \mathrm{dbars}$. The highest estimated speed was $30 \mathrm{~cm} / \mathrm{s}$ toward south at $50 \mathrm{dbar}$ depth near to Finnish coast in a situation where sea level was going down in the Gulf of Bothnia. The floats' paths followed usually the expected northward going resultant current in the deep layers of the Bothnian Sea. The first mission A (6901901) had a shallower average drifting depth than the others (Figure 1)

We compared the speeds from the NEMO model to the estimated speeds in each measurement way point in the model layer that corresponded to the diving pressure of the float. The model was run from June to December 2014. The model results cannot be compared directly to speed estimations, because the time scale of events suitable to be investigated by this model is limited by the structure of the model configuration and available inputs for the model. Overall, comparison of modeled currents to observed ones always constitutes a challenge. To be able to estimate the scale of the speeds we analyzed the speed distributions from the model and observations. In two cases the speeds either modeled by NEMO or estimated from Argo trajectories represents the highest $5 \%$ of the speeds (Figure 4).

In the study period there were three occasions, where there were steady hard winds over period of several days. During all these three events the estimated maximum speeds were over $7 \mathrm{~cm} / \mathrm{s}$. On the surface, hard constant northward winds cause upwellings on the Finnish coast of the Bothnian Sea and the low pressure system tilts the water level in the basin speeding the deep currents northward. 


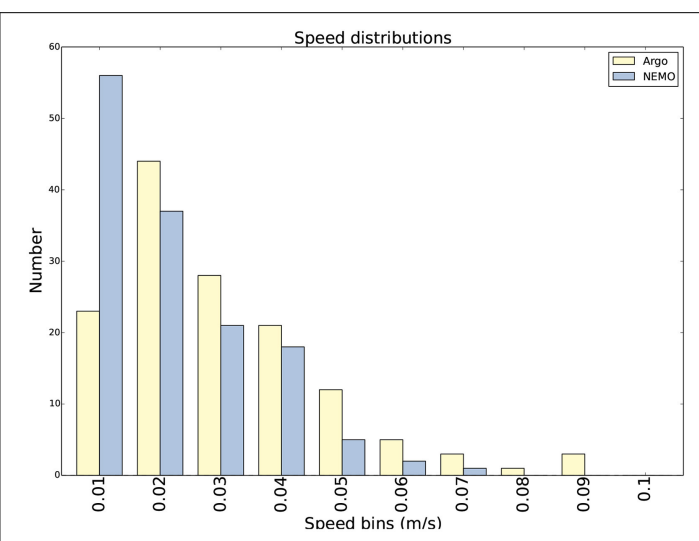

FIGURE 4 | Comparison of APEX parking pressure speed distribution versus respective NEMO speed distribution from June 2014 to December 2014.

In the beginning of June 2014, there was a steady northern wind, exceeding a daily average of $14 \mathrm{~m} / \mathrm{s}$ at four coastal weather stations along the Finnish coast on June 13. The tide gauges on Gulf of Bothnia registered a rapid water level drop during this event. The Argo float reached the speed of $8 \mathrm{~cm} / \mathrm{s}$ to $\mathrm{N}-\mathrm{N}-\mathrm{E}$ at an average pressure of $110 \mathrm{dbars}$. The cycle length was $24 \mathrm{~h}$.

On September 20-22 2014, there was a deep low pressure system passing over Sweden, which caused hard northerly winds, speeds exceeding $26 \mathrm{~m} / \mathrm{s}$ at the Swedish coastal weather stations in the Bothnian Sea. This low pressure system affected water levels throughout the Gulf of Bothnia where there was a sudden drop in water level and afterwards a very quick rise. The sea surface temperatures also dropped rapidly and we could see an upwelling event in the south-eastern coast of Bothnian Sea. This event also affected on the estimated velocity of the Argo float. The highest speed was $7.6 \mathrm{~cm} / \mathrm{s}$ to N-N-W at the average diving pressure of 117 dbars during a 48 -h cycle.

During this 7 months study period, there was one occasion where southern hard winds were dominant from October 22 to November 4 . The float moved at the fastest $8 \mathrm{~cm} / \mathrm{s}$ to N-N$\mathrm{E}$ in the diving pressure of $100 \mathrm{dbars}$. This is probably due to weakened stratification, which allows the wind to affect deeper layers than in the summer time when the water column is heavily stratified and wind effect is limited on the mixed layer. The Ekman transport has an effect on the right hand direction from the wind direction.

We may argue that both estimations show exceptionally high speeds during these events and our current estimation from the float trajectories is valid. On the last occasion the wind direction was southward and the model could not show a clear signal of higher current speeds. This could be due to issues in weather forcing and the fact that the routes of the low pressure cells may not be described exactly by the weather models, the poorly known bathymetry in the area or the model's inadequacies to produce correct stratification in the autumn.

\subsection{Measurements and Current Estimations in the Bothnian Sea Deep}

The Bothnian Sea Deep is a passage for deep water (Figure 5). Our datasets have 257 cycles from this deep. On average, the buoys drifted at 106 dbar pressure, while the maximum diving pressure was $126 \mathrm{dbar}$. The minimum pressure of $51 \mathrm{dbar}$ was reached while deployed in June 2013. The shallow parking pressure was set to avoid bottom contact during the first dive (Siiriä in submitted). The median cycle time was $24 \mathrm{~h}$. When ice avoidance was tested, the cycle time was as long as 7 days.

On average, the speed estimated from float movement was $2 \mathrm{~cm} / \mathrm{s}$, while the temporary maximum was $13 \mathrm{~cm} / \mathrm{s}$. The main directions of the currents were along the north-south axis, with the major part of observations showing northward movement. The $\mathrm{N}-\mathrm{W}$ to $\mathrm{N}$ sector covers $37 \%$ of all the observed directions, while the sector S-S-W to S-S-E sector covers around $22 \%$ of all directions (Figure 6).

The average speeds were calculated for the area (Figure 7). The diving cycles below 90 dbars were selected to represent the deep currents. We divided the area to a $3^{\prime}$ latitude $\times 6^{\prime}$ longitude grid and computed the number of observations and average current speed in each grid box. The average speed was calculated as follows:

$$
\bar{u}=\frac{1}{N} \sum_{n=1}^{N} u_{n}
$$

and

$$
\bar{v}=\frac{1}{N} \sum_{n=1}^{N} v_{n},
$$

where $\bar{u}$ and $\bar{v}$ are the average eastward and northward components of velocity, $u_{n}$ and $v_{n}$ are the respective components of the velocity in a single cycle, and $N$ is the number of cycles. Cases where there have been fewer than three measurement have been discarded. From the Equations $(1,2)$ we see that the average movement is measured as distance/time. Each dive has the same weight regardless of the diving time, as the float likely moves back and forth between the dives. Therefore a longer diving time would not indicate the actual drift direction with a higher probability than a short one.

The persistency $R$ of the current was also calculated by dividing the mean vector speed by the average scalar speed as presented by Palmén (1930)

$$
R=\frac{\sqrt{\bar{u}^{2}+\bar{v}^{2}}}{\frac{1}{N} \sum \sqrt{u_{n}^{2}+v_{n}^{2}}}
$$

Most of the averaged velocities have a a stronger northward component in the area, even though the averaged velocities are fairly small. Only the south-west corner of the studied area appears to have a stronger southward component.

We analyzed also the persistence of the flows in different grid boxes. In this study the persistence varied between 17 and $96 \%$ per cell in the grid boxes that had over 8 measurements (i.e., the float had measured the averaged currents a week or longer). In 


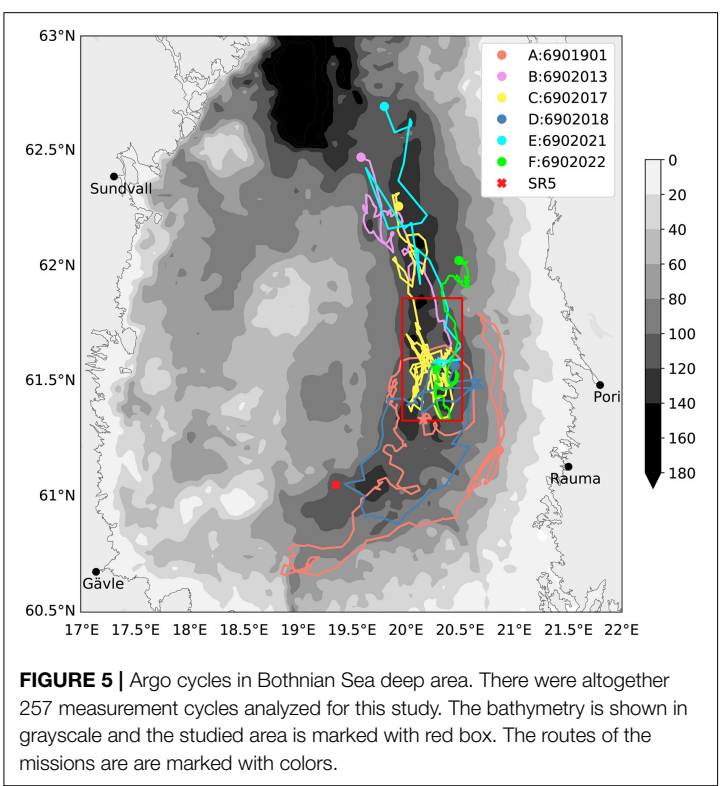

common place, the measurement per grid box are consecutive so it is possible that synoptic scale weather phenomena is one explanatory factor for persistent current. Within this method we are able to study effects of the synoptic scale weather effects to the Bothnian Sea.

In the southern part of the study area the persistence is in general fairly small and the directions of the estimated current changes quite often. However, in the middle part of the area the currents are fairly persistently flowing toward north. This is probably partly due to the directing effect of the bottom bathymetry.

\subsection{Estimating Possible Source of Errors}

Katsumata and Yoshinari (2010) have analyzed the possible sources of errors in measurement in Argo drifting. These are positioning errors, internal clock drift, and unknown surface drift before submerging and after surfacing. In this paper, we took a deeper look on surface drift because unlike the other sources of error, it is not as randomly distributed as the other errors. It is possibly the biggest source of error due to the fact that floats in the Bothnian Sea spend a fairly long portion of their mission time on the surface compared to Argos in the ocean.

The distance drifted needs to be estimated from a model or by estimating the velocity shear in the upper water column (Lebedev et al., 2007). In this study we have estimated the scale of the surface drift from the NEMO implementation in FMI. For this study, we analyzed the year 2014 from the model and observations and estimated the scale of the surface drift by calculating the drifted distance from the model at the surfacing point for each cycle. To avoid excessive error from surface drifting, we removed the measurements that stayed in the surface

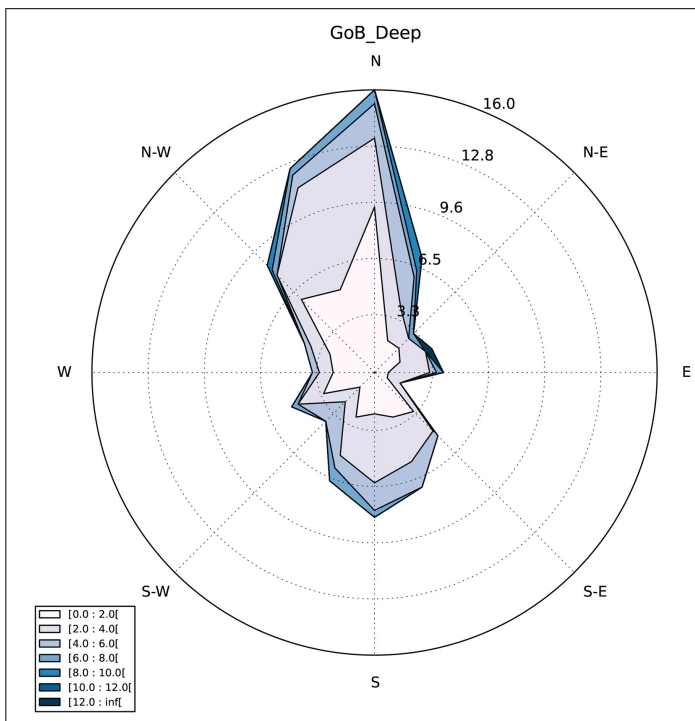

FIGURE 6 | Velocity distribution of the Apex missions in the Gulf of Bothnia Deep. The colors show the estimated speed $(\mathrm{cm} / \mathrm{s})$ and the curves show the percentage of the measurements in different directions.

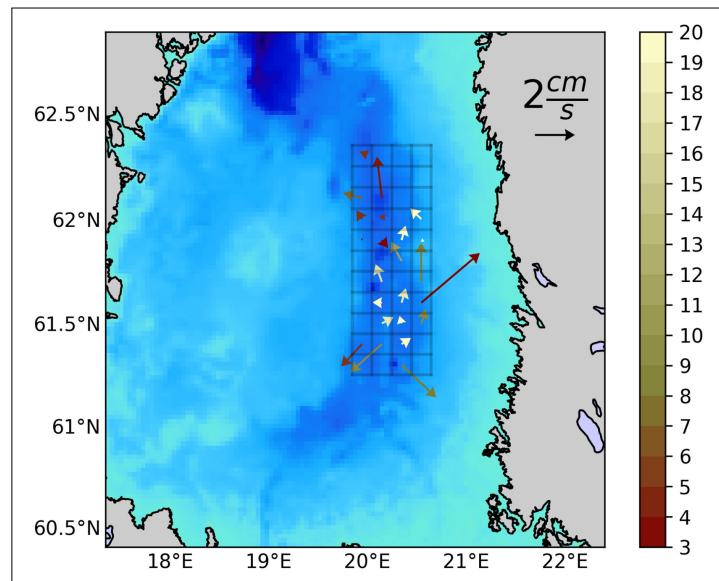

FIGURE 7 | Average Argo velocities for the drifting depth (>90 dbar) in the Bothnian Sea Deep. The length of the arrow indicates the average speed, and the color indicates the number of observations in a grid box. The lighter the color, the more observations.

layer ( $<20 \mathrm{dbars})$, where wind has a strong effect on the float movements.

In the depth range of the Bothnian Sea Deep, roughly $100 \mathrm{~m}$, the Argo floats take on average $15 \mathrm{~min}$ to reach the parking depth. In general, the speed goal for descending and ascending is $8 \mathrm{~cm} / \mathrm{s}$. The exact speed cannot be determined because the first pressure 
check is done $15 \mathrm{~min}$ after the diving procedure starts. In that time the float has usually reached the target depth.

In this study the surface drift time was around 50 min varying from 25 to 166 min depending on how quickly the floats gets the GPS position and how quickly it succeeds in getting the data connection. Another factor that affects the surface drift time is the depth of the profile and hence the amount of data to be sent. The float drifts an unknown distance while ascending, descending and while at the surface, since it reports its location only once per cycle, just before diving.

From the pressure data we assumed that the median amount of time spent in parking pressure was $95 \%$ of the total cycle time varying from 90 to $99 \%$ from mission to mission. The median value of surface drift time was $2.8 \%$ of the cycle, varying from 1 to $4 \%$ from mission to mission. The standard deviation for park time is $6 \%$ and for surface drift $3.4 \%$. The rest of the cycle is descending $\left(\Delta t_{D}\right)$ and ascending $\left(\Delta t_{A}\right)$ (Figure 3).

We were able to evaluate the drifting speed on surface in few cases, as the floats stay on surface for few hours, before recovery transmitting their location roughly once in $10 \mathrm{~min}$. These occasions gave average surface drifting speed of $9 \mathrm{~cm} / \mathrm{s}$ (lowest $3.2 \mathrm{~cm} / \mathrm{s}$, highest $15.5 \mathrm{~cm} / \mathrm{s}$ ). We also estimated the surface drift from model run of the year 2014. On every cycle the float surface time was multiplied by the model surface velocities. This gives us the rough estimation of the scale of surface drift and cannot be understood as the exact drift due to the limitations of the hydrodynamic model. The median value with this method was around $100 \mathrm{~m}$ per cycle and maximum $540 \mathrm{~m}$. In this estimation the median value for the distance traveled on the surface is $5 \%$. In comparison, the size of float's internal GPS sensor error is less than $15 \mathrm{~m}$. One must notice that most of the surface drift values are beyond the resolution of current regional 3D models.

\section{DISCUSSION}

Finnish Meteorological Institute has used Argo floats in hydrographic monitoring of the Bothnian Sea for over 6 years. The floats have measured hundreds of profiles in all seasons and we have got lots of new data from the open sea conditions and physics of the Bothnian Sea. Alongside the hydrographic data we have collected a unique dataset of over 700 estimates of the drifting velocity of the floats in their parking depths. We have analyzed those velocity estimates and their uncertainties to see if they are useful and give added value to the monitoring program.

In our measuring strategy the floats stay at maximum pressure and measure the profile from there to the surface. The pressure is defined according to the estimated topography of the area where the float is. Thus the parking depth should represent the deepest layer of the area and drift there the deep currents. The average parking pressure of our whole data set was $90 \mathrm{dbars}$, but there were differences from mission to mission. In the first two missions the average parking pressure was around 70 dbars, but later on we kept the floats deeper, at more than 95 dbars, even up to 113 dbars pressure.

It should be noted that the observation strategy was not specifically planned for measuring the drift. Thus the time step between observations varies a lot, from a few hours to several days. However, In half of the cases the time step was around one day and in $16 \%$ of the cases half a day, which both are much shorter than time steps in conventional Argo float measurements.

The aim of this study was to analyse how well these measurements describe the deep water currents and what kind of uncertainties remains. Therefore we compared our results to the earlier studies in the area.

As shown in the introduction and description of the Bothnian Sea, the general circulation of the sea was described already in the early 1900's. Those descriptions were based on current measurements from research ship and light ships. Some decades later Palosuo (1964) studied the hydrography of the Bothnian Sea and found the cyclonic circulation in the upper layers $(15-40 \mathrm{~m})$.

Strong efforts were put to the Gulf of Bothnia in its specific study year 1991. In that context Alenius (1993) concluded that the $60 \mathrm{~m}$ currents in the southern Bothnian Sea, on station SR5, were more variable in direction and speed than on coastal stations being less than $20 \mathrm{~cm} / \mathrm{s}$ with northward currents dominating. Current measurements were done in 1990 and 1991 with Aanderaa RCM-4 and RCM-7 current meters at station SR5 (61.0520N, 19.3555E) (Figure 1) in the central southern Bothnian Sea (Alenius, 1993) for several months in both years with 10 and 15 min time steps. The data consists of over 33,000 individual observations from $113 \mathrm{~m}$ depth. In almost half of the observations, the current speed was below the threshold speed, $1.1 \mathrm{~cm} / \mathrm{s}$, of the current meters, which makes impossible to estimate the true average speed there. The mean current speed from data including the threshold speed was $4.5 \mathrm{~cm} / \mathrm{s}$. There exists also ADCP data and ship measurements from the Bothnian Sea Hietala et al. (2007).

We detected a northward resultant current in the Bothnian Sea deep in accordance with the earlier studies. Our results of current direction and speed were in line with present knowledge in that area. Analysis of the persistence of the deep currents showed that there were some areas where the flow was fairly persistent and the flow toward the north was notably constant.

This is partly due to the topographical steering of the deep area. In the literature we could find values for persistence of the surface currents in the area, which are typically between 20 and $40 \%$ (Leppäranta and Myrberg, 2009) or 20 and 90\% (Witting, 1912). In general, the deep currents are more persistent than upper layer currents in the open sea.

Our analysis of persistence for the currents shows values that are in accordance of the values found in early literature. The limited number of drift estimates filter out possible short time scale motions which makes difficult to generalize our persistence results. Further studies are needed to analyze the persistence on the longer time scales.

The overall properties of the currents estimated from Argo float trajectories are similar enough to the earlier studies to give confidence that Argo data is useful in describing at least the net transport of the deep waters in the Bothnian Sea. However, because the floats leave the parking depth water mass when they measure the vertical profile, the water mass where they return after the profile measurement and consequent surface drift, is not exactly the same than where they were before. How this affects the results remains to be studied. 
Argo float drift is not the best method to describe extreme velocity cases, though such cases may be important in shaping the underwater environment. The strong currents feed energy for the mixing processes, shape the bottom and move matter. The suspension and resuspension caused by friction and turbulence is an important factor in nutrient cycling. These extreme deep currents are difficult to study with hydrodynamic models because of their small scale. With Argo float data, we may still get more accurate information about the strength of the currents.

One major source of error in the deep current estimate is the surface drift of the float, when it determines its position and sends the data and receives instructions. The float can also drift horizontally during the ascent and descent from and to the parking depth. This may especially be the case in measurements in the shallow sea and short time steps between the profiles. For using the floats specifically for deep flow measurements, one should optimize the measurement interval so that our resolution is fine enough to be in the scale of the deep water phenomena to be studied and large enough in comparison to the surface drift so that the error does not overwhelm the whole estimation.

We used surface drift estimates from numerical model and data from the recovery of the floats in our error estimation. During the recovery the float records its position with 10-15 $\mathrm{min}$ intervals and sends typically several positions values during the drift at the surface. This is the best estimate of the float's surface drift, for the float behaves similarly during the mission.

The data collected in the recovery includes only fairly calm wind situations so it would be beneficial to measure the surface drift also in windy situations to achieve the speed range of the wind driven drift.

We are still on the way of studying other methods to estimate the surface drift of our floats and how it really affects to the estimates of deep currents.

\section{CONCLUSIONS}

Our aim was to study how well Argo float measurements describe the deep water currents and what kind of uncertainties remains. As the drift of the float follows the water mass, we conclude that we have caught the water mass movements of the deep water in the Bothnian Sea, which is essential for the long-term environmental conditions in the basin.

Argo floats have been used for years in the ocean monitoring for their reliability, affordability, weather independence, and realtime data sending after profiling.In this study we have shown that they are usable also for current estimation in the very shallow semi-enclosed sea as the Baltic Sea.

In shallow waters the Argo floats have still limitations, some of which may be resolved in the future. The strength and weakness of Argos is that they are not stationary. Larger areas can be covered with the floats, but the prevailing currents steer their movement mostly. We can steer the floats in some degree by adjusting the cycle length and the diving pressure or by keeping the float at the surface when it drifts to the desired direction there, but the true destination remains still dependent on the currents and winds.
For shallow water the lack of altimeter in the float forces to define the parking pressure by relying on the existing bathymetric data, which is not always accurately known. Thus the very nearbottom currents remain out of sight of the floats.

Even though the floats are used for routine monitoring, their capacity allows to react to differing conditions and increase the observing frequency when needed. Coordinated use of Argo floats and other autonomous vehicles, like gliders, increase the monitoring and research possibilities even further.

In the future with better GPS positioning at the surface we can reduce the error in deep water flow estimates and we can get surface drift estimates, too. With these features we may give new use for the Argo data in monitoring and this comes without any extra costs. Argo floats have become an integral part of the Baltic Sea monitoring and they serve scientific research, too.

The next step is the optimizing of the number of floats as well as their measuring frequency as already studied in the Black Sea (Grayek et al., 2015). Optimization depends on many factors, such as whether studying long-term changes in the current field or quick changes caused by low pressure systems.

In order to be able to detect mesoscale phenomena, we need to have measurements in time interval of days and spatial scale of kilometres, which can be easily achieved by Argo measurements as shown in our study. These mesoscale phenomena are for example eddies, lenses of different water masses and effects of mixing in the water column during the storms. These measurements can be used as well in analysing the present conditions as well as in developing the hydrodynamic models, forecasts, and scenario studies for the future.

We may also use the Argo data to estimate the age of the water in the basin, as is done with models by Myrberg and Andrejev (2006) Also, the data may be used to study, for example, the salinity changes and oxygen conditions under the halocline and the accumulation of environmentally harmful substances in the deep areas.

By combining Argo data with other in-situ measurements and hydrodynamic model results we could get a more complete picture of the water movements in the Gulf of Bothnia. Argos have been used already before in the ocean to characterize the interplay of the different water masses and currents (e.g., Gasparin et al., 2011).

These measurements could also be assimilated into forecasting systems with hydrodynamical models to gain a better understanding of the dynamics in the deep areas (e.g., Taillandier et al., 2010). The better we understand the connections between the sea and the atmosphere, the better we can estimate the effects of the changing climate on the biotic and abiotic environment

\section{AUTHOR CONTRIBUTIONS}

All authors contributed to planning of this study. PR wrote the first draft and did largely the analyses for the observations and model results. S-MS and NH contributed on analyses and illustrations. $\mathrm{PR}, \mathrm{NH}$, and $\mathrm{PA}$ did literature and background research. AW did the 3D modeling for this study and contributed on analyzing the model results. TP participated significantly on 
acquisition of the data and evaluation of the measurements with PR and NH. All authors wrote sections for this manuscript and revised and approved the final version.

\section{ACKNOWLEDGMENTS}

These data were collected and made freely available by the International Argo Program and the national programs

\section{REFERENCES}

Alenius, P. (1993). "Finnish Eulerian current measurements," in The Gulf of Bothnia Year 1991. Physical Transport Experiments, SMHI Reports Oceanography (Norrköping: Swedish Meteorological and Hydrological Institute), 30-40.

Argo (2000). Argo float data and metadata from global data assembly centre (Argo GDAC). SEANOE. doi: 10.17882/42182

Backer, H. and Frias, M. (2013). Planning the Bothnian Sea-Key Findings of the Plan Bothnia project. Plan Bothnia.

Bulczak, A., Rak, D., Schmidt, B., and Beldowski, J. (2016). Observations of near-bottom currents in Bornholm Basin, Slupsk Furrow and Gdansk Deep. Deep Sea Res. II Top. Stud. Oceanogr. 128, 96-113. doi: 10.1016/j.dsr2.2015. 02.021

Carval, T., Keeley, B., Takatsuki, Y., Yoshida, T., Loch, S., Schmid, C., et al. (2015). ARGO User's Manual, Version 3.2. (Ifremer). doi: 10.13155/29825

Fonselius, S., and Valderrama, J. (2003). One hundred years of hydrographic measurements in the Baltic Sea. J. Sea Res. 49, 229-241. doi: 10.1016/S1385-1101(03)00035-2

Fonselius, S. H. (1996). Västerhavets Och Östersjöns Oceanografi. Norrköping: SMHI.

Gasparin, F., Ganachaud, A., and Maes, C. (2011). A western boundary current east of New Caledonia: observed characteristics. Deep Sea Res. I Oceanogr. Res. Pap. 58, 956-969. doi: 10.1016/j.dsr.2011.05.007

Grayek, S., Stanev, E. V., and Schulz-Stellenfleth, J. (2015). Assessment of the Black Sea observing system. A focus on 2005-2012 Argo campaigns. Ocean Dyn. 65, 1665-1684. doi: 10.1007/s10236-015-0889-8

Haapala, J., and Alenius, P. (1994). Temperature and salinity statistics for the northern Baltic Sea 1961-1990. Finn. Mar. Res. 262, 51-121.

Haavisto, N., Tuomi, L., Roiha, P., Siiriä, S.-M., Alenius, P., and Purokoski, T. (2018). Argo floats as a novel part of the monitoring the hydrography of the Bothnian Sea. Front. Mar. Sci. 5:324. doi: 10.3389/fmars.2018.00324

Hela, I. (1958). A hydrographical survey of the waters in the Åland Sea. Geophysica $6,219-242$.

Hietala, R., Lundberg, P., and Nilsson, J. A. (2007). A note on the deep-water inflow to the Bothnian Sea. J. Mar. Syst. 1, 255-264. doi: 10.1016/j.jmarsys.2006.12.004

HIRLAM-B (2015). System Documentation. Technical report, HIRLAM Consortium.

Hordoir, R., Axell, L., Löptien, U., and Dietze, H. (2015). Influence of sea level rise on the dynamics of salt inflows in the Baltic Sea. J. Geophys. Res. 120, 6653-6668. doi: 10.1002/2014JC010642

Hordoir, R., Dieterich, C., Basu, C., Dietze, H., and Meier, H. (2013). Freshwater outflow of the Baltic Sea and transport in the Norwegian current: a statistical correlation analysis based on a numerical experiment. Contin. Shelf Res. 64, 1-9. doi: 10.1016/j.csr.2013.05.006

Kahru, M., Håkansson, B., and Rud, O. (1995). Distributions of the sea-surface temperature fronts in the Baltic Sea as derived from satellite imagery. Contin. Shelf Res. 15, 663-679.

Katsumata, K., and Yoshinari, H. (2010). Uncertainties in global mapping of Argo drift data at the parking level. J. Oceanogr. 66, 553-569. doi: 10.1007/s10872-010-0046-4

Korotaev, G., Oguz, T., and Riser, S. (2006). Intermediate and deep currents of the Black Sea obtained from autonomous profiling floats. Deep Sea Res. II Top. Stud. Oceanogr. 53, 1901-1910. doi: 10.1016/j.dsr2.2006.04.017 that contribute to it (http://www.argo.ucsd.edu, http://argo. jcommops.org). The Argo Program is part of the Global Ocean Observing System. The authors want to thank Laura Tuomi for enabling and commenting this work and Eemeli Aro for technical support in the early phases of the Baltic Sea Argo monitoring. This work has been partly supported by the Strategic Research Council at the Academy of Finland, project SmartSea (grant number 292 985).

Kuosa, H., Fleming-Lehtinen, V., Lehtinen, S., Lehtiniemi, M., Nygård, H., Raateoja, M., et al. (2017). A retrospective view of the development of the Gulf of Bothnia ecosystem. J. Mar. Syst. 167, 78-92. doi: 10.1016/j.jmarsys.2016.11.020

Large, W. G., and Yeager, S. G. (2004). Diurnal to Decadal Global Forcing for Ocean and Sea-Ice Models: the Data Sets and Flux Climatologies. NCAR Technical Note, NCAR/TN-460+STR, CGD Division of the National Center for Atmospheric Research.

Lavender, K. L., Owens, W. B., and Davis, R. E. (2005). The mid-depth circulation of the subpolar North Atlantic Ocean as measured by subsurface floats. Deep Sea Res. I Oceanogr. Res. Pap. 52, 767-785. doi: 10.1016/j.dsr.2004.12.007

Le Traon, P. Y. (2013). From satellite altimetry to Argo and operational oceanography: three revolutions in oceanography. Ocean Sci. 9, 901-915. doi: 10.5194/os-9-901-2013

Lebedev, K. V., Yoshinari, H., Maximenko, N. A., and Hacker, P. W. (2007) Yomaha'07: Velocity Data Assessed from Trajectories of Argo Floats at Parking Level and at the Sea Surface. International Pacific Research Center (IPRC) Technical Note.

Leppäranta, M., and Myrberg, K. (2009). Physical Oceanography of the Baltic Sea. Berlin: Springer. doi: 10.1007/978-3-540-79703-6

Marmefelt, E., and Omstedt, A. (1993). Deep water properties in the Gulf of Bothnia. Contin. Shelf Res. 13, 169-187.

Meier, H. E. M., Feistel, R., Piechura, J., Arneborg, L., Burchard, H., Fiekas, V., et al. (2006). Ventilation of the Baltic Sea deep water: a brief review of present knowledge from observations and models. Oceanologia 48 133-164.

Menna, M., and Poulain, P. M. (2010). Mediterranean intermediate circulation estimated from Argo data in 2003-2010. Ocean Sci. 6, 331-343. doi: 10.5194/os-6-331-2010

Murthy, R., Håkansson, B., and Alenius, P. (1993). The Gulf of Bothnia Year 1991 Physical Transport Experiments. Technical Report 15, SMHI, Norrköping.

Myrberg, K., and Andrejev, O. (2006). Modelling of the circulation, water exchange and water age properties of the Gulf of Bothnia. Oceanologia 48S, $55-74$.

Palmén, E. (1930). Untersuchungen über die Strömungen in den Finnland umgebenden Meeren. Soc. Sci. Fenn. Comm. Phys. Math. 12, 1-82.

Palosuo, E. (1964). A description of the seasonal variations of water exchange between the Baltic Proper and the Gulf of Bothnia. Merentutkimuslaitoksen Julkaisu 215 32, 1-32.

Park, J. J., Kim, K., King, B. A., and Riser, S. C. (2005). An advanced method to estimate deep currents from profiling floats. J. Atmos. Ocean. Technol. 22 1294-1304 doi: 10.1175/JTECH1748.1

Purokoski, T., Aro, E., and Nummelin, A. (2013). First long-term deployment of Argo float in Baltic Sea Argo's inaugural operation in shallow, low-salinity water. Sea Technol. 54, 41-44.

Raateoja, M. (2013). Deep-water oxygen conditions in the Bothnian Sea. Boreal Environ. Res. 18, 235-250.

Riser, S. C., Freeland, H. J., Roemmich, D., Wijffels, S., Troisi, A., Belbeoch, M., et al. (2016), Fifteen years of ocean observations with the global Argo array, Nat. Clim. Change 6, 145-153, doi: 10.1038/nclimat e2872

SMHI (1982). "Climatological ice atlas for the Baltic Sea, Kattegat, Skagerrak and lake Vänern (1963-1979)," in Swedish Meteorological and Hydrological Institute \& Institute of Marine Research, Finland. Norrköping. 
Suhhova, I., Liblik, T., Madis-Jaak, L., and Urmas, L. (2018). A descriptive analysis of the linkage between the vertical stratification and current oscillations in the Gulf of Finland. Boreal Environ. Res. 23, 83-103.

Taillandier, V., Dobricic, S., Testor, P., Pinardi, N., Griffa, A., Mortier, L., et al (2010). Integration of Argo trajectories in the Mediterranean forecasting system and impact on the regional analysis of the western Mediterranean circulation. J. Geophys. Res. Oceans 115:C03007. doi: 10.1029/2008JC005251

Uotila, J., Launiainen, J., and Vihma, T. (1996). Analysis of the surface drift currents in the Bothnian Sea. Oceanogr. Lit. Rev. 5:432.

Voet, G., Quadfasel, D., Mork, K. A., and Søiland, H. (2010). The mid-depth circulation of the Nordic Seas derived from profiling float observations. Tellus A 62, 516-529.

Westerlund, A., Tuomi, L., Alenius, P., Miettunen, E., and Vankevich, R. E. (2018). Attributing mean circulation patterns to physical phenomena in the Gulf of Finland. Oceanologia 60, 16-31. doi: 10.1016/j.oceano.2017.05.003

Westerlund, A., and Tuomi, L. (2016). Vertical temperature dynamics in the Northern Baltic Sea based on 3D modelling and data from shallowwater Argo floats. J. Mar. Syst. 158, 34-44. doi: 10.1016/j.jmarsys.2016. 01.006

Wieczorek, G. (2012). Spatiotemporal Scales of the Deep Circulation in the Eastern Gotland Basin/Baltic Sea. Ph.D. thesis.Meereswissenschaftliche Berichte
MARINE SCIENCE REPORTS No. 88 Leibniz-Institut für Ostseeforschung Warnemünde.

Witting, R. (1912). Zusammenfassende übersicht der Hydrographie des Bottnischen und Finnischen Meerbusens und der Nördlichen Ostsee. Finnländische hydrographisch-biologische Untersuchungen.

Witting, R. and Pettersson, H. (1925). Thalassologische Beobachtungen im Ålandsmeer und Schärenmeer in juli 1922 und juli 1923 Merentutkimuslaitoksen Julkaisuja 30, 1-39.

Woods, J. D. (1985). The world ocean circulation experiment. Nature 314:501.

Conflict of Interest Statement: The authors declare that the research was conducted in the absence of any commercial or financial relationships that could be construed as a potential conflict of interest.

Copyright $\odot 2018$ Roiha, Siiriä, Haavisto, Alenius, Westerlund and Purokoski. This is an open-access article distributed under the terms of the Creative Commons Attribution License (CC BY). The use, distribution or reproduction in other forums is permitted, provided the original author(s) and the copyright owner(s) are credited and that the original publication in this journal is cited, in accordance with accepted academic practice. No use, distribution or reproduction is permitted which does not comply with these terms. 


\section{Publication IV}

Petra Roiha, Antti Westerlund and Noora Haavisto. Forecasting upwelling events with monthly ensembles for the eastern coast of the Gulf of Bothnia in the Baltic Sea. Journal of Operational Oceanography, 9, 2, 115-125, 11 2016. 



\section{Forecasting upwelling events with monthly ensembles for the eastern coast of the Gulf of Bothnia in the Baltic Sea}

\author{
Petra Roiha (D), Antti Westerlund (1) and Noora Haavisto \\ Finnish Meteorological Institute, Helsinki, Finland
}

ARTICLE HISTORY

Received 25 March 2015

Accepted 10 October 2016

\section{Introduction}

The upwelling phenomenon has a strong impact on the physical and biological marine environment in the Baltic Sea. The upward flowing cool water brings nutrients to the euphotic zone (Vahtera et al. 2005) and cools the environment. It also has an effect on air temperature and potentially on rapid fog formation (Leppäranta \& Myrberg 2009), as well as on carbon dioxide cycling between the sea and the atmosphere (Löffler et al. 2012).

In an elongated, stratified basin, such as the Bothnian Sea, the principal response to constant wind along the coast is as follows: Ekman transport emerges in the surface layer in a cross direction. As a result, the sea level rises on the right-hand-side coast from the wind direction and falls on the other side's coast. Consequently, there are coastal jets produced along both coasts, which are compensated for by slow return flows from the central basin (Krauss \& Brügge 1991).

For an upwelling to emerge in the Baltic Sea, the wind event must last for at least $60 \mathrm{~h}$, and, besides this, wind direction and water column stratification play important roles (Haapala 1994). In the Baltic Sea, upwelling is a fairly common phenomenon, for example, on the coast of the Gulf of Finland, the Gulf of Bothnia and the east coast of Gotland island (Håkansson et al. 1996) to name but a few. Almost all strong enough wind patterns cause upwelling in some parts of the sea (Lehmann \& Myrberg 2008).

The statistical occurrences of the phenomenon have been analysed by numerical modelling, which concludes that the main areas of coastal upwelling events in the Baltic Sea are the Bothnian Sea, the northern coast of the Gulf of Finland, the west coast of the Baltic Proper, the east coast of Gotland, the east coast of the Estonian islands, the east coast of Denmark, including the Straits and areas east of Bornholm island (Myrberg \& Andrejev 2003). The statistical occurrences have also been analysed by satellite analysis, which shows similar results as the modelling study but also notes that there are pronounced upwelling events along the Polish coast as well as the Baltic east coast (Lehmann et al. 2012).

Ensemble forecasting has been since beginning of the 1990s, an important tool in many disciplines, especially in meteorology. The first ensemble predictions were produced operationally in US National Meteorological Center (Tracton \& Kalnay 1993) and European Centre for Medium-Range Weather Forecasts (ECMWF) (Palmer et al. 1993).

In general, an ensemble forecast can be produced by several methods: by using single model with different forcing (e.g. Molteni et al. 1996), by combining singlemodel ensembles as multi-model multi-analysis ensembles (e.g. Mylne et al. 2002) or by using several models as a poor-man's ensemble predicted system (EPS) (e.g. Ebert 2001).

In the Baltic Sea, the ensemble forecasts are widely used in climatological studies (e.g. Meier et al. 2011), where the time span reaches up to decades. The ensemble forecasting is also used in operational oceanography, especially with medium-range time scales. The state-of-the-art 
operational ensemble forecasting and warning systems in North Sea and Baltic Sea produces medium-range forecasts with lead times of 48,60 or $72 \mathrm{~h}$ (Alfieri et al. 2012; Golbeck et al. 2015).

The deterioration of model forecasts with time is a well-known issue in weather forecasting, where the reliable forecast range today is about a week depending on the parameter and location (Bauer et al. 2015). However, the heat capacity and density of water are much higher than those of air and, because of this, the persistence of some phenomena in the oceans is typically longer than in the atmosphere, which suggests better predictability for these events. The internal weather of the sea, for example, on the oceanic mesoscale, includes mainly phenomena that occur on temporal scales ranging from days to months, and on spatial scales ranging from kilometres to hundreds of kilometres (Lermusiaux 2006).

There are several ways to analyse an ensemble. Variables can be studied by, for example, calculating the ensemble mean, which provides an estimate of the probabilistic expectation forecast. The ensemble can also be divided into smaller sub-ensembles to make alternative forecasts (Brankovic \& Palmer 1997) and even individual members can be used for prediction purposes. Ensembles can be used as a quantitative tool for risk assessment. In many applications, their potential economic value can be much higher than the value of a deterministic forecast (Richardson 2000).

In comparison with a single deterministic forecast, ensembles offer the benefit of estimates of the bias, deviation and range of the modelled variables, which may be then compared with real-life situations, and it is also possible to analyse the ensembles and see which forecasts have a low predictive value (Buizza 1997). It is important to know not only the numerical value of the forecast variable but also to get information on the reliability of the prediction (Leutbecher \& Palmer 2008). The validity of one ensemble forecast tells very little of the performance of the forecasting system in general (Jolliffe \& Stephenson 2003). Therefore, it is necessary to use a statistical approach and to choose the specific methods that best suit the task at hand.

In this study, a probability-based forecast is analysed, including an in-depth look at the monthly ensemble prediction system of sea surface temperature (SST) and its performance. The special conditions of the northern parts of the Baltic Sea are considered, and a case study to show the possibilities and challenges in interpreting ensemble forecasts of upwelling events is examined. A statistical study to deepen the understanding of the system is presented.

In this study, methods of ensemble forecasting are developed and applied to gain information of useful limits of predictability of the upwelling phenomena in the Gulf of Bothnia in the Baltic Sea.

\section{Materials and methods}

\section{Model configuration and ensemble production}

We used Baleco, the operational three-dimensional biogeochemical model of the Finnish Meteorological Institute. The model consists of a general circulation model, the MITgcm (Marshall, Adcroft, et al. 1997; Marshall, Hill, et al. 1997), and an ecological module. The model is discretised on a spherical polar grid. The grid size is $0.1^{\circ}$ in longitude and $0.2^{\circ}$ in latitude: about $11.1 \mathrm{~km}$, or six nautical miles. The model domain consists of 120 grid cells in the latitudinal direction, 108 grid cells in the longitudinal direction and 21 grid cells in the vertical direction. The south-western corner of the model domain is at $53.85^{\circ} \mathrm{N}, 8.7^{\circ} \mathrm{E}$. The vertical resolution of the model is concentrated in the euphotic zone, so that the topmost layer is $3 \mathrm{~m}$, reduced to $2 \mathrm{~m}$ for the cells touching the coast. The bottom topography is from work of Seifert and Kayser (1995). The spatial discretisation is made with a minimum filter at intervals of six nautical miles. The model appears to have a slight warm bias of approximately $0.5^{\circ} \mathrm{C}$ (Kiiltomäki 2008). For more information on the modelling system, see Roiha et al. (2010).

The ensembles were created from an unperturbed initial ocean state by running the model several times with perturbed sets of weather forcings. The unperturbed ocean state was taken from the routinely produced deterministic short-term model forecast. The weather ensembles were from the monthly forecasting system of the ECMWF, which is based on the Integrated Forecasting System atmospheric model (from cycle CY32R3V in 2008 to CY35R3 in 2009). They were created with the singular vector method (Molteni et al. 1996). The weather parameters used as external forcing for the ocean model were 6-hourly winds at $10 \mathrm{~m}$, temperature as well as dew point temperature at $2 \mathrm{~m}$, and 12-hourly surface solar radiation and surface thermal radiation. The wind stress is calculated by the model from the ECMWF for 10-m wind forcings. In some cases with stormy winds, the wind stress grows large in certain areas of the model domain, destabilising the system. As model stability and forecast availability are paramount for operational forecasting system, this is compensated for by restricting the stress value growth over a threshold value.

These weather ensembles consist of 50 perturbed ensemble members and an additional deterministic unperturbed control run. For the purposes of this 
study, altogether 26 of 27-day forecasts were analysed for the summer seasons of 2008 and 2009. All in all there were 1326 individual model runs. Forecasts were made at one-week intervals, the first ones starting at the beginning of June, and the last ones starting at the end of August.

\section{Verification methods}

Three methods, described below, are used to verify the distribution of the ensemble as a sample from the probability distribution function (Casati et al. 2008) and to evaluate the quality of the ensemble forecasts. These methods exploit the whole ensemble, thus giving more information on the system.

We used a rank histogram to estimate the quality of the formulation of the ensemble forecast system. The rank histogram is a graphical illustration of the spread and the bias of the forecasting system. According to reports, this method has been successfully used for both simple low-order dynamical systems as well as for general circulation models. The first version of this method was introduced by Anderson (1996). In this case, the method is proven to be applicable, but it has to be used carefully with other statistical methods as follows (Hamill 2001; Marzban et al. 2011; Wilks 2011).

In addition, we use the continuous rank probability score (CRPS). With this one can compare observations with the whole ensemble and estimate the absolute error between the system and reality. The CRPS method has several advantages: it is sensitive to the total range of the parameter of interest, it does not need predefined classes, it can be interpreted as an integral over all possible Brier scores and, for a deterministic forecast, it boils down to a mean absolute error (Hersbach 2000).

The third method is to look at results with the residual quartile-quartile (R-Q-Q) (Marzban et al. 2011). In this method, residuals from the model are compared with predicted values. For perfect model, this comparison produces random pattern. Any type of pattern indicates problem with model fitness or variance heterogeneity.

\section{Observations}

To analyse the modelling system and forecasts, three types of measurements were used: (1) SST from Northern Baltic Wave buoy, (2) SST from tide gauges along the shore of the Gulf of Bothnia (Figure 1) and (3) SST from satellite measurements.

The buoy measurements were taken automatically every half an hour and averaged over $24 \mathrm{~h}$. These observations were used to analyse the overall performance of the ensemble forecasting system. Tide gauge measurements along the shore of the Gulf of Bothnia from eight measurement sites were used (Figure 1). The temperature was measured every $10 \mathrm{~min}$ and for the upwelling analysis, the data were averaged over $24 \mathrm{~h}$. In addition, satellite SST observations were used to identify the upwelling events. This dataset was based on data from the National Oceanic and Atmospheric Administration (NOAA) Advanced Very High Resolution Radiometer (AVHRR) satellite. Image was processed using a split window method and cloud detection algorithm at SYKE (Finnish Environment Institute) (SYKE 2016).

In this work, upwelling events in the Gulf of Bothnia are considered for the years 2008 and 2009. Tide gauge and satellite observations are used to verify the upwelling events. Only events where the phenomenon was detectable both in tide gauge data and satellite observations are accepted to ensure that the upwelling event is sizeable enough to be able to be seen in the forecasts. For the year 2009, there were no upwelling events which could have been detected by both observation methods, mostly due to the cloudiness in satellite pictures.

The upwelling phenomenon is illustrated with EPS plumes as well as violin plots (Hintze \& Nelson 1998), which show the change in SST per day. Violin plots are a developed version of more commonly used boxplots. Their advantage is that the violin plot is more informative showing the full distribution of the data. This enables detection of sub-ensembles, when the ensemble distribution is multi-modal, i.e. has more than one peak.

\section{Results}

\section{Upwelling events and the accuracy of the forecasts}

During an upwelling event, the typical change in surface temperature is from 1 to $5^{\circ} \mathrm{C} /$ day (Lehmann \& Myrberg 2008). Accordingly, $1^{\circ} \mathrm{C} /$ day was used as a threshold lower limit for an upwelling event.

In forecasting the upwelling events, the interest is mainly on the timing in order to be able to, for example, estimate the possibility of fogginess in a coastal area. This monthly scale prediction could be then refined by shorter-term forecasts. In this work, the forecast was evaluated as successful if the cooling period started during the upwelling period in the tide gauge and satellite observations.

Altogether there were 13 measured upwelling events, which could be detected on one or more from eight tide gauges during the study period. The forecasts were divided into three categories: forecasts of less than 7 


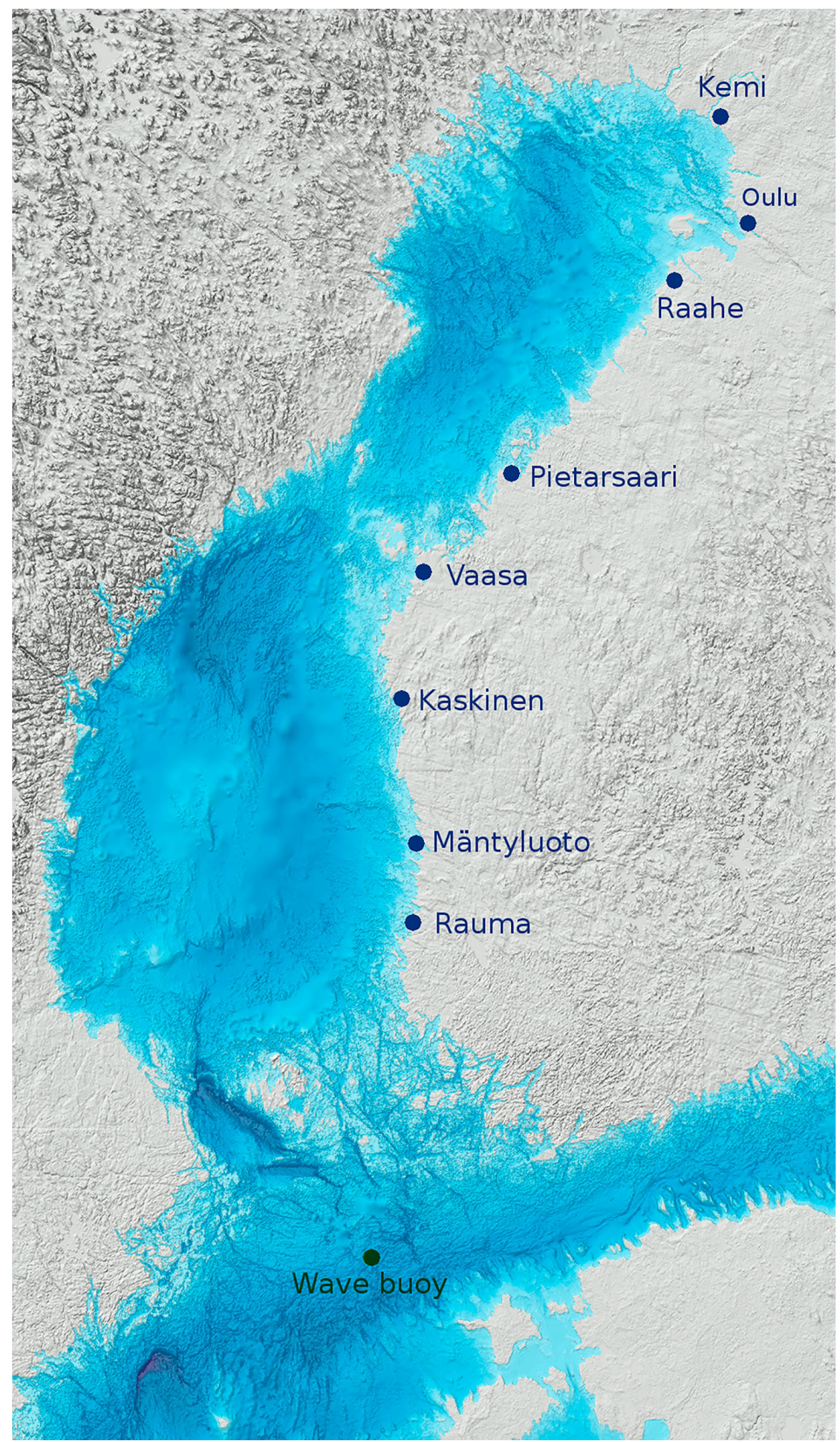

Figure 1. Bottom topography (BSHC 2013) for the Gulf of Bothnia.

Note: The tide gauge locations and wave buoy $\left(59.25^{\circ} \mathrm{N}, 21.00^{\circ} \mathrm{E}\right)$ are marked with dots.

days, forecasts from 7 to 14 days and forecasts for over 14 days. The shortest forecast period predicted 11 upwelling events, the second 6 and the longest 2 . The probability of detection value, which means fraction of observed events that is forecasted correctly, was $84.6 \%$ for the shortest forecast, $46.2 \%$ for the two-week forecast and $15.4 \%$ for the more-than-two-week forecast. The false alarm rate, i.e. fraction of false alarms from all forecasted 


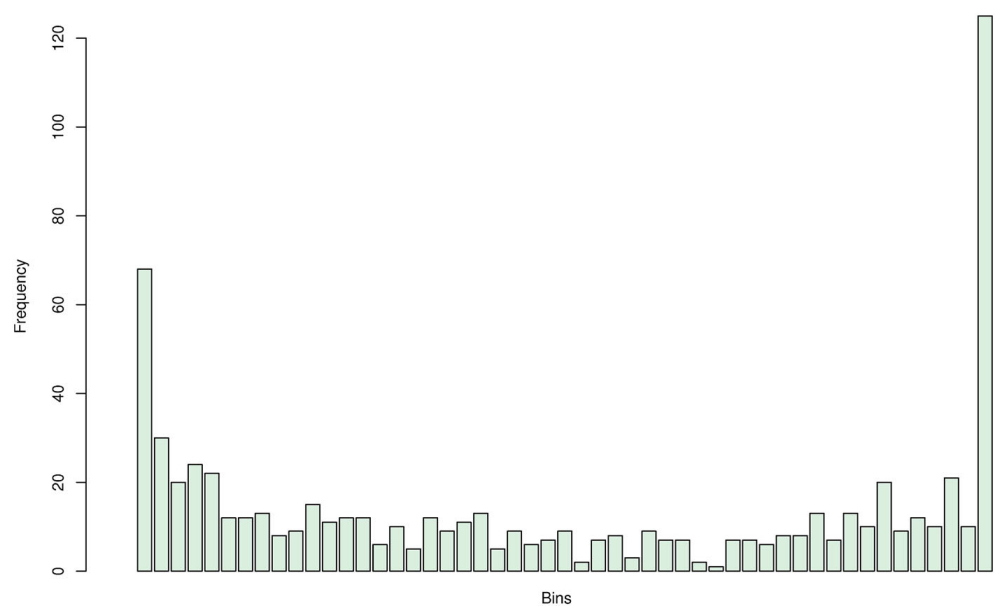

Figure 2. Rank histogram for 26 ensemble forecasts for the summers 2008 and 2009, observations from the Northern Baltic buoy.

events, was $15.4 \%$ for the less-than-a-week forecast, $68.4 \%$ for the two-week forecast and $84.6 \%$ for the longest forecast.

\section{Verification of the forecasting system}

A rank histogram combined from monthly ensemble forecasts for 2008 and 2009 shows that the observations tend to fall in lower bins than statistically expected (Figure 2). This indicates that the system is slightly biased. The rank histogram also shows that the spread of the ensemble does not cover enough of the future possibilities, and many observations tend to fall outside the forecast plume. In this study, lowest and highest bins of the rank histogram are overrepresented.

The CRPS (Figure 3) shows that the error between the observation and the ensemble grows as the span of the forecast grows. On average, the error between the forecast and the observation tends to grow by around 0.01 degrees per forecast day. The initial error between the model and the observation is $0.66^{\circ} \mathrm{C}$, which is in line with earlier verification work on this model. The temperature variation from month to month is quite large, as can be seen from the in situ measurements (Figure 4).

The R-Q-Q plot (Figure 5) shows how most of the forecasts produce quantile distributions somewhat Sshaped and at an angle to the horizontal. The S-shape indicates that the distribution of the forecast values is not as wide as that of the observations, that is, the minimum and maximum temperatures are not well produced by the model. This is in good agreement with the rank histogram, which also suggests the same conclusion. From the R-Q-Q plot, one can also see that the curves have a positive slope, which implies that the climatological variance is larger within the ensemble than within the observations. The summers 2008 and 2009 are marked with different colours: the years are not alike.

\section{Case study: upwelling on the west coast of Finland from 1 August to 5 August 2008}

We studied more closely the system's ability to forecast an upwelling event that took place on the Finnish coast of the Bothnian Bay from 1 August to 5 August 2008 (Figure 6). This event extended over a $200 \mathrm{~km}$ stretch of the Finnish coast, and lasted for five days. In the first forecast, starting on 17 July, $16 \%$ of the ensemble members predicted upwelling (Figures 7 and 8, upper panel), while in the second forecast, starting on 24 July, already $20 \%$ of the ensemble members predicted upwelling (Figures 7 and 8 , middle panel). In the third forecast, starting $31 \mathrm{July}$, all the ensemble members predicted cooling, and $82 \%$ predicted upwelling on 2 August (Figures 7 and 8, lower panel). It can be seen that the distribution of the temperature rate of change is clearly skewed towards negative values, indicating cooling in all the forecasts. This becomes more pronounced as the event gets closer.

\section{Discussion}

Several upwelling events along the coast of the Gulf of Bothnia during the years 2008 and 2009 were studied using the ensemble prediction system. Verified upwelling events were only detected in 2008. The reproduction of 


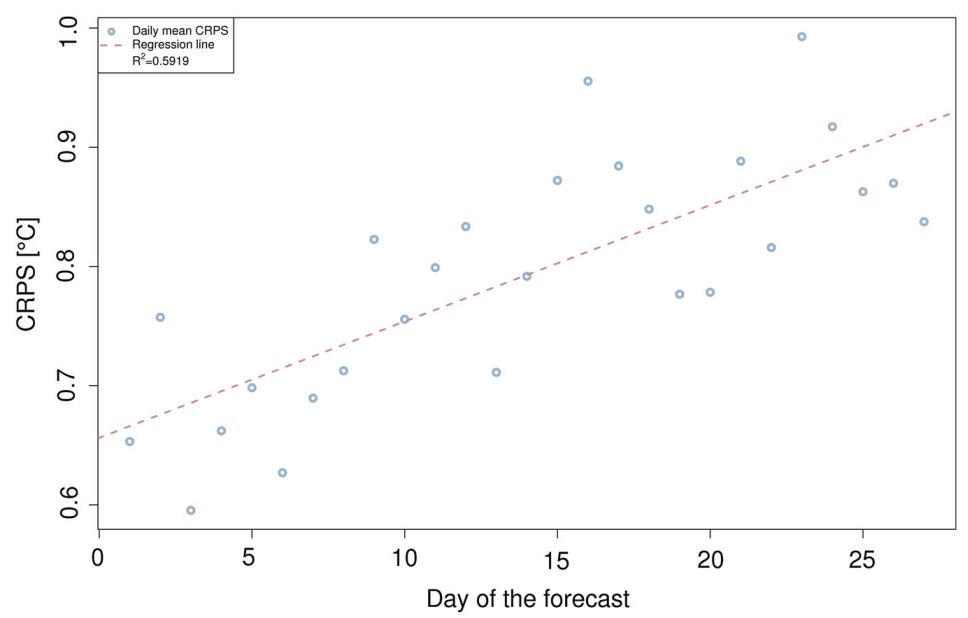

Figure 3. Mean daily CRPS.

Note: The equation for the regression line is $y=0.00976 x+0.65623 . R^{2}=0.5919$.

the upwelling cases was analysed and the confidence in forecasts in monthly scale was evaluated.

Atmospheric conditions strongly affect the phenomenon, and just a small displacement or change in the strength of the wind pattern can make the difference between an upwelling event happening or not. This is why ensemble prediction is suitable for predicting upwelling - and, moreover, for quantifying its likelihood - since this method produces its forecast from slightly perturbed atmospheric input fields. In the end, upwelling is dependent on wind speed, direction and duration, and the stratification of the water column.

\section{Upwelling forecasts}

Upwelling events are triggered by atmospheric phenomena, for example, a low pressure system. It is difficult to predict the timing and location of these systems precisely. Nevertheless, these upwelling events can be seen in different forecasts in slightly different places or at slightly different times, even though their original trigger is in fact the same phenomenon. In the sea, changes are slower, and the inertia of the fluid is greater than in the atmosphere. It is therefore possible to see traces of weather phenomena in the sea after they are no longer

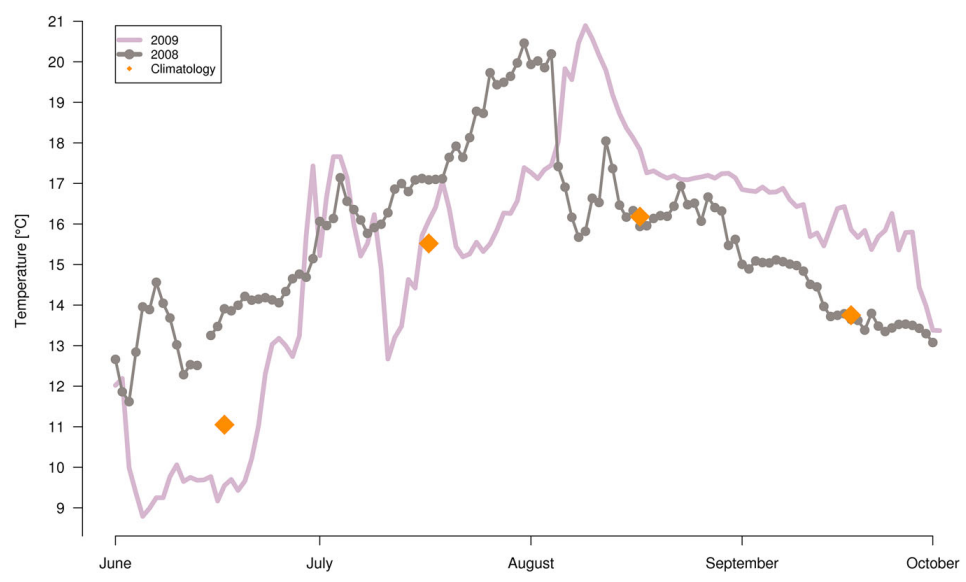

Figure 4. Temperature observations from the Northern Baltic buoy (cf. Figure 1), and climatology. Note: Climatology is from the OCEANSITES project and the national programmes that contribute it. 


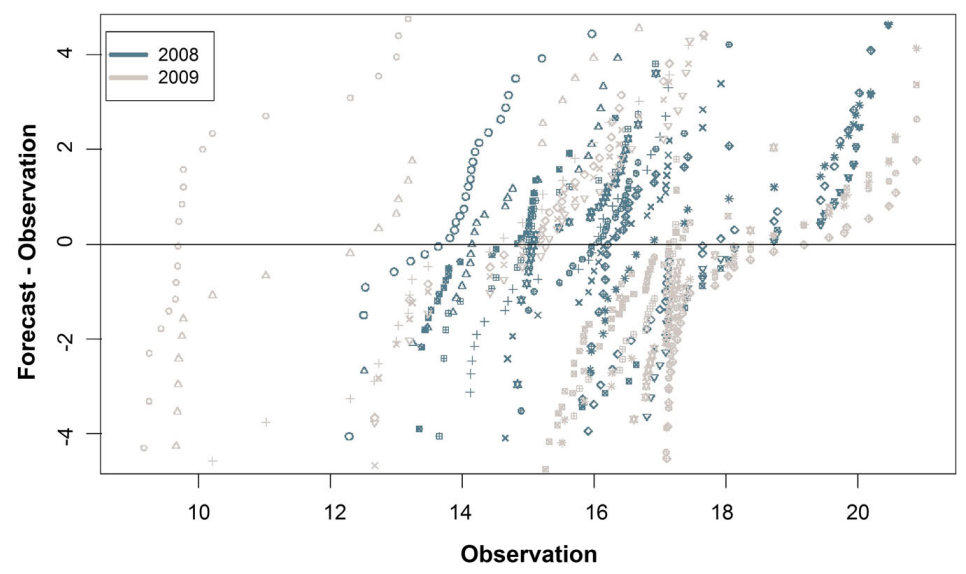

Figure 5. Residual quantile-quantile plots for monthly ensemble forecasts for the summers 2008 and 2009.

Note: The values on both axes are degrees in Celsius.

visible in the atmosphere. In upwelling cases, the location plays an important role. Small changes in the wind pattern have a stronger effect on smaller coastal areas than they do on larger coastal areas.

The threshold limit for upwelling was set to be $1^{\circ} \mathrm{C} /$ day. On one hand, it is unlikely that such a change in temperature would be produced by other phenomena, for example, cold air advection, especially during summer. On the other hand, this limit is still low enough that important events are not missed. In the early summer the ensemble forecast distribution tend to have the greatest number of positive members as the water temperature is rising. In the late summer, the situation is the opposite, when the water is cooling.
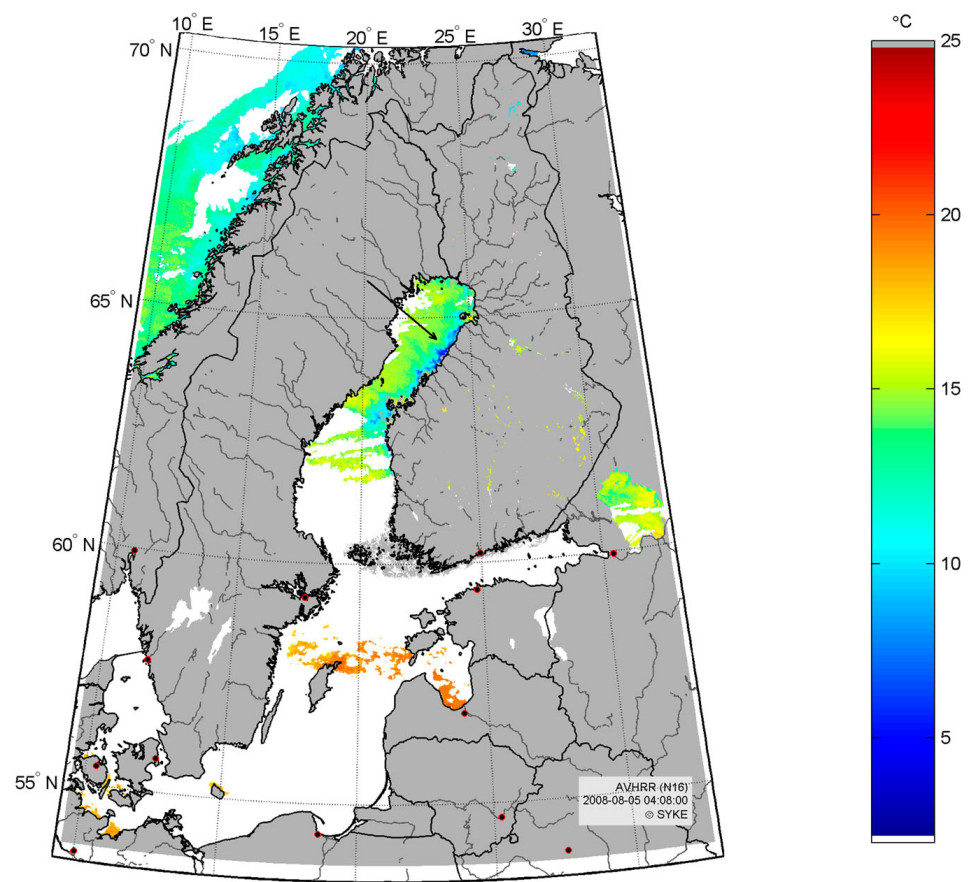

Figure 6. Satellite image of sea surface temperature for 5 August 2008. Source: SYKE (2016). Accessed 17 November 2016. Note: The area of interest is indicated by an arrow. 


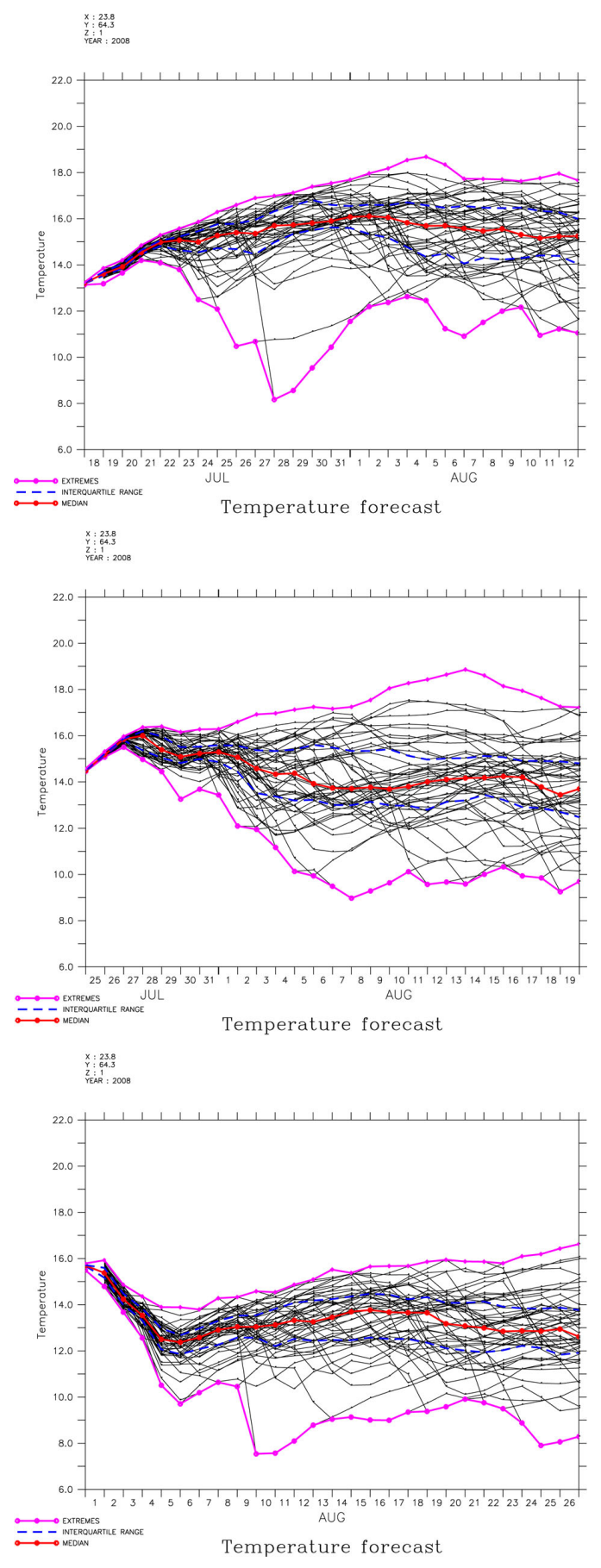

Figure 7. Three sequential monthly ensemble SST forecast plumes for the west coast of Finland (Figure 4). Note: Upwelling was detected 1 August lasting until 5 August.
Forecasts in the study were illustrated with two types of graph: the traditional ensemble plume - which shows the development of the temperature in 50 different, physically realistic scenarios - and the violin plot. These forecasts show the daily change in the temperature; in this study, over a period of 27 days. This is useful when there is a need to estimate the rate of change of SST, for example, during upwelling events when the cooling is relatively fast.

Since upwelling as a mesoscale phenomenon is scaled by the Rossby radius, the grid size should also be of that order or even finer (Lehmann \& Myrberg 2008). In this study, the model grid size was $6 \mathrm{NM}$ (around $11.1 \mathrm{~km}$ ), which is close to the reported upper limit of the baroclinic Rossby radius in the Baltic Proper (Alenius et al. 2003). There is very limited data available on the Rossby radius in the Gulf of Bothnia, but it is generally expected to be of the same order as that of the Baltic Proper.

\section{The performance of the forecasting system}

The verification of the system showed that the forecasts and observations differ somewhat. The three methods used in this study showed similar results.

Rank histograms are a widely used method for the evaluation of meteorological ensemble forecasts. They are well suited for meteorological applications because the availability of observations is relatively good for them. As Hamill (2001) points out, rank histograms do not give meaningful results unless computed on a fairly large sample. Part of the overestimates and underestimates in the rank histogram (Figure 2) might be due to the unperturbed initial conditions of the ocean state and on boundaries, which cause the first day of the forecast to be (in most cases) different from observation. The perturbance of the other variables and boundary conditions should be done so that physical realism is preserved.

The rank histogram showed that the dispersion is too small, which is along the lines of the R-Q-Q plot. Also the systematic error can be seen in the CRPS score as well as in the R-Q-Q plot. In general, it is possible to see the growth rate of the error during the monthly forecast from the CRPS.

Although a detailed analysis of the physical reasons behind this kind of forecast behaviour needs more study, some preliminary reasons for the nonconformities are presented here. One reason behind the lack of dispersion in the model could be the fairly coarse resolution and too large vertical mixing in the model. 


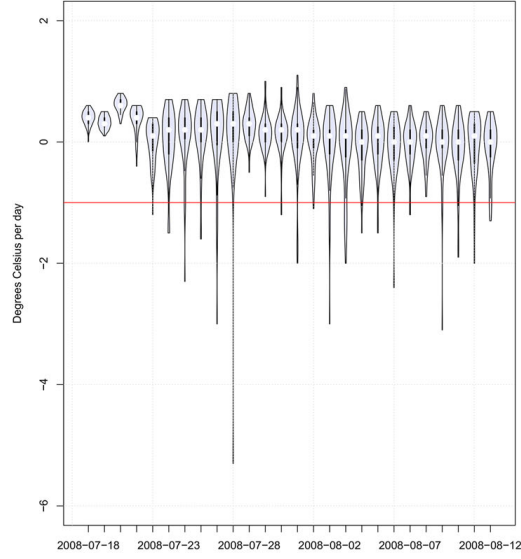

Date

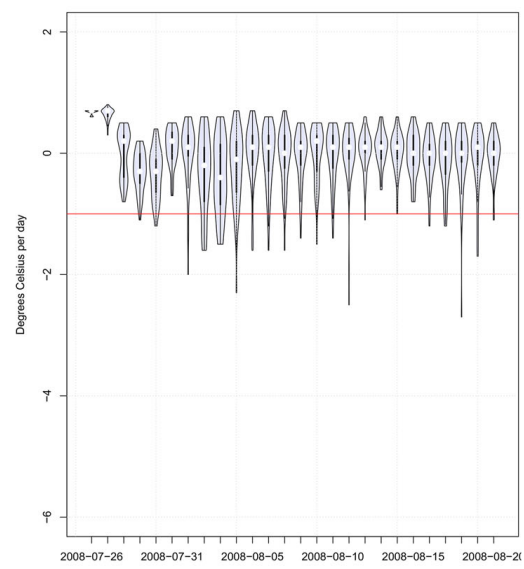

Date

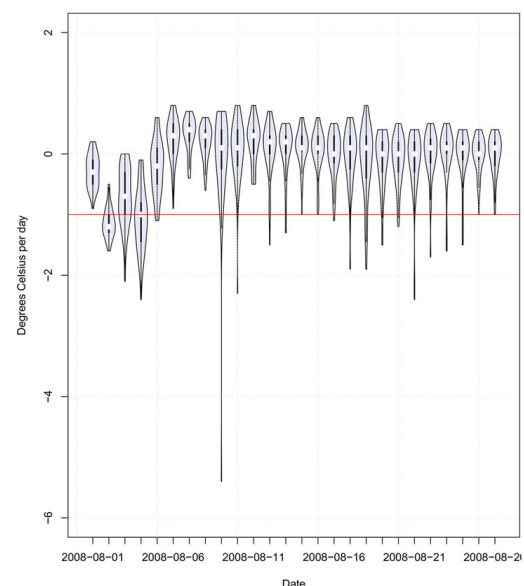

Figure 8. Three sequential violin plots of temperature rate of change for the west coast of Finland (Figure 6).

Notes: Upwelling was detected 1 August, and it lasted until 5 August. The defined limit for upwelling, $1^{\circ} \mathrm{C} /$ day, is marked on the plot by a red line.
The highest temperatures tend to occur on warm days, when the wind is relatively calm. In this situation, a shallow surface layer might warm up a great deal more than the whole mixed layer, thus forming a so-called sub-thermocline near the surface. When the surface layer of a numerical model is used for comparison with the observations, it might be that the observation reflects the temperature of the shallow surface layer at one location, while the modelled temperature reflects the mean temperature of the deeper mixed layer over a larger area, resulting in a relatively large temperature difference.

It is not clear why the coldest temperatures are not well produced in the forecast. This again might be related to an excess of vertical mixing in the model, resulting in too deep a mixed layer with a weaker temperature gradient in the thermocline. In this case, the enhanced mixing would result in higher temperatures than the observations show. The known warm bias also explains part of the model's inability to produce the coldest temperatures.

The performance of the forecast is different in different geographical locations (Marzban et al. 2011). Thus, more observations from different places are needed in order to gain a more comprehensive view of the forecast behaviour.

\section{Conclusions}

Ensemble forecasting on monthly time-scale appears to be a promising tool in operational oceanography. However, the challenges of this approach are somewhat different when applied to oceanography than in some of the more established applications, such as weather forecasting. For example, compared to the atmosphere the characteristics of sea water are different, and the availability of observations is much more sparse. Furthermore, the Baltic Sea has its own particular characteristics, adding to the list of things to take into consideration.

As mentioned in previous sections, sea water has a high density and heat capacity compared with the atmosphere. This means that the scale of phenomena, both spatial and temporal, is different from that of the atmosphere. While this might mean longer predictability for some phenomena, caution is in order and each phenomenon should be considered separately. The start of an upwelling event, for example, might be as difficult to predict as any atmospheric phenomenon. But at the same time, upwelling events, once initiated, can outlast the triggering wind event. It might therefore be plausible to conjecture that the duration of this phenomenon could 
be more easily predicted than its start. But this needs further research.

There has been very little research into how oceanic ensemble forecasting differs from other applications. As the Baltic Sea is semi-enclosed, quite small and has a complex coastline, phenomenon such as upwelling is quite common and important. This highlights the need for a sufficiently high resolution in modelling, and improving this aspect is important once more computational capacity makes this practical. As for now, too many aspects of ensemble forecasts are limited by computer capacity.

In spite of these difficulties, the ensemble approach has clear advantages for oceanic applications, even when forecasting relatively poorly known and difficultto-capture phenomena such as upwelling. In this study, it is shown that on the time range of less than a week, the forecast accuracy is excellent, and even on time ranges from a week to two weeks, forecasts show adequate accuracy. Methods used in other applications were applied here and developed further to suit oceanic uses.

\section{Acknowledgements}

The authors want to thank the organisers and participants of the 4th International Verification Methods Workshop for ideas on ensemble forecasting, and Dr Tapani Stipa, Mr Aleksi Nummelin, Prof. Jari Haapala and Dr Laura Tuomi for their insightful comments. The satellite SST data is available under Creative Commons By 4.0 International license and is processed by Finnish Environment Institute.

\section{Disclosure statement}

No potential conflict of interest was reported by the authors.

\section{Funding}

Development of the FMI ensemble forecasting system has been partly financed by European Union Commission 6th framework project ECOOP European COastal-shelf sea OPerational Observing and forecasting system [contract number 036355] and the Copernicus MyOcean project.

\section{ORCID}

Petra Roiha (D) http://orcid.org/0000-0001-9585-206X Antti Westerlund (iD) http://orcid.org/0000-0003-2006-3079

\section{References}

Alenius P, Nekrasov A, Myrberg K. 2003. Variability of the baroclinic Rossby radius in the Gulf of Finland. Cont Shelf Res. 23:563-573.
Alfieri L, Salamon P, Pappenberger F, Wetterhall F, Thielen J. 2012. Operational early warning systems for water-related hazards in Europe. Environ Sci Policy. 21:35-49.

Anderson JL. 1996. A method for producing and evaluating probabilistic forecasts from ensemble model integrations. J Clim. 9:1518-1530.

Bauer P, Thorpe A, Brunet G. 2015. The quiet revolution of numerical weather prediction. Nature. 525:47-55.

Brankovic C, Palmer T. 1997. Atmospheric seasonal predictability and estimates of ensemble size. Mon Wea Rev. 125:859-874.

BSHC. 2013. Baltic Sea Bathymetry Database version 0.9.3. [Internet]. [cited 2015 Jan 21]. Available from: http://data. bshc.pro/

Buizza R. 1997. Potential forecast skill of ensemble prediction and spread and skill distributions of the ECMWF Ensemble Prediction System. Mon Wea Rev. 125:99-119.

Casati B, Wilson L, Stephenson D, Nurmi P, Ghelli A, Pocernich M, Damrath U, Ebert E, Brown B, Mason S. 2008. Forecast verification: current status and future directions. Meteorol Appl. 15:3-18.

Ebert EE. 2001. Ability of a poor man's ensemble to predict the probability and distribution of precipitation. Mon Wea Rev. 129:2461-2480.

Golbeck I, Li X, Janssen F, Brüning T, Nielsen J, Huess V, Söderkvist J, Büchmann B, Siiriä S-M, Vähä-Piikkiö O, et al. 2015. Uncertainty estimation for operational ocean forecast products - a multi-model ensemble for the North Sea and the Baltic Sea. Ocean Dyn. 65:1603-1631.

Haapala J. 1994. Upwelling and its influence on nutrient concentration in the coastal area of the Hanko Peninsula, entrance of the Gulf of Finland. Estuar Coast Shelf Sci. 38:507-521.

Håkansson B, Alenius P, Brydsten I. 1996. Physical environment in the Gulf of Bothnia. Ambio Special Report 15.

Hamill TM. 2001. Interpretation of rank histograms for verifying ensemble forecasts. Mon Wea Rev. 129:550-560.

Hersbach H. 2000. Decomposition of the continuous ranked probability score for ensemble prediction systems. Wea Forecast. 15:559-570.

Hintze J, Nelson R. 1998. Violin plots: a box plot-density trace synergism. Am Stat. 52:181-184.

Jolliffe I, Stephenson D, editors. 2003. Forecast verification - a practitioner's guide in atmospheric science. Chichester: John Wiley.

Kiiltomäki A. 2008. Development of the Baltic Sea indicator report by Algaline measurements and BalEco model results [M. Phil. thesis]. Helsinki: University of Helsinki.

Krauss W, Brügge B. 1991. Wind-produced water exchange between the deep basins of the Baltic Sea. J Phys Oceanogr. 21:373-384.

Lehmann A, Myrberg K. 2008. Upwelling in the Baltic Sea - a review. J Mar Syst. 74:S3-S12.

Lehmann A, Myrberg K, Höflich K. 2012. A statistical approach to coastal upwelling in the Baltic Sea based on the analysis of satellite data for 1990-2009. Oceanologia. 54:369-393.

Leppäranta M, Myrberg K. 2009. Physical oceanography of the Baltic Sea. 1st ed. Chichester: Praxis.

Lermusiaux P. 2006. Uncertainty estimation and prediction for interdisciplinary ocean dynamics. J Comput Phys. 217:176-199. 
Leutbecher M, Palmer TN. 2008. Ensemble forecasting. J Comput Phys. 227:3515-3539.

Löffler A, Schneider B, Perttilä M, Rehder G. 2012. Air-sea $\mathrm{CO}_{2}$ exchange in the Gulf of Bothnia, Baltic Sea. Cont Shelf Res. 37:46-56.

Marshall J, Adcroft A, Hill C, Perelman L, Heisey C. 1997. A finite-volume, incompressible Navier Stokes model for studies of the ocean on parallel computers. J Geophys Res Oceans. 102:5753-5766.

Marshall J, Hill C, Perelman L, Adcroft A. 1997. Hydrostatic, quasi-hydrostatic, and non-hydrostatic ocean modeling. J Geophys Res Oceans. 102:5733-5752.

Marzban C, Wang R, Kong F, Leyton S. 2011. On the effect of correlations on rank histograms: reliability of temperature and wind speed forecasts from finescale ensemble reforecasts. Mon Weather Rev. 139:295-310.

Meier HEM, Andersson HC, Eilola K, Gustafsson BG, Kuznetsov I, Müller-Karulis B, Neumann T, Savchuk OP. 2011. Hypoxia in future climates: a model ensemble study for the Baltic Sea. Geophys Res Lett. 38. doi:10.1029/ 2011GL049929

Molteni F, Buizza R, Palmer T, Petroliagis T. 1996. The ECMWF ensemble prediction system: methodology and validation. Q J R Meteorol Soc. 122:73-119.

Mylne KR, Evans RE, Clark RT. 2002. Multi-model multianalysis ensembles in quasi-operational medium-range forecasting. Q J R Meteorol Soc. 128:361-384.
Myrberg K, Andrejev O. 2003. Main upwelling regions in the Baltic Sea - a statistical analysis based on three-dimensional modelling. Boreal Environ Res. 8:97-112.

Palmer TN, Molteni F, Mureau R, Buizza R, Chapelet P, Tribbia J. 1993. Ensemble prediction. In: Proceedings of the Validation of Models over Europe (Vol. 1); Shinfield Park, Reading, United Kingdom, ECMWF; p. 21-66.

Richardson DS. 2000. Skill and relative economic value of the ECMWF ensemble prediction system. QJR Meteorol Soc. 126:649-667.

Roiha P, Westerlund A, Nummelin A, Stipa T. 2010. Ensemble forecasting of harmful algal blooms in the Baltic Sea. J Mar Syst. 83:210-220.

Seifert T, Kayser B. 1995. A high resolution spherical grid topography of the Baltic Sea. Meereswissenschaftliche Berichte. 9:72-88.

SYKE. 2016. Remote sensing products, Sea Surface Temperature. [Internet]. [cited 2016 Nov 17]. Available from: www.syke.fi/earthobservation

Tracton MS, Kalnay E. 1993. Ensemble forecasting at NMC: operational implementation. Wea Forecast. 8:379-398.

Vahtera E, Laanemets J, Pavelson J, Huttunen M, Kononen K. 2005. Effect of upwelling on the pelagic environment and bloom-forming cyanobacteria in the western Gulf of Finland, Baltic Sea. J Mar Syst. 58:67-82.

Wilks DS. 2011. Statistical methods in the atmospheric sciences. Amsterdam: Elsevier. 



\section{Publication V}

Petra Roiha, Antti Westerlund, Aleksi Nummelin and Tapani Stipa. Ensemble forecasting of harmful algal blooms in the Baltic Sea. Journal of Marine Systems, 83, 3, 210-220, 112010. 



\title{
Ensemble forecasting of harmful algal blooms in the Baltic Sea
}

\author{
Petra Roiha*, Antti Westerlund, Aleksi Nummelin, Tapani Stipa \\ Finnish Meteorological Institute, Erik Palménin aukio 1, P.O.Box 503, FI-00101 Helsinki, Finland
}

\section{A R T I C L E I N F O}

\section{Article history:}

Received 1 October 2009

Received in revised form 12 February 2010

Accepted 16 February 2010

Available online 4 March 2010

\section{Keywords:}

Prediction

Algal blooms

Ensemble forecasting

Baltic Sea

$\left(8.7^{\circ}\right.$ E $\left.53.85^{\circ} \mathrm{N}\right)$

$\left(30.3^{\circ} \mathrm{E} 65.85^{\circ} \mathrm{N}\right)$

\begin{abstract}
A B S T R A C T
Operational marine environmental modelling has been considered notoriously difficult; consequently there are very few operational models of the marine environment. Operational modelling of harmful algal blooms (HABs) requires the modelling of individual species and is therefore harder still. The separation of algal species in models requires detailed knowledge of their behaviour (survival strategy through the life cycle), and physiological ecology.

We present quantitative results of an ensemble approach to HAB forecasting in the Baltic, and discuss the applicability of the forecasting method to bioheochemical modelling. Ensembles were produced by running a biogeochemical model several times and forcing it on every run with different set of seasonal weather parameters from European Centre for Medium-Range Weather Forecasts' (ECMWF) mathematically perturbed ensemble prediction forecasts. The ensembles were then analyzed by statistical methods and the median, quartiles, minimum and maximum values were calculated for estimating the probable amounts of algae. To evaluate the forecast method final results were compared against available and valid in-situ HAB data in a case study. It turns out that quantitative $\mathrm{HAB}$ forecasts are possible. Further verification will require expanded observational networks.
\end{abstract}

(c) 2010 Elsevier B.V. All rights reserved.

\section{Introduction}

Modelling of non-linear variables always includes uncertainties from different sources. The initial conditions might be inaccurate, the model input has errors and the modelling of ocean conditions is not exact because of truncation errors and inaccuracies in the modelling of subscale phenomena (Leutbecher and Palmer, 2008). Therefore the solution deteriorates in time.

The deterioration of model forecasts with time is a well-known issue in weather forecasting, where the reliable forecast range is about a week. In oceans the predictability of some phenomena is typically longer. For example, the internal weather of the sea, the oceanic mesoscale, includes mainly phenomena which are occurring in temporal scales from days to months and spatial scales from kilometres to hundreds of kilometres (Lermusiaux, 2006). However, ocean predictability is rarely exploited to its useful limits. Most operational ocean forecasting is limited to ten day forecasts in the maximum, or to coupled atmosphere-ocean seasonal forecasts where the focus is nevertheless on the atmospheric forecast.

Physical ocean models are principally built on the same wellknown and relied upon equations as atmospheric models, and have similar inherent limitations to their predictive skills. Biogeochemical models, on the other hand do not enjoy a firm basis provided by e.g.

\footnotetext{
* Corresponding author.

E-mail address: petra.roiha@fmi.fi (P. Roiha).
}

the primitive equations of ocean motions. Furthermore, the initial condition for a biogeochemical forecast is often not well observed, and the uncertainties are large. While there are significant constraints to how biogeochemical models are to be constructed (Redfield, 1958), the uncertainties involved in using biogeochemical models for forecasting appear to deserve an explicit treatment. This is particularly true with models intended to predict not only the overall biogeochemical processes, but also the behaviour of individual species.

In harmful algal bloom (HAB) forecasts a relationship between phosphorus concentration and cyanobacterial blooms has been recognized for decades (Niemi, 1979; Niemistö et al., 1989; Kahru et al., 2000). This relationship has been utilized for practical and even operational purposes. These operational estimates of cyanobacterial bloom probability and severeness have, however, been based mostly on the wintertime (January-February) nutrient concentration fields and best and worst case scenarios for summer weather conditions, without accounting for the actual weather development and forecasts.

Janssen et al. (2004) demonstrated with model experiments that a relationship between winter nutrients and summer cyanobacterial blooms, in agreement with the inferences of Kahru et al. $(2000,2007)$, is replicated with biogeochemical 3-dimensional numerical model.

Biogeochemical ensemble forecastss offer a quantitative tool for the assessment of $\mathrm{HAB}$ related environmental risks for a wide range of applications. Ensembles have been an essential tool in meteorology for many years. In comparison with a single deterministic forecast, ensembles offer the benefit of estimates of bias, deviation and range of the modelled variables from real life situation. It is also possible to 
analyze the ensembles and recognize forecasts with low skill (Buizza, 1997).

There are several ways to dissect the ensemble. Variables can be studied by e.g. calculating the ensemble mean, which provides an estimate of the probabilistic expectation forecast. The ensemble can also be divided into smaller sub-ensembles to make alternative forecasts (Brankovic and Palmer, 1997) and even individual members can be used for prediction purposes. Ensembles can be used as a quantitative tool for risk assessment. The potential economic value can be much higher in many applications than the value of deterministic forecast (Richardson, 2000).

In this work we explore the predictability of ensemble HAB modelling and demonstrate the usefulness of such forecasts in environmental policymaking and risk assessment. The operational ocean model used in this study has been examined closely by Kiiltomäki (2008) and accuracy of the deterministic model has been evaluated against observations. Previously it has been used for bloom forecasting as a part of ad hoc ensembles with the help of expert insight, cf. FIMR and SYKE (2006). Our system widens this approach by formalizing the forecasting process in a computationally sound manner. Our approach brings greater consistency of the forecasting process with actual weather forecasts. Causes for the phenomena seen in the results can be traced more easily, giving more information for forming the final forecast.

\section{Materials and methods}

\subsection{Model configuration}

For forecasting we used FMI (Finnish Meteorological Institute) operational 3-dimensional biogeochemical model, Baleco. The model consists of a general circulation model (Marshall et al., 1997a,b) and an ecological module. The model is discretized on a spherical polar grid. The grid size is $0.1^{\circ}$ in longitudinal and $0.2^{\circ}$ in latitudinal direction (around $11.1 \mathrm{~km}$, or 6 nautical miles) and the model domain reaches 120 grid cells in latitudinal, 108 grid cells in longitudinal and 21 grid cells in vertical direction. The model domain's most south-western corner is located at $\left(53.85^{\circ} \mathrm{N}, 8.7^{\circ} \mathrm{E}\right)$. The vertical resolution of the model is concentrated to the euphotic zone so that the top most layer is $3 \mathrm{~m}$, reduced to $2 \mathrm{~m}$ in the cells hugging the coast (Kiiltomäki, 2008). The bottom topography (Fig. 1) is from Seifert and Kayser (1995). The spatial discretization is made with minimum filter at $6 \mathrm{~nm}$ intervals.

The ecological model is based on ecosystem dynamics formalized by Aksnes et al. (1995) and Tyrrell (1999). The model consists of three phytoplankton groups: diatoms, flagellates and cyanobacteria. These groups have constant mortality rates and they use phosphate, silicate and dissolved inorganic nitrogen. Diatoms are potentially limited by availability of silicate. Cyanobacteria can fix molecular nitrogen and therefore they are not limited by availability on DIN. The flagellates group represents autotrophic flagellates. Altogether the ecosystem model describes the essence of new production in the presence of three functional groups. The growth rates depend on nutrient concentrations, irradiation and temperature (Stipa et al., 2003). For model equations see Appendix A.

Model runs obtained their initial state from FMI's deterministic Baltic Sea forecast for the start date of the run. The deterministic forecast's initial conditions, both physical and chemical, were obtained from winter monitoring data of the HELCOM COMBINE program for the winter 2007-2008. The observations were interpolated in three dimensions with a robust nearest neighbour interpolation and then supplemented by climatological values for the North Sea from the World Ocean Atlas (Boyer et al., 2006).

\subsection{Ensemble forecasts}

The ensemble prediction system (EPS) is a technique to predict the probability distribution of forecast states, given a probability dis- tribution of random error in inputs and model error. Ensemble forecasts are formed by several slightly perturbed ensemble members.

Ensemble forecasts include more information than a single deterministic forecast and therefore the analysis can give us a deeper insight to many phenomena. Every ensemble member represents one possible evolution of the system state in time and space. Therefore the variety of applicable analysis approaches is very wide, when compared to deterministic forecasts.

One of the oldest and simplest analysis methods is to calculate ensemble mean to define the mean trajectory. It is also possible to calculate some statistical values for analysis. These values can be, for example, minimum and maximum values, which indicate the extreme values, and $25 \%$ and $75 \%$ quartiles of the ensemble spread. Another useful approach is to compute the percentage of ensemble members for which a given variable exceeds some limiting value, which can then be interpreted as a probability of the event.

Ensembles in our study were created from an unperturbed initial condition by running the model several times with different sets of weather boundary conditions. The weather ensembles were made by ECMWF using singular vector method (Molteni et al., 1996). Weather parameters used as external forcing for ocean model were 6 hourly $10 \mathrm{~m}$ winds and $2 \mathrm{~m}$ dew point temperature and $2 \mathrm{~m}$ temperature, 12 hourly surface solar radiation and surface thermal radiation. These weather ensembles include 50 perturbed ensemble members and an additional deterministic unperturbed control run. These were used to generate a 28-day ensemble runs for the Baltic Sea for June, July and August of 2008. ECMWF makes new monthly forecasts available once a week, so for this three month period this meant altogether 13 ensemble runs, of which some were chosen for further analysis.

The ensemble forecast produced in this work gives the probability of cyanobacteria concentrations. The forecast shows where the harmful algal concentrations are high and thus the appearance of blooms is more likely.

\subsection{Chlorophyll-a conversion}

As the model gives the amount of cyanobacteria in molar amount of nitrogen $(\mathrm{N})$ we have used a special $C: N$ ratio, the molar mass number of carbon (12.01) and C:Chla ratio to calculate the chlorophyll-a concentrations in $\mathrm{mg} \mathrm{m}^{-3}$. Since this work concentrates on the Baltic Sea, we have used $C: N=6.3$, which is based on studies made in the area: Walve and Larsson (2007) found out that $C: N$ ratio in the cyanobacteria in Western Gotland basin was 6.2-6.4 \pm 0.3 , the highest ratio being 7.3. Another study made by Nausch et al. (2009) supports these values as they found that the mean $C: N$ ratio was 6.2 in the Eastern Gotland basin.

The Carbon:Chlorophyll-a ratio $\eta$ is also variable, and depends on properties of the study area, the state of the bloom and most of all on the algal species studied, e.g. it is known that C:Chla ratio is usually larger in cyanobacteria than in other algae as they have also other pigments that can be used in light harvesting (Geider et al., 1997). Geider et al. found the minimum C:Chla to be approximately 38-67 for different kinds of cyanobacteria, although the study was not done in the Baltic Sea. Eker-Develi et al. (2008) found the mean C:Chla ratio for cyanobacteria to be 33 in Southern Baltic Sea, although there was significant variability, standard deviation being 35 . In addition to these findings Engström-Öst et al. (2002) reported a high POC:Chla $(<10 \mu \mathrm{m})$ ratio, $427 \pm 185$, during cyanobacterial bloom decay, although POC does not equal C exactly. Based on these results the C:Chla ratio is a significant source of uncertainty. This is further discussed in Section 4.3.

With these configurations the chlorophyll-a (Chla) concentration in $\mathrm{mg} \mathrm{m}^{-3}$ was calculated from the model results with the formula

Chla $=\frac{N_{c} \cdot 6.3 \cdot 12.01}{\eta} \approx \frac{N_{c}}{\eta} \cdot 76$, 


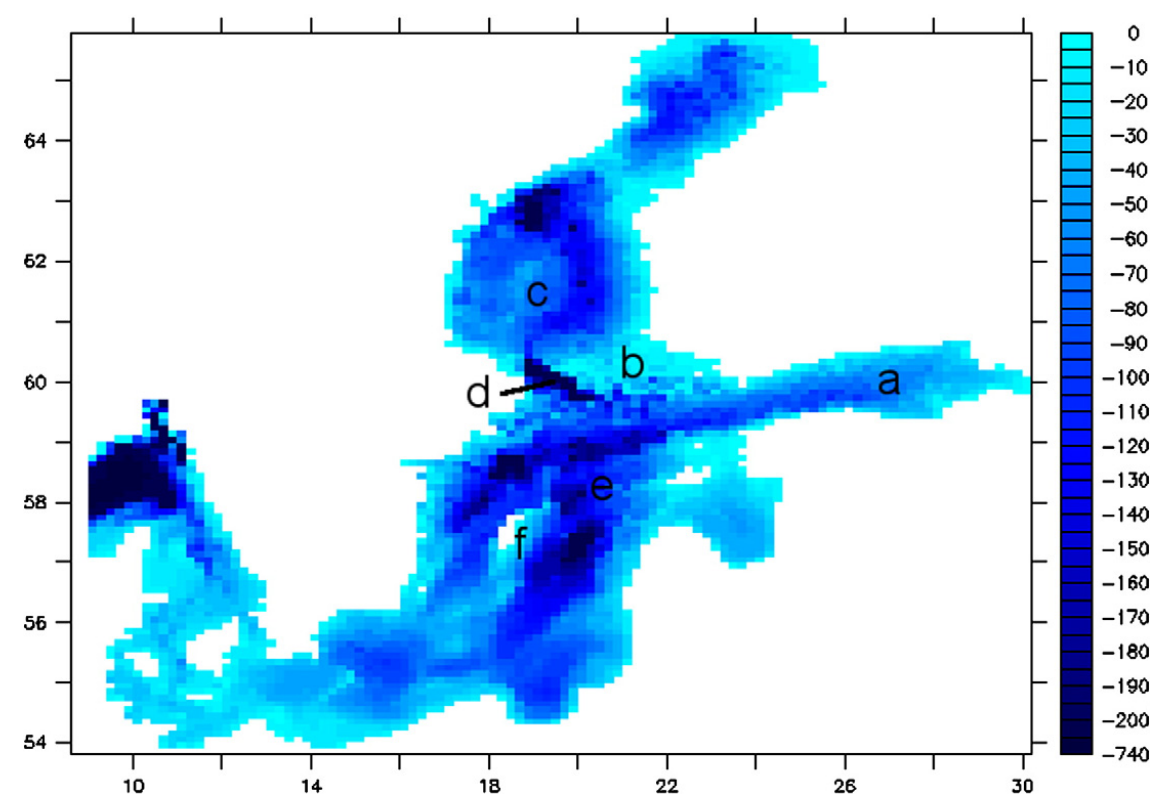

Fig. 1. Bottom topography ( $\mathrm{m}$ ) of the Baleco model. Also indicated on the map are the following geographic references used in the article: a) Gulf of Finland, b) Sea of Archipelago, c) Bothnian Sea, d) Sea of Åland, e) Baltic Proper and f) Gotland.

where $N_{c}$ is the molar mass of cyanobacteria produced by the model. The $C$ :Chla ratio, $\eta$, is given for specific events separately. As a limit for the cyanobacterial occurrence we used chlorophyll-a concentration of $2.0 \mathrm{mg} \mathrm{m}^{-3}$ which is based on studies by Seppälä and Balode (1999), Nausch et al. (2004) and Kutser et al. (2006).

\section{Results}

3.1. Case study: harmful algal blooms and upwelling in the Baltic Sea, June 2008

The summer weather of 2008 was cool and windy and thus large scale HABs were absent. The overall algal bloom situation can be seen in Fig. 2. In June and August blooms were milder than usual, in July the situation was average (HELCOM, 2009). In the beginning of July the sea water temperature increased a few degrees and the concentration of cyanobacteria increased in the Gulf of Finland. Cyanobacteria were mainly mixed in the water column. The Sea of Åland had some blooms. From the middle July to end of July the algal blooms increased first in southern Sea of Archipelago, Sea of Åland, eastern Gulf of Finland and southern Bothnian Sea. In the end of July the blooms were more frequent and small blooms were present all along of the Gulf of Finland. The summer bloom culminated in the end of July, when the maximum extent (approximately $180,000 \mathrm{~km}^{2}$ ) of algae blooms was observed. However the normalized bloom indices for bloom extent $\left(6575 \mathrm{~km}^{2}\right)$, duration (4.9 days) and intensity (32,651 $\mathrm{km}^{2}$ days) were lower than the mean for the period 1997-2007.

In our case study we saw an upwelling on the east coast of Gotland on the 24th of June. We show here how different weather scenarios affect ocean conditions and how ensemble forecasts see different biogeochemical phenomena.

Upwelling is very often strong enough for the sea-surface temperature to be affected, and thus low temperatures in a thin strip near the coasts are a signature of upwelling. Upwelling can also be seen in the colour of the water and in the abundance of sea life (Gill, 1982).
Temperature and nutrient ensembles (Fig. 3a, c and d) and cyanobacterial concentrations (Fig. 4) show an upwelling event in the area. It can be seen that some weather scenarios cause upwelling while other possible scenarios do not. The cyanobacteria ensemble (Fig. 3b) and biomass observations (Fig. 5) from Algaline's automated ferrybox sampling (Ruokanen et al., 2003) show evidence of upwelling. The lower cyanobacteria biomass concentrations observed near the coast are captured by a large number of ensemble forecast members.

\subsection{Comparison between observations and forecast}

It is desirable to evaluate the quality of a probabilistic prediction system not only in terms of the intrinsic quality of the results it produces but also in terms of cost efficiency (Talagrand et al., 1999). In $\mathrm{HAB}$ validation the available observational data is very sparse and often qualitative in nature. Therefore the validation is especially challenging.

Fig. 6 shows the observed situation in the end of July 2008, when the HAB was at its peak. The observations are done by volunteers, environmental authorities and Finnish border guards. Several kinds of observations are combined in this figure. Observations are mainly visual especially near the Finnish coast and there is no data about biogeochemical variables during the phenomenon.

Contrast this with Fig. 7, showing HAB probability maps produced from an ensemble forecast for the same time. Unlike the observations, these maps are based on probabilities of quantitative values of cyanobacteria chlorophyll-a as predicted by the model. Therefore, it is not predicting directly the concentration of chlorophyll-a but rather the possibility of the blooms. This is further illustrated in Fig. 8 showing single members of the ensemble.

From Figs. 6 and 7 it can be seen that in the Gulf of Finland there are several observations of HABs in the areas where they were predicted. We can also see that in the Northern Baltic Proper the predicted bloom area is considerably to the East of the observed blooms, although with lower values of $\eta$ the edge does move westward. Furthermore, there 


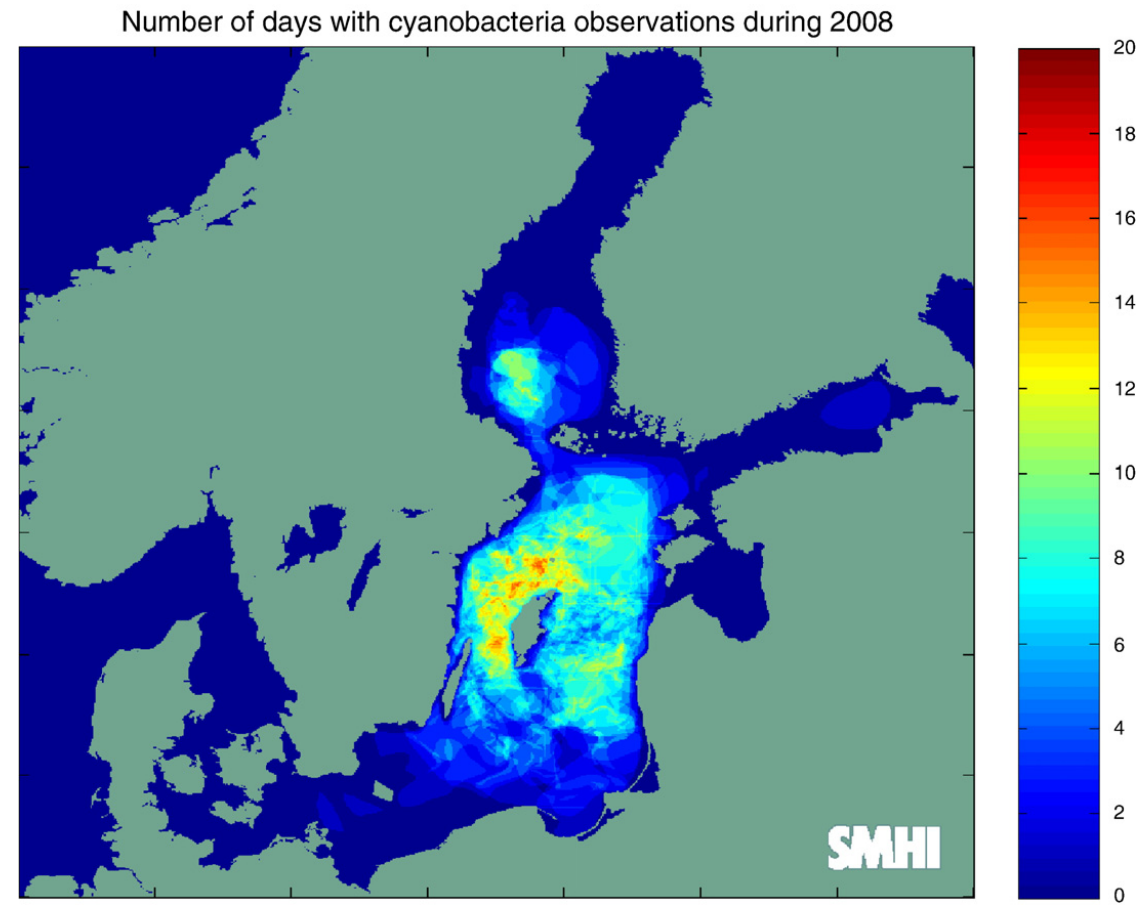

Fig. 2. Number of days with cyanobacteria observations by NOAA-AVHRR satellite imagery during 2008 (HELCOM, 2009). Courtesy: SMHI.

are no blooms forecasted for the Sea of Archipelago, yet there are several observations of blooms.

\section{Discussion}

Large parts of Baltic Proper and Gulf of Finland are nitrogenlimited, resulting in excess phosphorus in the surface layer in late summer. This excess DIP pool has the potential to stimulate blooms of nitrogen-fixing cyanobacteria. That is, the potential of late summer bloom is determined as early as February by the excessive DIP concentration in the surface layer. This correspondence has been studied by Kahru et al. (2000). In later studies Janssen et al. (2004) have reached the same conclusion with the computational models and Lilover and Stips (2008) based on analysis of observations.

Our ensembles demonstrate the sensitivity of HABs to nutrient fields, especially phosphate. Similarities can be seen in the distribution of the computational initial phosphate field after the spring bloom at the end of May (Fig. 9b) and probability based forecast (Fig. 7a). The observed initial phosphate field (Fig. 9a) has similar high DIP concentrations in the Baltic Proper and western parts of Gulf of Finland, but concentrations in the Bothnian Sea are higher only in the initial winter DIP field.

The initial nutrient field plays an important role in algae growth and it appears at first that spatially the nutrient field is a more dominant factor in algal blooms than the weather conditions. However, during the summer the meteorological variables have a great impact on timing, duration and intensity of the blooms as can be seen in Fig. 3. For example Fig. 3b shows that unfavourable weather conditions can delay the cyanobacteria growth for weeks. It is also seen that the concentration of cyanobacteria chlorophyll is strongly dependent on weather conditions.
This dependance on weather conditions led Kahru et al. (2007) to suggest that only basin wide forecasts of frequency of cyanobacterial accumulations are useful. As this work deals with forecasting probability of blooms instead of bloom frequency and we use a circulation model with actual weather forecasts as inputs, it is possible that our approach is suitable on sub-basin scales. This notion would require further investigation, however.

The biological component of the model used in this study is a simplified yet robust representation of the diverse natural ecosystem, thus it has only three different algal groups and three different nutrients related to each other with relatively simple equations shown in Appendix A. However, the verification work of Kiiltomäki (2008) has showed that the biogeochemical component is fit for this kind of work. Furthermore, it has been shown in Section 3.1 that the model responds well to the changing weather conditions and the dynamics are accurate enough as the decrease in cyanobacterial concentration during the upwelling event is reproduced by the model. Furthermore, the benefit of a more complex biological component is not apparent because of other uncertainties such as the strong effect of the initial nutrient field. It would also require more computing time which is not an advantage for an operational model, especially when it comes to computationally demanding ensemble forecasts. Therefore it stands to reason for this purpose that it might be more useful to increase the accuracy of initial nutrient field and nutrient input than to further develop the relatively accurate biogeochemical component.

As the initial condition data was based on somewhat sparse wintertime observations it would be interesting to further investigate whether perturbating the initial nutrient conditions could enable the quantification of the resulting uncertainty in the forecasts. However, a perturbation scheme for marine biogeochemical forecasts remains to be developed. 

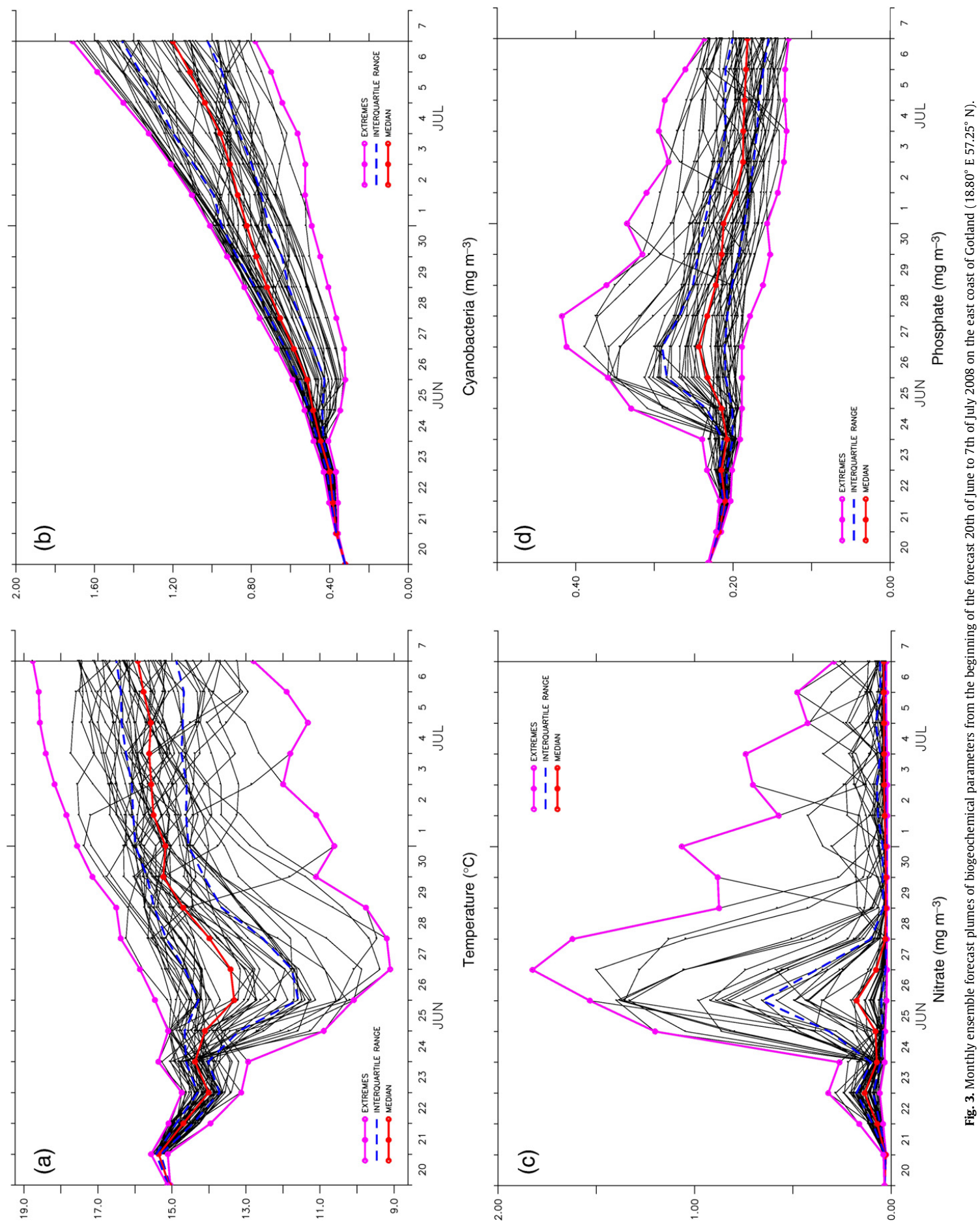


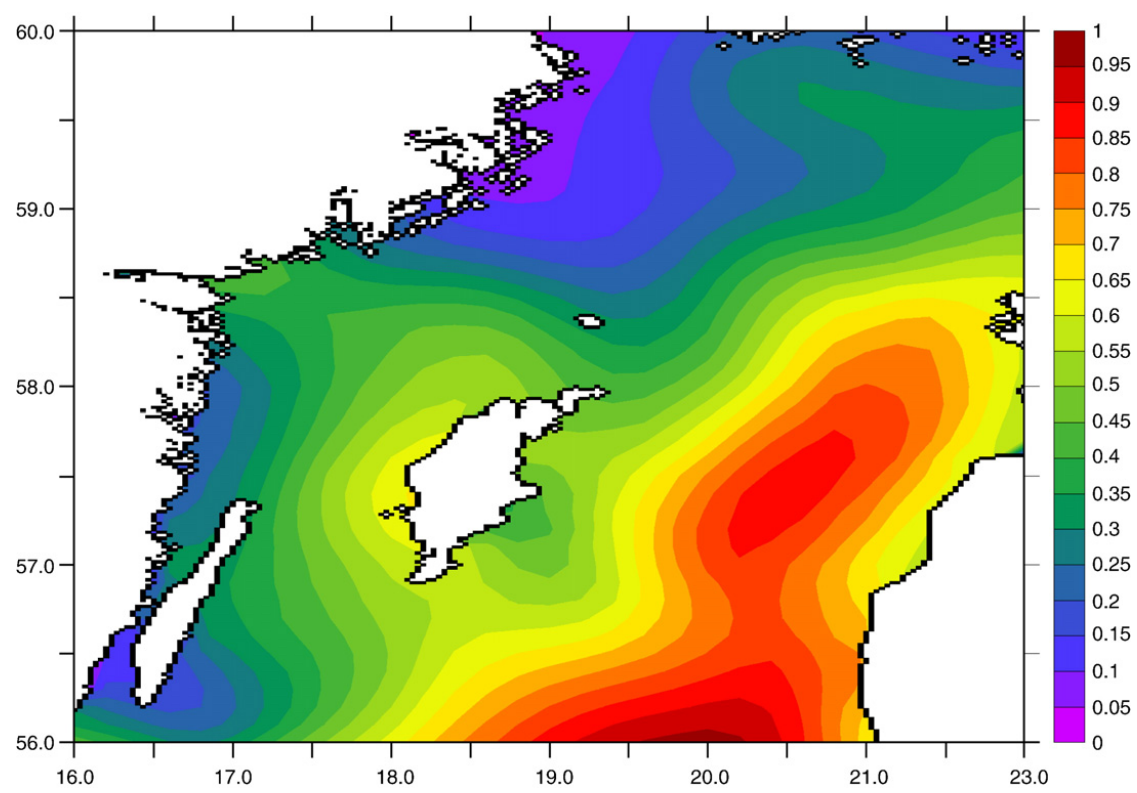

Fig. 4. Cyanobacterial ensemble mean forecast $\left(\mathrm{mg} \mathrm{m}^{-3}\right)$ for the 1 st of July from the run beginning from 20 th of June $(\eta=100)$. Lower concentrations on the coast of Gotland $\left(18.80^{\circ} \mathrm{E}\right.$ $57.25^{\circ} \mathrm{N}$ ) indicate upwelling.

\subsection{Applications}

Ensemble forecasts of the marine environment have a variety of possible applications.

Environmental indicators, derived quantities describing state of the environment in an understandable manner, provide information needed for decision makers to mitigate environmental problems. The range of decision makers varies from individual consumers to politicians, and the indicators should be helpful in making environmental decisions.

For several years computational models have been used as a decision support tool for policy makers. End users have found the

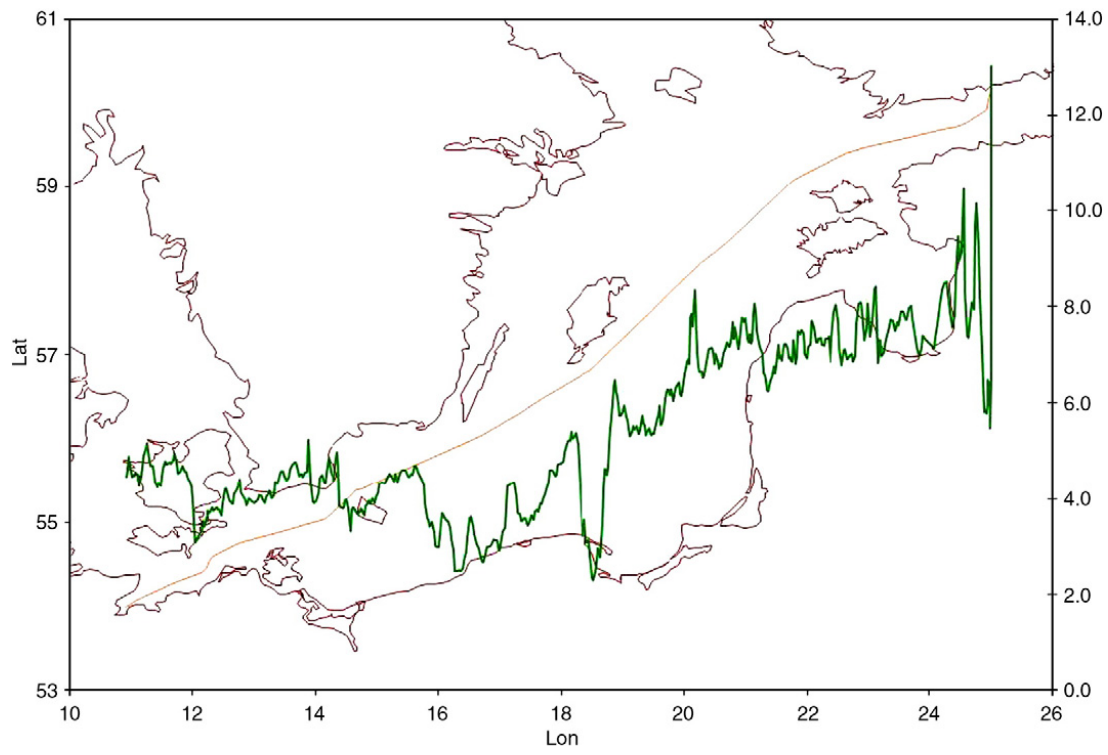

Fig. 5. Algaline fycocyanin (blue-green algal biomass) observations (PC fluorescence) on 1st and 2nd of July 2008 on the route from Helsinki to Travemünde. On the east coast of Gotland the values are clearly lower.

Courtesy: Finnish Institute of Marine Research 


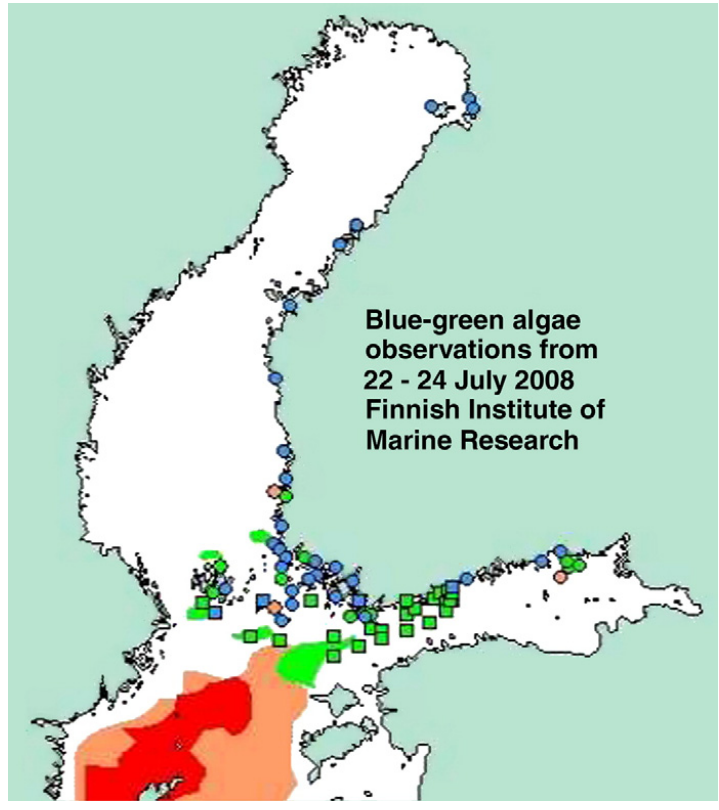

Fig. 6. Combined harmful algal bloom observations from 22nd to 24th of July 2008 . Red colour is for very abundant blooms, orange is for abundant blooms, green means there is some algae and blue that there is no algae. This composite picture is based on qualitative visual observations, there are no concentration data included.

\subsection{Carbon:nitrogen and Carbon:chlorophyll-a ratios}

Carbon:nitrogen:phosphorus stoichiometry is one of the most discussed topics in marine biogeochemistry and no final agreement on this relationship has yet been found. The most widely used ratio is so called Redfield ratio, $C: N: P=106: 16: 1$. There have been many studies on the subject and it has been pointed out by Arrigo (2005) that the Redfield ratio is more an average than a universal constant, and a single measurement, especially if made in a coastal region, can differ significantly from it. Because cyanobacteria are phosphorus limited in the Baltic Sea, as they can fix nitrogen, there is no need to take phosphorus into account in the chlorophyll-a conversion since the model treats algae as a nitrogen reservoir. As discussed in Section 2.3, we used $C: N$ ratio of 6.3 for chlorophyll-a conversions, which is slightly lower than Redfield's ratio which gives $C: N=106: 16=6.625$.

Although the carbon:nitrogen ratio has its effects on chlorophyll-a conversion, a more significant source of error is the carbon:chlorophylla ratio $\eta$. As illustrated in Fig. 7 the value of this ratio affects the results considerably. Because this ratio is so poorly constrained in this region it is hard to argue which of the forecasts shown would be the most proper one. Achieving a more accurate $C$ :Chla ratio would require information at least on the mean $\eta$ of cyanobacteria in the Baltic Sea. This could then be used as a best prior estimate and changed according to the state of the bloom, although another question is how the state of the bloom can be determined. Geider et al. (1997) have presented some modelling approaches that could be used to resolve this variability. However the determination of $\eta$ is not on the scope of our article, but we note the significance and uncertainty related to it.

The uncertainties in the nitrogen to chlorophyll-a conversion has its effects also on the accuracy of the forecast when verified against observations. Variation in conversion values adds uncertainties which could not be reproduced by this model setup. A biased conversion value will also cause bias to the results irrespective of actual model skill.

\subsection{Limiting value for $H A B s$}

In Section 2.3, we determined a chlorophyll-a concentration of $2 \mathrm{mg} \mathrm{m}^{-3}$ as a limit for a possible visible cyanobacterial occurrence (see Section 2.3) Defining such a limit, however, for cyanobacterial bloom is difficult due to the lack of standards and especially because most bloom observations are based on visual approximation. However there are some studies where measurements have been done during cyanobacterial blooming in the Baltic Sea area (Seppälä and Balode, 1999; Nausch et al., 2004; Kutser et al., 2006; Mazur-Marzec et al., 2006). Kutser et al. (2006) suggested that blooming can be defined as chlorophyll-a concentration exceeding $4 \mathrm{mg} \mathrm{m}^{-3}$. MazurMarzec et al. (2006) found that chlorophyll-a concentration was round $10 \mathrm{mg} \mathrm{m}^{-3}$ or more during blooming in Gulf of Gdańsk summer 2004. Therefore, taking into account the uncertainties in the nitrogen-chlorophyll conversion, $2 \mathrm{mg} \mathrm{m}^{-3}$ is a conservative limit for a level of biomass that could be perceived as a harmful or nuisance bloom.

\section{Conclusions}

Ensemble forecasting appears to be a promising tool in operational oceanography. The probability based approach illuminates the uncertainty of modelled phenomena. Stable conditions create more unanimous ensembles and vice versa.

Spring-time phosphorus fields are a relatively good predictor for the spatial, basin-scale distributions of HABs in the summer. The spatial variation of forecasted blooms is relatively small.

The weather conditions, however, clearly have an impact on timing, duration and intensity of HABs. This variation can be observed from and quantified with the ensemble forecasts in a manner that 

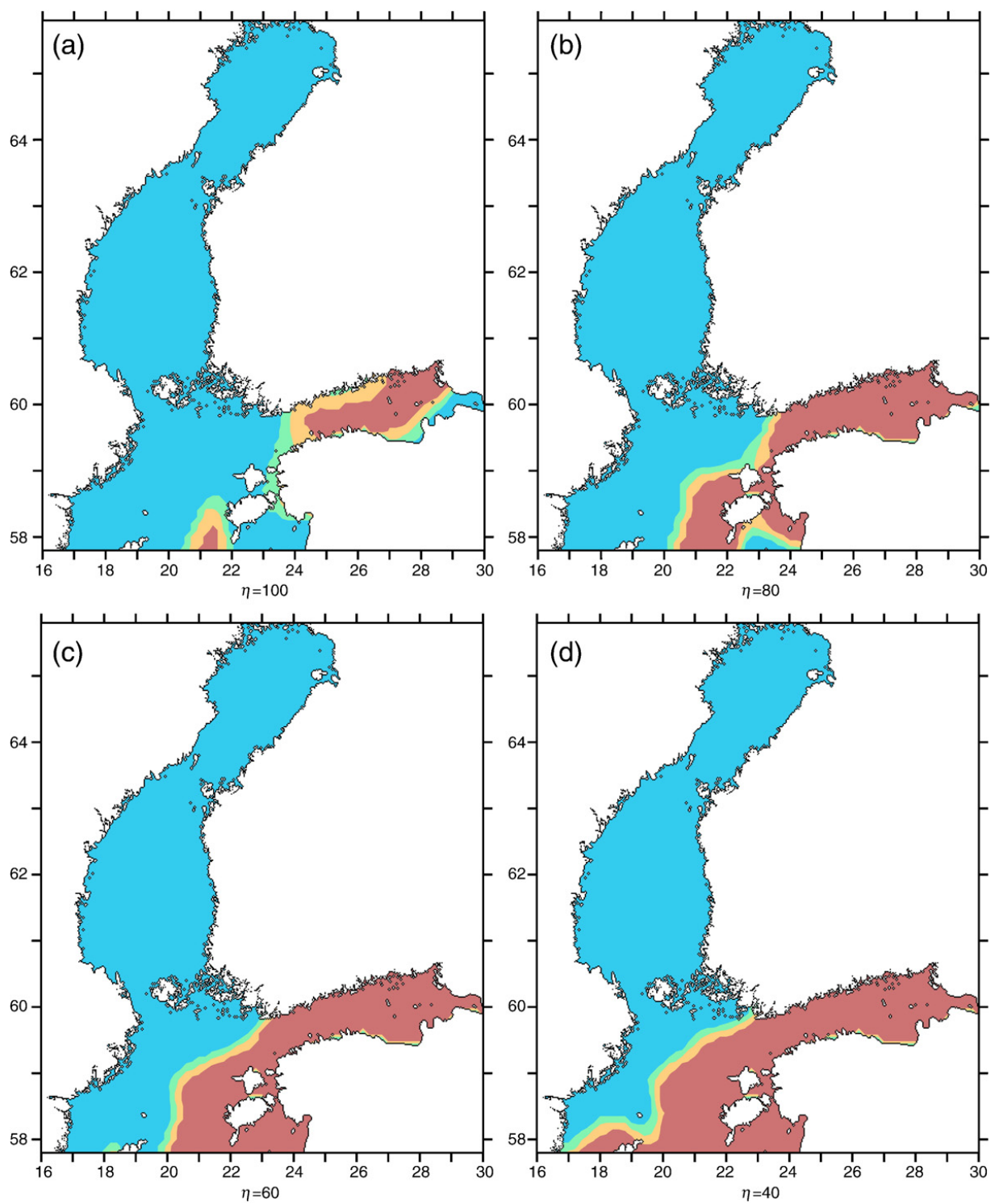

Fig. 7. Harmful algal concentration ensemble forecast with limiting value of $2 \mathrm{mg} \mathrm{m}^{-3}$ for blooming, with different values of C:Chla ratio (from 100 in 6 to 40 in 6 ). This two week harmful algal probability forecast was formed from an ensemble run starting from 10th of July (cf. Fig. 8). Red colour indicates high probability of blooms ( $>75 \%$ ) at the end of the forecast, yellow considerable probability (50\%-75\%), green moderate probability ( $25 \%-50 \%$ ) and blue low probability $(<25 \%)$. This harmful algal forecast depends among other things on the value chosen for C:Chla ratio $\eta$ as shown in Eq. (1). The forecast map changes notably with different values of $\eta$ ranging from 100 to 40.

supports pre-emptive actions, at least against exposure to adverse health effects.

When developing tools for marine policy making, the quality of the modelled results should be well known and the quantification of errors should be considered. Quantitative verification of the $\mathrm{HAB}$ ensemble forecasts, however, is very challenging because of the limited amount of observational data, and the difficulties in matching the observed variables with the predicted variables.
Both the model's sensitivity to initial conditions and the challenges faced with verification suggest that HAB modelling would greatly benefit from an increased amount of relevant observations. Verification would become much easier if quantitative information about biomass concentrations in the Baltic Sea during the summer was available. Gaps in the winter time phosphate monitoring measurements can lead to notable shortcomings in summer's bloom forecasts, and would need either more observations or a highly sophisticated 

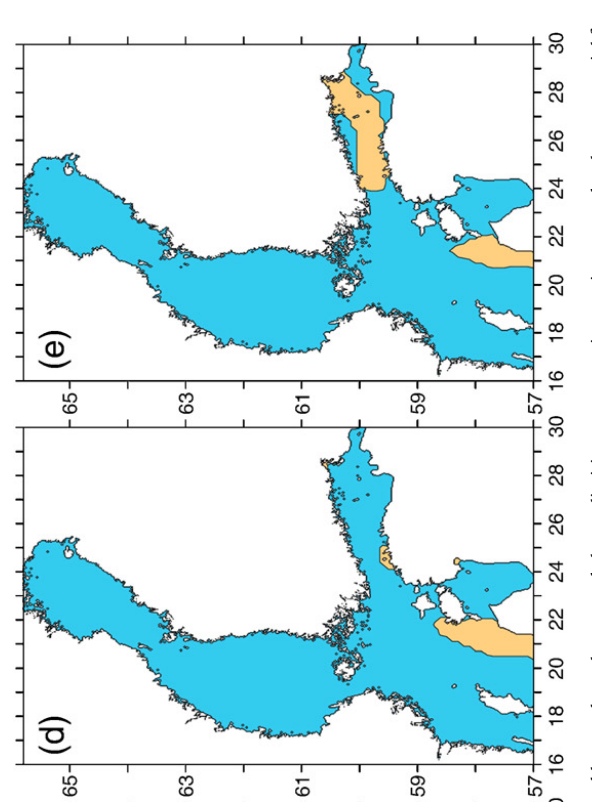

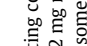

政

尊

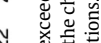

홀 ㅎ⿺ㅎ

品

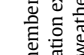

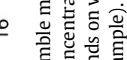
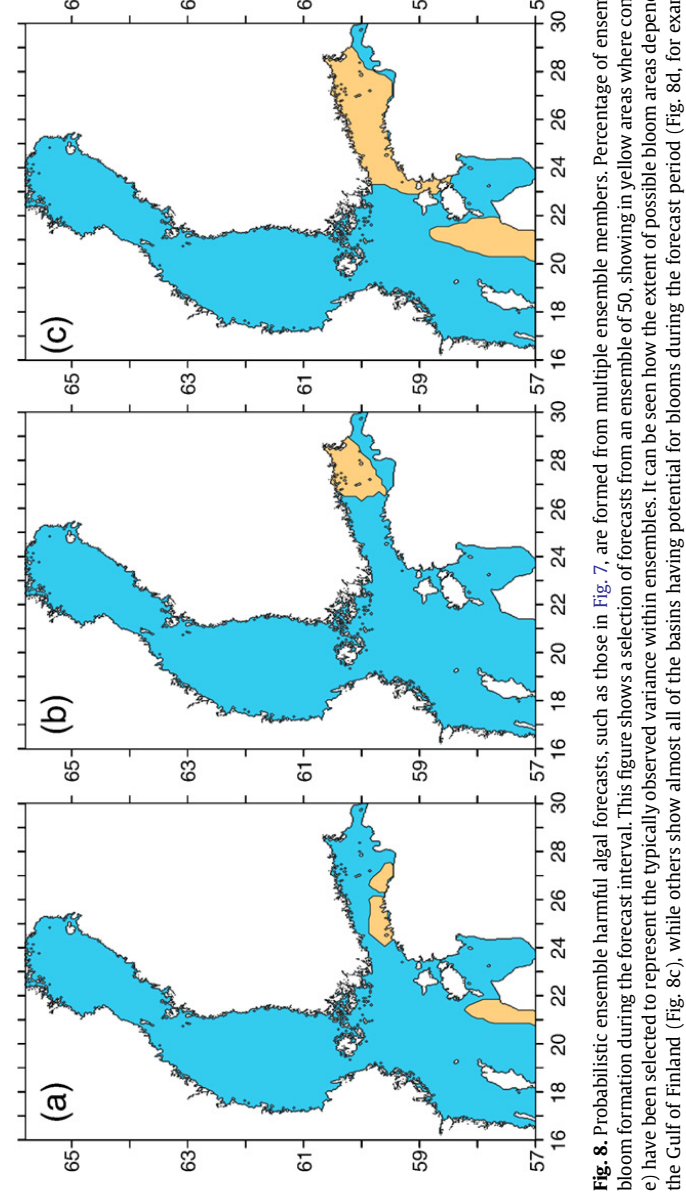


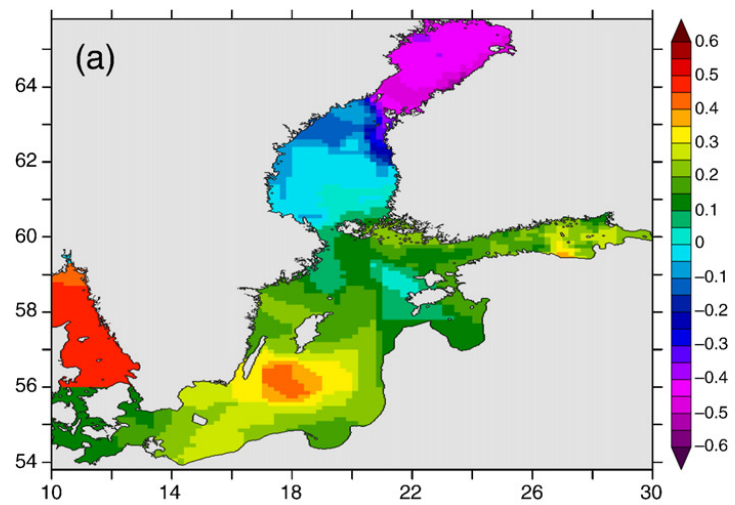

Initial observation based estimated excess phosphate field $\left(\mathrm{mg} \mathrm{m}^{-3}\right)$

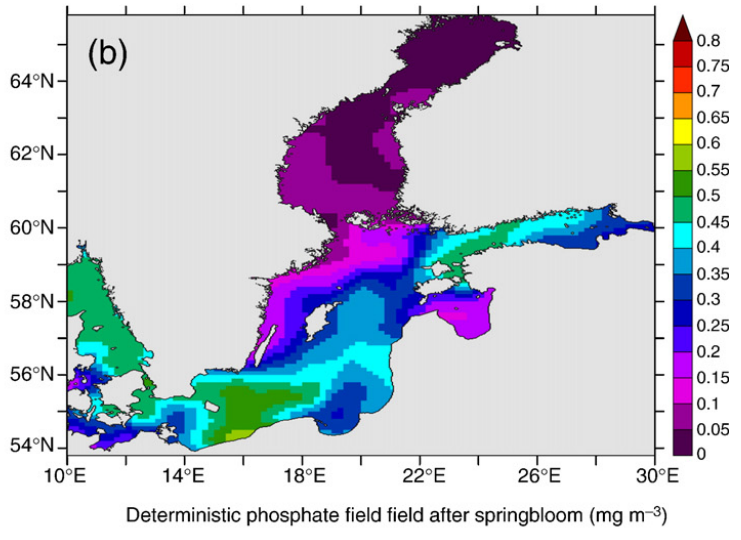

Deterministic phosphate field field after springbloom $\left(\mathrm{mg} \mathrm{m}^{-3}\right)$

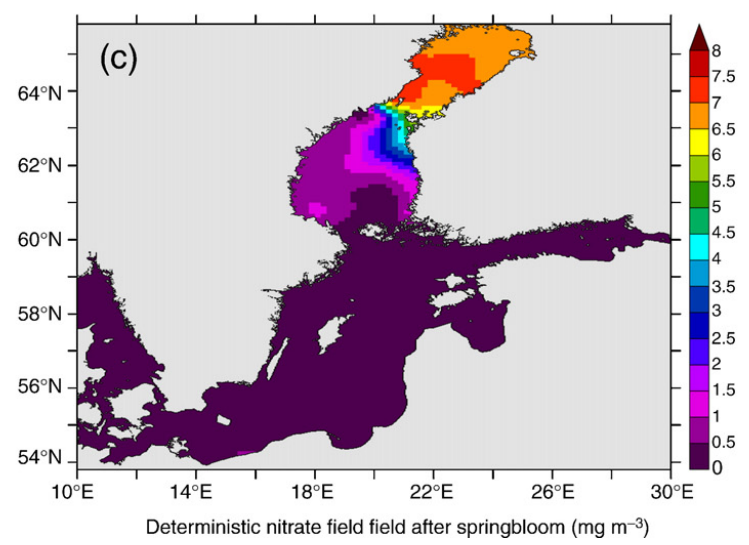

Fig. 9. Fig. 9a shows initial excess phosphate field (DIP-DIN/16) interpolated and estimated from nitrate and phosphate observations made by R/V Aranda in winter 2008. Fig. 9b shows phosphate after spring bloom in the end of May 2008. Field is computed from observed initial fields by deterministic model. Fig. $9 \mathrm{c}$ is as Fig. $9 \mathrm{~b}$ but for nitrate. We can see that spring bloom has depleted nitrate field in areas where cyanobacterial blooms typically occur. Therefore Fig. $9 \mathrm{~b}$ can in this context be interpreted as a more complex, model generated estimate of the simple calculation shown in Fig. 9a.

assimilation scheme to fill. Should these kind of measurements and better assimilation schemes become available, we expect the benefits of the ensemble approach to become even more pronounced.

\section{Acknowledgements}

This work has been partly financed by the EU Commission 6th framework project ECOOP European COastal-shelf sea OPerational Observing and forecasting system (contract number 036355). We thank also the Algaline project for making the ferrybox data available. We would also like to thank our colleague Letizia Tedesco for her valuable comments.

\section{Appendix A. Ecological equations}

The equations in the ecological model are

$$
\begin{aligned}
& \frac{\partial c_{d}}{\partial t}=c_{d}\left(\mu_{d}-e_{d}-m_{d} c_{d}\right) \\
& \frac{\partial c_{f}}{\partial t}=c_{f}\left(\mu_{f}-e_{f}-m_{f} c_{f}\right)
\end{aligned}
$$

$\frac{\partial c_{c}}{\partial t}=c_{c}\left(\mu_{c}-e_{c}-m_{c} c_{c}\right)$

$\frac{\partial c_{N}}{\partial t}=-c_{d}\left(\mu_{d}-e_{d}\right)-c_{f}\left(\mu_{f}-e_{f}\right)-c_{c}\left(-e_{c}\right)$

$\frac{\partial c_{P}}{\partial t}=r_{P N}\left(-c_{d}\left(\mu_{d}-e_{d}\right)-c_{f}\left(\mu_{f}-e_{f}\right)-c_{c}\left(\mu_{c}-e_{c}\right)\right)$

$\frac{\partial c_{S}}{\partial t}=r_{S N}\left(-c_{d}\left(\mu_{d}-e_{d}\right)\right)$

where $c_{d}, c_{f}$ and $c_{c}$ are the biomasses of diatoms, flagellate and cyanobacteria, respectively. Concentrations of nitrogen, phosphate and silicate are $c_{N}, c_{P}$ and $c_{S}$. The constant ratios for cyanobacteria nutrient intake are $r_{P N}$ and $r_{S N}$. Mortality rates are $m_{d}, m_{f}$ and $m_{c}$. The specific rates of exudations are dependent exponentially on temperature by equation $e_{d f, c}=e_{0^{2}}^{a}$.

The phytoplankton growth rates $\mu_{d, f, c}$ depend on nutrient concentrations, irradiation and temperature:

$\mu_{f_{\max }}=\mu_{f 0} a^{d T}$ 
$\mu_{f}=\mu_{f_{\max }} \frac{I}{I+k_{f l}}\left(\frac{c_{P}}{c_{P}+k_{f P}} \frac{c_{N}}{c_{N}+k_{f N}}\right)$,

where $I=I(z)$ is the illumination, $\mu_{f 0}$ is the maximum growth rate at $0{ }^{\circ} \mathrm{C} . k_{f P, f N}=\mu_{f, \alpha} / \alpha_{f N, f P}$ are the half saturation functions as used by Aksnes et al. (1995) with constant but species and limitation dependent affinities $\alpha . I(z)$ depends on the amount of biomass between the depth $z$ and the surface (shelf-shading).

\section{References}

Aksnes, D.L., Ulvestad, K.B., Balio, B.M., Berntsen, J., Egge, J.K., Svendsen, E., 1995. Ecological modelling in coastal waters: towards predictive physical-chemical-biological simulation models. Ophelia 41, 5-36.

Arrigo, K., 2005. Marine microorganisms and global nutrient cycles. Nature 437 (7057), 349-355.

Boyer, T., Antonov, J., Garcia, H., Johnson, D., Locarnini, R., Mishonov, A., Pitcher, M., Baranova, O., Smolyar, I., 2006. World Ocean Database 2005. NOAA Atlas NESDIS 60 U.S Government Printing Office, Washington D.C. version WOD 2001.

Brankovic, C., Palmer, T.N., 1997. Atmospheric seasonal predictability and estimates of ensemble size. Monthly Weather Review 125, 859-874.

Buizza, R., 1997. Potential forecast skill of ensemble prediction and spread and skil distributions of the ECMWF ensemble prediction system. Monthly Weather Review 125, 99-119.

Eker-Develi, E., Berthon, J.-F., van der Linde, D., 2008. Phytoplankton class determination by microscopic and HPLC-CHEMTAX analyses in the southern Baltic Sea. Marine Ecology Progress Series 359, 69-87.

Engström-Öst, J., Koski, M., Schmidt, K., Viitasalo, M., Jonasdottir, S.H., Kokkonen, M. Repka, S., Sivonen, K., 2002. Effects of toxic cyanobacteria on a plankton assemblage: community development during decay of Nodularia spumigena. Marine Ecology Progress Series 232, 1-14.

FIMR, SYKE, 2006. Moderate algal blooms are forecast for the western Gulf of Finland and southern Archipelago Sea stronger blue-green algal blooms are expected in the central and southern parts of the Baltic Sea. http://www.itameriportaali.fi/en/ ajankohtaista/uutisia_muualta/2006/en_GB/1143.

Geider, R.J., MacIntyre, H.L., Kana, T.M., 1997. Dynamic model of phytoplankton growth and acclimation: responses of the balanced growth rate and the chlorophyll a: carbon ratio to light, nutrient-limitation and temperature. Marine Ecology Progress Series $148,15-25$.

Gill, A.E., 1982. Atmosphere-Ocean Dynamics. Vol. 30 of International Geophysics. Academic Press, San Diego, USA.

HELCOM, 2009. Activities 2008 - overview. No. 118 in Baltic Sea Environment Proceedings. Helsinki Comission (HELCOM) - Baltic Marine Environment Protection Commission.

Janssen, F., Neumann, T., Schmidt, M., 2004. Inter-annual variability in cyanobacterial blooms in the Baltic Sea controlled by wintertime hydrographic conditions. Marine Ecology Progress Series 275, 59-68.

Kahru, M., Leppänen, J.M., Rud, O., Savchuk, O.P., 2000. Cyanobacteria blooms in the Gulf of Finland triggered by saltwater inflow into the Baltic Sea. Marine Ecology Progress Series 207, 1318

Kahru, M., Savchuck, O.P., Elmgren, R., 2007. Satellite measurements of cyanobacterial bloom frequency in the Baltic Sea: internannual and spatial variability. Marine Ecology Progress Series 343, 1523.
Kiiltomäki, A., 2008. Development of the Baltic Sea indicator report by Algline measurements and BalEco model results. Master's thesis, University of Helsinki.

Kutser, T., Metsamaa, L., Strömbeck, N., Vahtmäe, E., 2006. Monitoring cyanobacteria blooms by satellite remote sensing. Estuarine, Coastal and Shelf Science 67, 303-312.

Lermusiaux, P.F.J., 2006. Uncertainty estimation and prediction for interdisciplinary ocean dynamics. Journal of Computational Physics 217, 176-199.

Leutbecher, M., Palmer, T., 2008. Ensemble forecasting. Journal of Computational Physics 227, 3515-3539.

Lilover, M.-J., Stips, A., 2008. The variability of parameters controlling the cyanobacteria bloom biomass in the Baltic Sea. Journal of Marine Systems 74, S108-S115.

Marshall, J., Adcroft, A., Hill, C., Perelman, L., Heisey, C., 1997a. A finite-volume incompressible Navier Stokes model for studies of the ocean on parallel computers. Journal of Geophysical Research 102 (C3), 5753-5766.

Marshall, J., Hill, C., Perelman, L., Adcroft, A., 1997b. Hydrostatic, quasi-hydrostatic, and nonhydrostatic ocean modeling. Journal of Geophysical Research 102 (C3), 5733-5752.

Mazur-Marzec, H., Krel, A., Kobos, J., Pliski, M., 2006. Toxic nodularia spumigena blooms in the coastal waters of the Gulf of Gdansk: a ten-year survey. Oceanologia 48, 255-273.

Molteni, F., Buizza, R., Palmer, T., Petroliagis, T., 1996. The ECMWF ensemble prediction system: methodology and validation. Quarterly Journal Royal Meteorological Society 122, 73-119.

Nausch, M., Nausch, G., Wasmund, N., 2004. Phosphorus dynamics during the transition from nitrogen to phosphate limitation in the central Baltic Sea. Marine Ecology Progress Series 266, 15-25.

Nausch, M., Nausch, G., Lass, H.S., Mohrholz, V., Nagel, K., Siegel, H., Wasmund, N., 2009. Phosphorus input by upwelling in the eastern Gotland Basin (Baltic Sea) in summer and its effects on filamentous cyanobacteria. Estuarine, Coastal and Shelf Science 83, 434-442.

Niemi, A., 1979. Blue-green algal blooms and N:P ratio in the Baltic Sea. Acta Botanica Fennica 110, 57-61.

Niemistö, L., Rinne, I., T., M., Niemi, Å., 1989. Blue-green algae and their nitrogen fixation in the Baltic Sea. Finnish Marine Research 17, 3-20.

Redfield, A.C., 1958. The biological control of chemical factors in the environment. American Scientist 205.

Richardson, D.S., 2000. Skill and relative value of the ensemble prediction system. Quarterly Journal Royal Meteorological Society 126, 649-667.

Ruokanen, L., Kaitala, S., Fleming, V., Maunula, P., 2003. Alg@line-joint operationa unattended phytoplankton monitoring in the Baltic Sea. In: Dahlin, H., Flemming, N.C. Nxcvxc, K. Petersson, S. (Eds.), Building the European Capacity in Operational Oceanography, Proceedings of the Third International Conference on EuroGOOS. Elsevier Oceanography Series, vol. 69. Elsevier, pp. 519-522. http://dx.doi.org/10.1016/S04229894(03)80083-1.

Seifert, T., Kayser, B., 1995. A high resolution spherical grid topography of the Baltic Sea. Meereswissenschaftliche Berichte 9, 72-88.

Seppälä, J., Balode, M., 1999. Spatial distribution of phytoplankton in the Gulf of Riga during spring and summer stages. Journal of Marine Systems 23 (1), 51-67.

Stipa, T., Skogen, M., Sehested Hansen, I., Eriksen, A., Hense, I., Kiiltomäki, A., Søiland, H. Westerlund, A., 2003. Short-term effects of nutrient reductions in the North Sea and the Baltic Sea as seen by an ensemble of numerical models. Meri - Report Series of the Finnish Institute of Marine Research 49, 43-70.

Talagrand, O., Vautard, R., Strauss, B., 1999. Evaluation of probabilistic prediction systems. Proceedings of the ECMWFWorkshop on Predictability, 20.-22. October 1997. ECMWF, Shienfield Park, Reading.

Tyrrell, T., 1999. The relative influences of nitrogen and phosphorus on ocean primary production. Nature $400,525-531$.

Walve, J., Larsson, U., 2007. Blooms of Baltic Sea aphanizomenon sp. (cyanobacteria) collapse after internal phosphorus depletion. Aquatic Microbial Ecology 49, 57-69. 


Finnish Meteorological Institute

Erik Palménin aukio 1

P.O. Box 503

FI-00560 HELSINKI

tel. +358295391000

WWW.FMI.FI

Finnish Meteorological Institute CONTRIBUTIONS No. 157

ISSN 0782-6117

ISBN 978-952-336-088-4 (paperback)

ISBN 978-952-336-089-1 (pdf)

https://doi.org/10.35614/isbn.9789523360891

$\because 8$

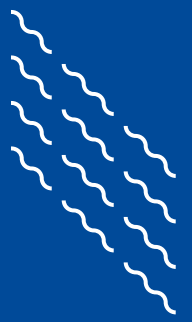

